\title{
ॠUSGS
}

\section{U.S. Geological Survey-Energy and Wildlife Research Annual Report for 2017}
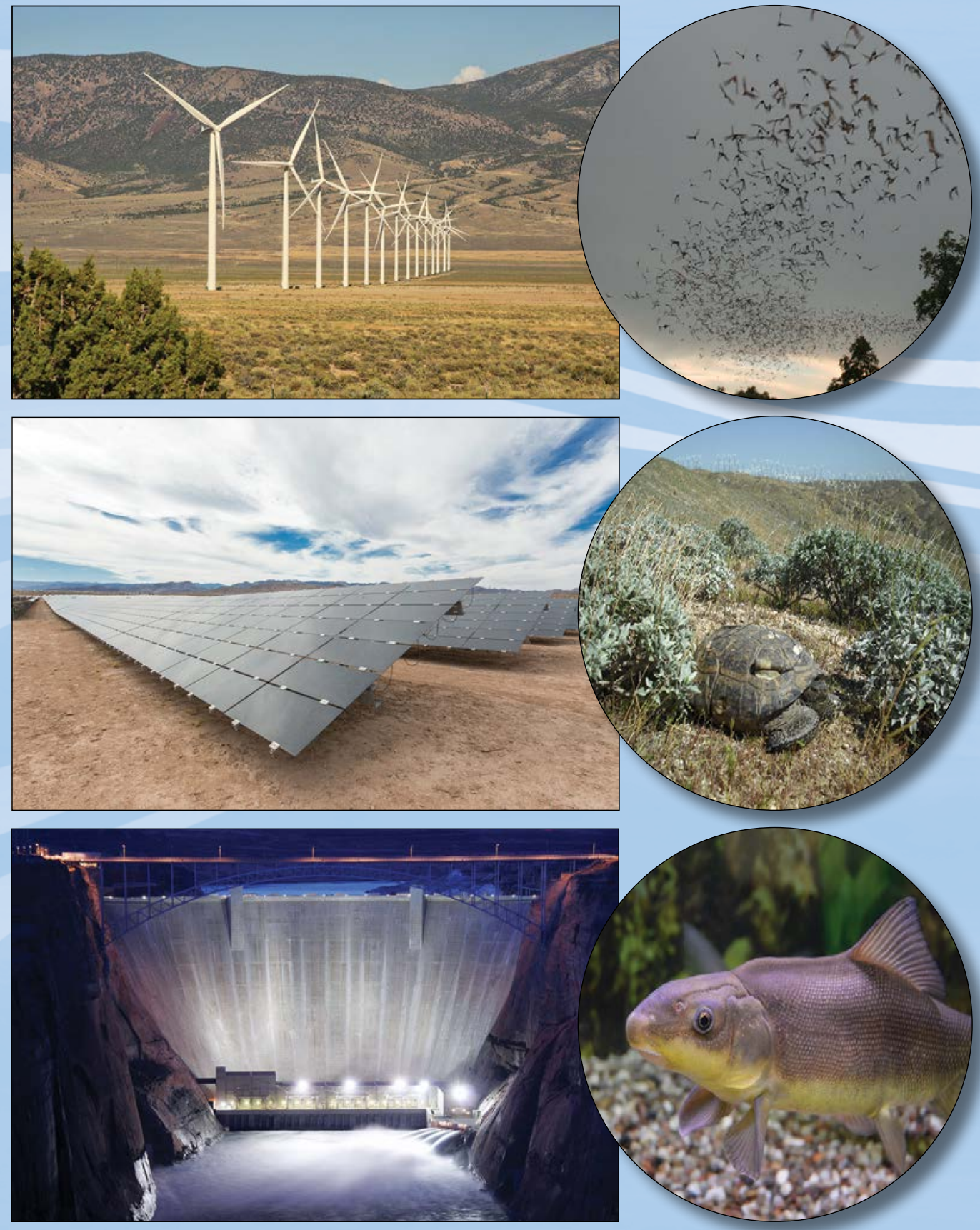

Circular 1435

\section{U.S. Department of the Interior}

U.S. Geological Survey 
Cover. Top: Wind energy facility in White Pine County, Nevada (Alan M. Cressler, U.S. Geological Survey [USGS]), and bats flying at night (Ann Froschaue, U.S. Fish and Wildlife Service). Middle: Utility-scale solar array on Moapa Band of Paiutes Indian land, southern Nevada (U.S. Department of Energy), and desert tortoise near Palm Springs, California (Jeffrey Lovich, USGS). Bottom: Glen Canyon Dam hydroelectric facility at night, Arizona (Thomas Ross Reeve, Bureau of Reclamation), and razorback sucker (Melanie Fischer, U.S. Fish and Wildlife Service). 


\section{U.S. Geological Survey-Energy and Wildlife Research Annual Report for 2017}

Edited by Mona Khalil

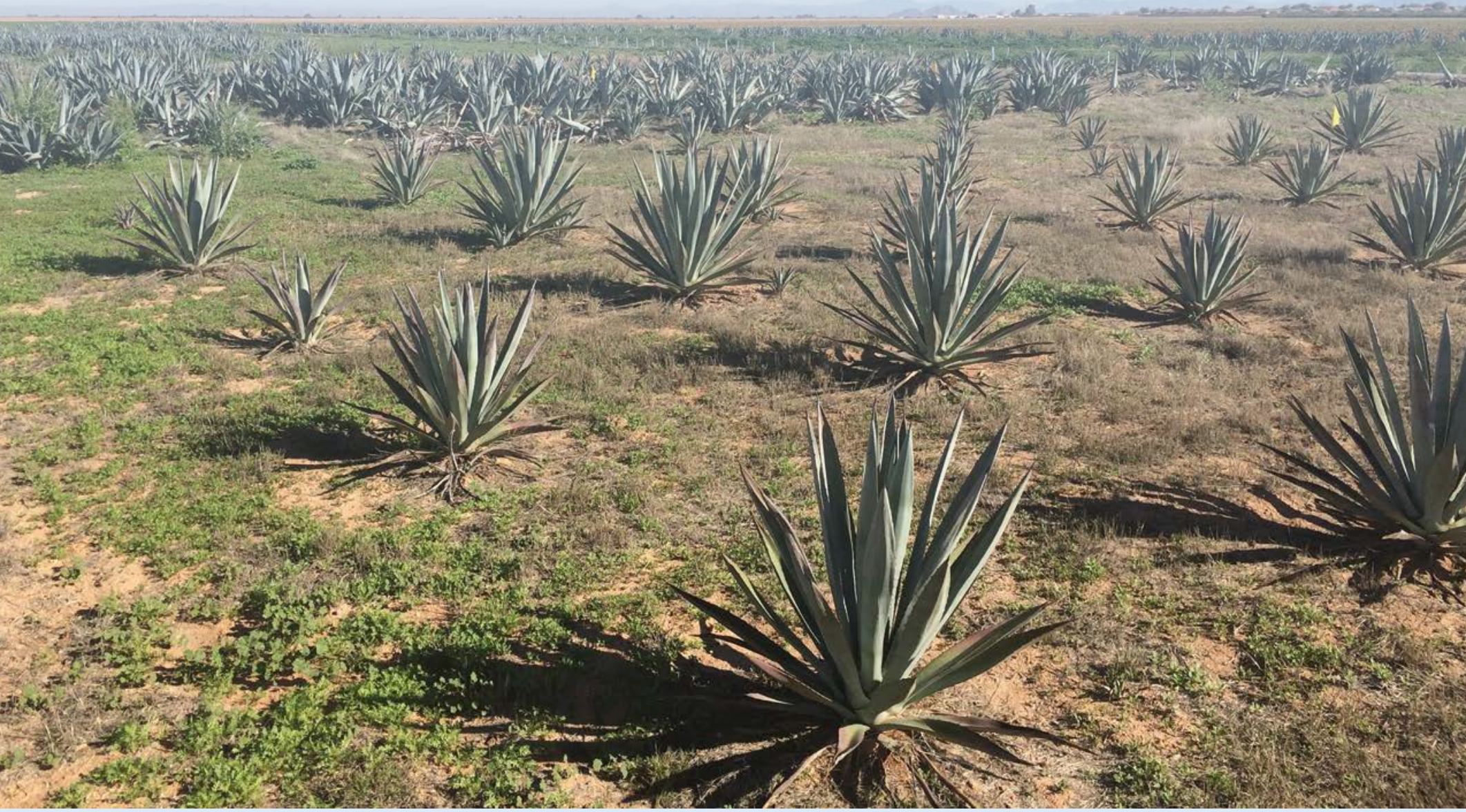

Agave plants at a U.S. Department of Agriculture experimental plot site near Phoenix, Arizona. The U.S. Geological

Survey, in collaboration with the U.S. Department of Agriculture Arid Land Agricultural Research Center and Ohio University, is conducting tests for the potential production of agave biofuel. Photograph by Sasha Reed, U.S. Geological Survey.

Circular 1435 


\title{
U.S. Department of the Interior \\ RYAN K. ZINKE, Secretary
}

\section{U.S. Geological Survey William H. Werkheiser, Acting Director}

\author{
U.S. Geological Survey, Reston, Virginia: 2017
}

For more information on the USGS - the Federal source for science about the Earth, its natural and living resources, natural hazards, and the environment—visit https://www.usgs.gov/ or call 1-888-ASK-USGS.

For an overview of USGS information products, including maps, imagery, and publications, visit https://store.usgs.gov.

Any use of trade, firm, or product names is for descriptive purposes only and does not imply endorsement by the U.S. Government.

Although this information product, for the most part, is in the public domain, it also may contain copyrighted materials as noted in the text. Permission to reproduce copyrighted items must be secured from the copyright owner.

Suggested citation:

Khalil, Mona, ed., 2017, U.S. Geological Survey-Energy and wildlife research annual report for 2017: U.S. Geological Survey Circular 1435, 91 p., https://doi.org/10.3133/cir1435.

ISSN 1067-084X (print)

ISSN 2330-5703 (online)

ISBN 978-1-4113-4169-2 


\section{Contents}

Science to Understand Risks, Measure Impacts, and Inform Solutions..........................................

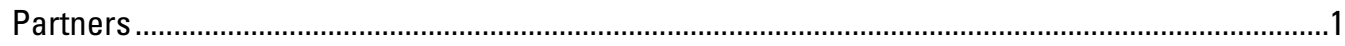

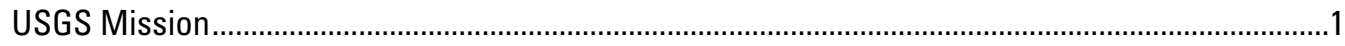

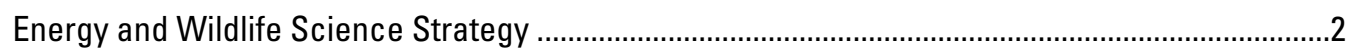

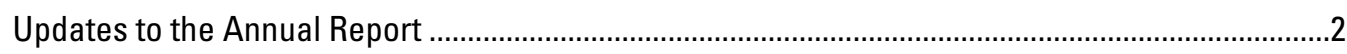

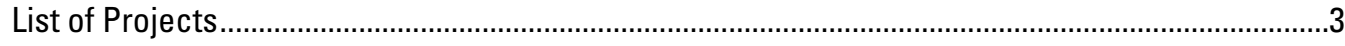

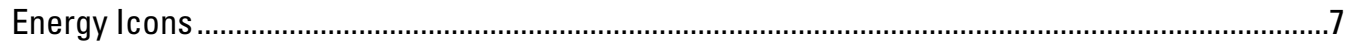

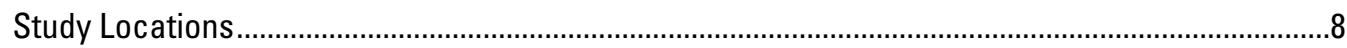

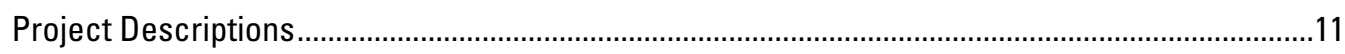

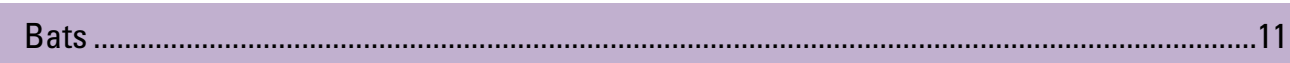

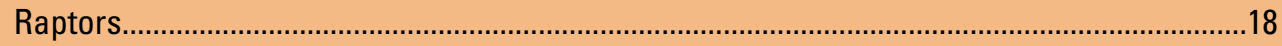

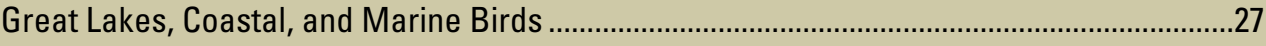

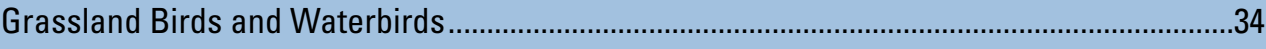

Alaska Marine and Avian Species..........................................................................................42

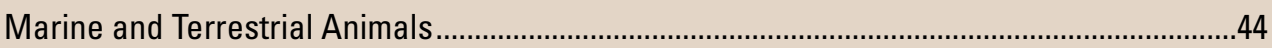

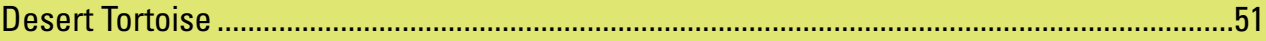

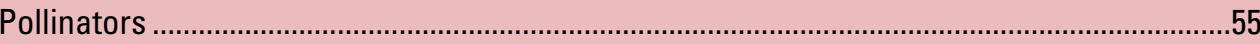

Fish and Other Aquatic Species ............................................................................................

Wildlife Habitats and Ecosystem Functions .........................................................................

Conservation and Energy Development Planning Tools............................................................77

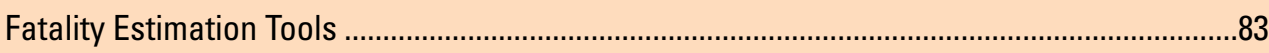

Risk Assessment and Management Support Tools................................................................. 85

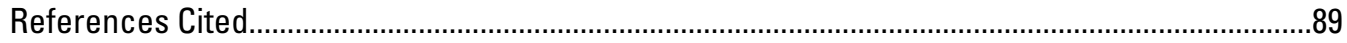

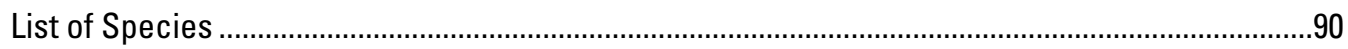




\section{Abbreviations}

\begin{tabular}{|c|c|}
\hline$A B R$ & auditory brainstem response \\
\hline AEA & Alaska Energy Authority \\
\hline $\mathrm{BCl}$ & Bat Conservation International \\
\hline BLM & Bureau of Land Management \\
\hline BOEM & Bureau of Ocean Energy Management \\
\hline BOR & Bureau of Reclamation \\
\hline BSEE & Bureau of Safety and Environmental Enforcement \\
\hline CRM & Collision Risk Model \\
\hline DART & disturbance automated reference toolset \\
\hline DNA & deoxyribonucleic acid \\
\hline DOE & U.S. Department of Energy \\
\hline DOI & U.S. Department of the Interior \\
\hline DRECP & Desert Renewable Energy Conservation Plan \\
\hline EIA & U.S. Energy Information Administration \\
\hline ESA & Endangered Species Act \\
\hline FAA & Federal Aviation Administration \\
\hline FSC & floating surface collector \\
\hline GIS & geographic information system \\
\hline GOM & Gulf of Mexico \\
\hline GoMMAPPS & Gulf of Mexico Marine Assessment Program for Protected Species \\
\hline GPS-GSM & Global Positioning System-Global System for Mobile Communications \\
\hline NABat & North American Bat Monitoring Program \\
\hline NMFS & U.S. National Marine Fisheries Service \\
\hline NOAA & National Oceanic and Atmospheric Administration \\
\hline NPS & National Park Service \\
\hline OCS & Outer Continental Shelf \\
\hline PacOCS & Pacific Outer Continental Shelf \\
\hline PCR & polymerase chain reaction \\
\hline PPR & Prairie Pothole Region \\
\hline SCB & Southern California Bight \\
\hline UOG & unconventional oil and gas \\
\hline URTD & upper respiratory tract disease \\
\hline USACE & U.S. Army Corps of Engineers \\
\hline USDA & U.S. Department of Agriculture \\
\hline USFWS & U.S. Fish and Wildlife Service \\
\hline USGS & U.S. Geological Survey \\
\hline UV & ultraviolet \\
\hline WEC & wave energy conversion \\
\hline WLCI & Wyoming Landscape Conservation Initiative \\
\hline WNS & white-nose syndrome \\
\hline
\end{tabular}




\title{
U.S. Geological Survey-Energy and Wildlife Research Annual Report for 2017
}

\author{
Edited by Mona Khalil
}

\section{Science to Understand Risks, Measure Impacts, and Inform Solutions}

Terrestrial and aquatic ecosystems provide valuable services to humans and are a source of clean water, energy, raw materials, and productive soils. The Nation's food supply is more secure because of wildlife. For example, native pollinators enhance agricultural crops, and insect-eating bats provide pest control services worth billions of dollars to farmers annually. Fish and wildlife are also vital to a vibrant outdoor recreation and tourism industry. Recreational activities, such as hunting, shooting, boating, and angling, generated $\$ 1.1$ billion in excise taxes paid to State wildlife agencies in 2017. National parks, wildlife refuges, and monuments accounted for $\$ 35$ billion in economic output and 318,000 jobs nationwide in 2016 (Cullinane and Koontz, 2017). Additional economic benefits are generated from the use and enjoyment of wildlife in State-owned lands and waters.

Although the United States is rich in natural resources, human activity continues to place new pressures on fish and wildlife and the habitats they rely on. The United States became the world's top producer of petroleum and natural gas products in 2012, surpassing Russia's natural gas production levels in 2009 and Saudi Arabia's petroleum production in 2013 (U.S. EIA, 2017a). The U.S. Energy Information Administration projects that the demand for liquid fuel, natural gas, and renewable energy will show strong growth in the next 20 years (U.S. EIA, 2016). Wind energy has demonstrated consistent growth since 2007 with now more than 53,000 wind turbines contributing to power grids in 41 States, Guam, and Puerto Rico (American Wind Energy Association, 2017). Solar energy has seen rapid growth since 2013 and made up nearly one-third of the total electricity generation additions in 2016 (U.S. EIA, 2017b). Yet as our Nation works to advance energy security and sustain wildlife, some conflicts have surfaced. Impacts of an expanding energy infrastructure include fragmentation and loss of habitat as well as mortality of birds, bats, fish, and other animals from interactions with energy

\section{USGS Mission}

The USGS provides science about the natural hazards that threaten lives and livelihoods; the water, energy, minerals, and other natural resources we rely on; the health of our ecosystems and environment; and the impacts of climate and land-use change. USGS scientists work to develop new methods and tools to supply timely, relevant, and useful information about the Earth and its processes.

generation facilities. Because energy development can often occur in wildlife habitats, ecological science can help guide project siting and operational decisions to areas that present the lowest risk to wildlife and energy developers.

To address these challenges and make the most of new opportunities, the U.S. Geological Survey (USGS) is producing innovative science to develop workable solutions that can help sustain wildlife and the habitat they rely upon, while allowing informed development.

\section{Partners}

To meet the Nation's most pressing science needs and deliver timely and relevant information related to energy development and wildlife, USGS scientists work with other Federal, State, and local government agencies; Tribal nations; academic institutions; and nongovernmental and private organizations. Partners include more than 20 Federal agencies, 25 State agencies, 5 Tribal Nations and Commissions, 20 nongovernmental organizations, 10 industry partners, and more than 50 academic institutions. 


\section{Energy and Wildlife Science Strategy}

USGS scientists provide information and science-based options that land and resource managers and private industries can use to make decisions regarding allowing access to energy resources while protecting the health of ecosystems and environments. This information can be used to avoid, minimize, or mitigate the impacts of energy infrastructure on fish and wildlife. This information can also inform areas where development may be best suited on the basis of merging economic, social, and ecological information. Research goals range from identification of a specific local issue, and options for management, to development of tools or techniques to address nationwide concerns. This science furthers our understanding of impacts and creates workable solutions. The three goals guiding activities concerning the investigation of wildlife and energy development are:

- Understand risks by identifying when, where, and how fish and wildlife share space with energy facilities

- Measure direct and indirect impacts to species

- Inform feasible and cost-effective solutions to minimize impacts through technological fixes, management, and mitigation

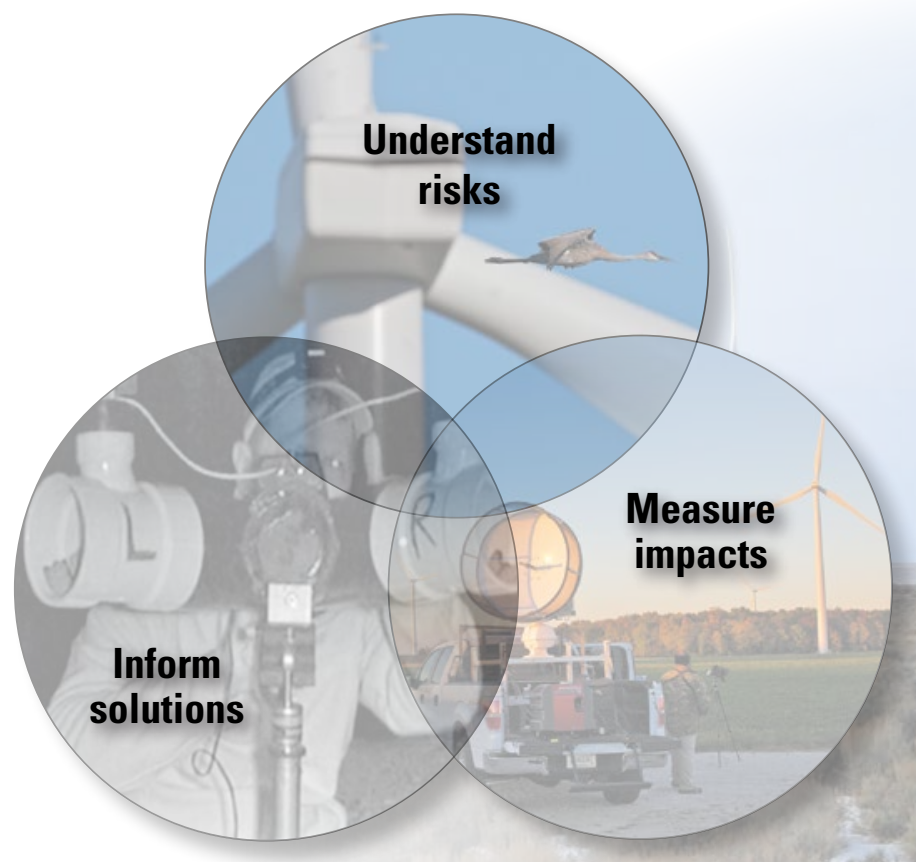

\section{Updates to the Annual Report}

This year's report features ongoing projects and new publications on energy development impacts and solutions for addressing risks to birds, bats, and other animals. We have updated the sections on bats, birds, desert tortoise, pollinators, and impacts to fish and wildlife habitats with new projects and publications. The report has an expanded section featuring science related to the management of hydropower effects on fish and aquatic resources, describing studies based in multiple regions, including the Pacific Northwest, the Northeast, the Southwest, and the mid-Atlantic regions. A new section listing projects focused on wildlife and energy development issues in Alaska has also been added. In the "Conservation and Energy Development Planning Tools" section, we feature science-based tools and approaches to assist resource managers in prioritizing areas for future energy development and for improving existing strategies for restoration following development. The final two sections focus on methods for fatality estimation, risk assessment, and other management support tools.

Figure 1. Three interrelated goals guiding USGS science in addressing energy and wildlife. 


\section{List of Projects}

Regulatory and management issues associated with energy development are often focused on the impacts on legally protected species and (or) other species and habitats of concern. The USGS science efforts highlighted in this report are organized by species or groups of species, habitats, and other topics considered most relevant to the U.S. Fish and Wildlife Service (USFWS), Bureau of Land Management (BLM), Bureau of Ocean Energy Management (BOEM), and other Federal and State agencies responsible for permitting energy projects, conserving or managing species and habitats, and monitoring operations of renewable or conventional energy facilities.

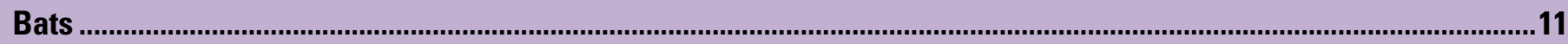

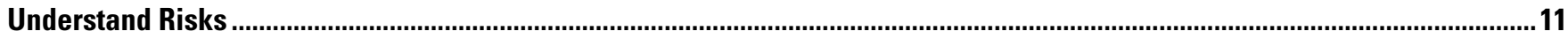

1. Understanding and Reducing Bat Fatalities Associated With Wind Turbines ..................................................................11

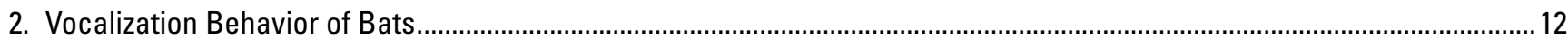

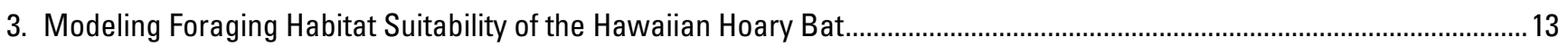

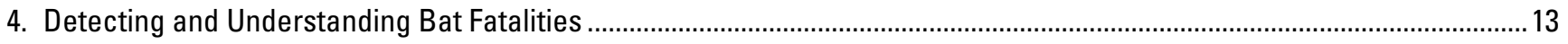

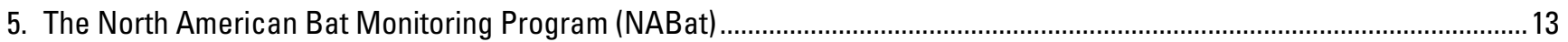

6. Pre- and Post-Hibernation and Migratory Activity of Bats in the Central Appalachians ....................................................... 14

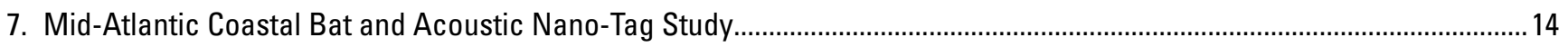

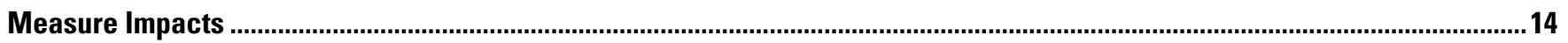

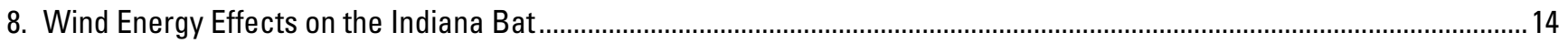

9. Using Genetic Tools to Examine the Biology of Summer-Roosting Indiana Bats............................................................ 15

10. Post-White-Nose Syndrome Assessment of Bat Distribution in the Mid-Atlantic and Northeast .........................................15

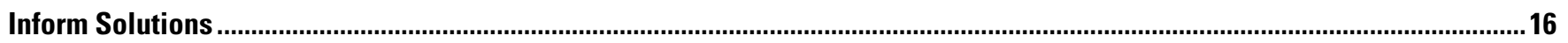

11. Ultraviolet Illumination as a Means of Reducing Bat Activity and Risk at Wind Turbines .................................................. 16

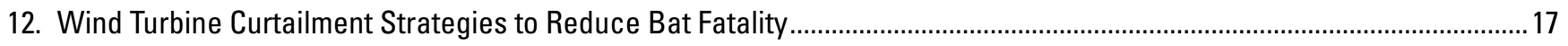

13. Comparing the Effectiveness of Acoustic Deterrents to Operational Curtailment in Reducing Bat Fatality ........................ 17

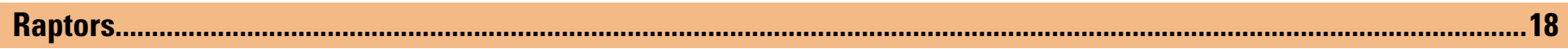

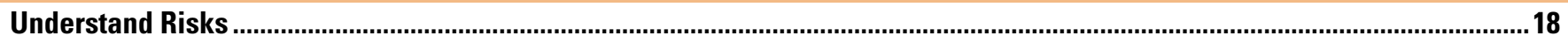

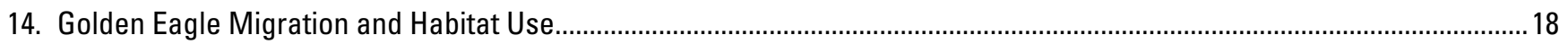

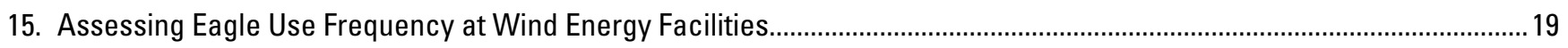

16. Golden Eagle Movement and Conservation in Coastal Southern California .......................................................................19

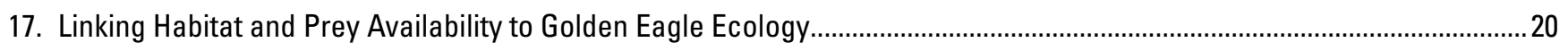

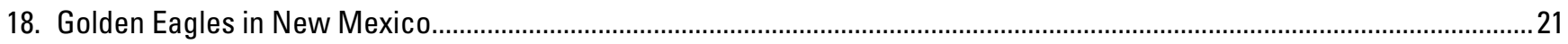

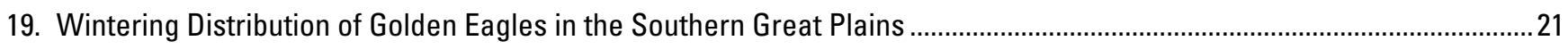

20. Tracking Bald Eagles Near Wind Energy Facilities in the Central Great Plains .....................................................................21

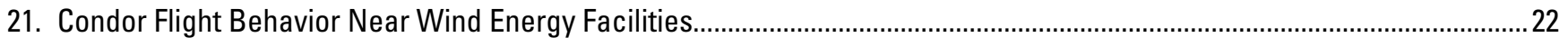

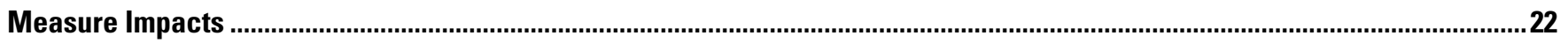

22. Population Demography of Golden Eagles Near the Altamont Pass Wind Resource Area, California ..................................22

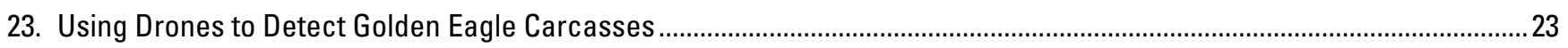

Inform Solutions

24. Golden Eagle Monitoring Plan for the Desert Renewable Energy Conservation Plan Area ...................................................2

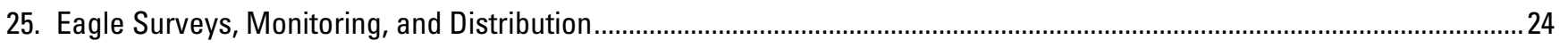

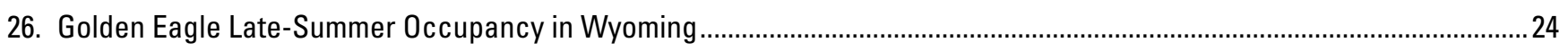

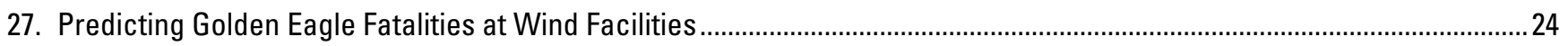

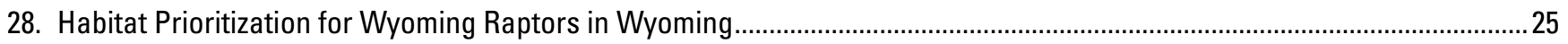

29. Potential Interactions of Migrating Raptors and Wind Energy Sites at the International Scale .......................................25

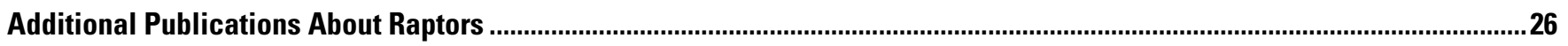


Great Lakes, Coastal, and Marine Birds

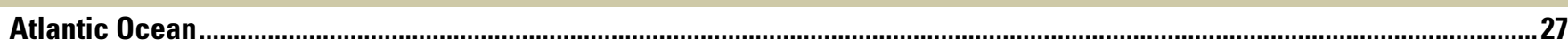

30. Potential Impacts of Offshore Wind Energy Projects on Endangered Roseate Terns ........................................................2

31. Evaluating Acoustic Sensitivity of Diving Birds to Offshore Energy Development Activities ..............................................28

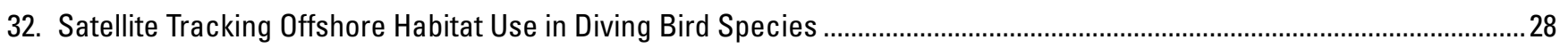

33. External GPS-GSM-Based Transmitters for Tracking Seabirds......................................................................................29

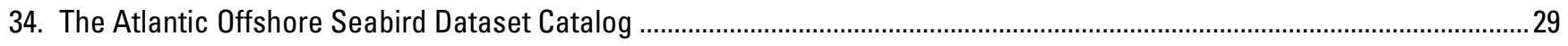

35. Modeling of Atlantic Coast Seabird Distributions ................................................................................................... 30

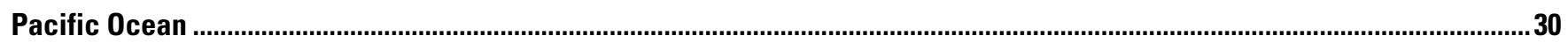

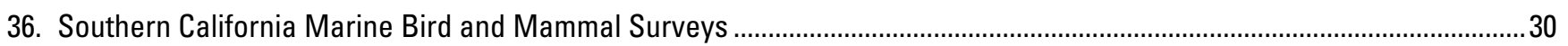

37. Predictive Modeling of Marine Bird Spatial Distributions on the Pacific Outer Continental Shelf ......................................31

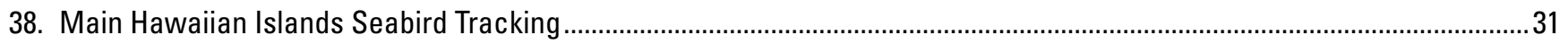

Gulf of Mexico

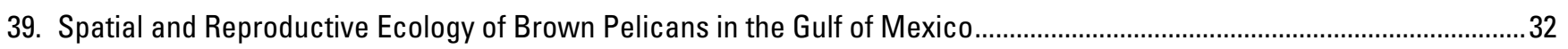

Great Lakes

40. Monitoring and Mapping Avian Resources in Nearshore and Open Waters of Lake Michigan.........................................32

41. Documenting Movements, Habitat Use, and Foraging Patterns of Common Loons and Long-Tailed Ducks.........................33

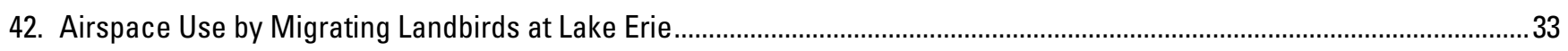

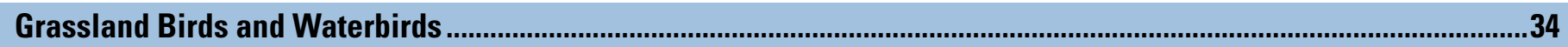

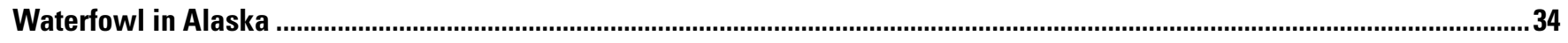

43. Habitat Use of Molting Geese in the National Petroleum Reserve-Alaska.................................................................34

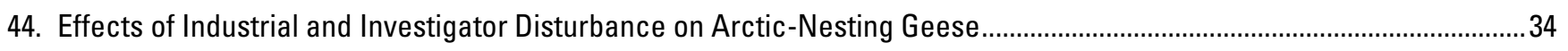

45. Quantifying Shifts in Waterfowl and Their Habitat in the National Petroleum Reserve-Alaska........................................35

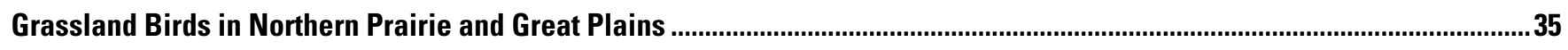

46. A Mitigation Tool for Estimating the Impact of Wind Energy Development on Grassland Birds

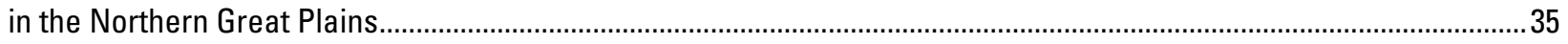

47. Birds and the Bakken Formation: Integration of Oil Well, Land Cover, and Species Distribution

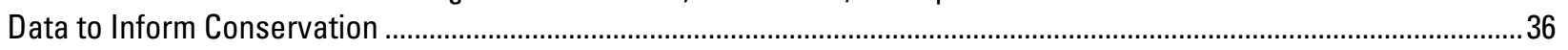

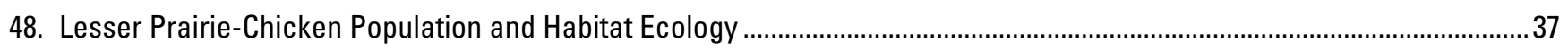

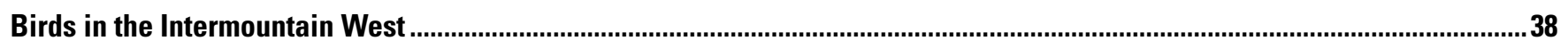

49. Impacts of Oil and Gas Development on Greater Sage-Grouse Lek Attendance ..............................................................38

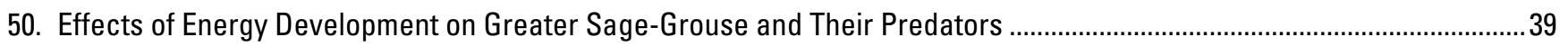

51. Implications of Anthropogenic Activities on Greater Sage-Grouse Populations in Nevada .................................................40

52. Breeding Sagebrush Songbird Responses to Gas Development: Patterns and Mechanisms ............................................ 40

Additional Publications About Songbirds, Grassland Birds, and Waterbirds ............................................................................41

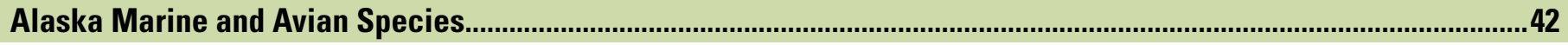

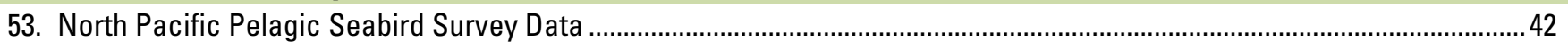

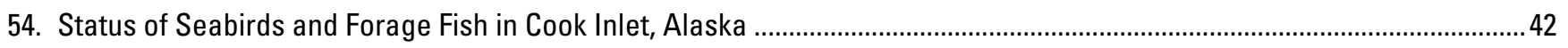

55. Gulf Watch Alaska Program for Quantifying Coastal Marine Ecosystem Change ........................................................ 42

56. Long-Term Response of Wildlife to the Exxon Valdez Oil Spill in Alaska............................................................................ 43

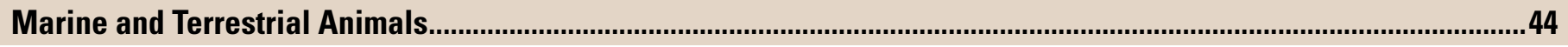

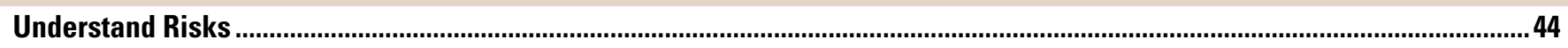

57. Influence of Energy Development on Mule Deer Migrations....................................................................................... 44

58. Florida Manatee Movement and Habitat Use in the Northern Gulf of Mexico ................................................................ 44

59. Gulf of Mexico Marine Assessment Program for Protected Species: Sea Turtles ............................................................. 45

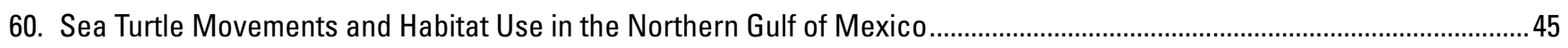

61. Canid Distribution and the Potential Impacts of Energy Development in Nebraska ............................................................4

62. Potential Effects of Wind Farms on Montane Carnivores in New England .......................................................................... 46 


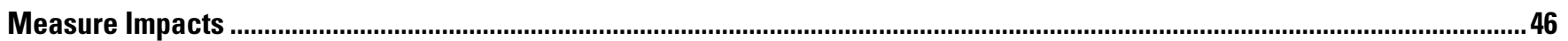

63. Quantifying Response of Pacific Walrus to Ocean Noise in the Arctic...................................................................................46

64. Measuring Impacts of Industrial Activities on Polar Bears ..................................................................................................4

65. Pygmy Rabbit Presence and Abundance in Relation to Gas Field Development ................................................................47

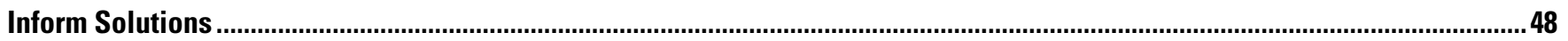

66. Distribution and Abundance of Pacific Walrus in Relation to Offshore Development in Alaska ...........................................48

67. Mitigating the Impacts of Energy Development on Polar Bears ...............................................................................................49

68. Effects of Changes in Coastal Florida Power Generation on Florida Manatees ....................................................................50

Desert Tortoise ............................................................................................................................................................

69. Effects of Solar Development and Habitat Alterations on Desert Tortoises .......................................................................51

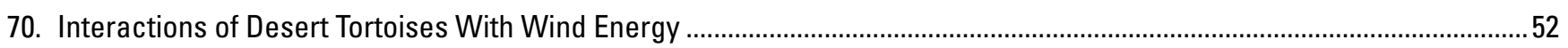

71. Desert Tortoise Disease Risks Associated with Translocations ........................................................................................53

72. Shelter Choices for Tortoises During Temperature Extremes ........................................................................................5

Additional Publications About the Desert Tortoise ...............................................................................................................54

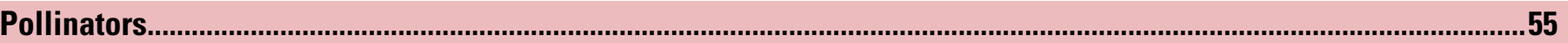

73. Impact of Biofuel Crop Production on Pollinators in the Northern Great Plains .................................................................55

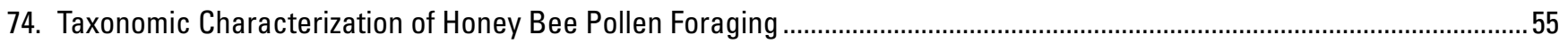

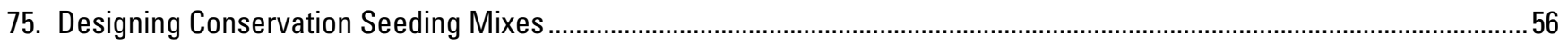

Fish and Other Aquatic Species ...............................................................................................................................57

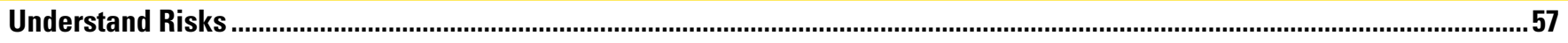

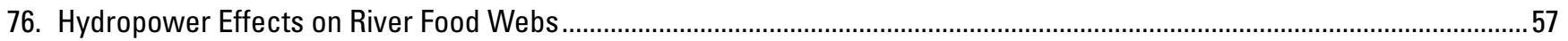

77. Vulnerability of Brook Trout Streams to Shale Gas Development in the Upper Susquehanna River Basin............................57

78. Legacy Brine Contamination From Oil Production Effects on Amphibian Survival ................................................................59

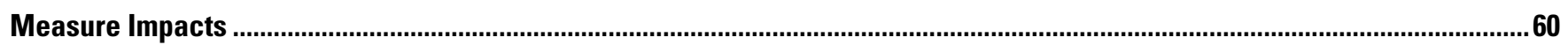

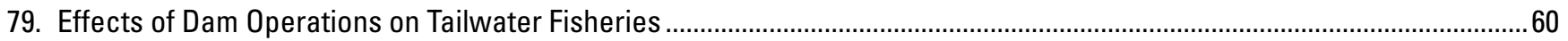

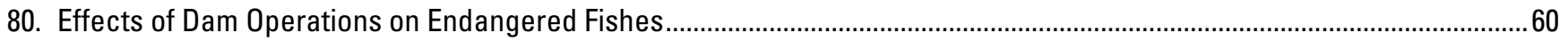

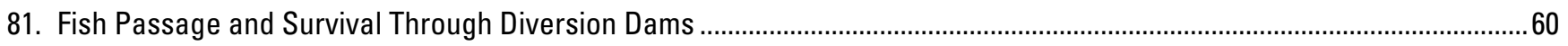

82. Toxicity Associated With Produced Waters From Oil and Gas Activity in the Bakken Region ..............................................61

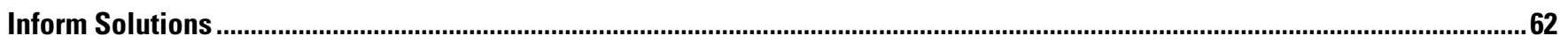

83. Behavioral Studies of Fish Routed Around a Hydroelectric Dam in the North Fork Reservoir ...............................................62

84. Feasibility of Reintroducing Anadromous Salmonids to Reservoirs Above High-Head Dams ................................................62

85. Informing Fish Passage Decisions at the Yale and Merwin Projects on the Lewis River .......................................................63

86. Structured Decision Making for the Management of Glen Canyon Dam.................................................................................63

87. Full-Scale Development and Evaluations of Fish Passage Structures and Fish Behavior.....................................................63

88. Biotelemetry Studies of Fish Behavior and Passage Through Dams .................................................................................64

89. Risks and Benefits of Actively Managing a Small Bull Trout Population .................................................................................65

90. Optimizing Hydropower Operations to Reduce Eel Mortality and Turbine Shutdown ...........................................................66

91. Using Genomics to Better Understand Habitat Use of the Atlantic Sturgeon.......................................................................66

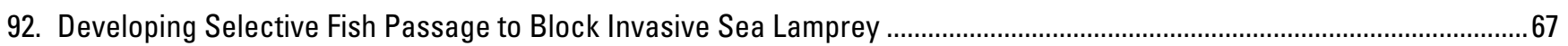

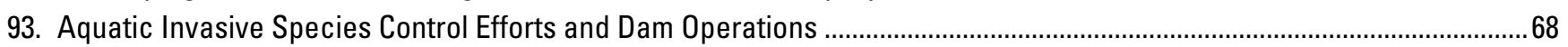

94. Natural Salmon Recolonization Following Condit Dam Removal ...............................................................................................6 68

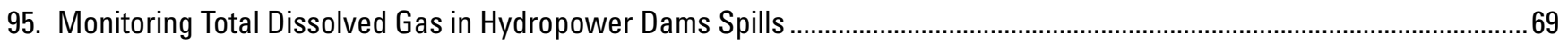

96. Maintenance of Instream Flows and Water Temperatures for Salmon Egg Incubation ..........................................................69

97. Improving Stream Temperature With Modification to Hydropower Dam Operation.................................................................70

98. Land Use and Microhabitat Effects on Salamanders in the Central Appalachian Coalfields .................................................70 
Wildlife Habitats and Ecosystem Functions . 71

99. Opportunities for Restoring Monarch Butterfly Habitat in the Midwestern United States .................................................. 71

100. Long-Term Recovery of Vegetation Along Utility Lines ...............................................................................................

101. Effects of Energy Development on Environmental Resources of the Williston Basin .......................................................72

102. Evaluating Bioenergy Opportunities in the Southwest............................................................................................ 73

103. Land-Cover Changes Associated With Recent Energy Development in the Williston Basin ...............................................73

104. Ecological Effects of Brine Contamination in the Prairie Pothole Region.............................................................................74

105. Shifts in Microbial Resistance Mechanisms in Surface Waters Impacted by Unconventional Oil and Gas (UOG) Wastewaters ...........................................................................................................

106. Biogeochemistry and Toxicology of a Stream Impacted by Unconventional Oil and Gas (UOG)

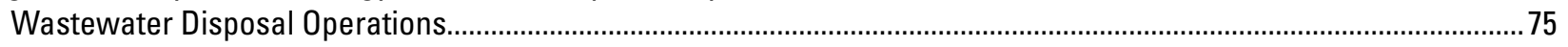

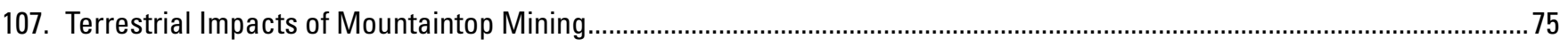

108. Bioenergy Production and Landscape Change in the Southeastern United States ...........................................................76

109. Predicting the Effects of Wave Energy Facilities on Nearshore Ecosystems ......................................................................76

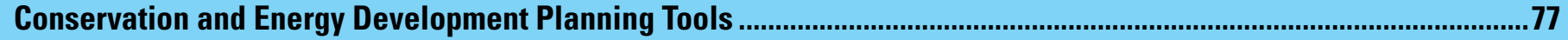

110. Sensitive and Rare Plant Distributions and Energy Development

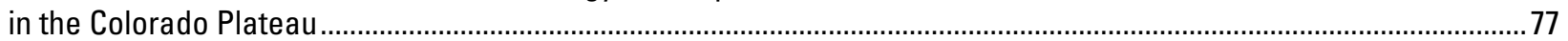

111. Ecological Restoration and Native Plant Development in Hot Desert Systems...................................................................78

112. Evaluating Reclamation Success Following Oil and Gas Development .............................................................................79

113. Informing Energy Development Siting Decisions With Vertebrate Biodiversity Measures.....................................................8 80

114. Modeling of Cumulative Impacts for Conservation Planning and Renewable Energy Development

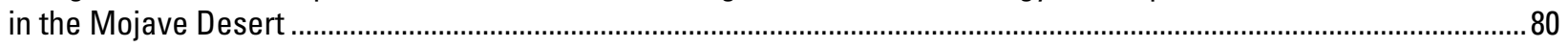

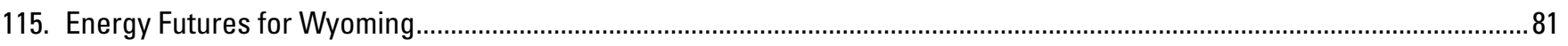

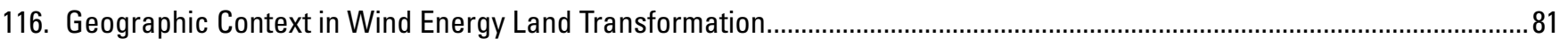

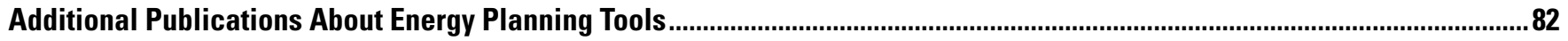

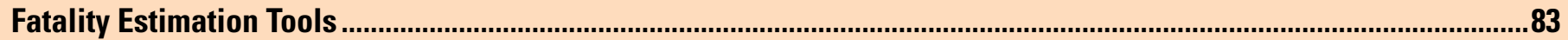

117. Advances in Estimating Fatalities From Collisions With Energy Infrastructure ...................................................................83

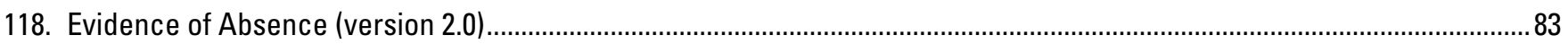

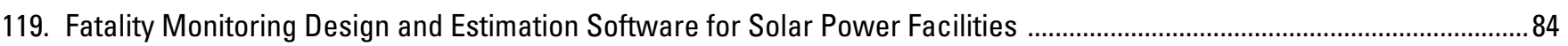

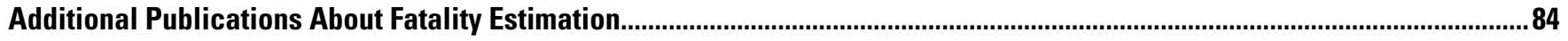

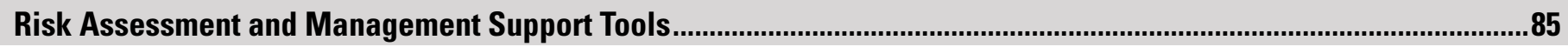

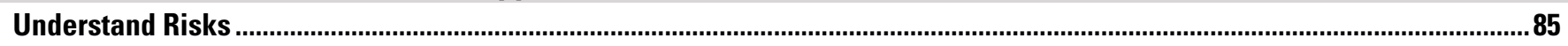

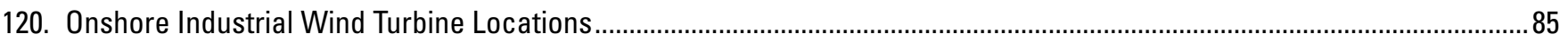

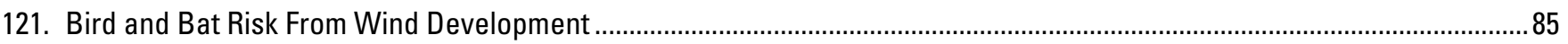

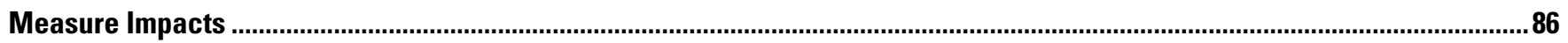

122. Advancing Wildlife Monitoring Technologies at Wind and Solar Facilities................................................................86

123. Tools to Assess Energy Development Impacts on Sensitive Birds and Bats ..................................................................8

124. Detecting Population-Level Impacts of Wind Energy Development.......................................................................... 87

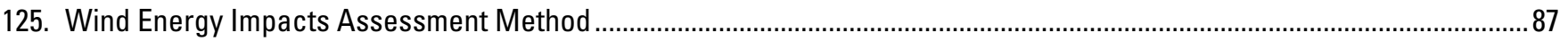




\section{Energy Icons}

Each project is associated with a type of energy production or transmission. Types of energy production or transmission are represented by the following icons:
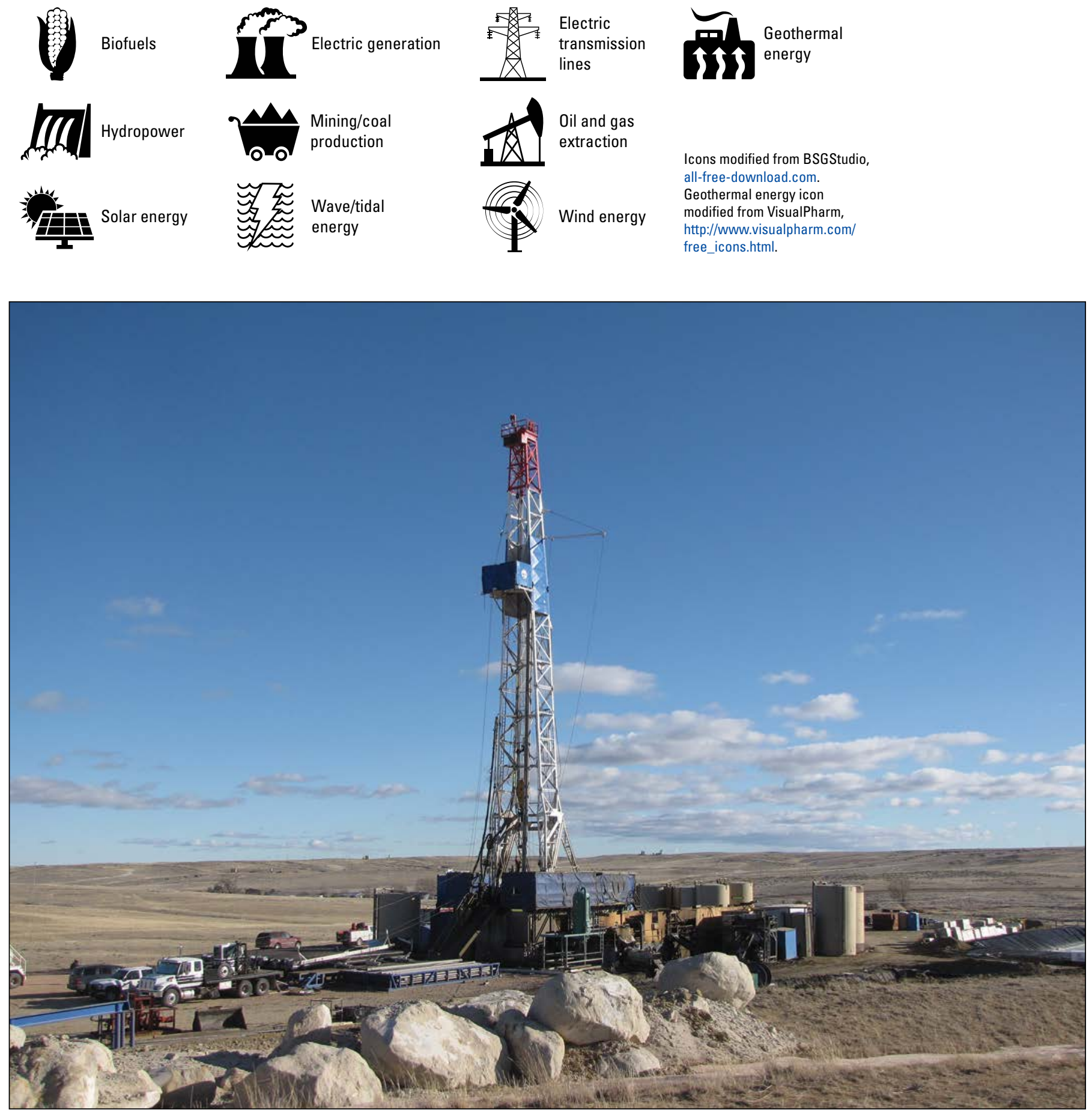
surface disturbance due to the rig's long reach. Photograph by Bureau of Land Management. 


\section{Study Locations}

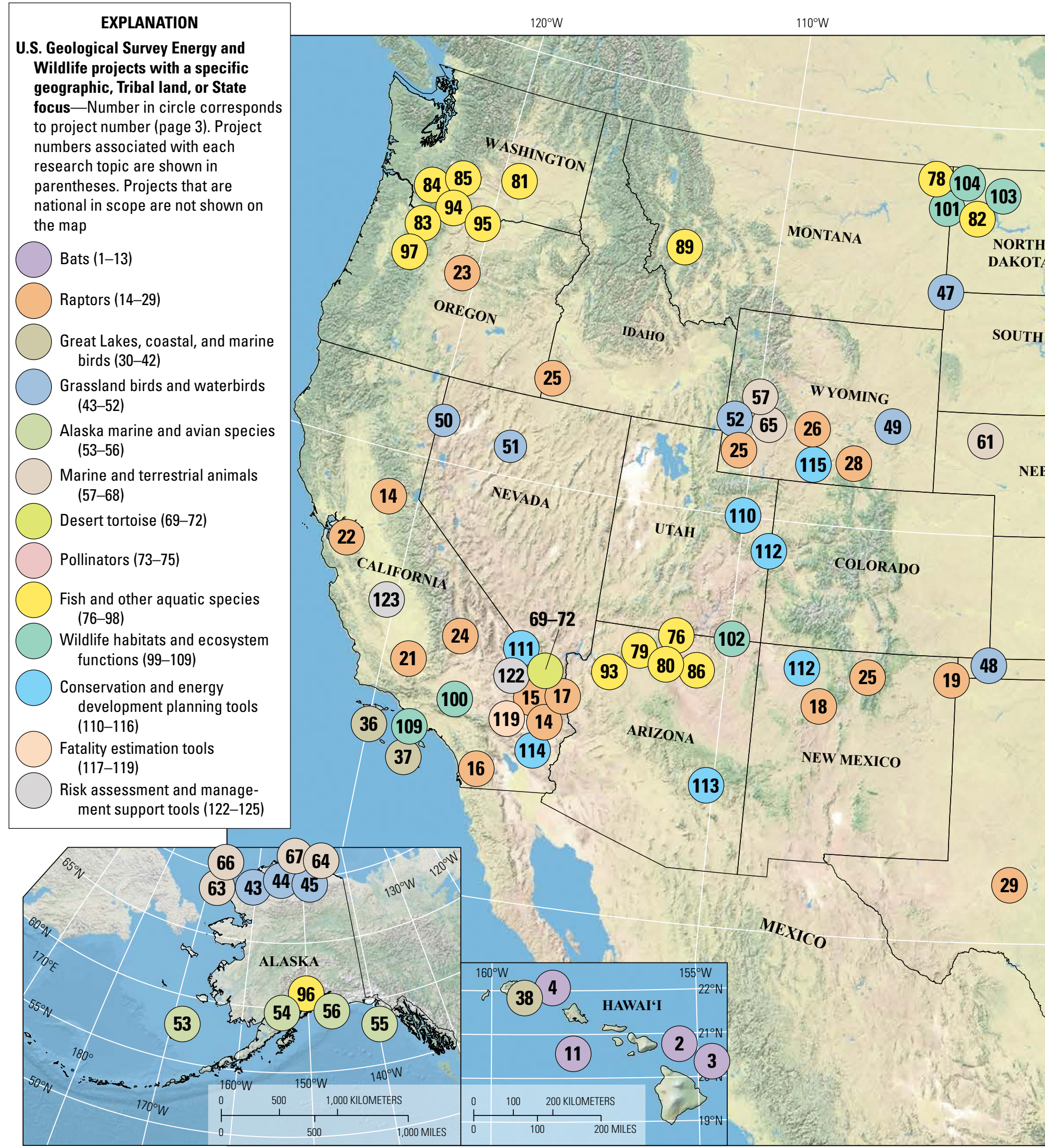

Map image is the intellectual property of Esri and is used herein under license. Copyright (C) 2014 Esri and its licensors. All rights reserved. Universal Transverse Mercator projection, zone 14 


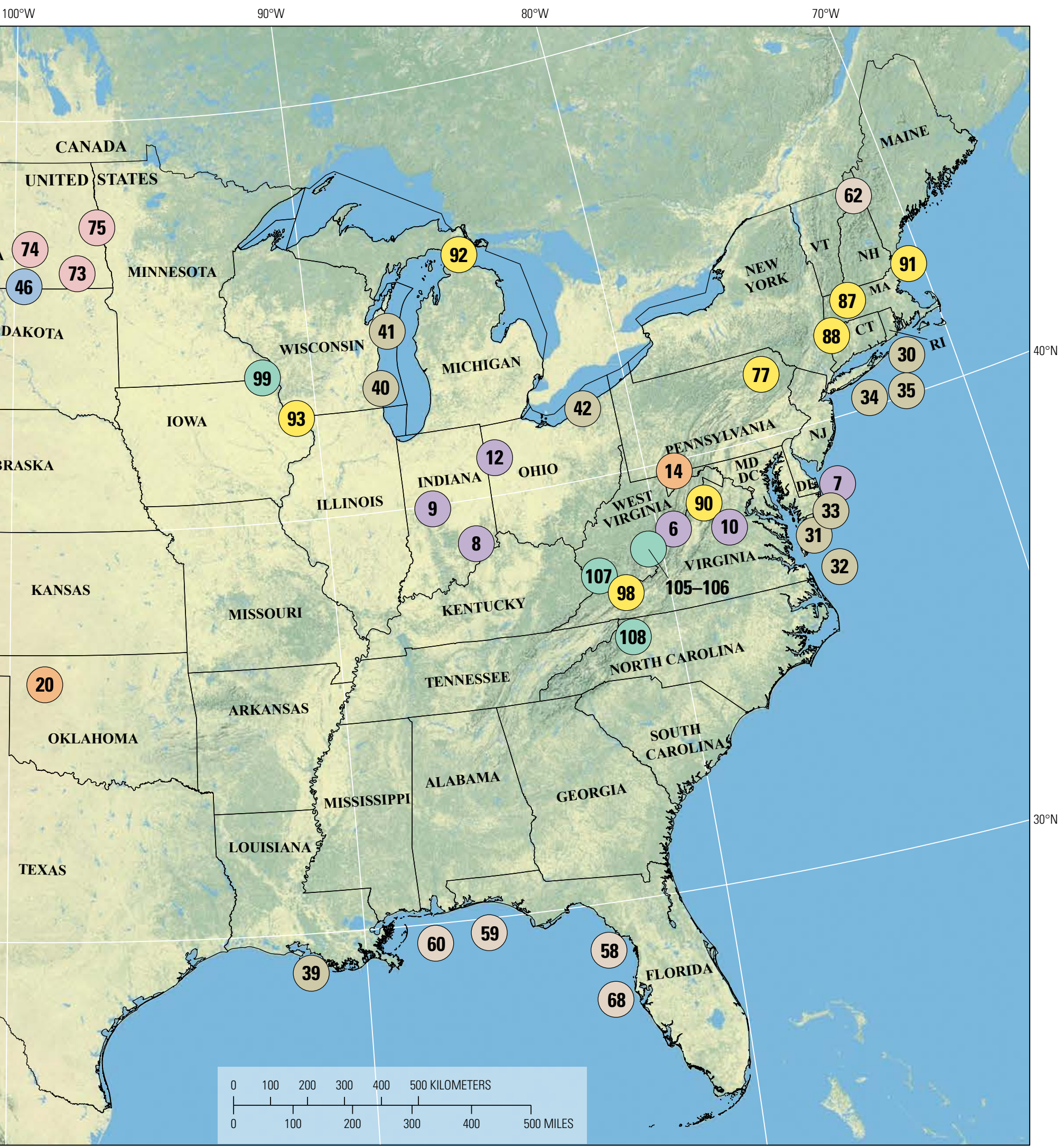




\section{Project Descriptions}

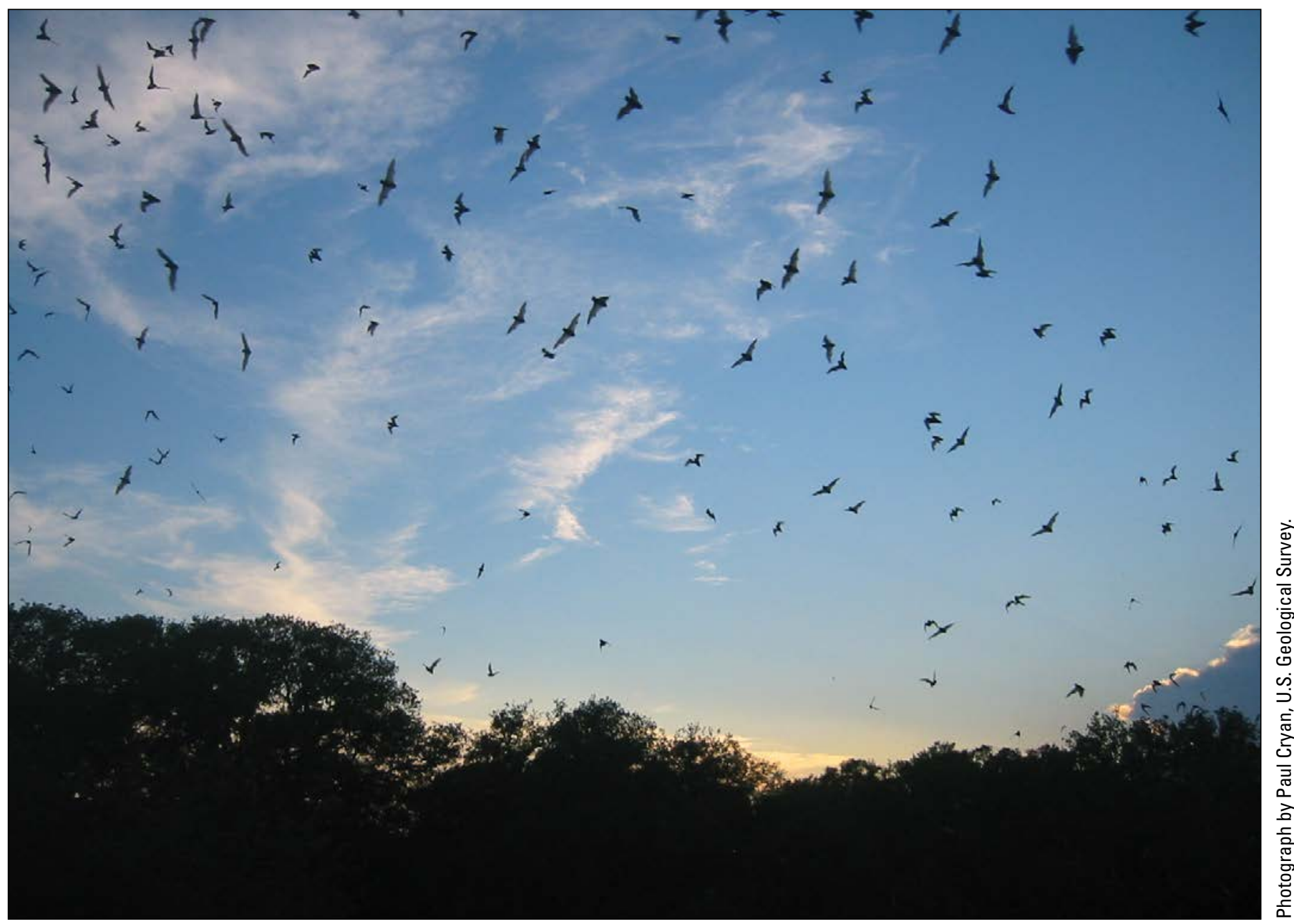

Bat colony flying at dusk.

\section{Bats}

\section{Understand Risks}

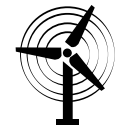

\section{Understanding and Reducing Bat} Fatalities Associated With Wind Turbines

Migratory bat species that roost in trees, or tree bats, are disproportionately affected by wind turbines, in part because they appear to be attracted to these structures. USGS science has led to new discoveries about these species, such as the consistent patterns in the way tree bats approach and dangerously interact with turbines at night (for example, making extremely close approaches on the downwind side of these structures), and identified areas of the continent where risk might be higher (such as the Great Plains, the Great Lakes region, and areas adjacent to coastal wintering areas). Working from this foundation, current USGS science aims to apply understanding of bat behaviors, seasonal distribution, and perception toward efficient and effective ways of reducing bat interactions with wind turbines.

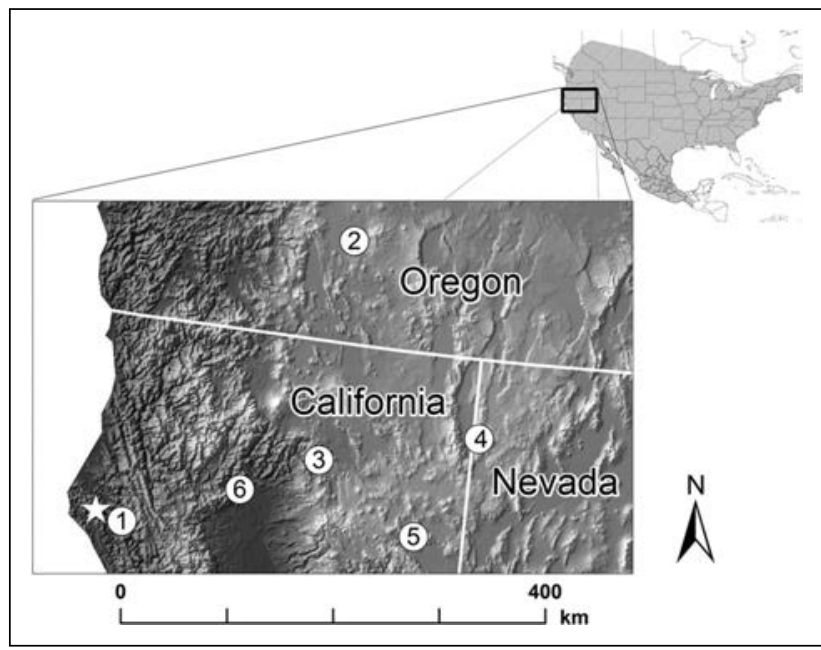

Locations of a free-ranging hoary bat recorded using a miniature Global Positioning System tag in October 2014 (from Weller and others, 2016). 


\section{Contact}

Paul Cryan, USGS Fort Collins Science Center, cryanp@usgs.gov, (970) 226-9389

\section{Publications}

O’Shea, T.J., Cryan, P.M., Hayman, D.T.S., Plowright, R.K., and Streicker, D.G., 2016, Multiple mortality events in batsA global review: Mammal Review, v. 46, no. 3, p. 175-190, https://doi.org/10.1111/mam.12064.

Weller, T.J., Castle, K.T., Liechti, Felix, Hein, C.D., Schirmacher, M.R., and Cryan, P.M., 2016, First direct evidence of longdistance seasonal movements and hibernation in a migratory bat: Scientific Reports, v. 6, no. 34585, https://doi.org/10.1038/ srep34585.

Castle, K.T., Weller, T.J., Cryan, P.M., Hein, C.D., and Schirmacher, M.R., 2015, Using sutures to attach miniature tracking tags to small bats for multimonth movement and behavioral studies: Ecology and Evolution, v. 5, no. 14, p. 2980-2989, https://doi.org/10.1002/ece3.1584.

Hayes, M.A., Cryan, P.M., and Wunder, M.B., 2015, Seasonally-dynamic presence-only species distribution models for a cryptic migratory bat impacted by wind energy development: PLOS ONE, v. 10, no. 7, e0132599, https://doi.org/10.1371/journal.pone.0132599.

Hayes, M.A., Ozenberger, Katharine, Cryan, P.M., and Wunder, M.B., 2015, Not to put too fine a point on it-Does increasing precision of geographic referencing improve species distribution models for a wide-ranging migratory bat?: Acta Chiropterologica, v. 17, no. 1, p. 159-169, https://doi.org/10.3161/15081109ACC2015.17.1.013.

Cryan, P.M., Gorresen, P.M., Hein, C.D., Schirmacher, M.R., Diehl, R.H., Huso, M.M., Hayman, D.T.S., Fricker, P.D., Bonaccorso, F.J., Johnson, D.H., Heist, Kevin, and Dalton, D.C., 2014, Behaviors of bats at wind turbines: Proceedings of the National Academy of Sciences of the United States of America, v. 111, no. 42, p. 15126-15131, https://doi.org/10.1073/ pnas. 1406672111.

Cryan, P.M., Stricker, C.A., and Wunder, M.B., 2014, Continental-scale, seasonal movements of a heterothermic migratory tree bat: Ecological Applications, v. 24, no. 4, p. 602-616, https://doi.org/10.1890/13-0752.1.

\section{Vocalization Behavior of Bats}

A common assumption of bat studies is that species capable of echolocation will consistently call during flight. Scientists with the USGS and the University of Hawai'i at Hilo are using synchronized thermal video imagery and acoustic recordings of the endangered Hawaiian hoary bat to observe bat flight and echolocation behavior. The study found that bats in flight may often forgo echolocation or do not always vocalize in a way that is detectable with common sampling methods. Silent flight behavior may be more prevalent in echolocating bats than previously appreciated and has profound implications for ecological research and population monitoring. Given the current trend toward reliance on acoustic detection as part of bat conservation and management actions, an increased understanding of vocalization behavior clearly is needed, particularly for vocalization rates of bats flying near wind turbines. Identifying silent behavior by bats may improve monitoring methods and focus management actions.

\section{Contact}

Marcos Gorresen, USGS Pacific Islands Ecosystems Research Center, mgorresen@usgs.gov, (808) 985-6407

\section{Publication}

Gorresen, P.M., Cryan, P.M., Montoya-Aiona, Kristina, and Bonaccorso, F.J., 2017, Do you hear what I see? Vocalization relative to visual detection rates of Hawaiian hoary bats (Lasiurus cinereus semotus): Ecology and Evolution, prepublication early view, https://doi.org/10.1002/ece3.3196.

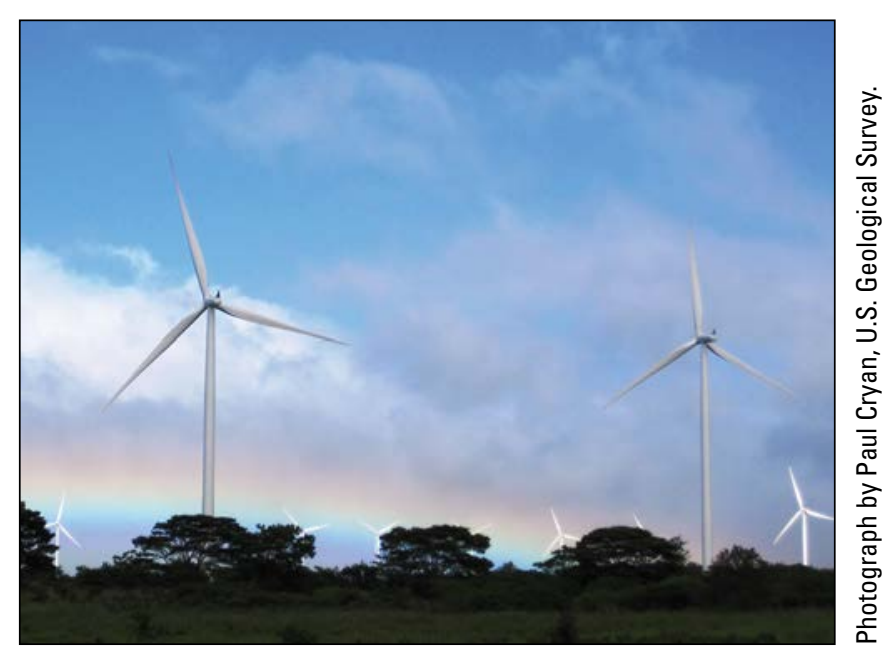

Bats that roost in trees, or tree bats, are more likely to interact with wind turbines, leading some scientists to speculate that they may be visually mistaking wind turbines as trees.

\footnotetext{
(
} 


\section{Modeling Foraging Habitat Suitability of the Hawaiian Hoary Bat}

Quantitative measures of habitat use by tree-roosting bat species have frequently faced the difficulty of detecting sparsely distributed and vocally cryptic individuals at locations where samples often yield low encounter rates. The current study by the USGS and the University of Hawai' $i$ at Hilo will concurrently apply thermal videography and echolocation sampling to more directly determine the occurrence and activity of the endangered Hawaiian hoary bat than previous approaches that have relied solely on acoustic detection or bat capture. Foraging habitat suitability will be related to bat occurrence, the frequency of feeding events, and insect abundance using multistate occupancy models, which can be more informative than simple models of presence and assumed absence. This approach may allow managers to evaluate the relative importance of different areas to foraging bats and track the effects of habitat restoration efforts over time.

\section{Contact}

Marcos Gorresen, USGS Pacific Islands Ecosystems Research Center, mgorresen@usgs.gov, (808) 985-6407

\section{Detecting and Understanding Bat Fatalities}

A USGS study conducted on north O`ahu, Hawai'i, simultaneously monitored bats at turbines with thermal and nearinfrared cameras and nacelle-mounted acoustic detectors. Bats were more likely to be found near turbines when barometric pressure was low but rising, as well as during periods of low wind and warmer temperatures. Nightly insect and bat detections were significantly and positively correlated. This correlation between bat and insect presence may be a relatively simple predictor of bat activity and could help refine operational mitigation strategies.

\section{Contact}

Marcos Gorresen, USGS Pacific Islands Ecosystems Research Center, mgorresen@usgs.gov, (808) 985-6407

\section{Publication}

Gorresen, P.M., Cryan, Paul, Huso, Manuela, Hein, Cris, Schirmacher, Michael, Johnson, Jessica, Montoya-Aiona, Kristina, Brinck, Kevin, and Bonaccorso, Frank, 2015, Behavior of the Hawaiian hoary bat (Lasiurus cinereus semotus) at wind turbines and its distribution across the North Ko'olau mountains, O`ahu: Hilo, Hawai'i, University of Hawai'i at Hilo, Technical Report HCSU-064, 68 p., http://hdl.handle.net/10790/2585.

\section{The North American Bat Monitoring Program (NABat)}

North American bats are experiencing unparalleled population declines and face unprecedented risks from continuing and emerging threats including wind energy development. To better understand the ecological consequences of these declines, the USGS is leading the development and implementation of a multiorganizational North American Bat Monitoring Program (NABat). NABat is focused on the 46 species of bats common to Canada, the United States, and Mexico. NABat aims to help resource managers detect early signs

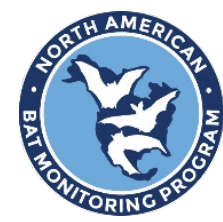
of population declines, better estimate extinction risk, establish conservation priorities, and evaluate the effectiveness of conservation actions. Currently, data management for the NABat program is provided by the USGS. A NABat advisory committee is composed of representatives from the U.S. Forest Service, USFWS, USGS, National Park Service (NPS), Canadian Wildlife Service, Canadian Wildlife Health Cooperative, Bat Conservation International, (BCI), and Wildlife Conservation Society Canada. Since implementation in 2015, NABat monitoring is now occurring in more than 39 States and 10 Canadian provinces.

\section{Contacts:}

Brian Reichert, USGS Fort Collins Science Center, breichert@usgs.gov, (970) 226-9245

Patricia Stevens, USGS Fort Collins Science Center, stevensp@usgs.gov, (970) 226-9499 


\section{Pre- and Post-Hibernation and Migratory Activity of Bats in the Central Appalachians}

The USGS and Virginia Polytechnic Institute and State University are using fixed-site, long-term acoustical monitoring near cave systems and along mountain ridgelines and adjacent side slopes in Virginia and West Virginia to determine the timing of hibernation entry and exit and associated swarm-area habitat use for the endangered Indiana bat and threatened northern long-eared bat. Additionally, this project is being conducted to examine the timing and location of migratory pulses for eastern red bats. These data can be used to inform siting criteria for proposed wind energy facilities to lessen the potential impacts on migratory bats that use Appalachian ridges as their primary migration corridors as well as to understand the potential risks for myotid bats making shortdistance movements to swarm habitats in the fall and post-hibernation and maternity habitats in the spring.

\section{Contact}

Mark Ford, USGS Virginia Cooperative Fish and Wildlife Research Unit, wmford@vt.edu, (540) 231-5927

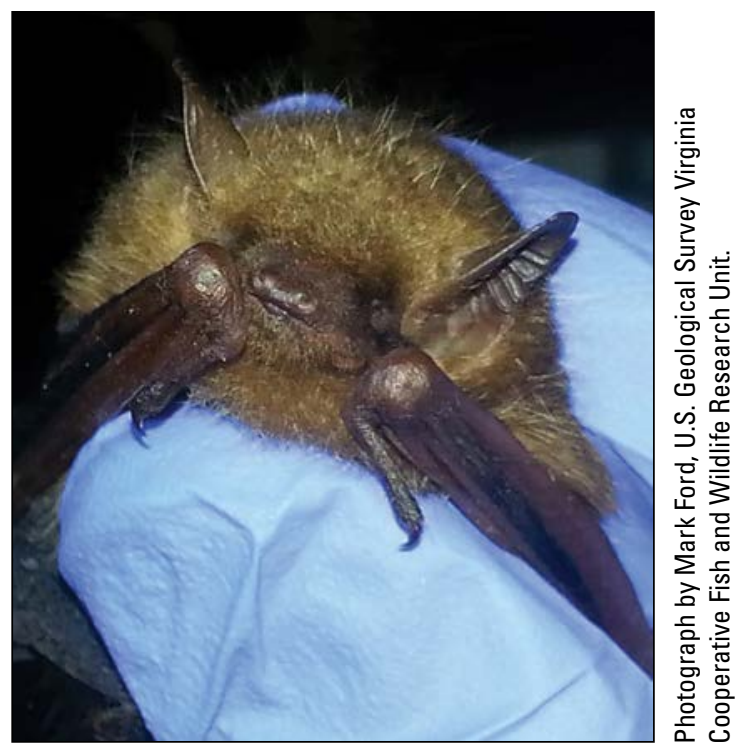

Northern long-eared bat, Rock Creek Park, Maryland.

\section{Mid-Atlantic Coastal Bat and Acoustic Nano-Tag Study}

The Virginia Department of Game and Inland Fisheries, USGS, and Virginia Polytechnic Institute and State University are studying migration timing and habitat use of eastern red bats in coastal areas of Virginia. With the move to develop coastal wind energy resources, there is a need to understand the potential for migration disruption and possible additive mortality of red bats and other migratory species. By understanding the timing of migration and offshore movements of these bats, it may be possible to design and implement wind energy mitigation measures, such as seasonal curtailment and (or) siting, to minimize interactions with bats. Red bats are being captured along the coast in Virginia, Maryland, and New Jersey prior to fall migration and in Virginia prior to spring migration and outfitted with very high-frequency nano-tags. Fixed sensor towers capable of tracking multiple bats simultaneously are being placed along the Virginia outer coast and in the Chesapeake Bay.

\section{Contact}

Mark Ford, USGS Virginia Cooperative Fish and Wildlife Research Unit, wmford@vt.edu, (540) 231-5927

\section{Measure Impacts}

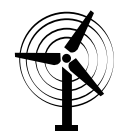

\section{Wind Energy Effects on the Indiana Bat}

The USGS developed a quantitative framework for understanding the effects of wind energy development on migratory bats by developing migratory connectivity models for the endangered Indiana bat. Using USFWS data to determine model parameters, this framework provides insight into the effects of wind energy on migratory patterns and spatial dynamics of bats and also examines the synergistic effects of white-nose syndrome (WNS) on bat mortality. Wind energy development and WNS affect bat populations differently. Wind energy development disproportionately affects small overwintering populations, whereas WNS will more likely extirpate large overwintering populations. These findings illustrate the importance of considering changes among groups of populations when managing the Indiana bat.

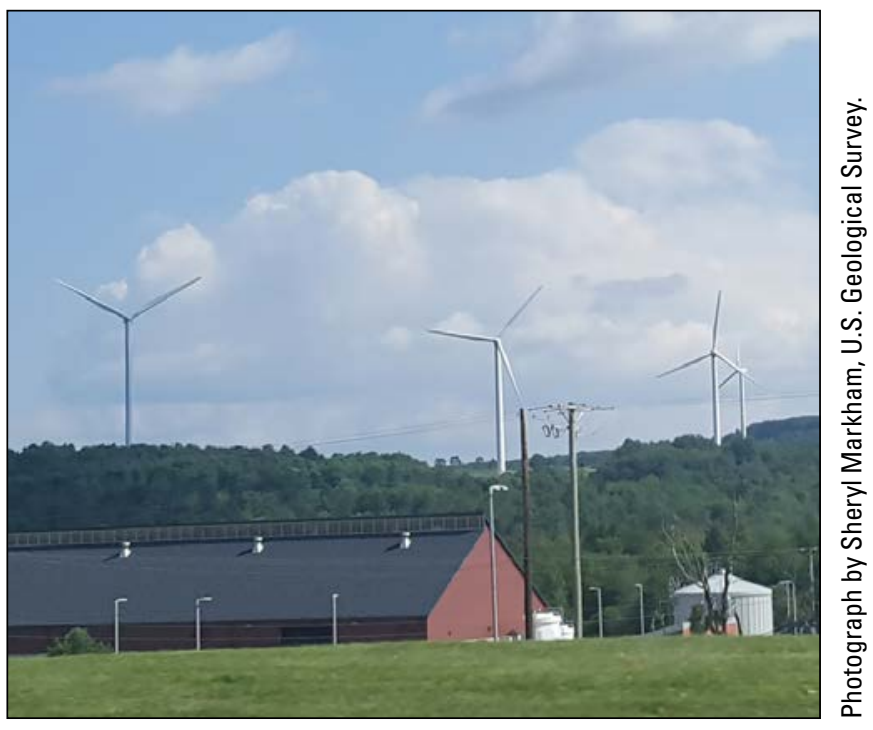

Wind turbines in York Township, Elkhart County, Indiana. 


\section{Contact}

Wayne Thogmartin, USGS Upper Midwest Environmental Sciences Center, wthogmartin@usgs.gov, (608) 781-6309

Publication

Erickson, R.A., Thogmartin, W.E., Diffendorfer, J.E., Russell, R.E., and Szymanski, J.A., 2016, Effects of wind energy generation and white-nose syndrome on the viability of the Indiana bat: PeerJ, v. 4, e2830, https://doi.org/10.7717/peerj.2830.

\section{Using Genetic Tools to Examine the Biology of Summer-Roosting Indiana Bats}

Indiana bats are at risk from wind turbines, and wide-ranging populations of Indiana bats have declined by approximately half since 1967, when the species was listed as endangered under the Endangered Species Act (ESA). Traditional tracking techniques have not enabled scientists to regularly monitor individual bats throughout a field season. Recent advances in genetic techniques have made it possible to uniquely identify animals using deoxyribonucleic acid (DNA) in mark-recapture studies. Preliminary work by the USGS has shown that DNA can be extracted from Indiana bat fecal pellets collected beneath roost trees. It is now possible to explore the relatedness of Indiana bat-colony members using genetic information and to estimate population sizes

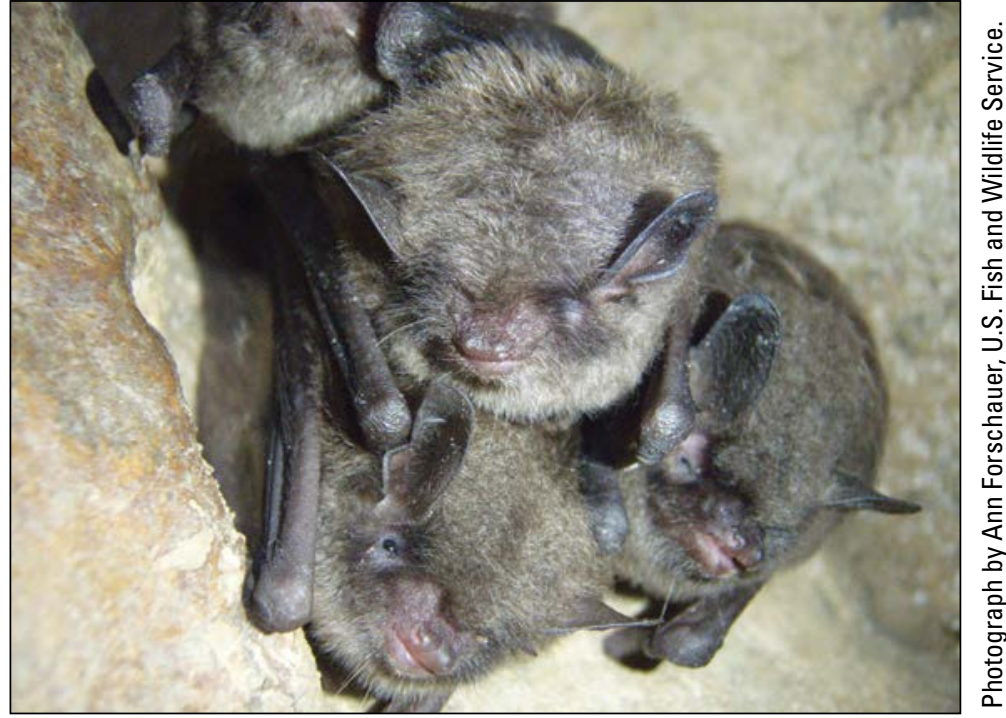

Indiana bats. using DNA. Accurate demographic and relatedness information can assist conservation managers in the management and recovery of the Indiana bat.

\section{Contact}

Sara Oyler-McCance, USGS Fort Collins Science Center, sara_oyler-mccance@usgs.gov, (970) 226-9197

\section{Publication}

Oyler-McCance, S.J., Fike, J.A., Lukacs, P.M., Sparks, D.W., O’Shea, T.J., and Whitaker, J.O., Jr., in press, Using non-invasive fecal DNA to investigate demographics of the endangered Indiana bat at summer roosts: Journal of Fish and Wildlife Management.

\section{Post-White-Nose Syndrome Assessment of Bat Distribution in the Mid-Atlantic and Northeast}

The USGS and Virginia Polytechnic Institute and State University, in cooperation with the USFWS, the National White-Nose Syndrome (WNS) Program, NPS, the U.S. Army, the U.S. Marine Corps, Virginia Department of Game and Inland Fisheries, and the National Council for Air and Stream Improvement are using multiyear acoustic data from more than 1,200 locations from the Appalachian Mountains to the Atlantic Coast, and from Virginia to New England, to determine post-WNS distribution and the community structure of bats. These data are being used to model current and future potential occupancy from individual forest to landscape level. Results can be used to inform managers and regulators of the likelihood that a rare, threatened, or endangered bat species will be found in or near wind energy development, surface mining, or oil and gas development activities on public lands. This project can also provide information on the level of effort required for acoustic monitoring of the endangered Indiana bat and threatened northern long-eared bat.

\section{Contact}

Mark Ford, USGS Virginia Cooperative Fish and Wildlife Research Unit, wmford@vt.edu, (540) 231-5927 


\section{Publications}

St. Germain, M.J., Kniowski, A.B., Silvis, Alexander, and Ford, W.M., 2017, Who knew? First Myotis sodalis (Indiana bat) maternity colony in the coastal plain of Virginia: Northeastern Naturalist, v. 24, no. 1, p. N5-N10, https://doi.org/10.1656/045.024.0110.

Ford, W.M., Silvis, Alexander, Rodrigue, J.L., Kniowski, A.B., and Johnson, J.B., 2016, Deriving habitat models for northern long-eared bats from historical detection data-A case study using the Fernow Experimental Forest: Journal of Fish and Wildlife Management, v. 7, no. 1, p. 86-98, https://doi.org/10.3996/012015-jfwm-004.

Reynolds, R.J., Powers, K.E., Orndorff, Wil, Ford, W.M., and Hobson, C.S., 2016, Changes in rates of capture and demographics of Myotis septentrionalis (northern long-eared bat) in western Virginia before and after onset of white-nose syndrome: Northeastern Naturalist, v. 23, no. 2, p. 195-204, https://doi.org/10.1656/045.023.0201.

Silvis, Alexander, Perry, R.W., and Ford, W.M., 2016, Relationships of three species of bats impacted by white-nose syndrome to forest condition and management: U.S. Forest Service Southern Research Station, General Technical Report SRS-214, 48 p., https://www.srs.fs.usda.gov/pubs/gtr/gtr_srs214.pdf.

Powers, K.E., Reynolds, R.J., Orndorf, Wil, Ford, W.M., and Hobson, C.S., 2015, Post-white-nose syndrome trends in Virginia's cave bats, 2008-2013: Journal of Ecology and the Natural Environment, v. 7, no. 4, p. 56-64, https://doi.org/10.5897/ jene2015.0507.

\section{Inform Solutions}

\section{Ultraviolet Illumination as a Means of Reducing Bat Activity and Risk at Wind Turbines}

Insectivorous bats are known for their ability to find and pursue flying insect prey at close range by using echolocation, but they also rely heavily on vision. Using a cue that only bats would perceive, the USGS is developing technologies to prevent bats from approaching wind turbines that might be mistaken for trees. In 2014, USGS scientists experimentally tested the ability of wild insectivorous bats to detect dim ultraviolet (UV) light and whether dim UV light could reduce bat activity. The scientists first confirmed that several species of bats were capable of detecting dim UV light. They then showed that Hawaiian hoary bat activity could be reduced in areas frequented by bats by illuminating trees with dim UV light. An operational turbine was subsequently illuminated with dim UV light prototypes and there was no indication of problems with the operations of the turbine when using this technique. Further research may determine whether dim UV light can reduce bat activity and fatality at operational wind farms, with the potential benefit of allowing operators to run turbines at maximum efficiency.

\section{Contacts}

Paul Cryan, USGS Fort Collins Science Center, cryanp@usgs.gov, (970) 226-9389

Marcos Gorresen, USGS Pacific Islands Ecosystems Research Center, mgorresen@usgs.gov, (808) 985-6407
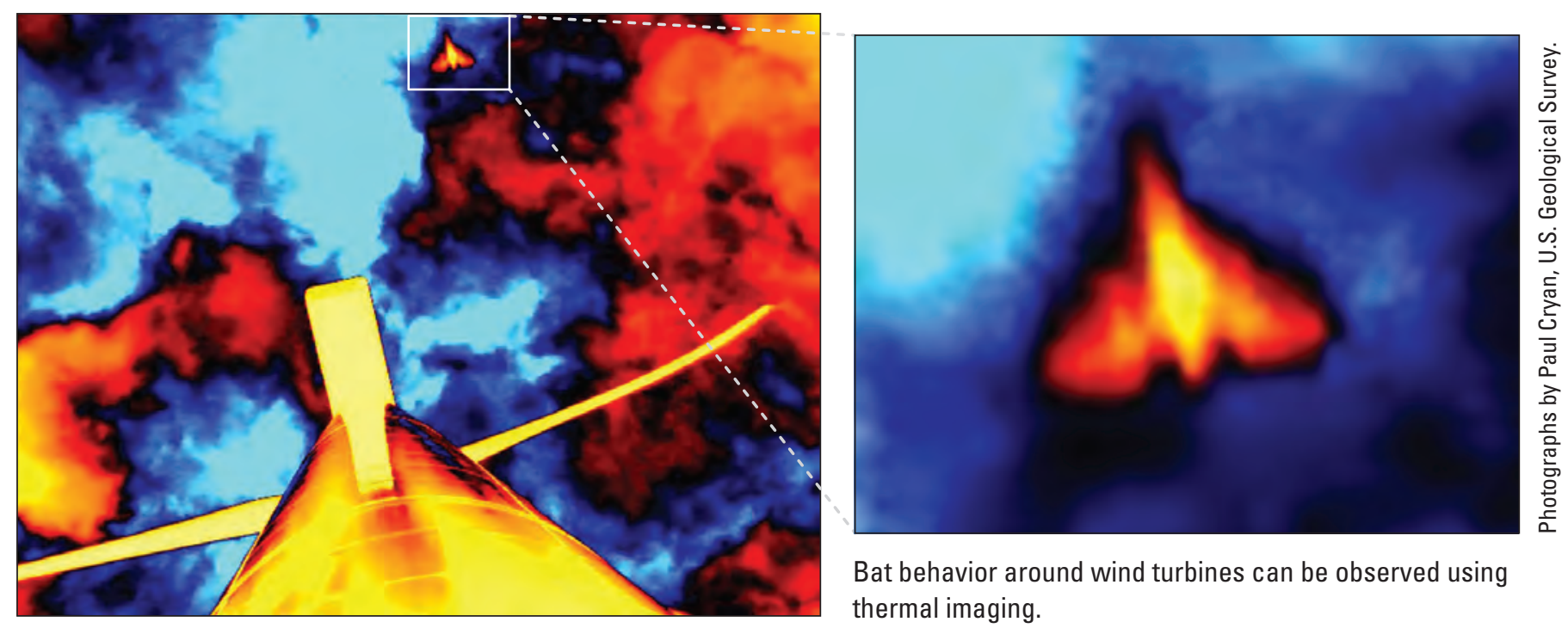

Bat behavior around wind turbines can be observed using thermal imaging. 


\section{Publications}

Cryan, P.M., Gorresen, P.M., and Dalton, D.C., 2015, Selectively perceptible wind turbine system: U.S. Patent Application Publication, pub. no. US 20160169501A1, https://patentimages.storage.googleapis.com/79/56/3f/61ba981e3ef538/ US20160169501A1.pdf.

Gorresen, P.M., Cryan, P.M., Dalton, D.C., Wolf, Sandy, and Bonaccorso, F.J., 2015, Ultraviolet vision may be widespread in bats: Acta Chiropterologica, v. 17, no. 1, p. 193-198, https://doi.org/10.3161/15081109acc2015.17.1.017.

Gorresen, P.M., Cryan, P.M., Dalton, D.C., Wolf, Sandy, Johnson, J.A., Todd, C.M., and Bonaccorso, F.J., 2015, Dim ultraviolet light as a means of deterring activity by the hoary bat Lasiurus cinereus semotus: Endangered Species Research, v. 28, no. 3, p. 249-257, https://doi.org/10.3354/esr00694.

\section{Wind Turbine Curtailment Strategies to Reduce Bat Fatality}

Wildlife fatalities due to collisions with wind turbines have sparked efforts to reduce the number of fatalities through operational management. Recent studies have shown that altering turbine operations when winds are below certain speeds can decrease the number of bat fatalities, but questions remain regarding optimal management. The USGS and colleagues are modeling the proportion of bat fatalities occurring under varying meteorological conditions at Avangrid Renewables' Blue Creek Wind Farm in Ohio to identify conditions that minimize both bat fatalities and energy production loss. The scientists are also investigating whether accurate and precise estimates of fatalities can be derived from carcass searches conducted at easily accessed areas, such as roads and pads beneath turbines.

\section{Contact}

Manuela Huso, USGS Forest and Rangeland Ecosystem Science Center, mhuso@usgs.gov, (541) 750-0948

\section{Comparing the Effectiveness of Acoustic Deterrents to Operational Curtailment in Reducing Bat Fatality}

Independent studies have shown that both operational curtailment and ultrasonic acoustic deterrents can be effective in reducing bat fatalities at wind energy facilities. A primary goal of this USGS and BCI study is to directly compare the costs and benefits of the acoustic deterrents to operational curtailment. Fatality rates, when both curtailment and acoustic deterrents are applied singly and in combination, are being compared with fatality rates at untreated turbines to determine if one of these methods is more effective, if they are equally effective, or if they might act synergistically when employed simultaneously.

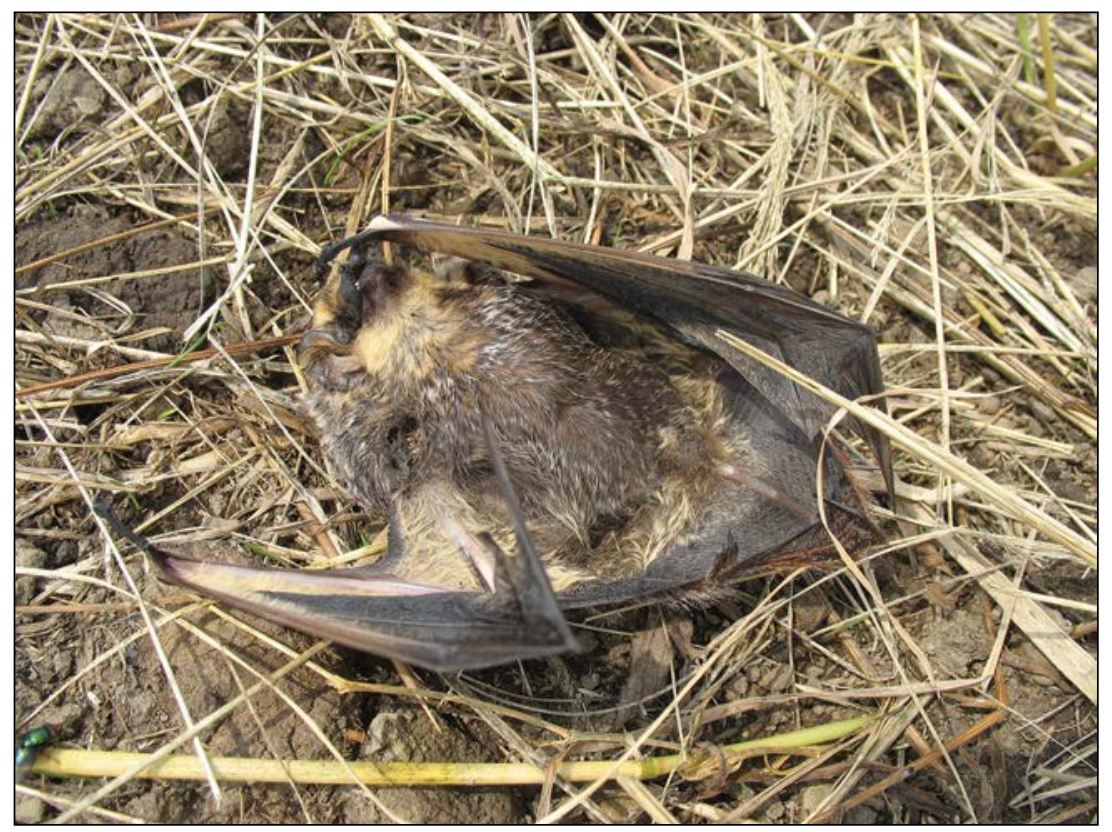

Contact

Manuela Huso, USGS Forest and Rangeland Ecosystem Science Center, mhuso@usgs.gov, (541) $750-0948$

Wind turbine bat fatality. 


\section{Raptors}

\section{Understand Risks}

\section{Golden Eagle Migration and Habitat Use}

The USGS is collecting information related to habitat use, home range, and population dynamics of golden eagles in the Central Appalachians, northeastern California, and the Mojave and Sonoran Deserts, using various methodologies including Global Positioning System-Global System for Mobile (GPS-GSM) communications telemetry, standard geographic information system (GIS) analyses, nest visits, and non-invasive genetic monitoring. The data collected have been used to model movement and to create risk models to assist resource management agencies in evaluating management options for this species. Results can inform resource managers about where and when eagles would be most at risk from disturbances associated with renewable energy structures. Data are being combined with datasets from other similar projects to create a framework and baseline to build an effective long-term golden eagle monitoring program in support of adaptive management.

\section{Contact}

Todd Katzner, USGS Forest and Rangeland Ecosystem Science Center, tkatzner@usgs.gov, (208) 426-5232

\section{Publications}

Brown, J.L., Bedrosian, Bryan, Bell, D.A., Braham, M.A., Cooper, Jeff, Crandall, R.H., DiDonato, Joe, Domenech, Robert, Duerr, A.E., Katzner, T.E., Lanzone, M.J., LaPlante, D.W., McIntyre, C.L., Miller, T.A., Murphy, R.K., Shreading, Adam, Slater, S.J., Smith, J.P., Smith, B.W., Watson, J.W., and Woodbridge, Brian, 2017, Patterns of spatial distribution of golden eagles across North America-How do they fit into existing landscape-scale mapping systems? Journal of Raptor Research, v. 51, no. 3, p. 197-215, https://doi.org/10.3356/JRR-16-72.1.

Rus, A.I., Duerr, A.E., Miller, T.A., Belthoff, J.R., and Katzner, T.E., 2017, Counterintuitive roles of experience and weather on migratory performance: The Auk, v. 134, no. 3, p. 485-497, https://doi.org/10.1642/AUK-16-147.1.

Sur, Maitreyi, Suffredini, Tony, Wessells, S.M., Bloom, P.H., Lanzone, Michael, Blackshire, Sheldon, Sridhar, Srisarguru, and Katzner, Todd, 2017, Improved supervised classification of accelerometry data to distinguish behaviors of soaring birds: PLOS ONE, v. 12, no. 4, e0174785, https://doi.org/10.1371/journal.pone.0174785.

Craig, E.H., Adams, J.R., Waits, L.P., Fuller, M.R., and Whittington, D.M., 2016, Nuclear and mitochondrial DNA analyses of golden eagles (Aquila chrysaetos canadensis) from three areas in western North America-Initial results and conservation

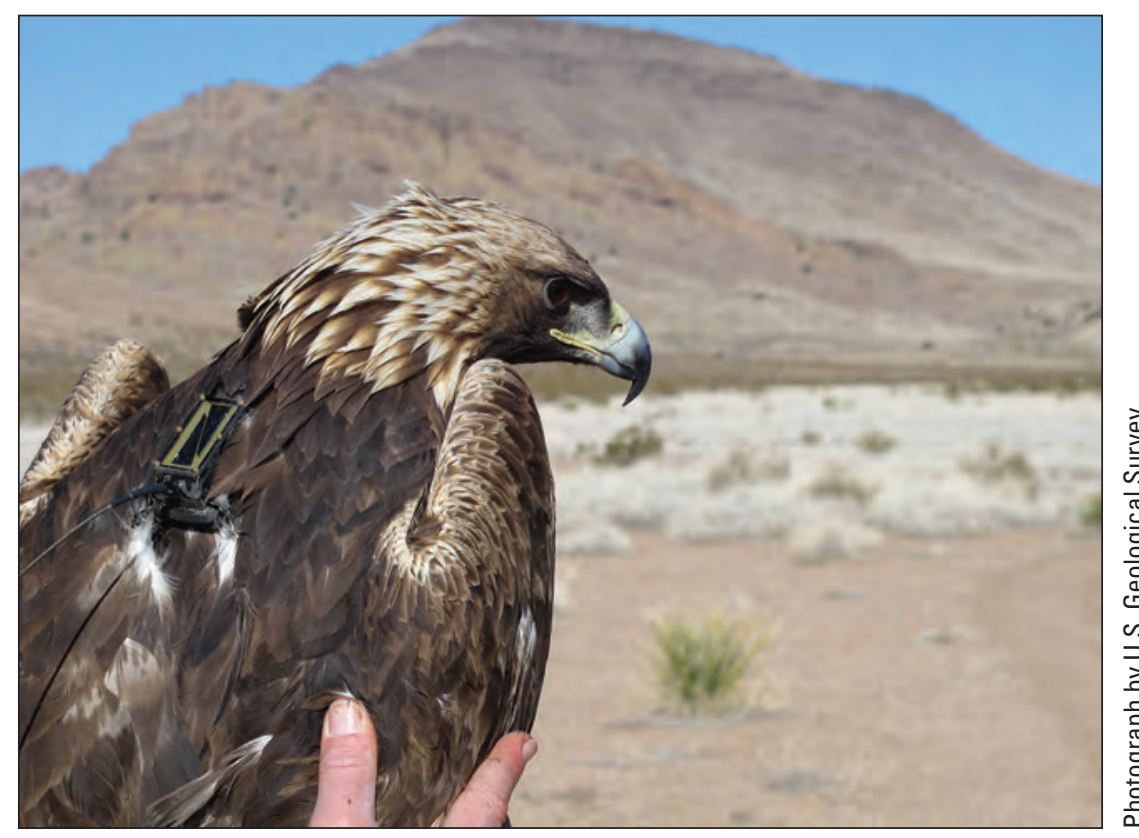
implications: PLOS ONE, v. 11, no. 10, e0164248, https://doi.org/10.1371/ journal.pone.0164248.

Doyle, J.M., Katzner, T.E., Roemer, G.W., Cain, J.W., Millsap, B.A., McIntyre, C.L., Sonsthagen, S.A., Fernandez, N.B., Wheeler, Maria, Bulut, Zafer, Bloom, P.H., and DeWoody, J.A., 2016, Genetic structure and viability selection in the golden eagle (Aquila chrysaetos), a vagile raptor with a Holarctic distribution: Conservation Genetics, v. 17 , no. 6 , p. 1307-1322, https://doi.org/10.1007/s10592-0160863-0.

Golden eagle with a GPS backpack. 


\section{Assessing Eagle Use Frequency at Wind Energy Facilities}

Operation of wind energy facilities can adversely affect eagles, among other wildlife. USFWS guidelines suggest wind facility operators or developers survey eagle use and calculate the risk to eagles across the project area; however, questions have arisen concerning the degree to which data from survey plots represent eagle use over an entire project area. The USGS is using existing telemetry data on golden eagles in the Mojave Desert, California, to help the USFWS compare eagle use within a plot to eagle use over an entire project area. Results can add to understanding of golden eagle activity and provide a context for interpreting survey data collected at potential wind energy facilities.

\section{Contact}

Todd Katzner, USGS Forest and Rangeland Ecosystem Science Center, tkatzner@usgs.gov, (208) 426-5232

\section{Publication}

Poessel, S.A., Bloom, P.H., Braham, M.A., and Katzner, T.E., 2016, Age- and season-specific variation in local and longdistance movement behavior of golden eagles: European Journal of Wildlife Research, v. 62, no. 4, p. 377-393, https://doi.org/10.1007/s10344-016-1010-4.

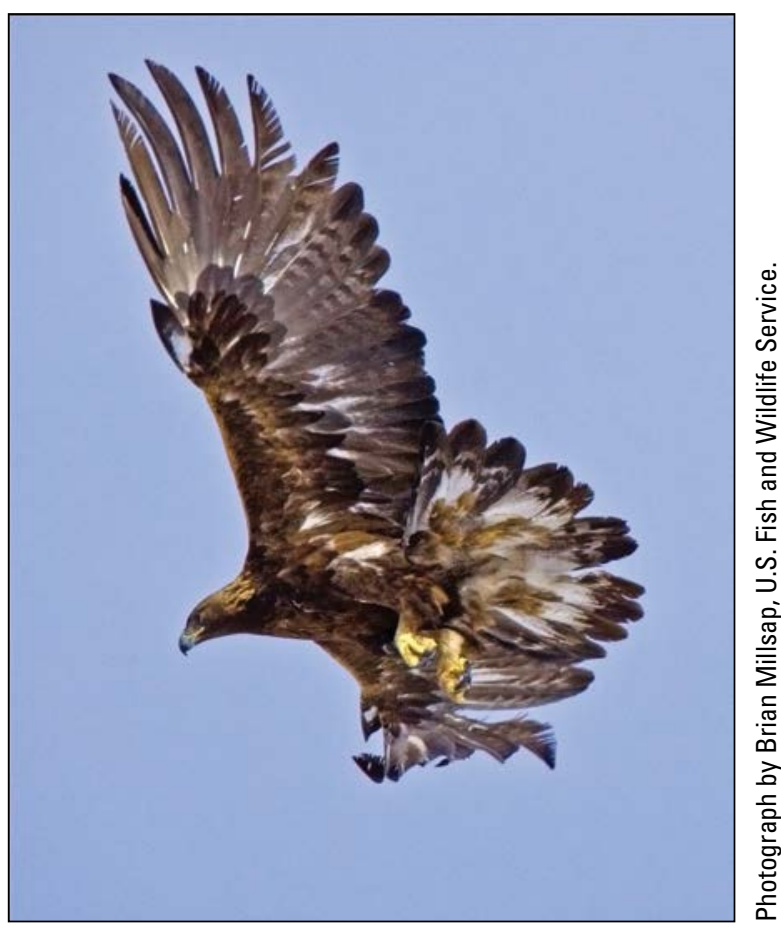

Golden eagle in flight.

\section{Golden Eagle Movement and Conservation in Coastal Southern California}

To evaluate the effects of human activities on golden eagles in coastal southern California, the USGS along with local agencies, State, and other Federal agencies began a multiyear golden eagle survey and tracking program in 2014. Thirty-seven golden eagles were captured in San Diego County, Orange County, and western Riverside County, California, and fitted with GPS backpack transmitters that send data over cellular networks, allowing scientists to track their movements. Movements ranged as far north as northern Nevada and southern Wyoming and as far south as the southern tip of Baja California, Mexico. By standardizing sampling designs and monitoring protocols with other ongoing studies of golden eagles in California, this work is expected to contribute to a broader understanding of the population status, demography, resource use, and genetic structure of golden eagles across a wide gradient of environmental conditions.

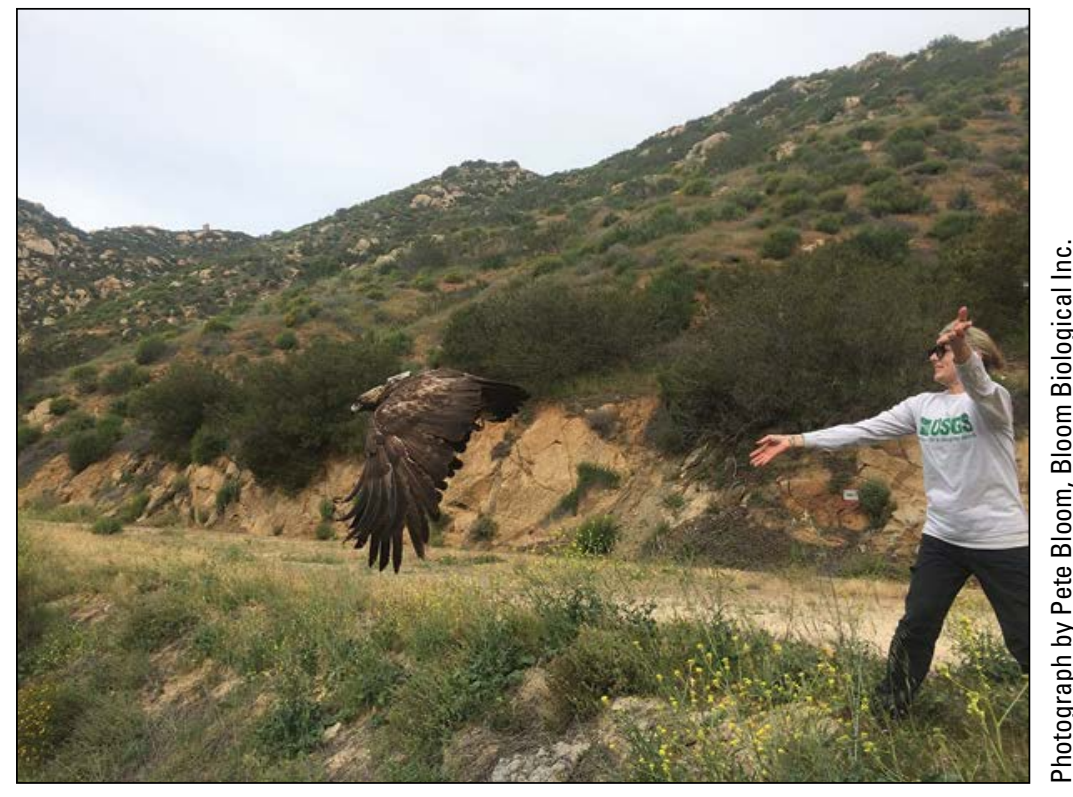

A U.S. Geological Survey scientist releases a golden eagle with a solarpowered GPS transmitter, San Diego County, California.

\section{Contacts}

Robert Fisher, USGS Western Ecological Research Center, rfisher@usgs.gov, (619) 225-6422

Melanie Madden, USGS Western Ecological Research Center, mmadden@usgs.gov, (619) 225-6450

Jeff Tracey, USGS Western Ecological Research Center, jtracey@usgs.gov, (619) 225-6457 


\section{Publications}

Tracey, J.A., Madden, M.C., Sebes, J.B., Bloom, P.H., Katzner, T.E., and Fisher, R.N., 2017, Biotelemetry data for golden eagles (Aquila chrysaetos) captured in coastal southern California, February 2016-February 2017: U.S. Geological Survey Data Series 1051, 35 p., https://doi.org/10.3133/ds1051.

Tracey, J.A., Madden, M.C., Sebes, J.B., Bloom, P.H., Katzner, T.E., and Fisher, R.N., 2016, Biotelemetry data for golden eagles (Aquila chrysaetos) captured in coastal southern California, November 2014-February 2016: U.S. Geological Survey Data Series 994, 32 p., https://doi.org/10.3133/ds994.

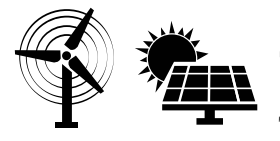

\section{Linking Habitat and Prey Availability to Golden Eagle Ecology}

The USGS is helping managers in California and Nevada design conservation strategies for eagles by constructing predictive models that link prey availability and abundance with eagle productivity and survival across the Desert Southwest. In addition, because eagle demographics are linked to the abundance of rabbit populations, scientists conducted a review and synthesis of population status, demographic patterns, general ecology, and the ecological significance of certain rabbit species to golden eagles across the Western United States. The results of this work can be incorporated into monitoring plans for golden eagles and their habitats and can be used as inputs to ecological models of eagle populations as the work advances.

\section{Contacts}

Todd Esque, USGS Western Ecological Research Center, tesque@usgs.gov, (702) 564-4506

Kathleen Longshore, USGS Western Ecological Research Center,

longshore@usgs.gov, (702) 564-4505

\section{Publications}

Longshore, K.M., Esque, T.C., Nussear, K.E.,

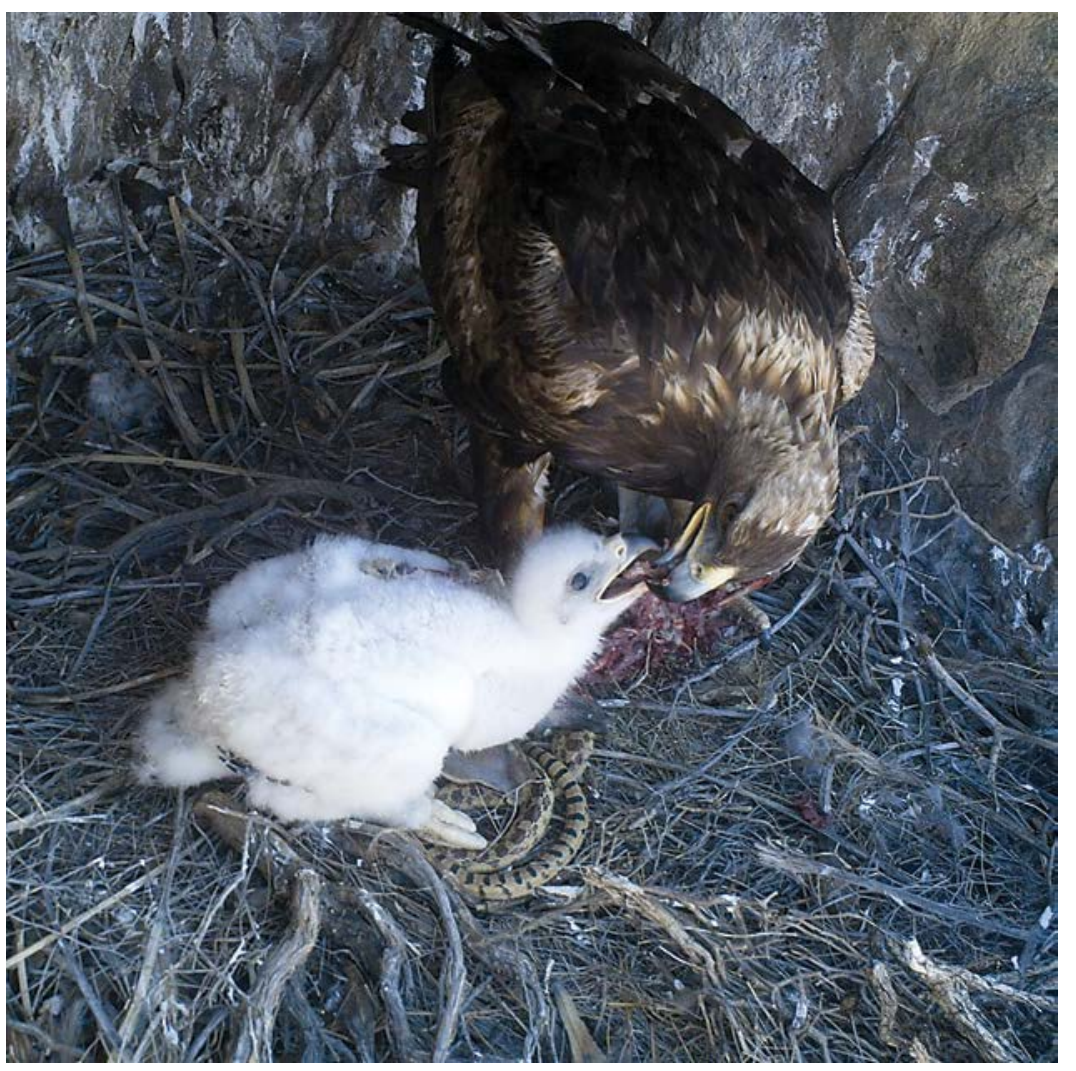

Golden eagle feeding a chick in its nest on a cliff near Victorville, California.

Johnson, Diego, Simes, Matthew, and

Inman, R.D., 2017, An assessment of food habits, prey availability, and nesting success of golden eagles within the Desert Renewable Energy Conservation Plan Area: Prepared for California Energy Commission, Publication Number CEC-5002017-003, 57 p., accessed September 5, 2017, at https://pubs.er.usgs.gov/publication/70190366.

Simes, Matthew, Johnson, Diego, Streit, Justin, Longshore, Kathleen, Nussear, K.E., and Esque, T.C., 2017, Common raven (Corvus corax) kleptoparasitism at golden eagle (Aquila chrysaetos) nest in southern Nevada: The Wilson Journal of Ornithology, v. 129, no. 1, p. 195-198, https://doi.org/10.1676/1559-4491-129.1.195.

U.S. Geological Survey, 2016, Mojave golden eagles [Stephen M. Wessells, producer; Justin Louis, narrator]: U.S. Geological Survey video, 5:13 min., https://www.youtube.com/watch?v=6s-e_utRMDY.

Simes, M.T., Longshore, K.M., Nussear, K.E., Beatty, G.L., Brown, D.E., and Esque, T.C., 2015, Black-tailed and white-tailed jackrabbits in the American West-History, ecology, ecological significance, and survey methods: Western North American Naturalist, v. 75, no. 4, p. 491-519, https://doi.org/10.3398/064.075.0406. 


\section{Golden Eagles in New Mexico}

The BLM manages large areas in New Mexico that have a high potential for wind energy development. USGS science is helping assess the risk that proposed wind energy developments in southeastern and south-central New Mexico may have on resident and migratory golden eagles. The study is planned to assess habitat and space use of migratory and resident golden eagles; identify nest sites; estimate productivity and survival, origin, and migration patterns; and determine factors affecting golden eagle distribution. Results of the study may be used to inform the development of mitigation strategies that can reduce potential negative effects from proposed wind energy developments.

\section{Contact}

James Cain, USGS New Mexico Cooperative Fish and Wildlife Research Unit, jwcain@usgs.gov, (575) 646-3382

\section{Wintering Distribution of Golden Eagles in the Southern Great Plains}

1 The Southern Great Plains, which comprises eastern New Mexico and the panhandles of Oklahoma and Texas, is experiencing rapid wind energy development. The region has traditionally been an important wintering area for golden eagles. The USGS is assessing the distribution and abundance of wintering golden eagles in relation to land-cover and land-use types across this region. The results of this study can provide industry managers with insight into whether landscape features pose potential conflicts between wind energy development and eagles.

\section{Contact}

Clint Boal, USGS

Texas Cooperative Fish and Wildlife Research Unit, cboal@usgs.gov,

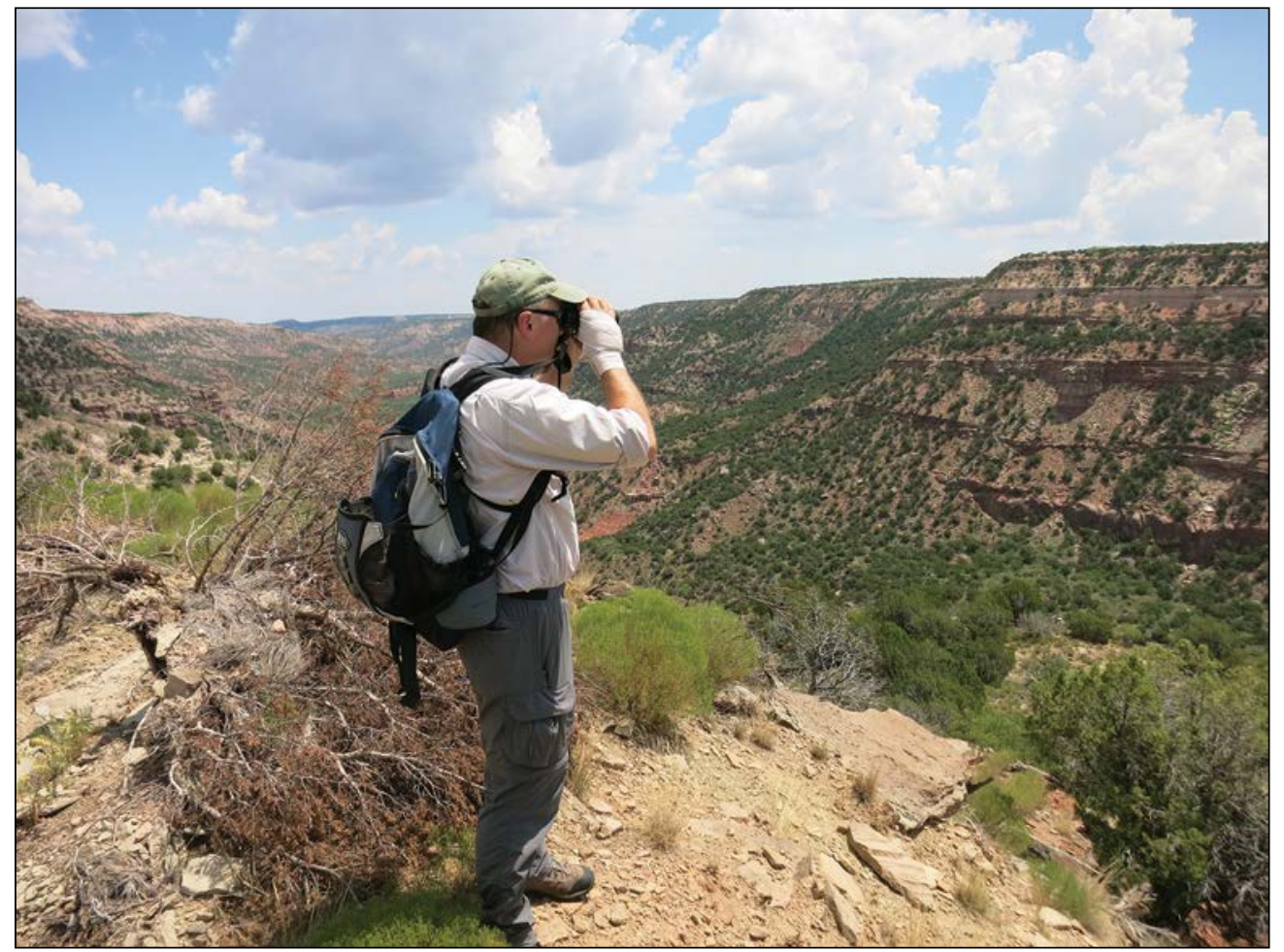

Dr. Clint Boal, Texas Cooperative Fish and Wildlife Research Unit, observing a golden eagle nest in the caprock canyon country of west Texas.

\section{Tracking Bald Eagles Near Wind Energy Facilities in the Central Great Plains}

The Central Great Plains is an important focus area for the development of new wind facilities. The USGS is leading an effort to track bald eagles using GPS-GSM telemetry to acquire information that will help wildlife managers address potential conflict between bald eagles and wind turbines in Oklahoma and collaborate on similar work in Iowa and Illinois. Scientists are collecting information on topography, weather, and land cover to understand how environmental conditions may put eagles at risk from collisions with turbines.

\section{Contact}

Todd Katzner, USGS Forest and Rangeland Ecosystem Science Center, tkatzner@usgs.gov, (208) 426-5232 


\section{Condor Flight Behavior Near Wind Energy Facilities}

California condor populations face numerous threats, including the development of wind energy facilities. Scientists from the USGS, USFWS, California Department of Fish and Wildlife, and BLM are tracking condor flight using high-frequency GPS-GSM telemetry to understand how flight behavior alters the risk for condors to interact with wind turbines. Project scientists plan to record movements of California condors to understand how their flight behavior, especially flight altitude, responds to variation in topography and weather. This information can be used to identify wind and topographic variables that may be preferentially used by condors and to predict risk to birds from existing and proposed turbines.

\section{Contact}

Todd Katzner, USGS Forest and Rangeland Ecosystem Science Center, tkatzner@usgs.gov, (208) 426-5232

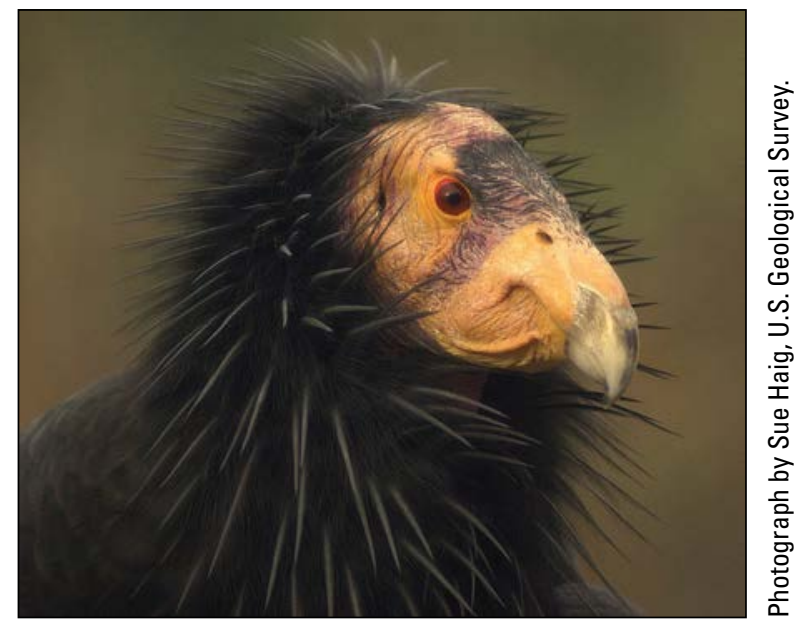

California condor at the Portland Zoo.

\section{Measure Impacts}

\section{Population Demography of Golden Eagles Near the Altamont Pass Wind Resource Area, 1 California}

Wind turbines at the Altamont Pass Wind Resource Area in California have been estimated to kill as many as 28 to 68 golden eagles annually. This study investigates how estimated levels of turbine-related mortality and other environmental stressors may interact to affect the population demography of golden eagles in the broader landscapes surrounding the wind farm. The USGS and partners are using historic and current eagle data to assess territory occupancy, abundance, breeding success, survival, and habitat use of different age classes of golden eagles. This information has been used to quantify how the local population of golden eagles may respond to observed levels of turbine-related fatalities. Additionally, results from this study are providing detailed information on specific sites or breeding areas that contribute most to overall population growth, which permits land managers to identify and prioritize important areas for conservation.

\section{Contact}

David Wiens, USGS Forest and Rangeland Ecosystem Science Center, jwiens@usgs.gov, (541) 750-0961

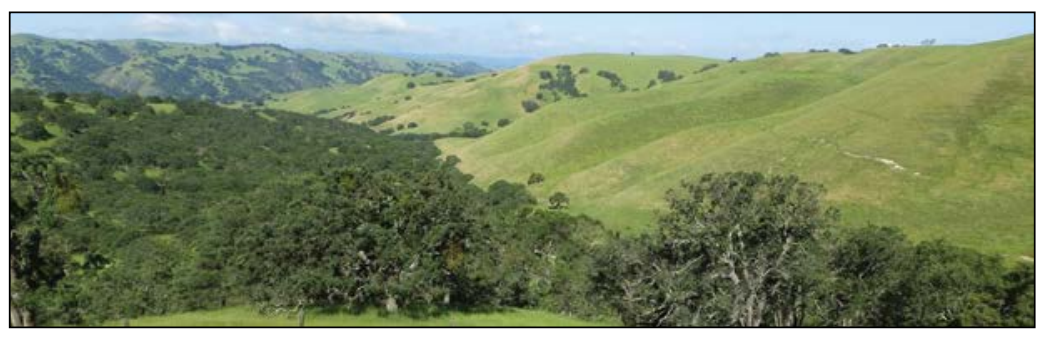

High-quality nesting habitat for golden eagles in the Diablo Range, California (from Hunt and others, 2017).

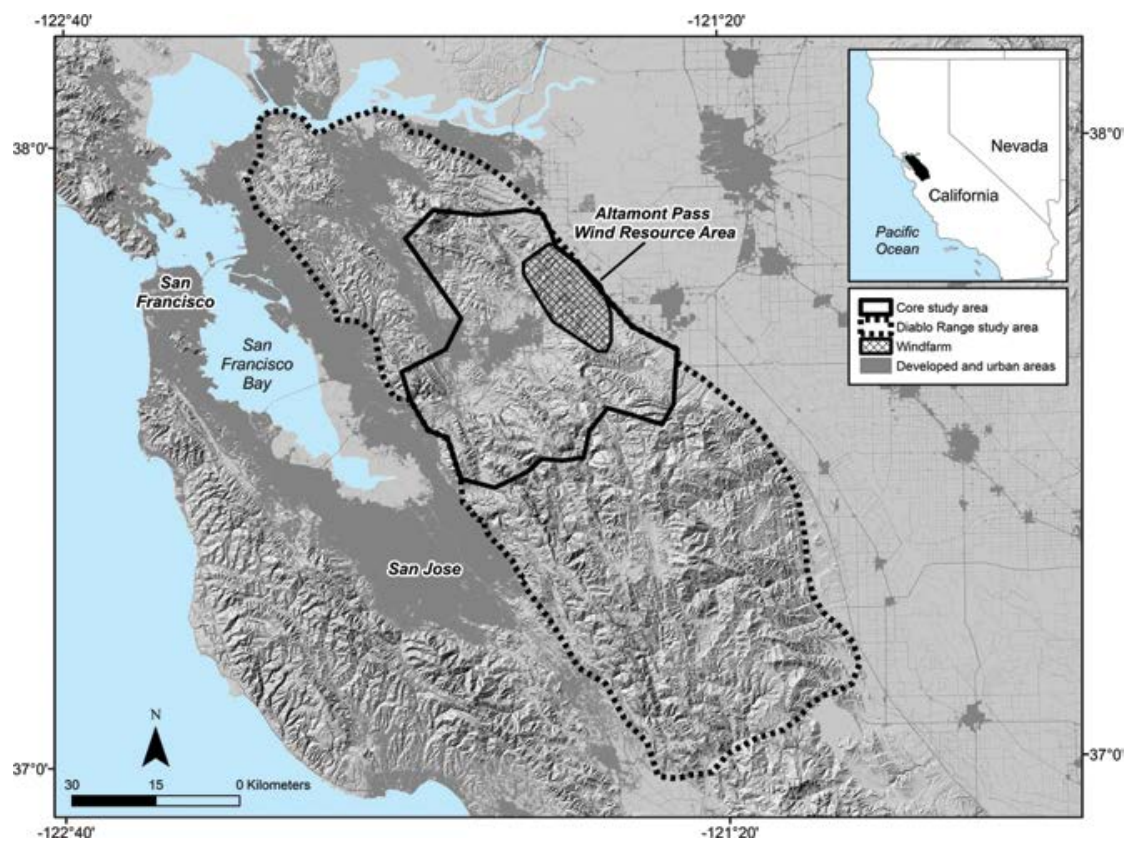

Location of the Altamont Pass Wind Resource Area in the Diablo Range, California (from Hunt and others, 2017). 


\section{Publications}

Hunt, W.G., Wiens, J.D., Law, P.R., Fuller, M.R., Hunt, T.L., Driscoll, D.E., and Jackman, R.W., 2017, Quantifying the demographic cost of human-related mortality to a raptor population: PLOS ONE, v. 12, no. 2, e0172232, https://doi.org/10.1371/journal.pone.0172232.

Kolar, P.S., and Wiens, J.D., 2017, Distribution, nesting activities, and age-class of territorial pairs of golden eagles at the Altamont Pass Wind Resource Area, California, 2014-16: U.S. Geological Survey Open-File Report 2017-1035, 18 p., https://doi.org/10.3133/ofr20171035.

Wiens, J.D., Kolar, P.S., Fuller, M.R., Hunt, W.G., and Hunt, Teresa, 2015, Estimation of occupancy, breeding success, and abundance of golden eagles (Aquila chrysaetos) in the Diablo Range, California, 2014: U.S. Geological Survey Open-File Report 2015-1039, 23 p., https://doi.org/10.3133/ofr20151039.

\section{Using Drones to Detect Golden Eagle 1 Carcasses}

The USGS, in collaboration with Oregon State University and the Confederated Tribes of Warm Springs, is investigating the use of unmanned aircraft systems, or drones, to detect golden eagle carcasses at wind energy facilities. The objectives of the investigation are to use change-detection software to compare ground images taken by drones on separate flights over time to detect the timing of carcass appearance and to evaluate whether detection is affected by vegetation or carcass size.

\section{Contact}

Manuela Huso, USGS Forest and Rangeland Ecosystem Science Center, mhuso@usgs.gov, (541) 750-0948
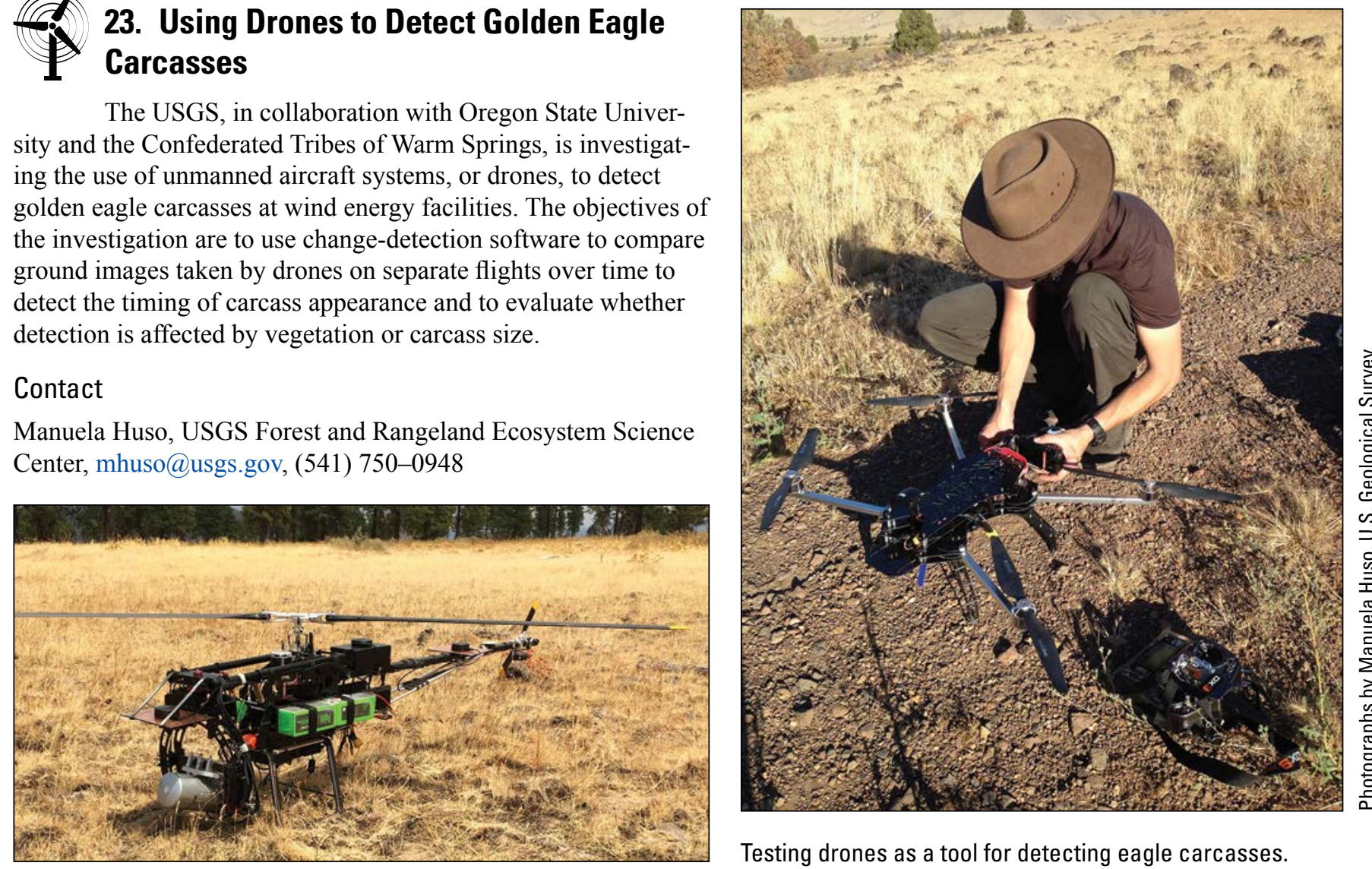

Testing drones as a tool for detecting eagle carcasses.

\section{Inform Solutions}

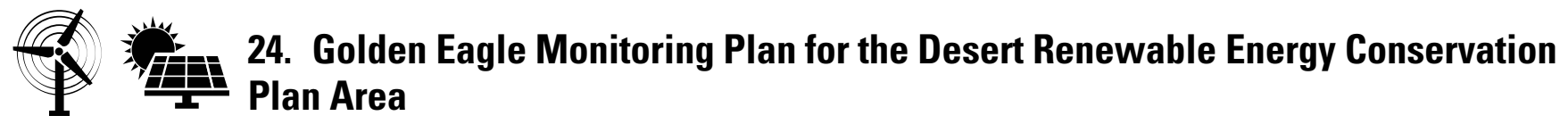

The Desert Renewable Energy Conservation Plan (DRECP) was developed to provide protection of Mojave and Colorado Desert ecosystems while allowing for the appropriate development of renewable energy projects. Research and monitoring of golden eagles are suggested to ensure that biological goals of the DRECP will be achieved while promoting compatible renewable energy development. The USGS and partners developed a research and monitoring plan for the DRECP that (a) profiles the ecology and status of golden eagles and their habitats in the area, (b) provides a range of potential sampling options to address monitoring needs, and (c) characterizes an iterative approach to monitoring golden eagles focusing on links between changes in human land-use, nesting, and foraging habitat conditions and population dynamics. The monitoring plan outlines a process for collecting and analyzing data on territory occupancy, reproduction, survival, and population size that can provide regulatory agencies with information to make conservation policy decisions regarding permitting and siting of renewable energy projects. 


\section{Contact}

David Wiens, USGS Forest and Rangeland Ecosystem Science Center, jwiens@usgs.gov, (541) 750-0961

\section{Publication}

Wiens, J.D., Schumaker, N.H., Inman, R.D., Esque, T.C., Longshore, K.M., and Nussear, K.E., 2017, Spatial demographic models to inform conservation planning of golden eagles in renewable energy landscapes: Journal of Raptor Research, v. 51, no. 3, p. 234-257, https://doi.org/10.3356/JRR-16-77.1.

\section{Eagle Surveys, Monitoring, and Distribution}

The USGS reviewed the utility of the recommended golden eagle survey methodology given in the 2013 USFWS Eagle Conservation Plan Guidance with a goal of assessing the influence of different survey time intervals, sampling periods, and landscapes on detectability and occupancy estimates of golden eagles. Repeat 800-meter radius, 1-hour point-count surveys were conducted during two sampling periods at 50 sample points in three areas over breeding seasons in north-central New Mexico and southwestern Idaho during 2012 and 2013, and in southwestern Wyoming during 2013. A total of 1,500 hours of survey data were evaluated to determine the level of survey effort necessary to adequately evaluate eagle occurrence depending on area, season, and year. This study can help inform the temporal and spatial effort necessary to improve the efficacy of point-count surveys in evaluating golden eagle occurrence.

\section{Contact}

Clint Boal, USGS Texas Cooperative Fish and Wildlife Research Unit, cboal@usgs.gov, (806) 834-6536

\section{Publication}

Skipper, B.R., Boal, C.W., Tsai, J.-S., and Fuller, M.R., 2017, Assessment of frequency and duration of point counts when surveying for golden eagle presence: Wildlife Society Bulletin, v. 41, no. 2, p. 212-223, https://doi.org/10.1002/wsb.770.

\section{Golden Eagle Late-Summer Occupancy in Wyoming}

The USGS is developing golden eagle habitat-occupancy models to overlay with maps of potential energy development, including wind energy in Wyoming and other parts of the Western United States. Models and maps can be used to highlight biological strengths and weaknesses, or high- and low-quality habitat, across the landscape. Map overlays explicitly delineate opportunities for conservation - areas of high quality habitat where the energy-generating potential is low — and imminent threats - areas of high-quality habitat where the energy-generating potential is high. These tools can assist resource managers in their efforts with industry concerning siting for energy development and the identification of areas for off-site mitigation.

\section{Contact}

Zachary Bowen, USGS Fort Collins Science Center, bowenz@usgs.gov, (970) 226-9218

\section{Publications}

Tack, J.D., Noon, B.R., Bowen, Z.H., Strybos, Lauren, and Fedy, B.C., 2017, No substitute for survival—Perturbation analyses using a golden eagle population model reveals limits to managing for take: Journal of Raptor Research, v. 51, no. 3 , p. 258-272, https://doi.org/10.3356/JRR-16-32.1.

Tack, J.D., and Fedy, B.C., 2015, Landscapes for energy and wildlife - Conservation prioritization for golden eagles across large spatial scales: PLOS ONE, v. 10, no. 8, e0134781, https://doi.org/10.1371/journal.pone.0134781.

\section{Predicting Golden Eagle Fatalities at Wind Facilities}

The USGS, working with USFWS, has developed a predictive Bayesian Collision Risk Model (CRM) of golden eagle "take" at a given wind facility. The model is based on preconstruction eagle-use surveys and design considerations. The USFWS uses the model to work with facility applicants at the design and permitting stages to generate a predicted number of eagle fatalities for an incidental take permit. This model serves as the basis for compensatory mitigation, which may be needed. Scientists are also helping develop eagle population models at the regional level to evaluate the effect of the cumulative take on population 
dynamics. Both efforts explicitly acknowledge uncertainty and, by doing so, permit risk analysis and the implementation of adaptive management.

\section{Contact}

Michael Runge, USGS Patuxent Wildlife Research Center, mrunge@usgs.gov, (301) 497-5748

\section{Publication}

New, Leslie, Bjerre, Emily, Millsap, Brian, Otto, M.C., and Runge, M.C., 2015, A collision risk model to predict avian fatalities at wind facilities-An example using golden eagles, Aquila chrysaetos: PLOS ONE, v. 10, no. 7, e0130978, https://doi.org/10.1371/journal.pone.0130978.

\section{Habitat Prioritization for Wyoming Raptors in Wyoming}

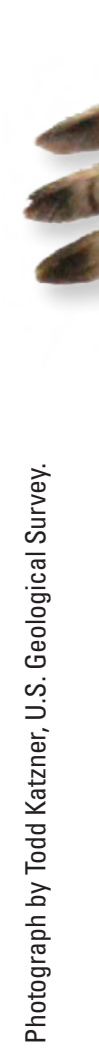

The USGS is leading a project to develop predictive models of the association between the available habitat of raptors, such as golden eagle, ferruginous hawk, northern harrier, and prairie falcon, and their habitat use in Wyoming. This project is planned to create models and maps that can be used to identify priority habitat areas and assist resource managers with raptor conservation by providing information that can be used in the siting of wind power infrastructure and prioritization of locations for strategic and focused conservation efforts.

\section{Contact}

Zachary Bowen, USGS Fort Collins Science Center, bowenz@usgs.gov, (970) 226-9218

Ferruginous hawk in flight.

\section{Potential Interactions of Migrating Raptors and Wind Energy Sites at the International Scale}

Swainson's hawks are long-distance migratory raptors that breed across Western North America and migrate to Argentina for the winter. This annual round trip of approximately 20,000 kilometers (12,500 miles) takes the hawks over 12 countries, which all have interests in wind energy development. The USGS is using GPS transmitters to determine precise migration routes, which are then overlaid on maps of wind energy potential. This provides the means to identify high-risk areas for migrating raptors at the international scale. Analysis of 3 years of data for adult hawks is underway, and field data collection is now being shifted to include young hawks.

\section{Contact}

Clint Boal, USGS Texas Cooperative Fish and Wildlife Research Unit, cboal@usgs.gov, (806) 742-2851 


\section{Additional Publications About Raptors}

Mallon, J.M., Bildstein, K.L., and Katzner, T.E., 2016, In-flight turbulence benefits soaring birds: The Auk, v. 133, no. 1, p. 79-85, https://doi.org/10.1642/auk-15-114.1.

Braham, Melissa, Miller, Tricia, Duerr, A.E., Lanzone, Michael, Fesnock, Amy, LaPre, Larry, Driscoll, Daniel, and Katzner, Todd, 2015, Home in the heat-Dramatic seasonal variation in home range of desert golden eagles informs management for renewable energy development: Biological Conservation, v. 186, p. 225-232, https://doi.org/10.1016/j.biocon.2015.03.020.

Jachowski, D.S., Katzner, Todd, Rodrigue, J.L., and Ford, W.M., 2015, Monitoring landscape-level distribution and migration phenology of raptors using a volunteer camera-trap network: Wildlife Society Bulletin, v. 39, no. 3, p. 553-563, https://doi.org/10.1002/wsb.571.

Rivers, J.W., Johnson, J.M., Haig, S.M., Schwarz, C.J., Burnett, L.J., Brandt, Joseph, George, Daniel, and Grantham, Jesse, 2014, An analysis of monthly home range size in the critically endangered California Condor Gymnogyps californianus: Bird Conservation International, v. 24, no. 4, p. 492-504, https://doi.org/10.1017/s0959270913000592.

Rivers, J.W., Johnson, J.M., Haig, S.M., Schwarz, C.J., Burnett, L.J., Brandt, Joseph, George, Daniel, and Grantham, Jesse, 2014, An analysis of monthly home range size in the critically endangered California Condor Gymnogyps californianusCORRIGENDUM: Bird Conservation International, v. 25, no. 2, p. 258, https://doi.org/10.1017/s0959270915000039.

Tracey, J.A., Sheppard, James, Zhu, Jun, Wei, Fuwen, Swaisgood, R.R., Fisher, R.N., and Sueur, Cédric, eds., 2014, Movementbased estimation and visualization of space use in 3D for wildlife ecology and conservation: PLOS ONE, v. 9, no. 7, e101205, https://doi.org/10.1371/journal.pone.0101205.
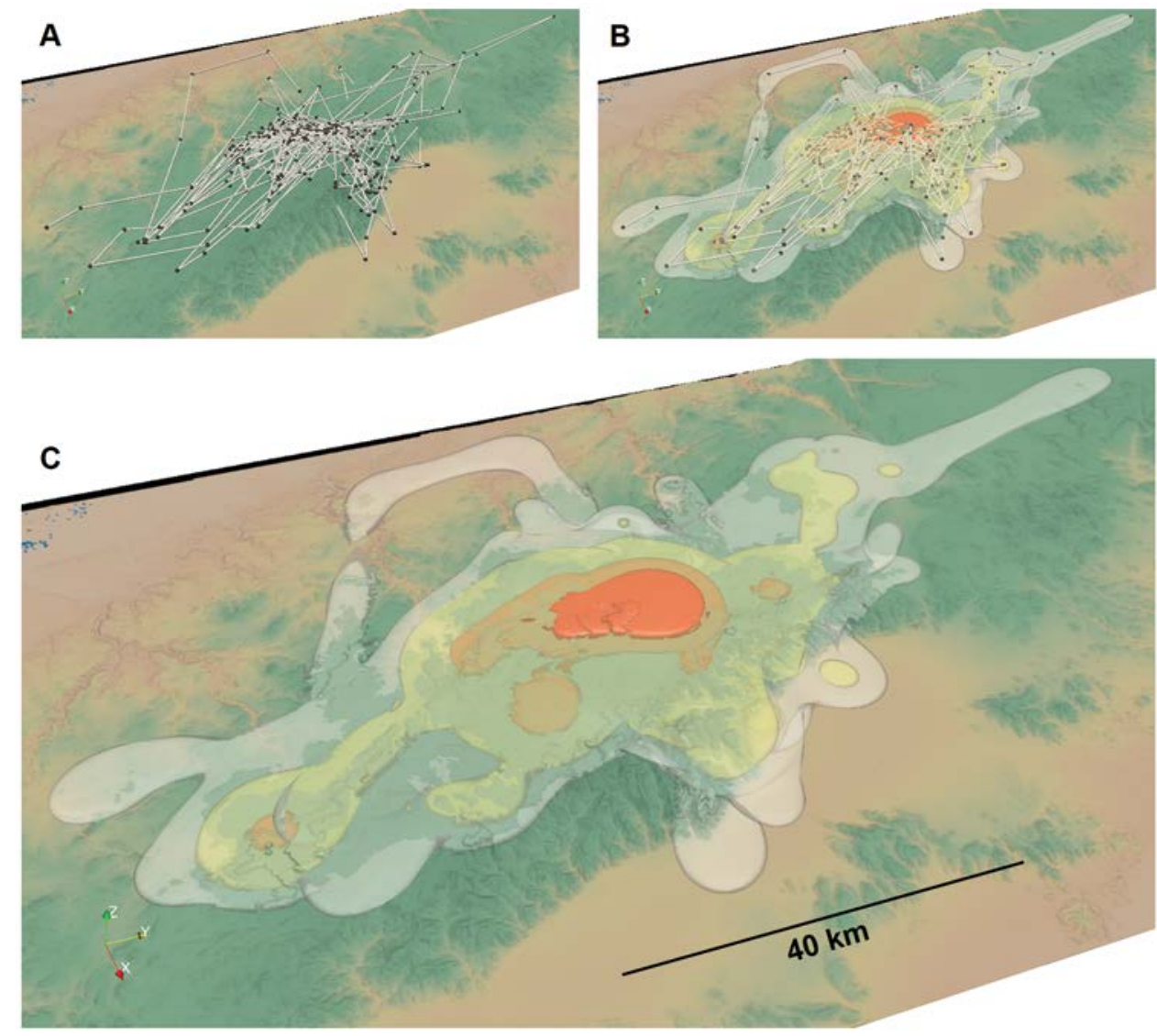

A movement-based kernel density estimator and computer visualization showing 3D home range for a California condor (from Tracey and others, 2014). 


\section{Great Lakes, Coastal, and Marine Birds}

\section{Atlantic Ocean}

\section{Potential Impacts of Offshore Wind Energy Projects on Endangered Roseate Terns}

Offshore wind energy projects have been permitted for two coastal areas in Massachusetts and Rhode Island and have been proposed for offshore areas of New York. Fish-eating terns traveling through these offshore areas could be impacted by the construction and operation of wind turbines. The "Cape and Islands" area of southeastern Massachusetts is a particularly important area for the endangered northwest Atlantic roseate tern population because most of these terns congregate in this area for several months during the postbreeding staging period prior to fall migration. USGS scientists will examine long-term temporal variation in staging site use and survival of terns prior to the construction of offshore wind turbine operations. These data could be useful for evaluating the timing or risks to roseate terns from proposed offshore wind energy projects.

\section{Contact}

Jeffrey Spendelow, USGS Patuxent Wildlife Research Center, jspendelow@usgs.gov, (301) 497-5665

\section{Publications}

Spendelow, J.A., in press, Rapid 3-week transition from migration to incubation in a female Roseate Tern (Sterna dougallii): North American Bird Bander, v. 42.

Spendelow, J.A., and Lugo, Gabriel, in press, First evidence that paired Roseate Terns travel together during spring migration: North American Bird Bander, v. 42.

Nichols, J.M., Spendelow, J.A., and Nichols, J.D., 2017, Using optimal transport theory to estimate transition probabilities in metapopulation dynamics: Ecological Modelling, v. 349, p. 311-319, https://doi.org/10.1016/j.ecolmodel.2017.06.003.

Althouse, M.A., Cohen, J.B., Spendelow, J.A., Karpanty, S.M., Davis, K.L., Parsons, K.C., and Luttazi, C.F., 2016, Quantifying the effects of research band resighting activities on staging terns in comparison to other disturbances: Waterbirds, v. 39, no. 4, p. 415-419, https://doi.org/10.1675/063.039.0412.

Nisbet, I.C.T., Monticelli, David, Spendelow, J.A., and Szczys, Patricia, 2016, Pre-breeding survival of Roseate Terns Sterna dougallii varies with sex, hatching order and hatching date: Ibis, v. 158, no. 2, p. 327-334, https://doi.org/10.1111/ibi.12359. 


\section{Evaluating Acoustic Sensitivity of Diving Birds to Offshore Energy Development Activities}

Construction and maintenance of wind turbines can increase in-air and underwater noise levels from pile driving, shipping of materials, turbine operation, and other activities. The USGS is testing whether diving bird species rely on auditory cues to orient or forage, by measuring in-air auditory thresholds in diving bird species, using behavioral and electrophysiological (auditory brainstem response $[\mathrm{ABR}]$ ) techniques. At present these methodologies are being replicated in the underwater environment on long-tailed ducks, a pursuit diver of fish, and lesser scaup, which forage on sessile prey. These data may be the first evaluation of underwater hearing abilities of diving birds with the ultimate goal of evaluating the impacts of underwater noise activities on these species.

\section{Contact}

Alicia M. Berlin, USGS Patuxent Wildlife Research Center, aberlin@usgs.gov, (301) 497-5730

\section{Publication}

Crowell, S.E., Wells-Berlin, A.M., Carr, C.E., Olsen, G.H., Therrien, R.E., Yannuzzi, S.E., and Ketten, D.R., 2015, A comparison of auditory brainstem responses across diving bird species: Journal of Comparative Physiology A, v. 201, no. 8, p. 803-815, https://doi.org/10.1007/s00359-015-1024-5.

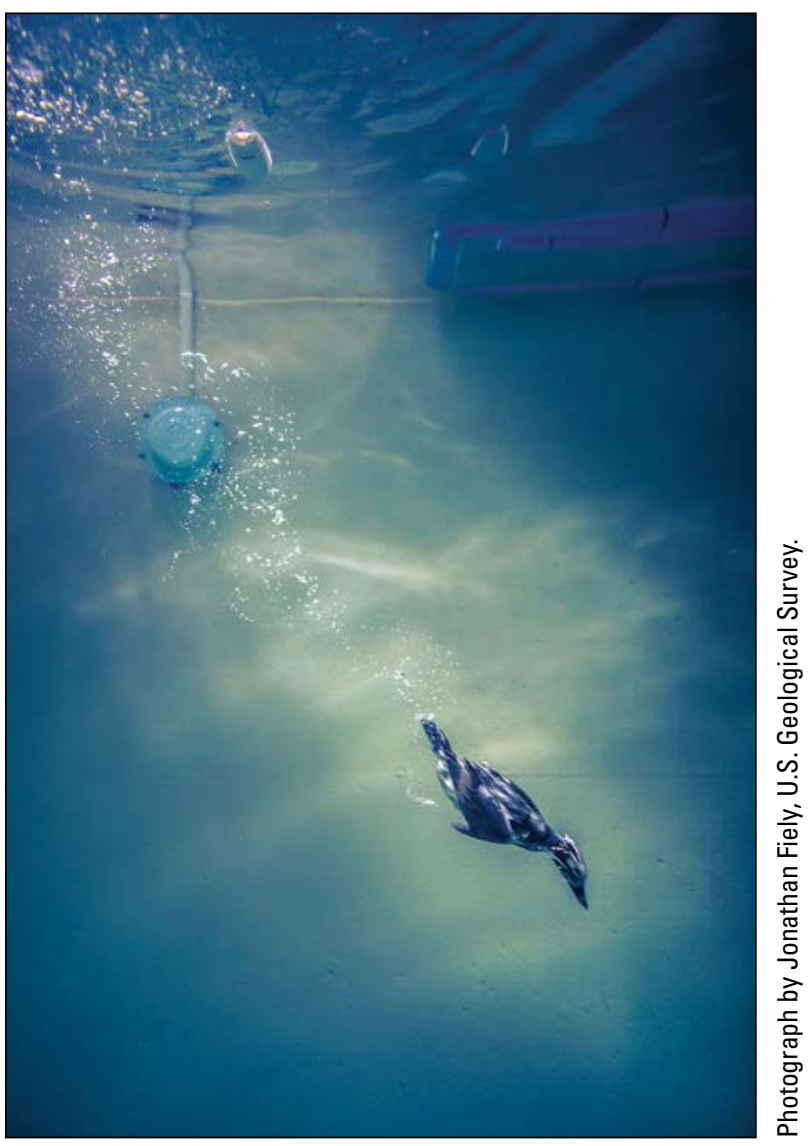

Diving long-tailed duck during hearing trials.

\section{Satellite Tracking Offshore Habitat Use in Diving Bird Species}

USGS scientists are using platform terminal transmitter satellite tracking tags to determine the occurrence and local movement patterns of red-throated loons, surf scoters, and northern gannets in Federal waters of the mid-Atlantic region of the United States during migration and winter. From 2012 to 2016, scientists tracked the movements of 75 gannets and 66 loons, and from 2001 to 2016 , scientists tracked 217 scoters on their northward migration to their breeding colonies and on their southward migration back to and through the midAtlantic region. When published, data can inform siting, permitting, and regulation of future offshore wind development and provide important information on key habitat use and migration of a suite of species with different ecological niches.

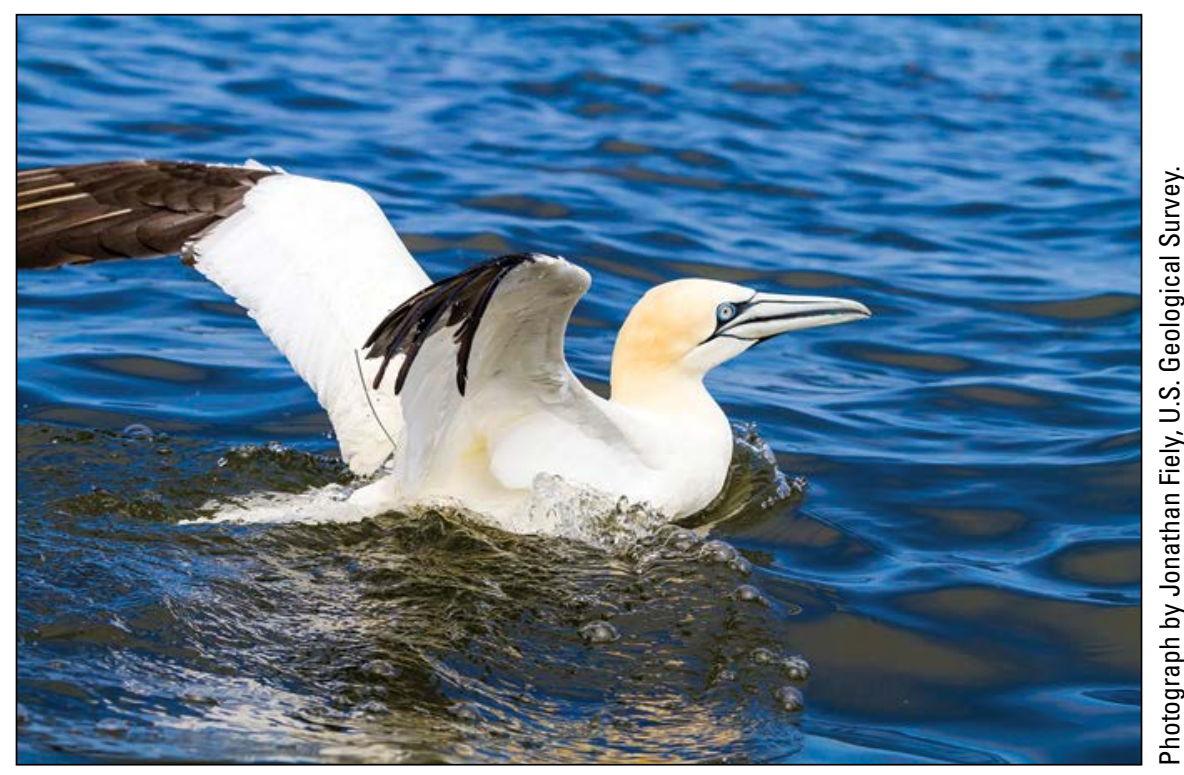

Northern gannet with a satellite tracking antenna.

\section{Contact}

Alicia M. Berlin, USGS Patuxent Wildlife Research Center, aberlin@usgs.gov, (301) 497-5730 


\section{External GPS-GSM-Based Transmitters for Tracking Seabirds}

USGS scientists are testing solar-powered GPS-GSM-based transmitters on seabirds to provide data with the necessary precision to capture fine-scale movement patterns. This new information may allow them to better relate the influence of weather, resource availability, and hazardous conditions for seabirds and thus predict conflict with offshore wind power facilities along the Atlantic coast. Preliminary data have corroborated previous platform terminal transmitter tracking data from these species and are also providing preliminary altitudinal data. The deployment of additional transmitters can be instrumental in modeling habitat use, mortality risk, and the impact of weather on flight behavior for these species in the face of multiple proposed offshore wind facilities along the Atlantic coast.

\section{Contact}

Alicia M. Berlin, USGS Patuxent Wildlife Research Center, aberlin@usgs.gov, (301) 497-5730
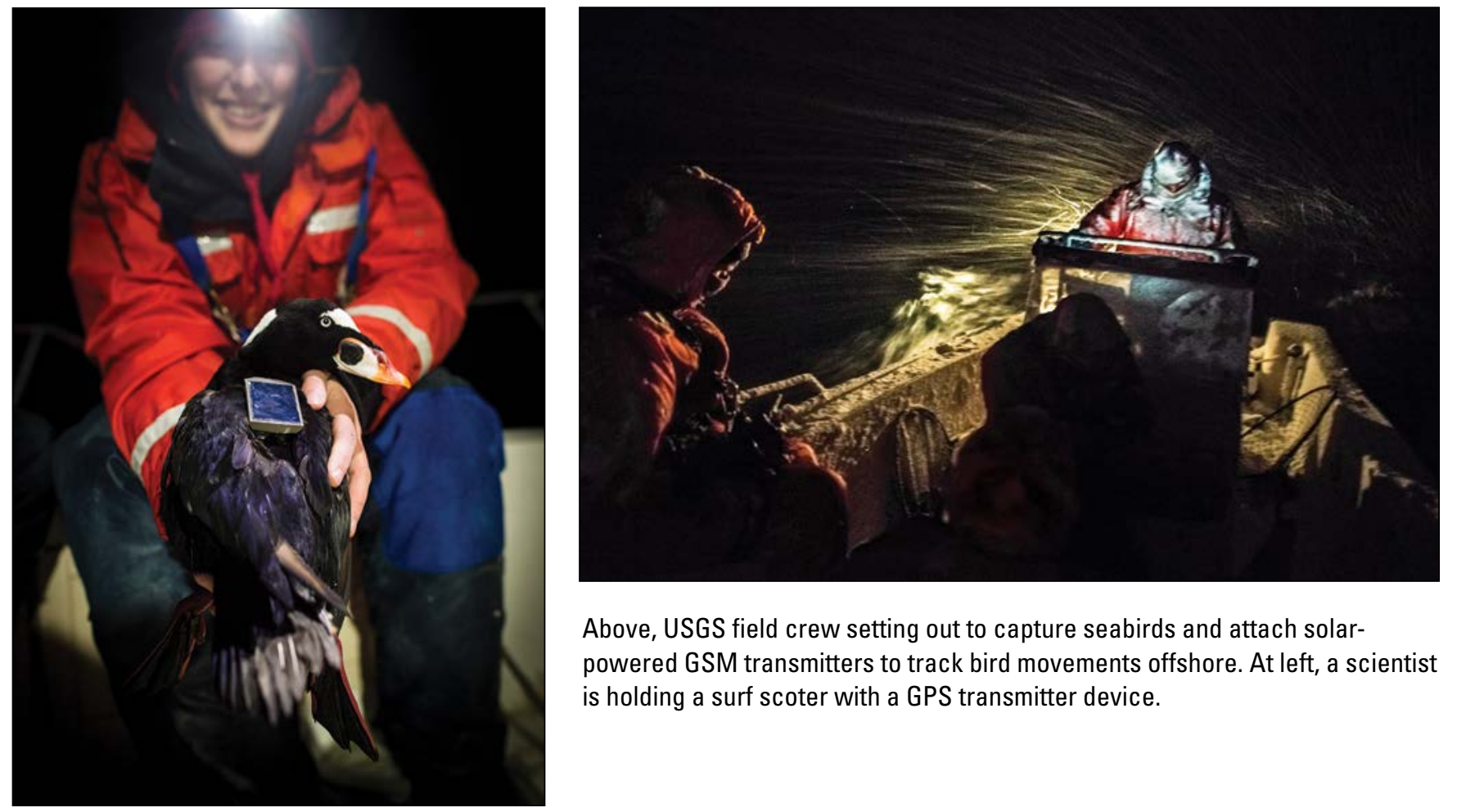

Above, USGS field crew setting out to capture seabirds and attach solarpowered GSM transmitters to track bird movements offshore. At left, a scientist is holding a surf scoter with a GPS transmitter device.

\section{The Atlantic Offshore Seabird Dataset Catalog}

To assess the impacts of alternative energy on marine bird populations, large amounts of occurrence information are required along with biophysical data that influence species distributions. Before a model is constructed, data need to be retrieved, reconfigured, synthesized, and vetted. USGS scientists have created a catalog of more than 100 datasets, developed computer programs to facilitate comparisons between historic and recent surveys, and standardized survey sampling efforts for the Atlantic Outer Continental Shelf. This database is the single largest repository of marine bird information available for the western Atlantic. It includes information dating back to the 1970s and more than 350,000 seabird occurrence records from Florida to Maine, and one from Atlantic Canada.

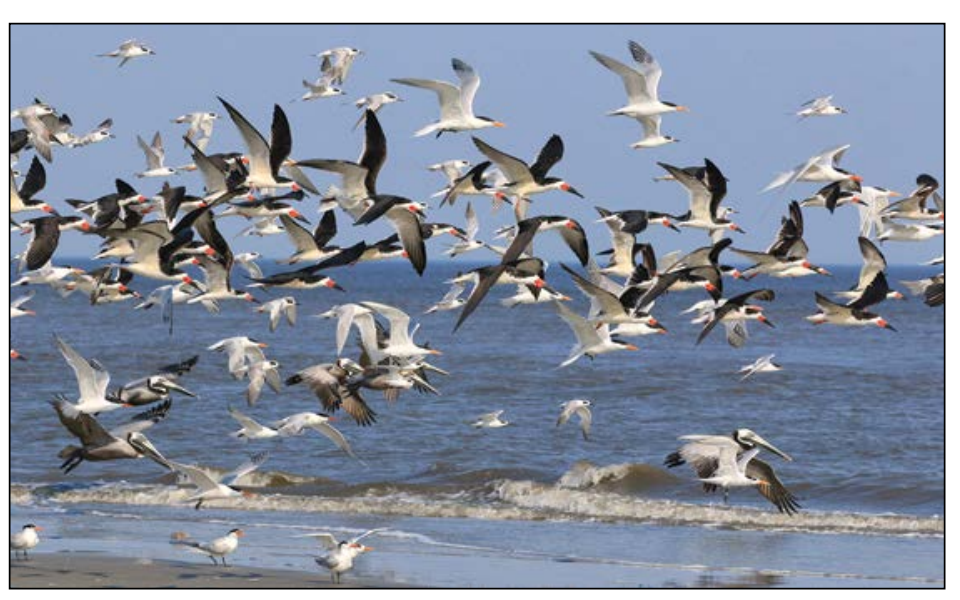

A variety of shore birds frequent Jekyll Island, Georgia. 


\section{Contact}

Mark Wimer, USGS Patuxent Wildlife Research Center, mwimer@usgs.gov, (301) 497-5596

\section{Publication}

Wimer, Mark, and Benson, Abigail, 2016, USGS Patuxent Wildlife Research Center Seabirds Compendium, v. 1.1:

U.S. Geological Survey occurrence dataset, https://doi.org/10.15468/w2vk7x.

\section{Modeling of Atlantic Coast Seabird Distributions}

To better understand the potential impacts of offshore energy development on Atlantic seabirds, the USGS initially used occurrence information from the Atlantic Seabird Compendium to develop hierarchical models and assess the distribution of marine avian populations. With the recent availability of robust survey information (repeat surveys), the USGS has developed dynamic occupancy models to refine those initial models and assess how seabird distributions vary over time and space. This effort is helping develop effective tools for estimating seabird habitat and distributions that can be used to inform siting of offshore energy development.

\section{Contact}

Allan O’Connell, USGS Patuxent Wildlife Research Center, aoconnell@usgs.gov, (301) 497-5525

\section{Publication}

Flanders, N.P., Gardner, Beth, Winiarski, K.J., Paton, P.W.C., Taber, Allison, and O'Connell, A.F., 2015, Key seabird areas in southern New England identified using a community occupancy model: Marine Ecology Progress Series, v. 533, p. 277-290, https://doi.org/10.3354/meps11316.

\section{Pacific Ocean}

\section{Southern California Marine Bird and Mammal Surveys}

The Southern California Bight (SCB) and the Pacific Outer Continental Shelf (PacOCS) biome off the central coast of California is the only region in California that supports breeding black storm-petrels, brown pelicans, Scripps's murrelets, and elegant terns. The area also contains nearly half of the world population of endemic ashy storm-petrels. The USGS plans to repeat aerial surveys to provide up-to-date information and a more robust longitudinal dataset from which to draw on for environmental analyses on the potential effects from proposed offshore energy development to seabirds and marine mammals. The study expects to (1) update understanding of the status and distribution of seabirds and marine mammals in areas where renewable energy projects may be proposed, (2) relate this new information to past surveys, and (3) augment data for numerically abundant and (or) indicator species, important area breeding and migratory species, and species with greatest vulnerability to offshore renewable energy development.

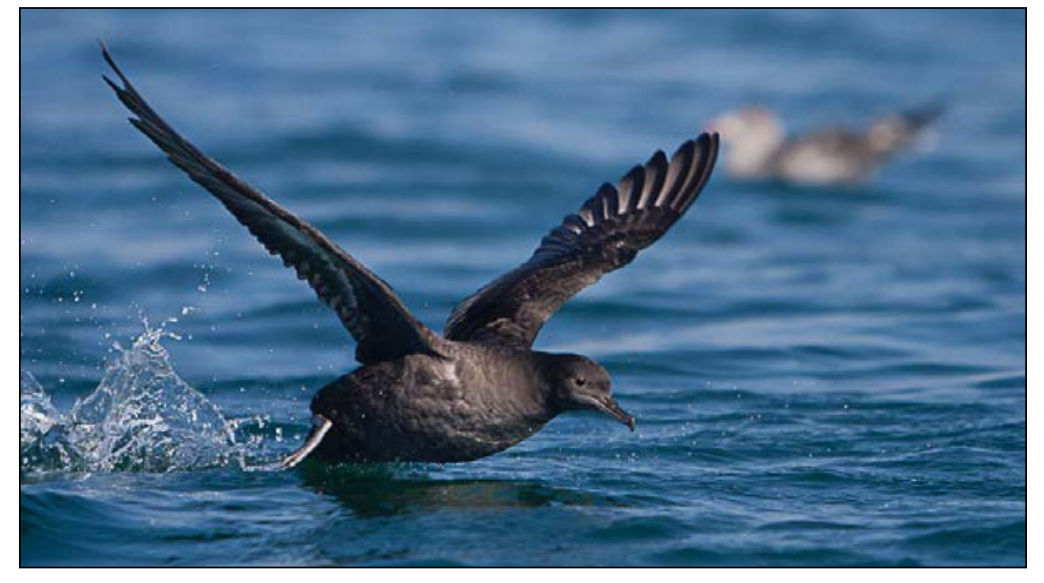

A sooty shearwater takes off just offshore of Capitola, California.

\section{Contact}

Josh Adams, USGS Western Ecological Research Center, josh_adams@usgs.gov, (831) 460-7566

\section{Publications}

Adams, Josh, Kelsey, E.C., Felis, J.J., and Pereksta, D.M., 2017, Collision and displacement vulnerability among marine birds of the California Current System associated with offshore wind energy infrastructure (ver. 1.1, July 2017): U.S. Geological Survey Open-File Report 2016-1154, 116 p., https://doi.org/10.3133/ofr20161154. 
Adams, Josh, Felis, J.J., Mason, J.W., and Takekawa, J.Y., 2015, Pacific Continental Shelf Environmental Assessment (PaCSEA) GIS resource database-Aerial seabird and marine mammal surveys off northern California, Oregon, and Washington, 2011-2012: U.S. Geological Survey data release, https://doi.org/10.5066/F7668B7V.

Adams, Josh, Felis, J.J., Mason, J.W., and Takekawa, J.Y., 2014, Pacific Continental Shelf Environmental Assessment (PaCSEA)-Aerial seabird and marine mammal surveys off northern California, Oregon, and Washington, 2011-2012-Data summary: Camarillo, Calif., Bureau of Ocean Energy Management, U.S. Department of the Interior, OCS Study BOEM 2014-003, 266 p., https://www.sciencebase.gov/catalog/item/55773437e4b032353cba3080.

\section{Predictive Modeling of Marine Bird Spatial Distributions on the Pacific Outer Continental Shelf}

The States of California, Oregon, and Washington are engaged with the BOEM in various ways to plan the siting of offshore energy projects within the territorial sea and OCS regions. The USGS and collaborators are using at-sea transect survey and individual tracking data throughout the PacOCS in addition to oceanographic and environmental data to develop predictive models on distribution and abundance and hotspot/coldspot areas and relative bird occurrence and abundance throughout a large region of the California Current System.

\section{Contact}

Josh Adams, USGS Western Ecological Research Center, josh_adams@usgs.gov, (831) 460-7566

\section{Main Hawaiian Islands Seabird Tracking}

The main Hawaiian Islands and associated offshore areas provide substantial breeding habitat for more than 19 seabird species. The BOEM and the State of Hawai' $\mathrm{i}$ have received proposals to develop offshore renewable energy-related projects within waters surrounding the main islands. These projects have the potential to negatively affect seabirds through interactions with wind-turbine structures, lighted facilities, elevated power lines on land, and lighted ships offshore. The USGS is continuing over-land and at-sea tracking studies of seabirds in this area to provide information to assess potential risks posed by proposed offshore energy developments and energy infrastructure. Information collected includes intra- and inter-seasonal and inter-colony differences in foraging behaviors, variability in at-sea habitat use, and ranging behaviors among seabird species including two species listed under the ESA, the Hawaiian petrel and Newell's shearwater.

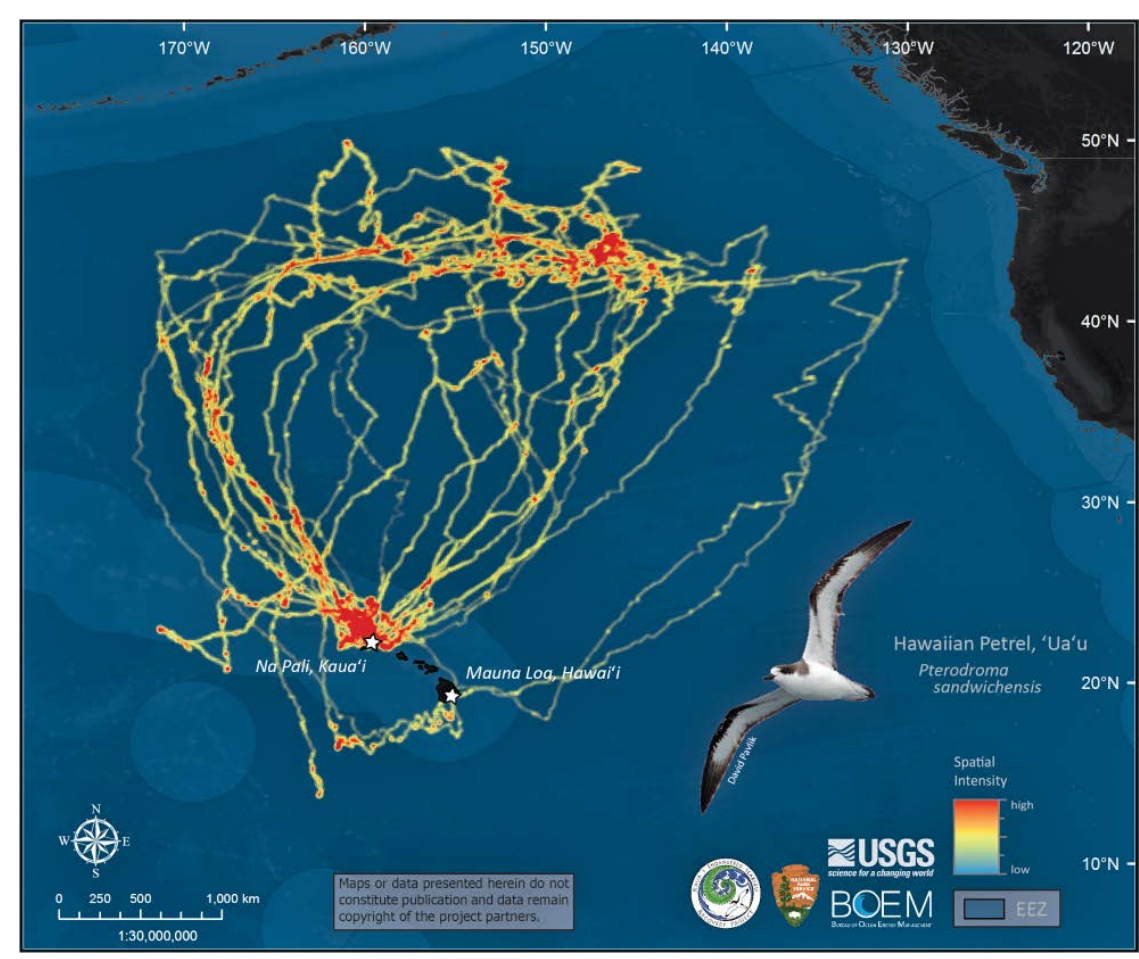

Hawaiian petrel at-sea movements from several breeding colonies in Hawai'i (from USGS, https://www.werc.usgs.gov/ProjectSubWebPage.aspx?SubWebPageID= 3\&Project|D=254).
Josh Adams, USGS Western Ecological Research Center, josh_adams@usgs.gov, (831) 460-7566 


\section{Gulf of Mexico}

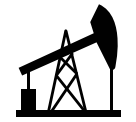

\section{Spatial and Reproductive Ecology of Brown Pelicans in the Gulf of Mexico}

Although the Gulf of Mexico contains a high density of oil infrastructure as well as a rich assemblage of seabirds, baseline data on at-sea distribution and habitat use of these species are poorly understood. Given its distribution patterns, behavior, and known sensitivity to chemical and oil contaminants exposure, the brown pelican is a focal species for investigations of risk exposure in the marine environment. The USGS is leading a study focusing on colony-specific movement patterns, habitat use at sea, and reproductive parameters for brown pelicans across the northern Gulf from Corpus Christi Bay to the Florida Panhandle. USGS scientists deployed GPS satellite tags on 85 adult pelicans breeding in the region to assess spatial ecology. Data were also collected on colony diet, behavior, and reproduction. Data may be used by the USFWS, BOEM, State agencies, and the Gulf Avian Monitoring Network to develop management plans and future research and monitoring efforts.

\section{Contact}

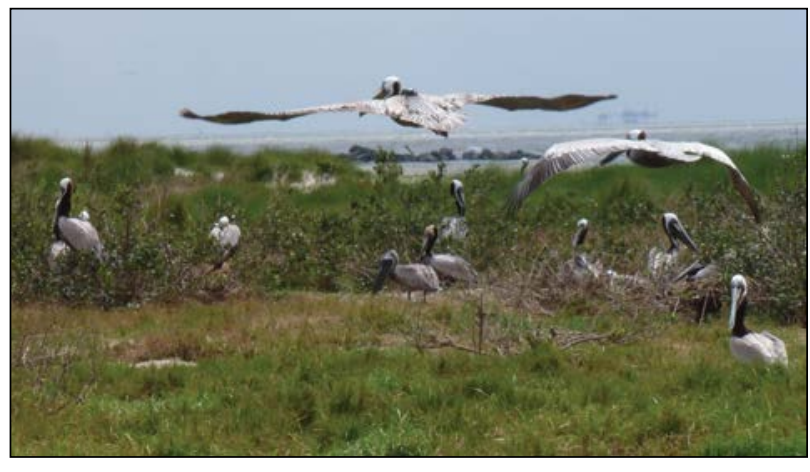

Brown pelican at breeding colony, Raccoon Island, Louisiana.

Patrick Jodice, USGS South Carolina Cooperative Fish and Wildlife Research Unit, pjodice@clemson.edu, (864) 656-6190

\section{Great Lakes}

\section{Monitoring and Mapping Avian Resources in Nearshore and Open Waters of Lake Michigan}

USGS scientists have surveyed pelagic bird use in priority areas of Lake Michigan during fall and winter periods over a 4-year period to determine distribution patterns and abundance in nearshore and open water areas for the common loon, redthroated loon, white-winged scoter, black scoter, surf scoter, long-tailed duck, common merganser, red-breasted merganser, rednecked grebe, horned grebe, greater scaup, lesser scaup, and other waterbirds. Efforts are now focused on developing spatially explicit distribution models of selected waterbirds on Lake Michigan from aerial survey data.

\section{Contact}

Kevin Kenow, USGS Upper Midwest Environmental Sciences Center, kkenow@usgs.gov, (608) 781-6278

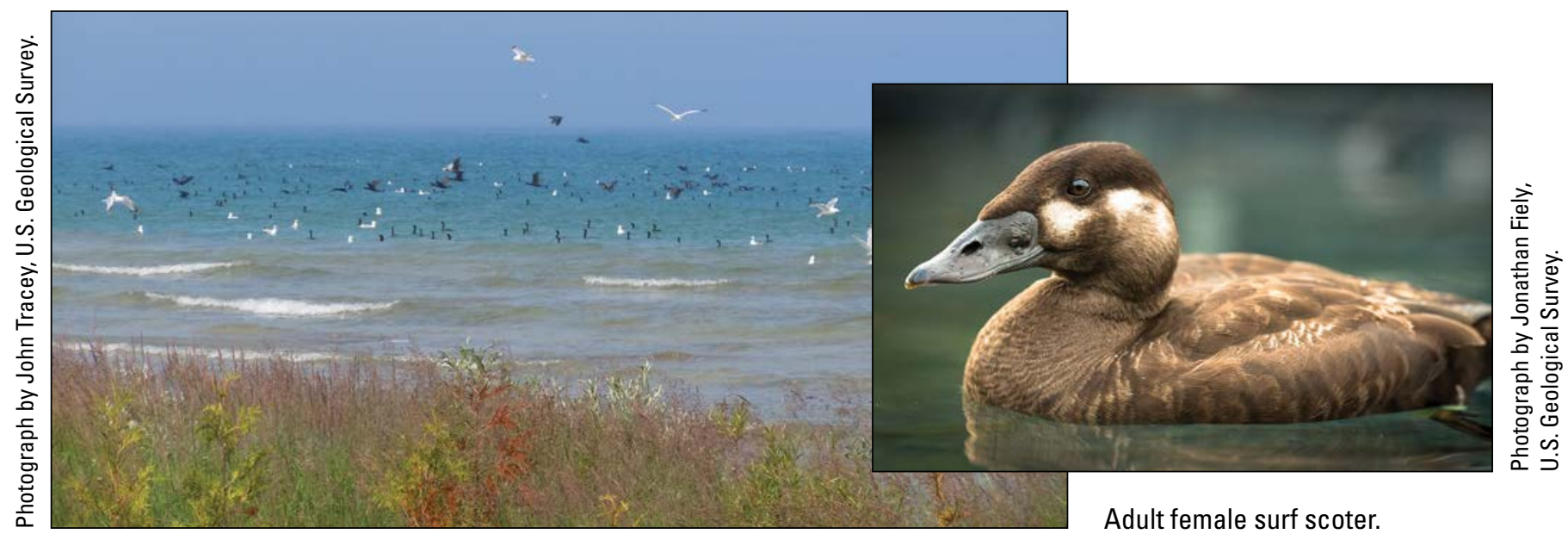

Birds on the shore of Lake Michigan. 
41. Documenting Movements, Habitat Use, and Foraging Patterns of Common Loons and Long-Tailed Ducks

USGS scientists are employing both satellite telemetry and archival geolocator tags to document the movements, habitat use, and foraging patterns of common loons across the Great Lakes during migration relative to future wind energy development. Additional work is underway to radiomark longtailed ducks to determine local movement patterns while wintering on Lake Michigan. Data on waterbird seasonal movement patterns and core use areas based on aerial surveys and telemetry will be used to inform an environmental impact assessment of potential wind turbine placement and assist with identifying, evaluating, and suggesting alternative wind facility sites in the Great Lakes.

\section{Contact}

Kevin Kenow, USGS Upper Midwest Environmental Sciences Center, kkenow@usgs.gov, (608) 781-6278

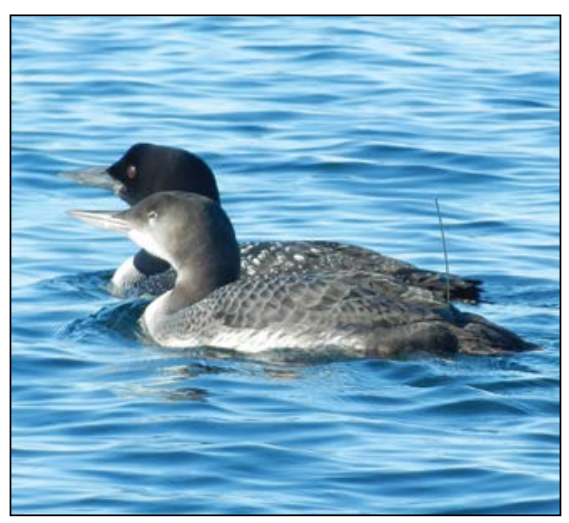

A juvenile common loon wearing a satellite transmitter antenna follows an adult at Tomahawk Lake, Wisconsin.

\section{Airspace Use by Migrating Landbirds at Lake Erie}

Interest is growing to develop wind energy capacity along Great Lakes shorelines both onshore and offshore. With this growth comes the consideration of potential impacts to the large concentrations of landbirds that use the southern Lake Erie shoreline during spring and fall migration. The USGS is using two marine radars operated simultaneously at shoreline and inland sites at 5 or 24 kilometers ( 3 or 15 miles). The data can be used to describe movement patterns of night-migrating landbirds, estimate ascent and descent flight profiles for night-migrating landbirds in relation to distance from the southwestern Lake Erie shoreline, and estimate intensity of nightly bird movements using radar and relate the results to data on banded birds.

\section{Contact}

Eileen Kirsch, USGS Upper Midwest Environmental Sciences Center, ekirsch@usgs.gov, (608) 781-6226

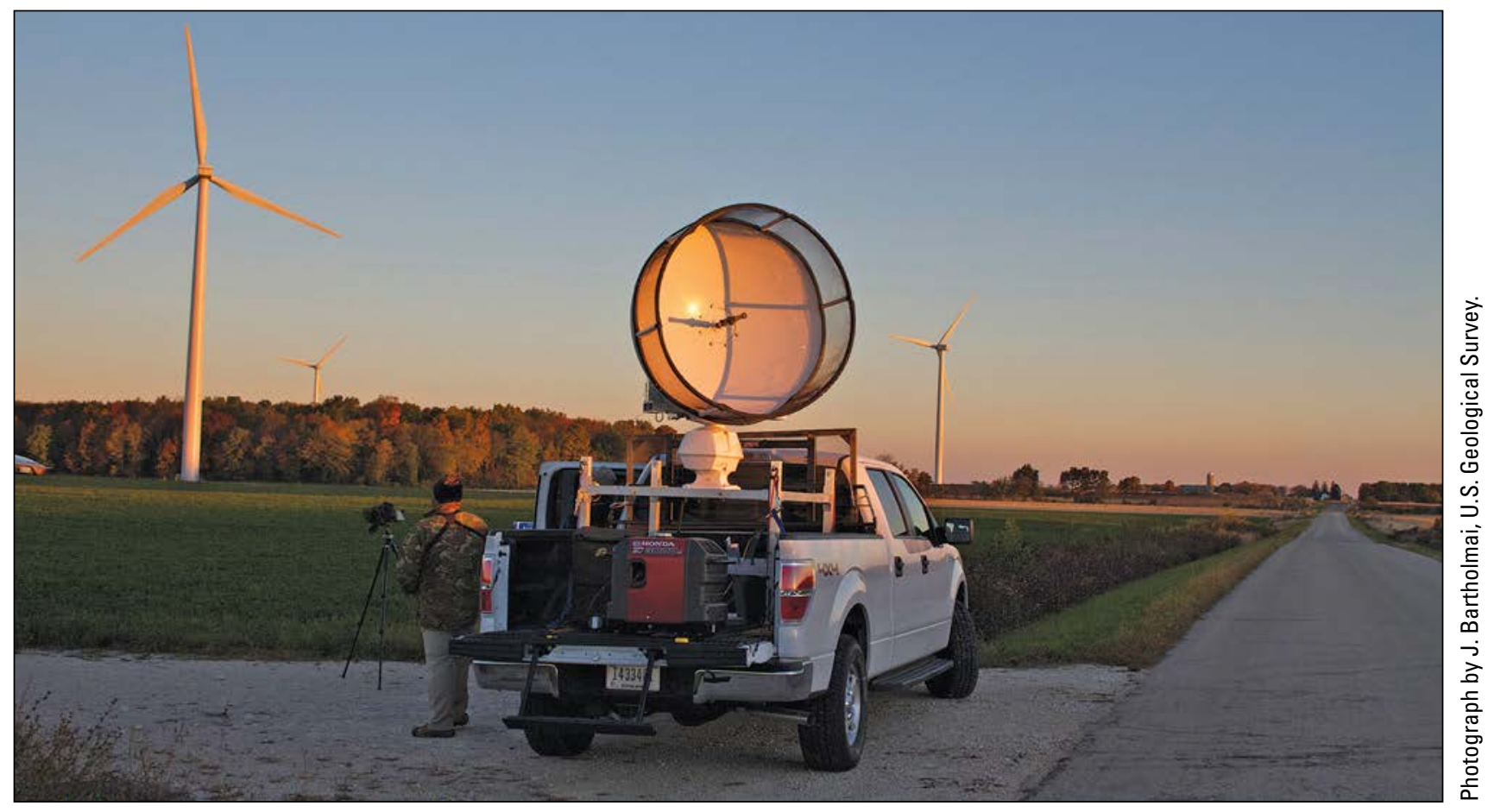

Radar is used to detect the movement patterns and other behaviors of flying animals at night and at distances far beyond the limits of human vision. 


\section{Grassland Birds and Waterbirds}

\section{Waterfowl in Alaska}

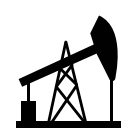

43. Habitat Use of Molting Geese in the National Petroleum Reserve-Alaska

Numerous greater white-fronted geese molt within the National Petroleum ReserveAlaska, and proposed development in this area raises questions about possible impacts to molting geese and their habitats. The USGS used GPS transmitters to record fine-scale location data of white-fronted geese to assess patterns of movement and resource selection relative to vegetation class, year, and body mass at the time of capture. Results demonstrate that flightless white-fronted geese maintain fairly small home ranges across a gradient of habitats, suggesting that suitable habitat for this species is widely distributed. The only constraint documented was the apparent need to molt

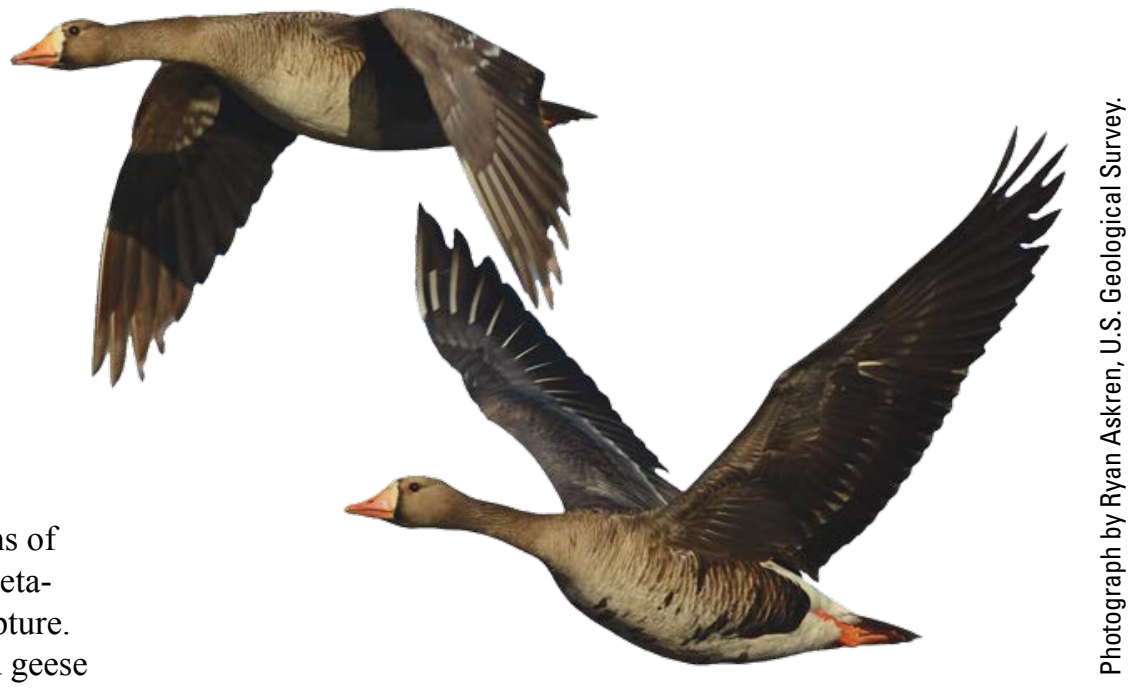

Greater white-fronted geese flying near Chipp South field camp area, North Slope, Alaska. within 100 meters ( 328 feet) of a wetland, a potential escape habitat. Given the apparent widespread availability of suitable habitat in the National Petroleum Reserve-Alaska together with the total potential area available to molting geese, the effect of a limited number of localized displacements resulting from disturbance/ development would not likely be measurable at the population level.

\section{Contact}

John Pearce, USGS Alaska Science Center, jpearce@usgs.gov, (907) 786-7094

\section{Effects of Industrial and Investigator Disturbance on Arctic-Nesting Geese}

Oil and gas development on the Arctic Coastal Plain of Alaska may have effects on Arctic-nesting birds. The USGS used digital cameras and periodic nest visits during 2013-14 to monitor nests of greater white-fronted geese at a disturbed site adjacent to manmade infrastructure and industrial cleanup activities, and a control site more than 2 kilometers (1.2 miles) from sources of industrial disturbance. Using nest photographs, scientists assessed variation in estimates of incubation constancy, nest survival, and predator behavior relative to site, year, and distance from industrial activity. Indirect vehicular and aircraft disturbance posed less risk to nest survival than direct encroachment by observers at nest sites. Therefore, USGS studies suggest that effects of industrial activities on avian productivity in the Arctic may be minimized through practices that limit direct encounters with nests.

\section{Contact}

John Pearce, USGS Alaska Science Center, jpearce@usgs.gov, (907) 786-7094

\section{Publication}

Meixell, B.M., and Flint, P.L., 2017, Effects of industrial and investigator disturbance on Arctic-nesting geese: Journal of Wildlife Management, prepublication early view, https://doi.org/10.1002/jwmg.21312. 


\section{Quantifying Shifts in Waterfowl and Their Habitat in the National Petroleum} Reserve-Alaska

The Arctic Coastal Plain of northern Alaska has experienced a warming trend over the past 30 years, leading to reductions in sea ice and saltwater inundation of coastal habitats. Saltwater tolerant plants are now thriving in these areas. Since the 1970s, data collected by the USFWS have indicated a shift in the distribution of molting black brant geese in the Teshekpuk Lake Special Area. The USGS determined that black brant geese are using new molting areas on the coast, away from traditionally used large inland lakes. This shift in distribution is due to an increase in high-quality forage along the coast brought about by reduced sea ice. The USGS is developing forecasts of future habitat quality for geese that can assist management planning for potential development scenarios.

\section{Contact}

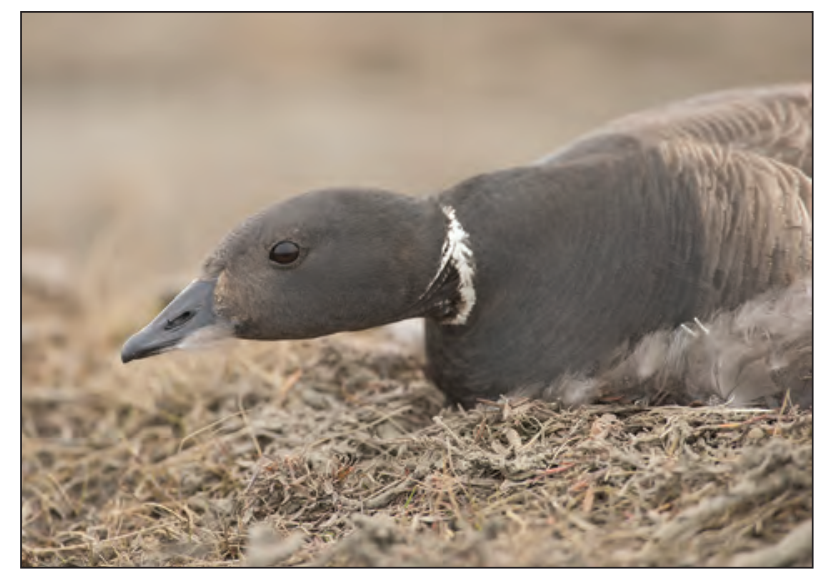

A black brant goose on its nest, Colville field camp area, North Slope, Alaska.

John Pearce, USGS Alaska Science Center, jpearce@usgs.gov, (907) 786-7094

\section{Publication}

Flint, Paul, Whalen, Mary, and Pearce, John, 2014, Changing arctic ecosystems-Sea ice decline, permafrost thaw, and benefits for geese: U.S. Geological Survey Fact Sheet 2014-3088, 2 p., https://doi.org/10.3133/fs20143088.

\section{Grassland Birds in Northern Prairie and Great Plains}

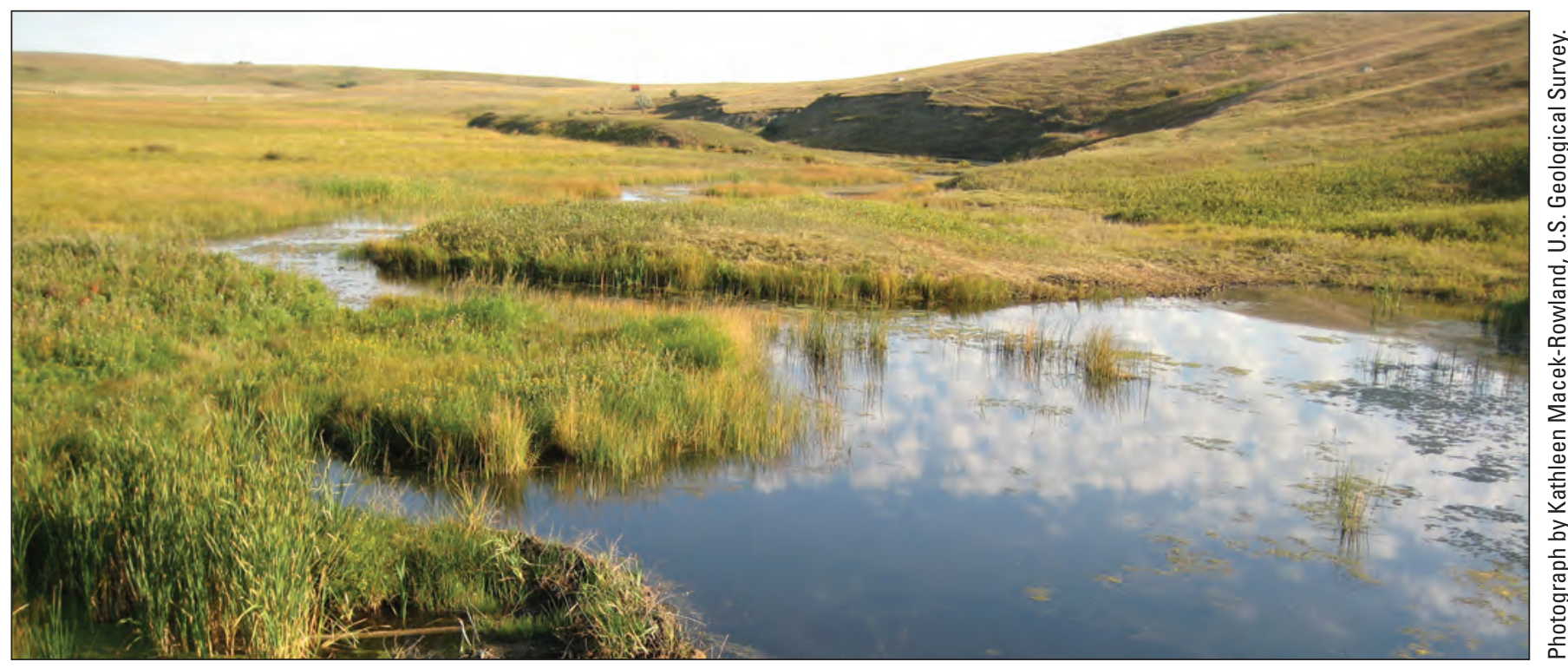

A meandering stream in North Dakota.

\section{A Mitigation Tool for Estimating the Impact of Wind Energy Development on Grassland Birds in the Northern Great Plains}

USGS scientists used results from a 10-year field study of the influence of wind facilities on breeding grassland birds to develop a tool to help wildlife agencies, conservation groups, and wind developers determine conservation measures that mitigate habitat lost to energy development. The study consisted of a before-after-control-impact assessment on three wind facilities in North and South Dakota and examined displacement or attraction one year after construction and the average displacement 
or attraction 2-5 years after construction; scientists also tested for these effects overall as a function of distance from turbines for nine species. Using these results, the USGS developed a method for computing the displacement rate for grassland bird pairs and the amount of grassland needed to support these displaced pairs. Either the displacement rate or the grassland acreage can be applied to mitigation scenarios in situations where developers want to provide compensation for impacts.

\section{Contact}

Jill Shaffer, USGS Northern Prairie Wildlife Research Center, jshaffer@usgs.gov, (701) 253-5547

\section{Publication}

Shaffer, J.A., and Buhl, D.A., 2016, Effects of wind-energy facilities on grassland bird distributions: Conservation Biology, v. 30, no. 1, p. 59-71, https://doi.org/10.1111/cobi.12569.

\section{Birds and the Bakken Formation: Integration of Oil Well, Land Cover, and Species Distribution Data to Inform Conservation}

The USGS is leading a project to measure the effects of well development on birds in the Williston Basin in eastern Montana, western North Dakota, and South Dakota. Scientists plan to create maps that combine data on habitat conversion and species distribution to describe the effects of disturbance from oil well pads on biodiversity. Models are also being developed to display past and potential future effects of energy development on grassland birds. This information may assist managers with prioritizing areas for conservation in the Williston Basin.

\section{Contact}

Todd Preston, USGS Northern Rocky Mountain Science Center, tmpreston@usgs.gov, (406) 994-5034

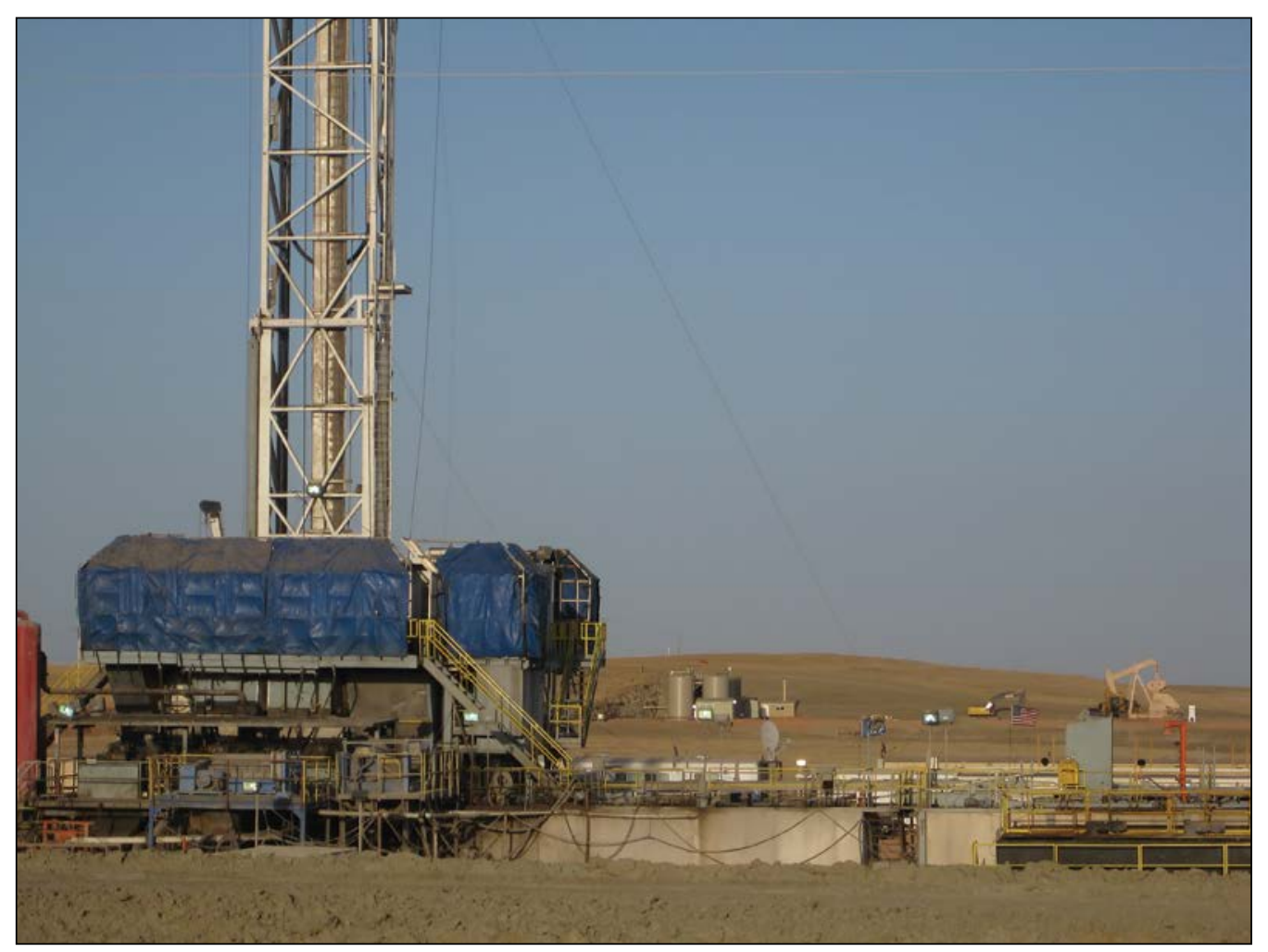

A drill rig in the Bakken oil field in Stark County, western North Dakota. 


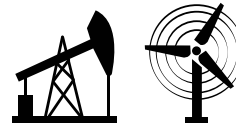
48. Lesser Prairie-Chicken Population and Habitat Ecology

(esser prairie-chicken currently occupies a range that includes portions of Colorado, Kansas, New Mexico, Oklahoma, and Texas. This species has experienced population declines due to both direct and indirect habitat loss, including conversion of native rangeland to cropland and disturbance from energy development. The USGS developed a population viability analysis (PVA) model to predict future population status of the lesser prairie-chicken in four ecoregions across the species' range. Studies by the USGS and collaborators predict habitat suitability for lesser-prairie-chicken leks by exploring lesser prairie-chicken occurrence in relation to landscape characteristics, drought, and anthropogenic effects, such as distance to active wells, roads, highways, transmission lines, and tall structures. Habitat suitability models, combined with other landscape information, form the basis of a habitat assessment tool that can be used to guide siting of development projects and targeting of areas for conservation.

\section{Contacts}

Clint Boal, USGS Texas Cooperative Fish and Wildlife Research Unit, cboal@usgs.gov, (806) 742-2851

Dave Haukos, USGS Kansas Cooperative Fish and Wildlife Research Unit, dhaukos@ksu.edu, (785) 532-5761

\section{Publications}

Fritts, S.R., Grisham, B.A., Cox, R.D., Boal, C.W., Hagen, C.A., Haukos, D.A., McDaniel, Patricia, and Erickson, A.N., in press, Influence of vegetation structure and composition on lesser prairie-chicken demographics following an intense drought: Rangeland Ecology and Management.

Cummings, J.W., Converse, S.J., Moore, C.T., Smith, D.R., Nichols, C.T., Allan, N.L., and O’Meilia, C.M., 2017, A projection of lesser prairie-chicken (Tympanuchus pallidicinctus) populations range-wide: U.S. Geological Survey Open-File Report 2017-1071, https://doi.org/10.3133/ofr20171071.

Lautenbach, J.M., Plumb, R.T., Robinson, S.G., Hagen, C.A., Haukos, D.A., and Pitman, J.C., 2017, Lesser prairiechicken avoidance of trees in a grassland landscape: Rangeland Ecology and Management, v. 70, no. 1, p. 78-86, https://doi.org/10.1016/j.rama.2016.07.008.

Spencer, David, Haukos, David, Hagen, Christian, Daniels, Melinda, and Goodin, Doug, 2017, Conservation Reserve Program mitigates grassland loss in the lesser prairie-chicken range of Kansas: Global Ecology and Conservation, v. 9, p. 21-38, https://doi.org/10.1016/j.gecco.2016.11.004.

Earl, J.E., Fuhlendorf, S.D., Haukos, David, Tanner, A.M., Elmore, Dwayne, and Carleton., S.A., 2016, Characteristics of lesser prairie-chicken (Tympanuchus pallidicinctus) long-distance movements across their distribution: Ecosphere, v. 7, no. 8, e01441, https://doi.org/10.1002/ecs2.1441.

Fritts, S.F., Grisham, B.A., Haukos, D.A., Boal, C.W., Patten, M.A., Wolfe, D.H., Dixon, C.E., Cox, R.D., and Heck., W.R., 2016, Long-term lesser prairie-chicken nest ecology in response to grassland management: Journal of Wildlife Management, v. 80, p. 527-539, https://doi.org/10.1002/jwmg.1042.

Grisham, B.A., Godar, A.J., Boal, C.W., and Haukos, D.A., 2016, Interactive effects between nest microclimate and nest vegetation structure confirm microclimate thresholds for lesser prairie-chicken nest survival: The Condor, v. 118, no. 4, p. 728-746, https://doi.org/10.1650/CONDOR-16-38.1.

Haukos, D.A., and Boal, C.W., eds., 2016, Ecology and conservation of lesser prairie-chickens: Boca Raton, Fla., CRC Press, v. $48,371 \mathrm{p}$.

Jarnevich, C.S., Holcombe, T.R., Grisham, B.A., Timmer, Jennifer, Boal, C.W., Butler, M.J., Pitman, James, Kyle, S.C., Klute, David, Beauprez, G.M., Janus, Allan, and Van Pelt, W.E., 2016, Assessing range-wide habitat suitability for the lesser prairiechicken: Avian Conservation and Ecology, v. 11, no. 1, unpaginated, https://doi.org/10.5751/ace-00807-110102. [Title and abstract also in French] 
Robinson, S.G., Haukos, D.A., Plumb, R.T., Hagen, C.A., Pitman, J.C., Lautenbach, J.M., Sullins, D.S., Kraft, J.D., and Lautenbach, J.D., 2016, Lesser prairie-chicken fence collision risk across its northern distribution: Journal of Wildlife Management, v. 80, no. 5, p. 906-915, https://doi.org/10.1002/jwmg.1073.

Zavaleta, J.C., Haukos, D.A., Grisham, Blake, Boal, Clint, and Dixon, Charles, 2016, Restoring sand shinnery oak prairies with herbicide and grazing in New Mexico: Southwestern Naturalist, v. 61, no. 3, p. 225-232, https://doi.org/10.1894/0038-4909-61.3.225.

Winder, V.L., Carrlson, K.M., Gregory, A.J., Hagen, C.A., Haukos, D.A., Kesler, D.C., Larsson, L.C., Matthews, T.W., McNew, L.B., Patten, M.A., Pitman, J.C., Powell, L.A., Smith, J.A., Tom Thompson, Wolfe, D.H., and Sandercock, B.K., 2015, Factors affecting female space use in ten populations of prairie chickens: Ecosphere, v. 6, no. 9, p. 1-17, https://doi.org/10.1890/ES14-00536.1.

Grisham, B.A., Borsdorf, P.K., Boal, C.W., and Boydston, K.K., 2014, Nesting ecology and nest survival of lesser prairie-chickens on the southern High Plains of Texas: Journal of Wildlife Management, v. 78, no. 5, p. 857-866, https://doi.org/10.1002/jwmg.716.

Timmer, J.M., Butler, M.J., Ballard, W.B., Boal, C.W., and Whitlaw, H.A., 2013, Abundance and density of lesser prairiechickens and leks in Texas: Wildlife Society Bulletin, v. 37, no. 4, p. 741-749, https://doi.org/10.1002/wsb.304.

Jarnevich, C.S., and Laubhan, M.K., 2011, Balancing energy development and conservation-A method utilizing species distribution models: Environmental Management, v. 47, no. 5, p. 926-936, https://doi.org/10.1007/s00267-011-9651-2.

\section{Birds in the Intermountain West}

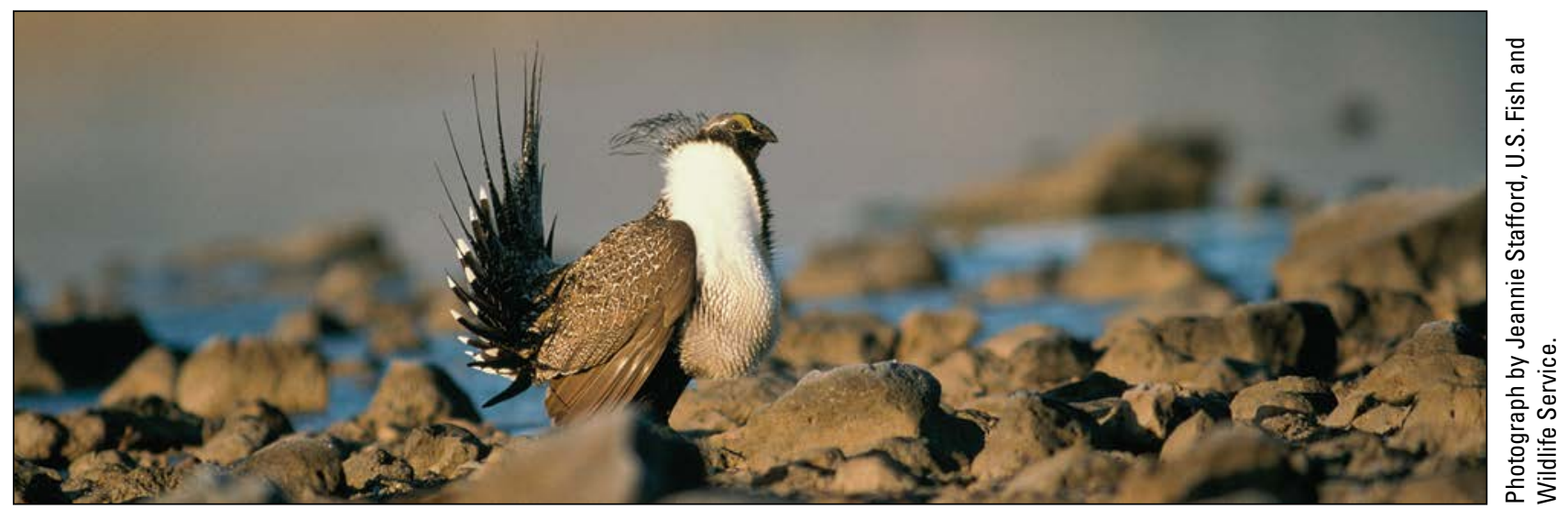

Greater sage-grouse.

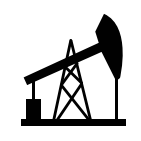

\section{Impacts of Oil and Gas Development on Greater Sage-Grouse Lek Attendance}

The greater sage-grouse has experienced population declines over several decades attributable to a variety of disturbances, including oil and gas development. To better understand how male sage-grouse lek attendance is affected by oil and gas development, the USGS and Colorado State University analyzed changes in counts of male sage-grouse at leks in Wyoming from 1984 to 2008. The results showed that male sage-grouse lek attendance declined by approximately 2.5 percent per year. Increasing density of oil and gas wells was correlated with decreasing lek attendance. The effects of oil and gas development on lek attendance were observed up to 6 kilometers (4 miles) from leks, and attendance lagged for 4 years following development. Lek attendance was stable when no wells were present near a lek and began declining with the addition of the first well. This science can further assist resource managers in the active management of sagebrush habitats.

\section{Contact}

Cameron Aldridge, USGS Fort Collins Science Center, aldridgec@usgs.gov, (970) 226-9433

\section{Publication}

Green, A.W., Aldridge, C.L., and O'Donnell, M.S., 2017, Investigating impacts of oil and gas development on greater sagegrouse: Journal of Wildlife Management, v. 81, no. 1, p. 46-57, https://doi.org/10.1002/jwmg.21179. 


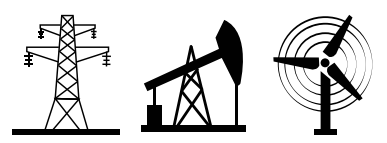

\section{Effects of Energy Development on Greater Sage-Grouse and Their Predators}

An increasing human footprint across ecosystems in the American West often results in disturbances to native vegetation and related changes that are favorable to generalist predator species. A large portion of the Great Basin consists of proposed and recently developed energy transmission lines and renewable energy sources (such as geothermal energy and wind). Further development could continue to fragment the contiguous sagebrush-steppe ecosystems that provide seasonal habitat for greater sage-grouse populations. The USGS, in collaboration with other Federal and State agencies and private industry, is working to understand how energy development and habitat loss influence predator-prey interactions between ravens and nesting sage-grouse. This science provides resource managers with information and tools to help develop guidelines for future energy-related projects to minimize adverse impacts on sage-grouse populations.

\section{Contacts}

Michael Casazza, USGS Western Ecological Research Center, mike_casazza@usgs.gov, (530) 669-5075

Peter Coates, USGS Western Ecological Research Center, pcoates@usgs.gov, (530) 669-5073

\section{Publications}

Coates, P.S., Casazza, M.L., Ricca, M.A., Brussee, B.E., Blomberg, E.J., Gustafson, K.B., Overton, C.T., Davis, D.M., Niell, L.E., Espinosa, S.P., Gardner, S.C., and Delehanty, D.J., 2015, Integrating spatially explicit indices of abundance and habitat

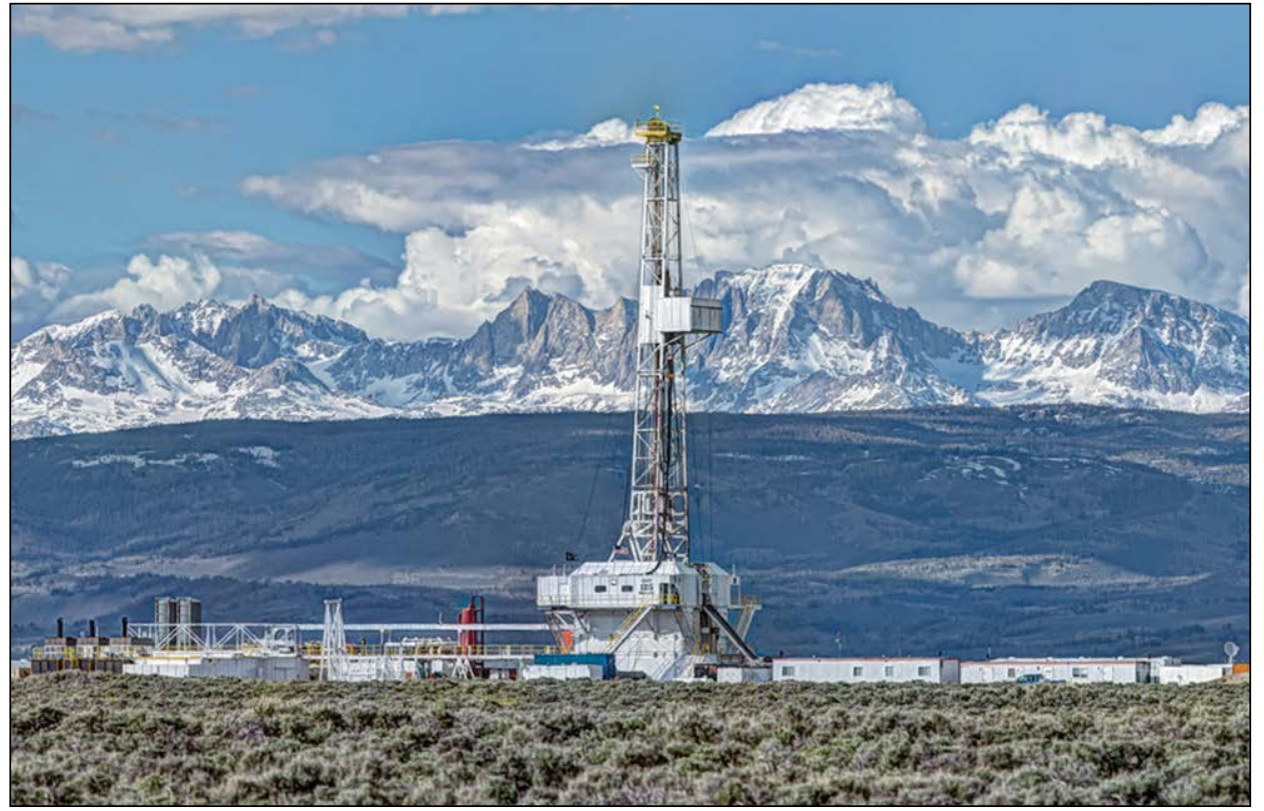

Oil and gas exploration in the Intermountain West. quality_An applied example for greater sage-grouse management: Journal of Applied Ecology, v. 53, no. 1, p. 83-95, https://doi.org/10.1111/1365-2664.12558.

Howe, K.B., and Coates, P.S., 2015, Observations of territorial breeding common ravens caching eggs of greater sage-grouse: Journal of Fish and Wildlife Management, v. 6, no. 1, p. 187-190, https://doi.org/10.3996/042014-jfwm-030.

Coates, P.S., Casazza, M.L., Brussee, B.E., Ricca, M.A., Gustafson, K.B., Overton, C.T., Sanchez-Chopitea, Erika, Kroger, Travis, Mauch, Kimberly, Niell, Lara, Howe, Kristy, Gardner, Scott, Espinosa, Shawn, and Delehanty, D.J., 2014, Spatially explicit modeling of greater sage-grouse (Centrocercus urophasianus) habitat in Nevada and northeastern California-A decision-support tool for management: U.S. Geological Survey Open-File Report 2014-1163, https://doi.org/10.3133/ ofr20141163.

Coates, P.S., Howe, K.B., Casazza, M.L., and Delehanty, D.J., 2014, Common raven occurrence in relation to energy transmission line corridors transiting human-altered sagebrush steppe: Journal of Arid Environments, v. 111, p. 68-78, https://doi.org/10.1016/j.jaridenv.2014.08.004.

Coates, P.S., Howe, K.B., Casazza, M.L., and Delehanty, D.J., 2014, Landscape alterations influence habitat use of nesting buteos and ravens within sagebrush ecosystems-Implications for transmission line development: The Condor, v. 116, no. 3, p. 341-356, https://doi.org/10.1650/condor-13-126.1.

Howe, K.B., Coates, P.S., and Delehanty, D.J., 2014, Selection of anthropogenic features and vegetation characteristics by nesting common ravens in the sagebrush ecosystem: The Condor, v. 116, no. 1, p. 35-49, https://doi.org/10.1650/ condor-13-115-r2.1. 


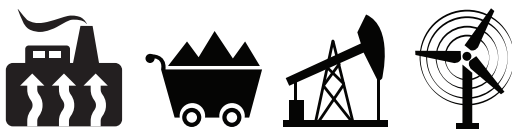

\section{Implications of Anthropogenic Activities on Greater Sage-Grouse Populations in Nevada}

The USGS has initiated a study at nine sites across Nevada to answer questions related to long-term and short-term effects of disturbance caused by wind turbines, gold mining, geothermal energy production, hydraulic fracturing for oil, and transmission line development on sage-grouse habitat selection, population vital rates, and movement patterns. This information can help managers develop guidelines that strive to minimize the negative effects of these activities on greater sage-grouse and their associated habitat.

\section{Contact}

Peter Coates, USGS Western Ecological Research Center, pcoates@usgs.gov, (530) 669-5073

\section{Breeding Sagebrush Songbird Responses to Gas Development: Patterns and Mechanisms}

USGS research since 2008 in two natural gas fields, Pinedale Anticline and the Jonah Field, in western Wyoming has documented patterns in the abundance and nesting success of three sagebrush-obligate passerine birds-Brewer's sparrow, sagebrush sparrow, and sage thrasher - the populations of which are declining in many parts of their range. Abundance of the two sparrows decreased with increased density of natural gas wells, and all three songbird species experienced lower nest survival in areas with greater surrounding habitat loss due to natural gas infrastructure. The primary cause of nest failures in the study area is nest predation by rodents, which increased in abundance with natural gas development. The increased rodent abundance was not caused by a decrease in mesopredators. Current work is focused on the potential effects of altered herbaceous communities associated with reclaimed areas on rodent abundance, and the joint effects of climate variability and physical habitat loss due to energy development on songbird productivity.

\section{Contact}

Anna D. Chalfoun, USGS Wyoming Cooperative Fish and Wildlife Research Unit, achalfoun@usgs.gov, (307) 766-6966

\section{Publications}

Hethcoat, M.G., and Chalfoun, A.D., 2015, Energy development and avian nest survival in Wyoming, U.S.A.-A test of a common disturbance index: Biological Conservation, v. 184, p. 327-334, https://doi.org/10.1016/j.biocon.2015.02.009.

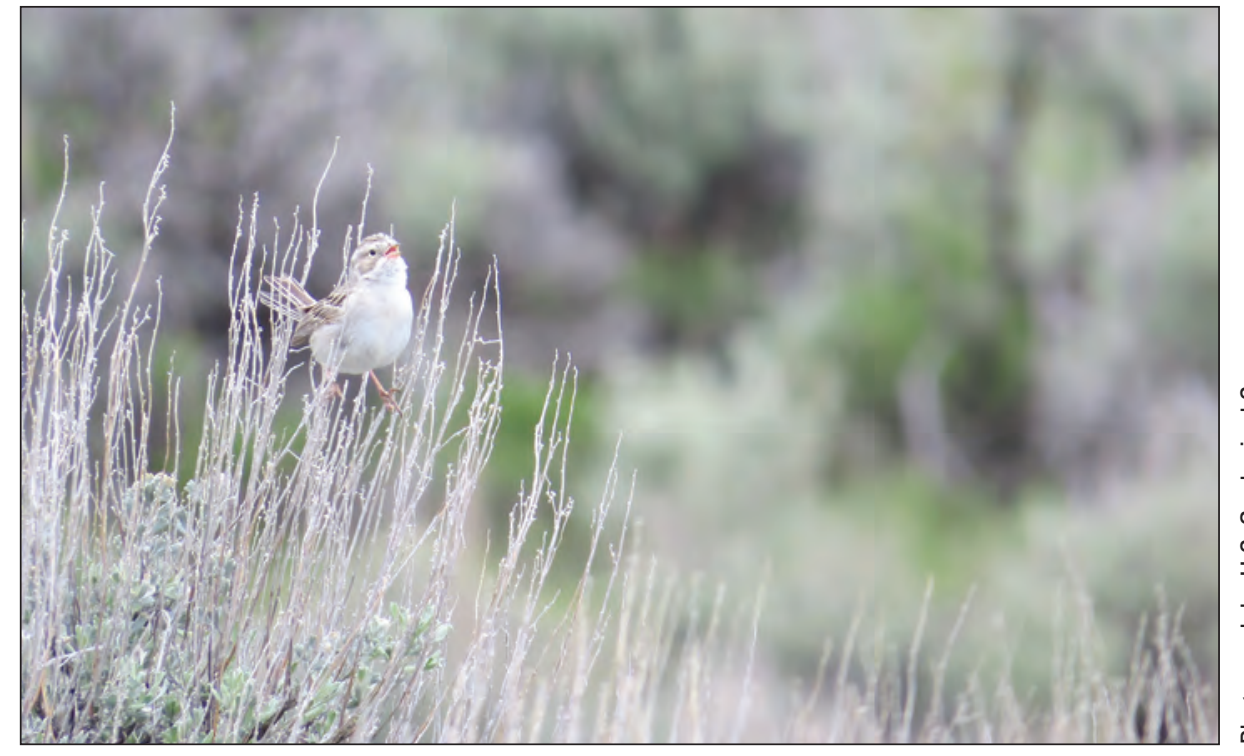

A male Brewer's sparrow singing from his sagebrush perch.
Hethcoat, M.G., and Chalfoun, A.D., 2015, Toward a mechanistic understanding of humaninduced rapid environmental change-A case study linking energy development, avian nest predation, and nest predators: Journal of Applied Ecology, v. 52, no. 6, p. 1492-1499, https://doi.org/10.1111/13652664.12513.

Gilbert, M.M., and Chalfoun, A.D., 2011, Energy development affects populations of sagebrush songbirds in Wyoming: Journal of Wildlife Management, v. 75, no. 4, p. 816-824, https://doi.org/10.1002/ jwmg. 123. 


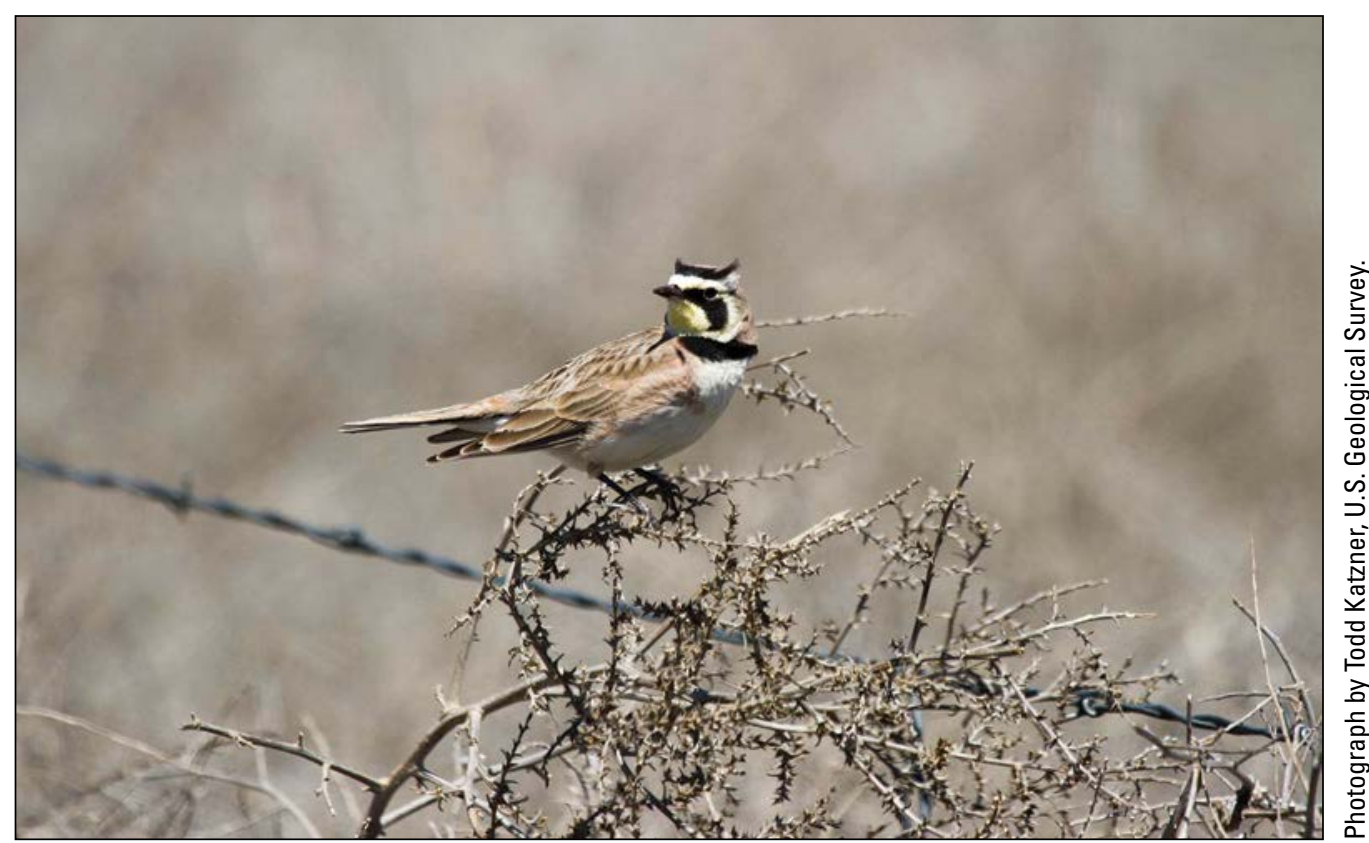

Horned lark.

\section{Additional Publications About Songbirds, Grassland Birds, and Waterbirds}

Farwell, L.S., Wood, P.B., Sheehan, James, and George, G.A., 2016, Shale gas development effects on the songbird community in a central Appalachian forest: Biological Conservation, v. 201, p. 78-91, https://doi.org/10.1016/j.biocon.2016.06.019.

Graff, B.J., Jenks, J.A., Stafford, J.D., Jensen, K.C., and Grovenburg, T.W., 2016, Assessing spring direct mortality to avifauna from wind energy facilities in the Dakotas: Journal of Wildlife Management, v. 80, no. 4, p. 736-745, https://doi.org/10.1002/ jwmg.1051.

Mahoney, Anika, and Chalfoun, A.D., 2016, Reproductive success of horned lark and McCown's longspur in relation to wind energy infrastructure: The Condor, v. 118, no. 2, p. 360-375, https://doi.org/10.1650/condor-15-25.1.

Pearse, A.T., Brandt, D.A., and Krapu, G.L., 2016, Wintering sandhill crane exposure to wind energy development in the central and southern Great Plains, U.S.A.: The Condor, v. 118, no. 2, p. 391-401, https://doi.org/10.1650/condor-15-99.1.

Kirsch, E.M., Wellik, M.J., Suarez, Manuel, Diehl, R.H., Lutes, Jim, Woyczik, Wendy, Krapfl, Jon, and Sojda, Richard, 2015, Observations of sandhill cranes' (Grus canadensis) flight behavior in heavy fog: The Wilson Journal of Ornithology, v. 127, no. 2, p. 281-288, https://doi.org/10.1676/wils-127-02-281-288.1.

Pearse, A.T., Brandt, D.A., Harrell, W.C., Metzger, K.L., Baasch, D.M., and Hefley, T.J., 2015, Whooping crane stopover site use intensity within the Great Plains: U.S. Geological Survey Open-File Report 2015-1166, https://doi.org/10.3133/ ofr20151166.

Thompson, S.J., Johnson, D.H., Nieumuth, N.D., and Ribic, C.A., 2015, Avoidance of unconventional oil wells and roads exacerbates habitat loss for grassland birds in the North American Great Plains: Biological Conservation, v. 192, p. 82-90, https://doi.org/10.1016/j.biocon.2015.08.040.

Wood, P.B., and Ammer, F.K., 2015, Grasshopper sparrow reproductive success and habitat use on reclaimed surface mines varies by age of reclamation: Wildlife Society Bulletin, v. 39, no. 3, p. 512-520, https://doi.org/10.1002/wsb.563.

Buler, J.J., and Dawson, D.K., 2014, Radar analysis of fall bird migration stopover sites in the Northeastern U.S.: The Condor, v. 116, no. 3, p. 357-370, https://doi.org/10.1650/condor-13-162.1.

Manier, D.J., Bowen, Z.H., Brooks, M.L., Casazza, M.L., Coates, P.S., Deibert, P.A., Hanser, S.E., and Johnson, D.H., 2014, Conservation buffer distance estimates for greater sage-grouse-A review: U.S. Geological Survey Open-File Report 2014-1239, https://doi.org/10.3133/ofr20141239.

Uden, D.R., Allen, C.R., Mitchell, R.B., McCoy, T.D., and Guan, Qingfeng, 2014, Predicted avian responses to bioenergy development scenarios in an intensive agricultural landscape: GCB Bioenergy, v. 7, no. 4, p. 717-726, https://doi.org/10.1111/ gcbb.12157. 


\section{Alaska Marine and Avian Species}

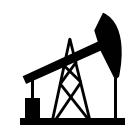

\section{North Pacific Pelagic Seabird Survey Data}

The USGS produced the North Pacific Pelagic Seabird Database, an online resource compiling the results of 40 years of surveys by biologists from the United States, Canada, Japan, and Russia. The database documents the abundance and distribution of 160 seabird and 41 marine mammal species over a 26-million-square-kilometer (10-million-square-mile) region of the North Pacific. This database offers a powerful tool for analysis and mitigation of anthropogenic effects on marine ecosystems of the Arctic and North Pacific, including the impacts of oil development and production, fisheries, and vessel traffic. It also creates an unprecedented opportunity to study the biogeography and marine ecology of dozens of species of seabirds and marine mammals throughout their range in Continental Shelf waters of the United States.

\section{Contacts}

Gary Drew, USGS Alaska Science Center, gdrew@usgs.gov, (907) 786-7168

John Piatt, USGS Alaska Science Center, jpiatt@usgs.gov, (360) 774-0516

\section{Publications}

Renner, Martin, Salo, Sigrid, Eisner, L.B., Ressler, P.H., Ladd, Carol, Kuletz, K.J., Santora, J.A., Piatt, J.F., Drew, G.S., and Hunt, G.L., 2016, Timing of ice retreat alters seabird abundances and distributions in the southeast Bering Sea: Biological Letters, v. 12, no. 9, e20160276, https://doi.org/10.1098/rsbl.2016.0276.

Drew, G.S., Piatt, J.F., and Renner, M., 2015, User's guide to the North Pacific Pelagic Seabird Database 2.0: U.S. Geological Survey Open-File Report 2015-1123, 52 p., https://doi.org/10.3133/ofr20151123.

\section{Status of Seabirds and Forage Fish in Cook Inlet, Alaska}

Seabird densities in lower Cook Inlet are among the highest in Alaska, which is why seabird populations were decimated by the Exxon Valdez oil spill in 1989. Large resident and migratory seabird populations are sustained by locally abundant stocks of key forage fish species. Monitoring of seabird populations and forage fish stocks in potential oil and gas lease areas has been a BOEM priority, both to mitigate the impacts of development and to assess the impact of potential oil spills. Following intensive investigations of seabirds and forage fish in lower Cook Inlet during 1995-2000, the USGS initiated new studies in 2016 to update our knowledge in advance of potential lease sales and associated activities in Cook Inlet during 2017 and beyond. Ongoing studies are assessing changes in seabird and fish populations following the anomalous high temperatures in 2014-16.

\section{Contact}

John Piatt, USGS Alaska Science Center, jpiatt@usgs.gov, (360) 774-0516

\section{Gulf Watch Alaska Program for Quantifying Coastal Marine Ecosystem Change}

ID

Oil and gas development and transportation activities are major components of Alaska's economy, and some of that activity occurs along Alaska's coasts. The USGS is engaged in a collaborative marine monitoring program, Gulf Watch Alaska, which documents the status of coastal marine ecosystems, variation over time, and underlying drivers of observed change. This work quantifies abundance, distribution, and temporal variation in hundreds of marine species, including many of high interest to management agencies. This work provides context for understanding potential response of marine ecosystems to energy development relative to other sources of change.

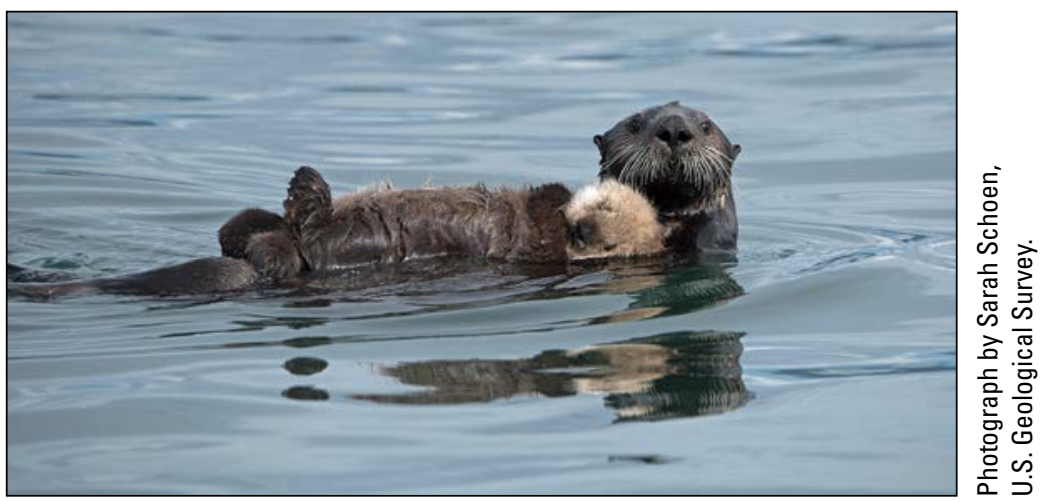

Sea otter with pup in the Gulf of Alaska. 


\section{Contact}

Grant Hilderbrand, USGS Alaska Science Center, ghilderbrand@usgs.gov, (907) 786-7076

\section{Publications}

Bowen, Lizabeth, Miles, A.K., Ballachey, Brenda, Waters, Shannon, Bodkin, James, Lindeberg, Mandy, and Esler, Daniel, in press, Gene transcription patterns in response to low level petroleum contaminants in Mytilus trossulus from field sites and harbors in southcentral Alaska: Deep Sea Research Part II-Topical Studies in Oceanography, corrected proof available online August 18, 2017, https://doi.org/10.1016/j.dsr2.2017.08.007.

Bodkin, J.L., Coletti, H.A., Ballachey, B.E., Monson, D.H., Esler, Daniel, and Dean, T.A., 2017, Variation in abundance of Pacific blue mussel (Mytilus trossulus) in the northern Gulf of Alaska, 2006-2015: Deep Sea Research Part II-Topical Studies in Oceanography, corrected proof available online April 14, 2017, https://doi.org/10.1016/j.dsr2.2017.04.008.

Bowen, Lizabeth, Miles, A.K., Ballachey, Brenda, Waters, Shannon, and Bodkin, James, 2016, Gene transcript profiling in sea otters post-Exxon Valdez oil spill —A tool for marine ecosystem health assessment: Journal of Marine Science and Engineering, v. 4, no. 2, p. 39, https://doi.org/10.3390/jmse4020039.

Coletti, H.A., Bodkin, J.L., Monson, D.H., Ballachey, B.E., and Dean, T.A., 2016, Detecting and inferring cause of change in an Alaska nearshore marine ecosystem: Ecosphere, v. 7, no. 10, e01489, https://doi.org/10.1002/ecs2.1489.

von Biela, V.R., Newsome, S.D., Bodkin, J.L., Kruse, G.H., and Zimmerman, C.E., 2016, Widespread kelpderived carbon in pelagic and benthic nearshore fishes: Estuarine, Coastal and Shelf Science, v. 181, p. 364-374, https://doi.org/10.1016/j.ecss.2016.08.039.

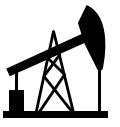

\section{Long-Term Response of Wildlife to the Exxon Valdez Oil Spill in Alaska}

The USGS has been heavily involved in studies documenting the effects and recovery of wildlife population from the 1989 Exxon Valdez oil spill in Alaska, particularly on sea otters and sea ducks. This work has resulted in a paradigm shift when considering the consequences of catastrophic oil spills, including appreciation that the effects for some species persisted well beyond the first weeks and months after the spill; for the most vulnerable species, effects were detectable for decades. Also, wildlife populations were affected by the Exxon Valdez spill through many different mechanisms, including the expected direct toxic effects, but also through more subtle, indirect pathways.

\section{Contact}

Grant Hilderbrand, USGS Alaska Science Center, ghilderbrand@usgs.gov, (907) 786-7076

\section{Publications}

Esler, Daniel, Ballachey, B.E., Matkin, C.O., Cushing, Daniel, Kaler, Robert, Bodkin, James, Monson, Daniel, Esslinger, G.G., and Kloecker, Kim, 2017, Timelines and mechanisms of wildlife population recovery following the Exxon Valdez oil spill: Deep Sea Research II- Topical Studies in Oceanography, corrected proof available online April 14, 2017, https://doi.org/10.1016/j.dsr2.2017.04.007.

Esler, Daniel, Ballachey, B.E., Bowen, Lizabeth, Miles, A.K., Dickson, R.D., and Henderson, J.D., 2016, Cessation of oil exposure in harlequin ducks after the Exxon Valdez oil spill—Cytochrome P4501A biomarker evidence: Environmental Toxicology and Chemistry, v. 36, no. 5, p. 1294-1300, https://doi.org/10.1002/etc.3659. 


\section{Marine and Terrestrial Animals}

\section{Understand Risks}

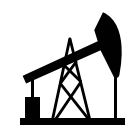

\section{Influence of Energy Development on Mule Deer Migrations}

Migratory ungulates are often exposed to anthropogenic disturbance along their migration corridors. Understanding the influence of development on migratory behavior and phenology tracking (optimal foraging) is critical to successful planning and conservation. USGS scientists have used GPS collar data to evaluate the influence of development on behavior and phenology tracking of mule deer in western Wyoming. They found that deer increased movement rates under intense development conditions and shifted stopover areas away from development, but largely maintained fidelity to individual routes. Phenology tracking - the ability of deer to access the highest quality forage patches in the spring - declined over time in areas with rapidly expanding energy development. These results indicate that development in migration corridors may alter the behavior of migrating deer and diminish the foraging benefit of migration, with potential to cause longterm decline of migratory herds.

\section{Contact}

Matthew Kauffman, USGS Wyoming Cooperative Fish and Wildlife Research Unit, mkauffm1@uwyo.edu, (307) 766-6404

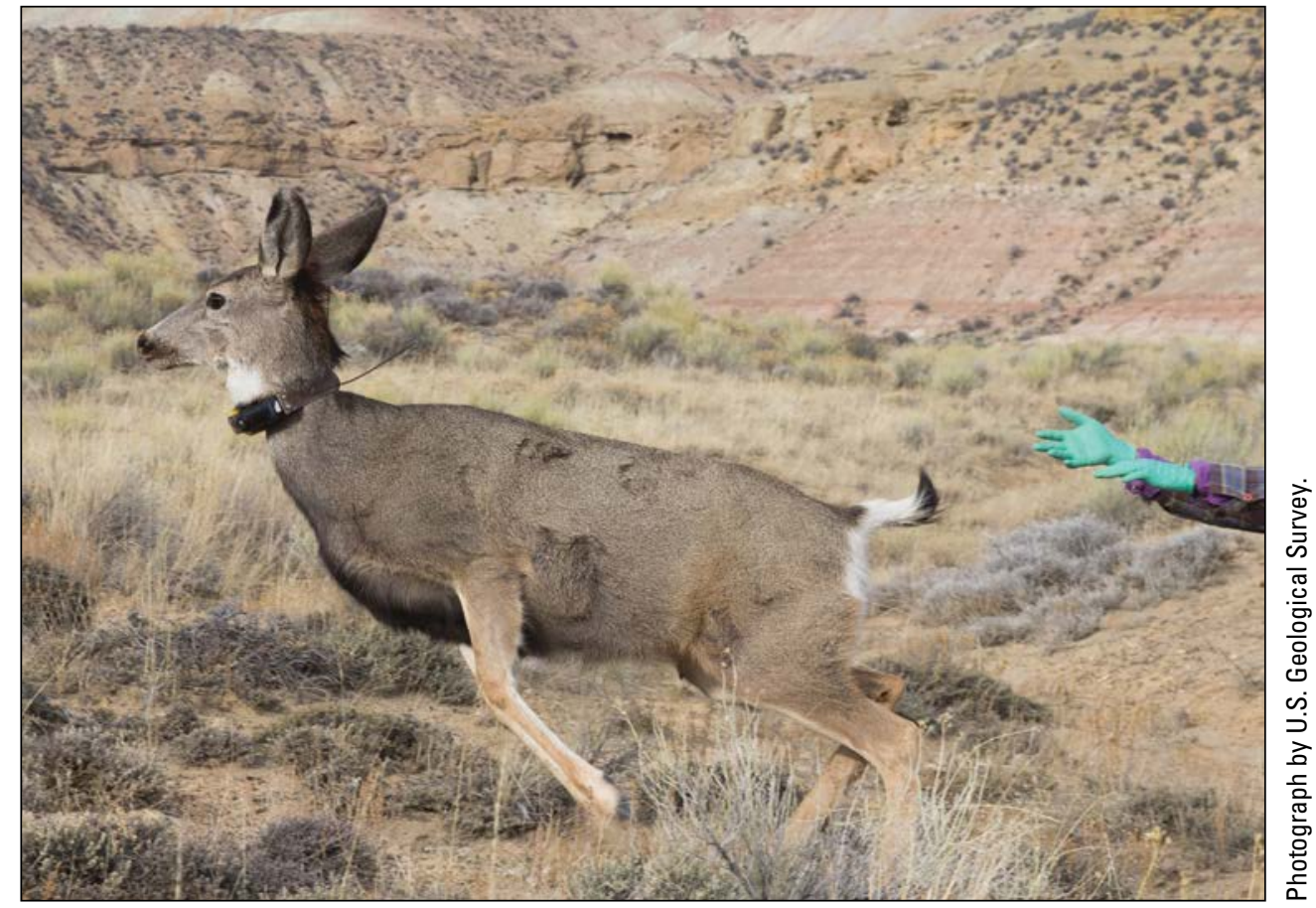

A scientist with the Wyoming Cooperative Fish and Wildlife Research Unit releases a collared mule deer.

\section{Florida Manatee Movement and Habitat Use in the Northern Gulf of Mexico}

The USGS is collecting data related to Florida manatee distribution and their use of habitat and travel corridors in the northern Gulf of Mexico (GOM). Manatees known to travel to the northern GOM are being captured for health assessment and tracked with GPS telemetry to acquire fine-scale habitat use and movement information. Field studies focus on characterization of local resources in areas with appropriate habitat or consistent manatee use. The data collected are being used to inform risk of interactions between manatees and vessels traveling through coastal areas to and from oil and gas structures.

\section{Contact}

Daniel Slone, USGS Wetland and Aquatic Research Center, dslone@usgs.gov, (352) 264-3551

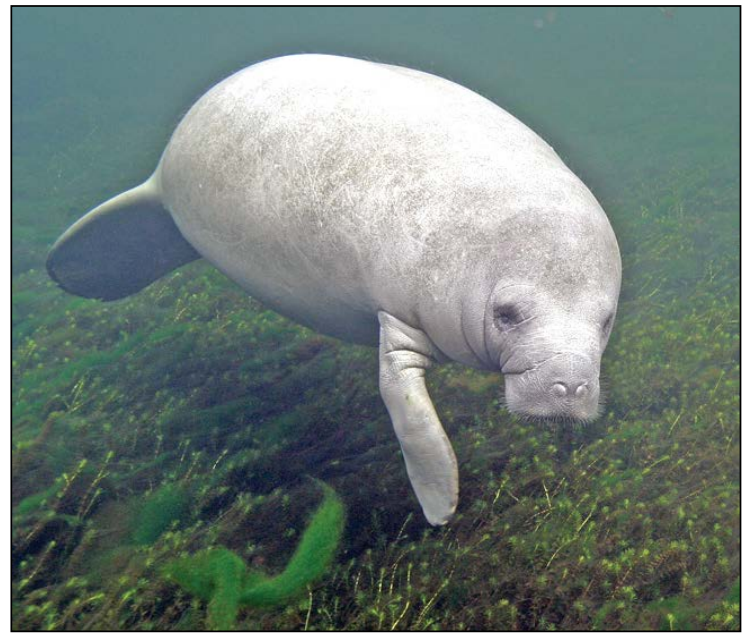

Florida manatee. 


\section{Gulf of Mexico Marine Assessment Program for Protected Species: Sea Turtles}

The Gulf of Mexico Marine Assessment Program for Protected Species (GoMMAPPS) is a multiagency partnership between the BOEM, USFWS, National Oceanic and Atmospheric Administration (NOAA), and USGS with the goal of collecting broad-scale surveys for protected species to inform the distribution and abundance of marine animals across years and seasons. The USGS is leading efforts to provide information on abundance, distribution, and movement patterns of sea turtles. Some of the most severe gaps in knowledge of marine turtle ecology occur in areas of heavy oil and gas use, including BOEM's Central and Western Planning Areas. These data can be used in support of various BOEM/Bureau of Safety and Environmental Enforcement (BSEE) activities, including oil spill risk analysis, decommissioning of oil platforms, and movements of vessels.

\section{Contacts}

Kristen M. Hart, USGS Wetland and Aquatic Research Center, Kristen_hart@usgs.gov, (954) 377-5922

Margaret M. Lamont, USGS Wetland and Aquatic Research Center, mlamont@usgs.gov, (352) 209-4306

\section{Sea Turtle Movements and Habitat Use in the Northern Gulf of Mexico}

The USFWS and U.S. National Marine Fisheries Service (NMFS) identified that information on the distribution, seasonal movements, vital rates, and habitat use for all life stages of marine turtles is needed to recover these endangered species. The USGS is deploying satellite tags capable of logging dive data along with state-of-the-art acceleration data loggers on turtles to obtain fine-scale information on their dive profiles in the Gulf of Mexico. These data provide information on depth use, movement patterns, mortality risk, utilization of post-dredge sites, use of preferred thermal zones, and time spent near the vicinity of dredging activities which impacts mortality and entrainment risk of juveniles, sub-adults, and adult Kemp's ridleys, loggerheads, and green sea turtles. This study can directly address recovery and protection goals and provide information on in-water aggregations of sub-adult, juvenile, and adult marine turtles in the Gulf of Mexico.

\section{Contacts}

Kristen M. Hart, USGS Wetland and Aquatic Research Center, Kristen_hart@usgs.gov, (954) 377-5922

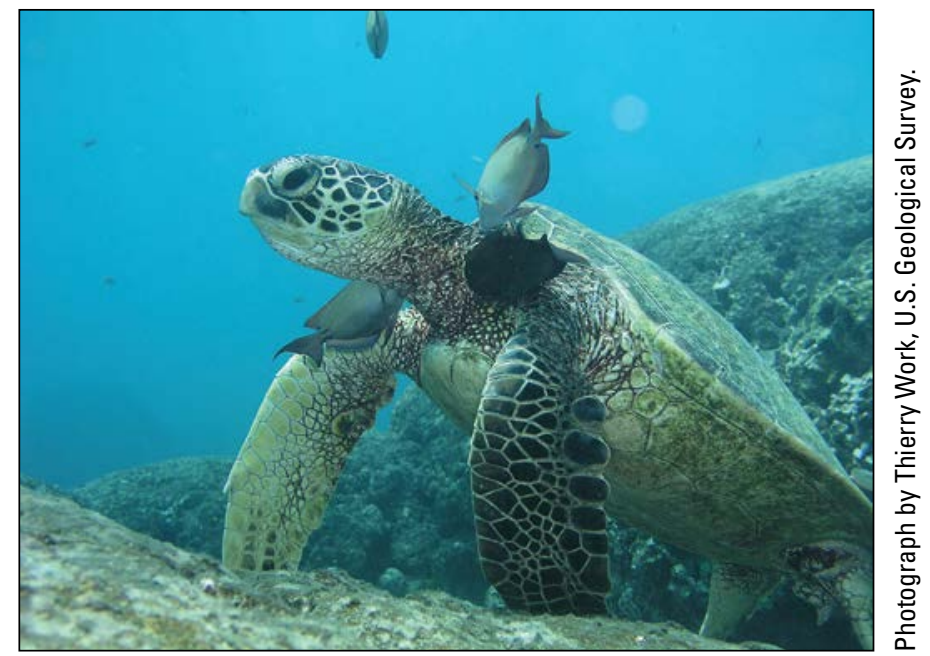

Green sea turtle.

Margaret M. Lamont, USGS Wetland and Aquatic Research Center, mlamont@usgs.gov, (352) 209-4306

\section{Canid Distribution and the Potential Impacts of Energy Development in Nebraska}

The USGS, in collaboration with the Nebraska Game and Parks Commission, the Nebraska Department of Roads, the Nebraska Environmental Trust, the U.S. Forest Service, Chadron State College, and the University of Nebraska, is implementing a comprehensive survey and monitoring plan for the swift fox across 67,000 square kilometers (26,000 square miles) of western Nebraska. The goal of the Nebraska Canid Project is to document the current distribution and ecological requirements of the swift fox and explore how infrastructure development may alter future habitat conditions and subsequently Nebraska's canid communities by creating and testing a series of predictive species distribution models. The resulting models can be used as a decision-support tool to assist policymakers and management agencies in future energy siting decisions.

\section{Contact}

Joseph J. Fontaine, USGS Nebraska Cooperative Fish and Wildlife Research Unit, jfontaine2@unl.edu, (402) 472-0339 

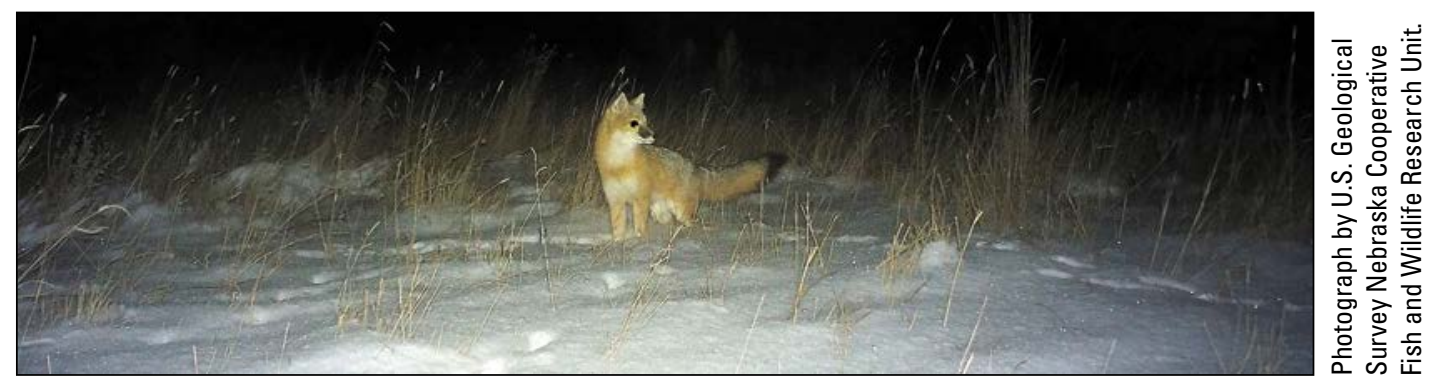

Swift fox captured by a trail camera in western Nebraska.

\section{Potential Effects of Wind Farms on Montane Carnivores in New England}

With the increasing need for, and opportunities to site, wind farms in high-elevation New England forests, there is a need to understand the effects of the associated infrastructure on populations of animals otherwise expected to be impacted by climate change. A study by the USGS Northeast Climate Science Center was conducted to examine the effect wind farms would have on montane carnivores in New England with suggestions for siting, road construction, and minimized impacts on habitats considered climate refugia.

\section{Contact}

Mary Ratnaswamy, USGS Northeast Climate Science Center, mratnaswamy@usgs.gov, (413) 545-3424

\section{Publication}

Sirén, A.P.K., Pekins, P.J., Kilborn, J.R., Kanter, J.J., and Sutherland, C.S., 2017, Potential influence of high-elevation wind farms on carnivore mobility: Journal of Wildlife Management, prepublication early view, https://doi.org/10.1002/jwmg.21317.

\section{Measure Impacts}

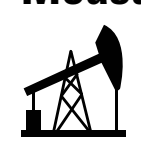

\section{Quantifying Response of Pacific Walrus to Ocean Noise in the Arctic}

Walruses spend the vast majority of their time in water. As with other marine mammals, their underwater acoustic environment enables them to communicate with one another and respond to disturbance. The USGS is using telemetry data and remote sensing information of sea ice and other environmental variables to study the effects of ocean noise from vessel traffic and offshore industrial activities on Pacific walrus activity patterns. Models are being developed to link levels of activity patterns to walrus energy expenditures and their potential effect on walrus rates of reproduction and survival. The results of these studies can be used to quantify the potential population-level impacts to walruses from offshore oil and gas development and associated support vessels off the coast of arctic Alaska.

\section{Contact}

Grant Hilderbrand, USGS Alaska Science Center, ghilderbrand@usgs.gov, (907) 786-7076

\section{Publications}

Taylor, R.L., Udevitz, M.S., Jay, C.V., Citta, J.J., Quakenbush, L.T., Lemons, P.R., and Snyder, J.A., in press, Demography of the Pacific walrus (Odobenus rosmarus divergens) in a changing Arctic: Marine Mammal Science, prepublication early view, https://doi.org/10.1111/mms.12434.

Jay, C.V., Taylor, R.L., Fischbach, A.S., Udevitz, M.S., and Beatty, W.S., 2017, Walrus haul-out and in water activity levels relative to sea ice availability in the Chukchi Sea: Journal of Mammalogy, v. 98, no. 2, p. 386-396, https://doi.org/10.1093/ jmammal/gyw195.

Beatty, W.S., Jay, C.V., and Fischbach, A.S., 2016, An evaluation of behavior inferences from Bayesian state-space models-A case study with the Pacific walrus: Marine Mammal Science, v. 32, no. 4, p. 1299-1318, https://doi.org/10.1111/mms.12332.

Mouy, Xavier, Delarue, Julien, Martin, Bruce, Hannay, David, Jay, Chadwick, and Fischbach, Anthony, 2014, Real-time acoustic monitoring and source level estimates of walruses in the northeastern Chukchi Sea using particle velocity sensors: The Journal of the Acoustical Society of America, v. 135, no. 4, p. 2361-2361, https://doi.org/10.1121/1.4877780. 


\section{Measuring Impacts of Industrial Activities on Polar Bears}

The USGS is focused on characterizing changes in the abundance, distribution, and health of polar bears relative to human activities in the Arctic, with an emphasis on identifying critical habitats that are potentially at risk of disturbance from industrial activities along Alaska's arctic coast. This work has informed efforts of the Department of the Interior (DOI) agencies and industry when considering the consequences of oil spills and exposures to pollutants and actions to mitigate such occurrences. The USGS continues to work closely with its DOI and industry partners to identify circumstances in which industrial activities are likely to adversely affect polar bears. Future work is expected to focus on the potential for resource development activities on land and offshore to directly and indirectly affect polar bear behavior and health.

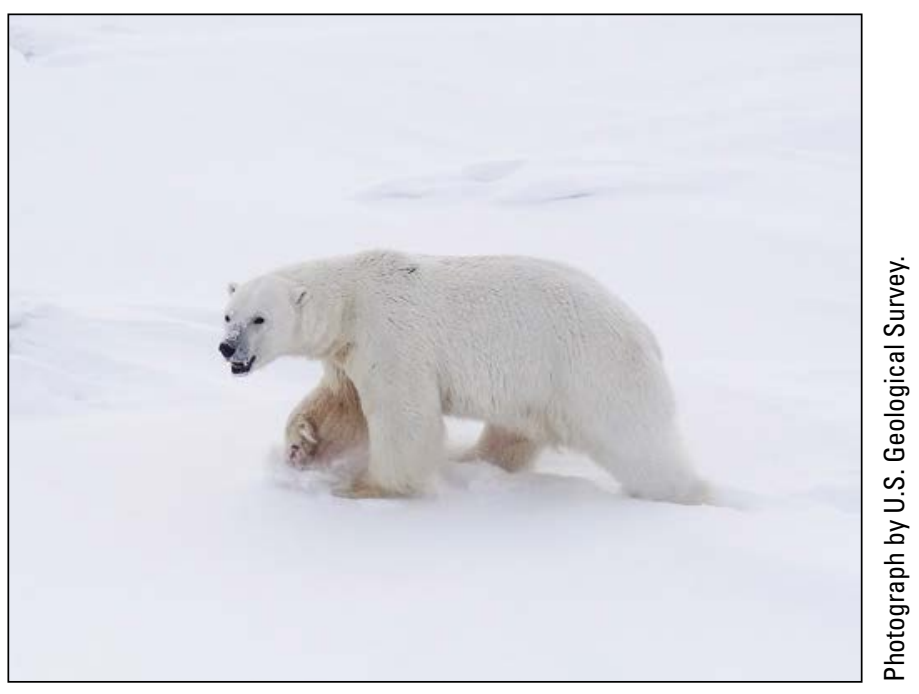

Polar bear.

\section{Contact}

Grant Hilderbrand, USGS Alaska Science Center, ghilderbrand@usgs.gov, (907) 786-7076

\section{Publications}

McKinney, M.A., Atwood, T.C., Iverson, S.J., and Peacock, Elizabeth, 2017, Temporal complexity of southern Beaufort Sea polar bear diets during a period of increasing land use: Ecosphere, v. 8, no. 1, e01633, https://doi.org/10.1002/ecs2.1633.

McKinney, M.A., Atwood, T.C., Pedro, Sara, and Peacock, Elizabeth, 2017, Ecological change drives a decline in mercury concentrations in southern Beaufort Sea polar bears: Environmental Science and Technology, v. 51, no. 14, https://doi.org/10.1021/acs.est.7b00812.

Atwood, T.C., Marcot, B.G., Douglas, D.C., Amstrup, S.C., Rode, K.D., Durner, G.M., and Bromaghin, J.F., 2016, Forecasting the relative influence of environmental and anthropogenic stressors on polar bears: Ecosphere, v. 11, no. 6, e01370, https://doi.org/10.1002/ecs2.1370.

Atwood, T.C., Peacock, Elizabeth, McKinney, M.A., Lillie, Kate, Wilson, R.R., Douglas, D.C., Miller, Susanne, and Terletzky, Pat, 2016, Rapid environmental change drives increased land use by an Arctic marine predator: PLOS ONE, v. 11, no. 6, e0155932, https://doi.org/10.1371/journal.pone.0155932.

Bowen, Lizabeth, Miles, A.K., Stott, Jeffrey, Waters, Shannon, and Atwood, T.C., 2015, Enhanced biological processes associated with alopecia in polar bears (Ursus maritimus): Science of the Total Environment, v. 529, p. 114-120, https://doi.org/10.1016/j.scitotenv.2015.05.039.

Bowen, Lizabeth, Miles, A.K., Waters, Shannon, Meyerson, Randi, Rode, Karyn, and Atwood, Todd, 2015, Gene transcription in polar bears (Ursus maritimus) from disparate populations: Polar Biology, v. 38, no. 9, https://doi.org/10.1007/s00300-015-1705-0.

Rode, K., Wilson, R.R., Regehr, E.V., St. Martin, Michelle, Douglas, D.C., and Olson, Jay, 2015, Increased land use by Chukchi Sea polar bears in relation to changing sea ice conditions: PLOS ONE, v. 10, no. 11, e0142213, https://doi.org/10.1371/journal.pone.0142213.

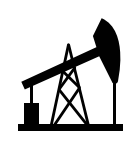

\section{Pygmy Rabbit Presence and Abundance in Relation to Gas Field Development}

Areas of the sagebrush steppe landscape, where gas field development is occurring, harbor 24 sagebrush-associated species of greatest conservation need. To examine the effects of gas field development density on pygmy rabbits, USGS scientists collected 3 years of survey data on pygmy rabbit site occupancy patterns at four major Wyoming gas fields. The study concluded that pygmy rabbits in southwestern Wyoming may suffer local population declines at lower levels of development than are allowed in existing plans and policies designed to conserve greater sage-grouse by limiting the surface footprint of energy development. Buried utilities, gas well pads, areas adjacent to well pads, and well pad access roads had the strongest negative correlation with pygmy rabbit presence and abundance. Minimizing the surface footprint of these elements may reduce negative impacts of gas energy development on pygmy rabbits. 


\section{Contact}

Stephen Germaine, USGS Fort Collins Science Center, germaines@usgs.gov, (970) 226-9107

\section{Publication}

Germaine, S.S., Carter, S.K., Ignizio, D.A., and Freeman, A.T., 2017, Relationships between gas field development and the presence and abundance of pygmy rabbits in southwestern Wyoming: Ecosphere, v. 8, no. 5, e01817, 19 p., https://doi.org/10.1002/ecs2.1817.

\section{Inform Solutions}

\section{Distribution and Abundance of Pacific Walrus in Relation to Offshore Development in Alaska}

Increasing ice-free periods in the Arctic create greater opportunities for offshore oil and gas development in the Chukchi Sea, Alaska. These activities, and their reliance on onshore infrastructure and shipping, require information on the distribution of Pacific walrus and their habitats to identify ways for industry to operate effectively while meeting conservation goals set by government agencies. USGS scientists developed novel satellite radio tracking devices to map feeding areas used by walruses that were used by the U.S. Navy and by the U.S. Coast Guard for managing corridors of vessel transit. Scientists are now developing ways to use unmanned aircraft systems to estimate the abundance and distribution of Pacific walruses and their habitats in the Chukchi Sea. These studies have informed incidental take regulations and mitigation measures that can guide offshore development in minimizing their interactions with walrus foraging and resting areas.

\section{Contact}

Grant Hilderbrand, USGS Alaska Science Center, ghilderbrand@usgs.gov, (907) 786-7076

\section{Publications}

Battaile, B.C., Jay, C.V., Udevitz, M.S., and Fischbach, A.S., 2017, Evaluation of a method using survey counts and tag data to estimate the number of Pacific walruses (Odobenus rosmarus divergens) using a coastal haulout in northwestern Alaska: Polar Biology, v. 40, no. 7, https://doi.org/10.1007/s00300-016-2060-5.

Beatty, W.S., Jay, C.V., Fischbach, A.S., Grebmeier, J.M., Taylor, R.L., Blanchard, A.L., and Jewett, S.C., 2016, Space use of a dominant Arctic vertebrate-Effects of prey, sea ice, and land on Pacific walrus resource selection: Biological Conservation, v. 203, p. 25-32, https://doi.org/10.1016/j.biocon.2016.08.035.

Fischbach, Anthony, and Jay, C.V., 2016, A strategy for recovering continuous behavioral telemetry data from Pacific walruses: Wildlife Society Bulletin, v. 40, no. 3, p. 599-604, https://doi.org/10.1002/wsb.685.

Fischbach, A.S., Kochnev, A.A., Garlich-Miller, J.L., and Jay, C.V., 2016, Pacific walrus coastal haulout database, 1852-2016-Background report: U.S. Geological Survey Open-File Report 2016-1108, 27 p., https://doi.org/10.3133/ofr20161108.

Jay, C.V., Fischbach, A.S., and Kochnev, A.A., 2012, Walrus areas of use in the Chukchi Sea during sparse sea ice cover: Marine Ecology Progress Series, v. 468, p. 1-13, https://doi.org/10.3354/meps10057.

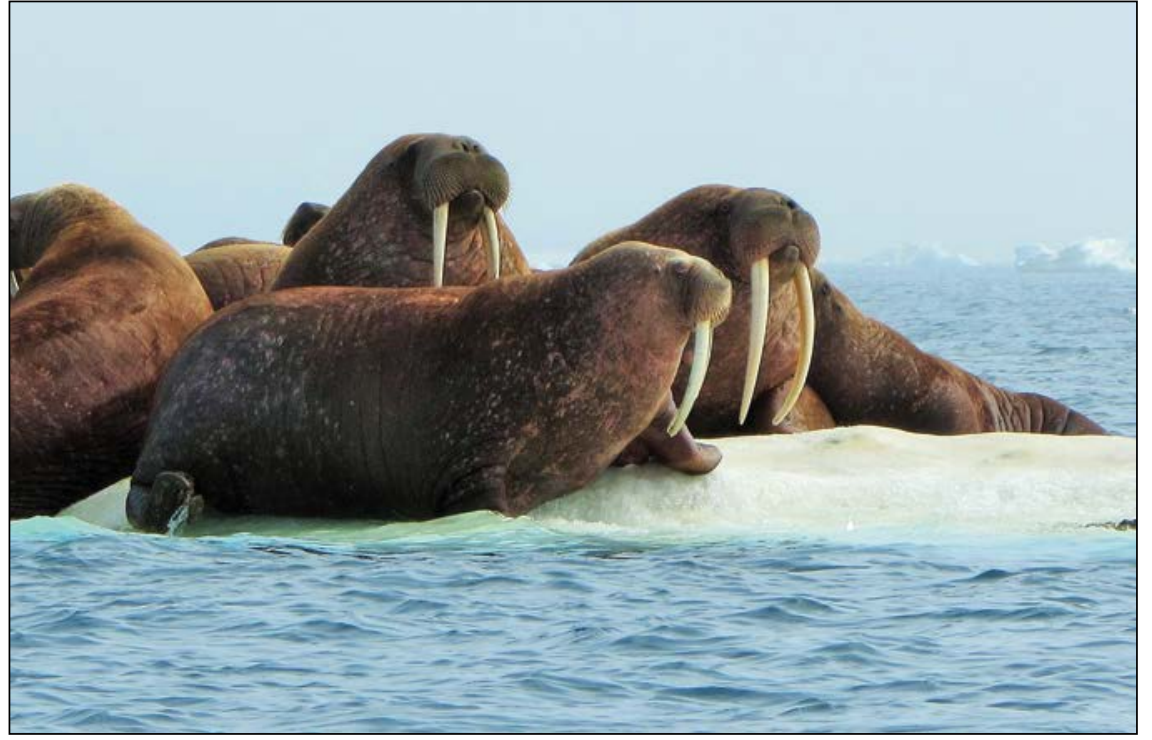

Pacific walrus resting on a piece of sea ice in the Chukchi Sea. 


\section{Mitigating the Impacts of Energy Development on Polar Bears}

USGS works closely with DOI agencies to identify science needs that inform mitigation actions from the impacts of energy development on polar bears. Science information collected by the USGS is used by (1) USFWS to guide regulations regarding the incidental take of polar bears by industry, (2) BLM to mitigate the effects of energy development on polar bears that den within the National Petroleum Reserve-Alaska, and (3) BOEM to guide decisions regarding permitting of offshore oil and gas exploration and extraction. Future USGS work is focusing on improving decision-making tools for these agencies to assess the relative importance of environmental and anthropogenic stressors to polar bear population persistence.

\section{Contact}

Grant Hilderbrand, USGS Alaska Science Center, ghilderbrand@usgs.gov, (907) 786-7076

\section{Publications}

Kohout, Jenifer, Runge, M.C., Wilder, Jim, Atwood, Todd, Colligan, Mary, Douglas, Dave, Oakley, Karen, Regehr, Eric, Rode, Karyn, Servheen, Christopher, Sparks, Rhonda, Titus, Kim, and Wilson, Ryan, 2017, Polar Bear Conservation Management Plan, Final: U.S. Fish and Wildlife Service, Region 7, Anchorage, Alaska, 104 p., https:/www.fws.gov/alaska/fisheries/mmm/ polarbear/pdf/PBRT_Recovery_\%20Plan_Book_FINAL_signed.pdf.

Olson, J.W., Rode, K.D., Eggett, D., Smith, T.S., Wilson, R.R., Durner, G.M., Fischbach, A., Atwood, T.C., and Douglas, D.C., 2017, Collar temperature sensor data reveal long-term patterns in southern Beaufort Sea polar bear den distribution on pack ice and land: Marine Ecology Progress Series, v. 564, p. 211-224, https://doi.org/10.3354/meps12000.

Atwood, T.C., Marcot, B.G., Douglas, D.C., Amstrup, S.C., Rode, K.D., Durner, G.M., and Bromaghin, J.F., 2016, Forecasting the relative influence of environmental and anthropogenic stressors on polar bears: Ecosphere, v. 7, no. 6, e01370, https://doi.org/10.1002/ecs2.1370.

Durner, G.M., Simac, Kristin, and Amstrup, S.C., 2013, Mapping polar bear maternal denning habitat in the National Petroleum Reserve-Alaska with an IfSAR digital terrain model: ARCTIC, v. 66, no. 2, p. 197-206, https://doi.org/10.14430/arctic4291.

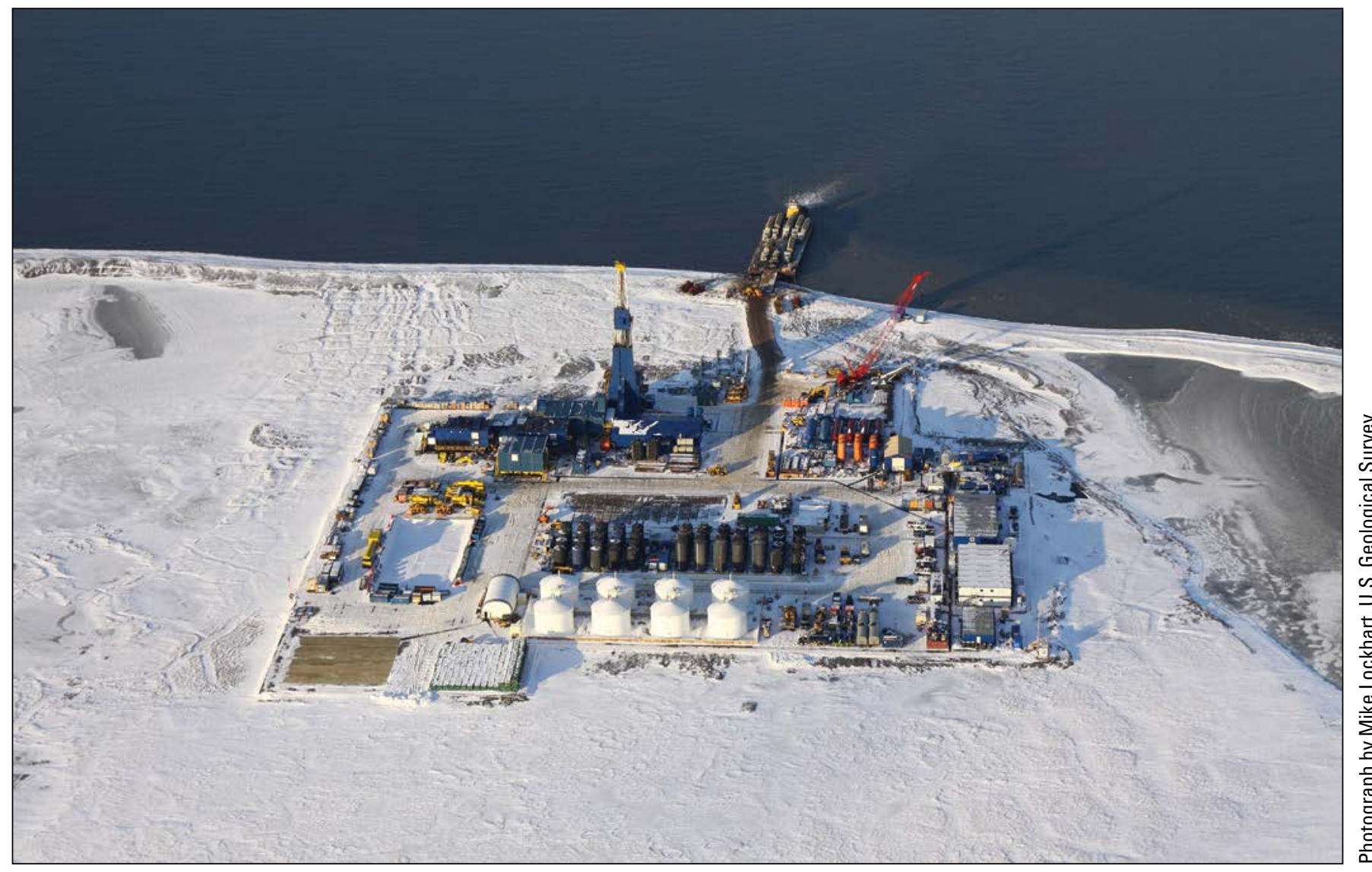

Aerial view of an industrial plant near the shore in Alaska, October 2009. 


\section{Effects of Changes in Coastal Florida Power Generation on Florida Manatees}

The USGS, in collaboration with the Florida Fish and Wildlife Conservation Commission, completed a population viability analysis for the Florida manatee that included investigating threats to the persistence of the species. In coastal Florida, some manatees rely on warm-water effluents from power generation stations. These effluents are expected to disappear as plants reach the end of their operating lives, potentially exposing manatees to greater risk during the winter months. As part of the viability analysis, the USGS investigated the risk associated with different rates of loss of warm-water habitat for manatees associated with powerplant operations. The results suggested that, although loss of industrial warm-water effluent poses shortterm risk to individual manatees, the long-term risk to the subspecies is small, producing only small increases in risk to the subspecies. In March 2017, the USFWS reclassified the West Indian manatee from endangered to threatened, based, in part, on the scientific analysis by the USGS.

\section{Contacts}

Catherine Langtimm, USGS Wetland and Aquatic Research Center, clangtimm@usgs.gov, (352) 264-3489

Michael Runge, USGS Patuxent Wildlife Research Center, mrunge@usgs.gov, (301) 497-5748

\section{Publications}

Runge, M.C., Sanders-Reed, C.A., Langtimm, C.A., Hostetler, J.A., Martin, Julien, Deutsch, C.J., Ward-Geiger, L.I., and Mahon, G.L., 2017, Status and threats analysis for the Florida manatee (Trichechus manatus latirostris), 2016: U.S. Geological Survey Scientific Investigations Report 2017-5030, https://doi.org/10.3133/sir20175030.

Langtimm, C.A., Kendall, W.L., Beck, C.A., Kochman, H.I., Teague, A.L., Meigs-Friend, Gaia, and Peñaloza, C.L., 2016, Model description and evaluation of the mark-recapture survival model used to parameterize the 2012 status and threats analysis for the Florida manatee (Trichechus manatus latirostris): U.S. Geological Survey Open-File Report 2016-1163, https://doi.org/10.3133/ofr20161163.

Peñaloza, C.L., Kendall, W.L., and Langtimm, C.A., 2014, Reducing bias in survival under nonrandom temporary emigration: Ecological Applications, v. 24, no. 5, p. 1155-1166, https://doi.org/10.1890/13-0558.1.

Kendall, W.L., Barker, R.J., White, G.C., Lindberg, M.S., Langtimm, C.A., and Peñaloza, C.L., 2013, Combining dead recovery, auxiliary observations and robust design data to estimate demographic parameters from marked individuals: Methods in Ecology and Evolution, v. 4, no. 9, p. 828-835, https://doi.org/10.1111/2041-210X.12077.

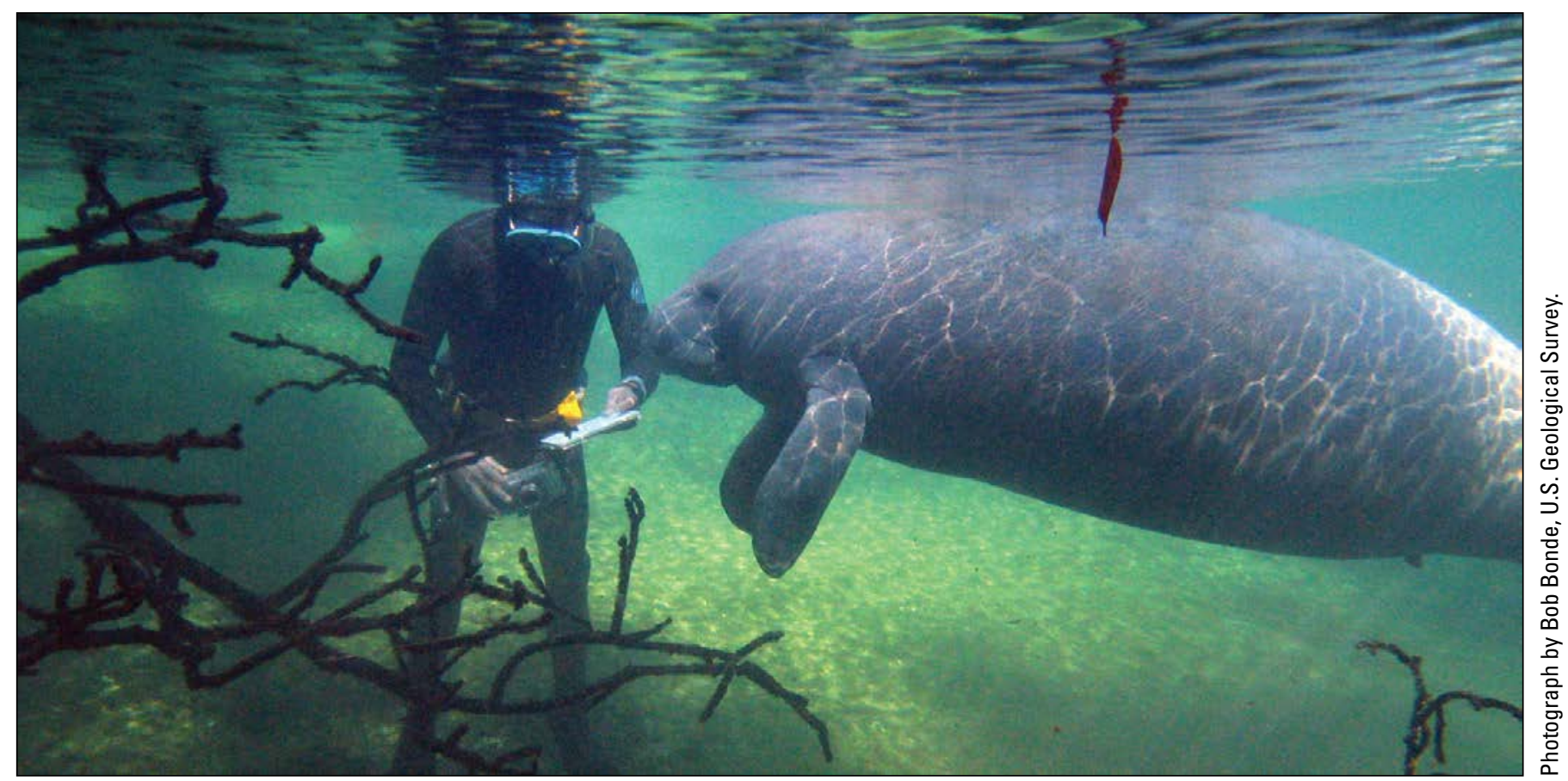

USGS researcher collects data on manatee in a Florida spring. 


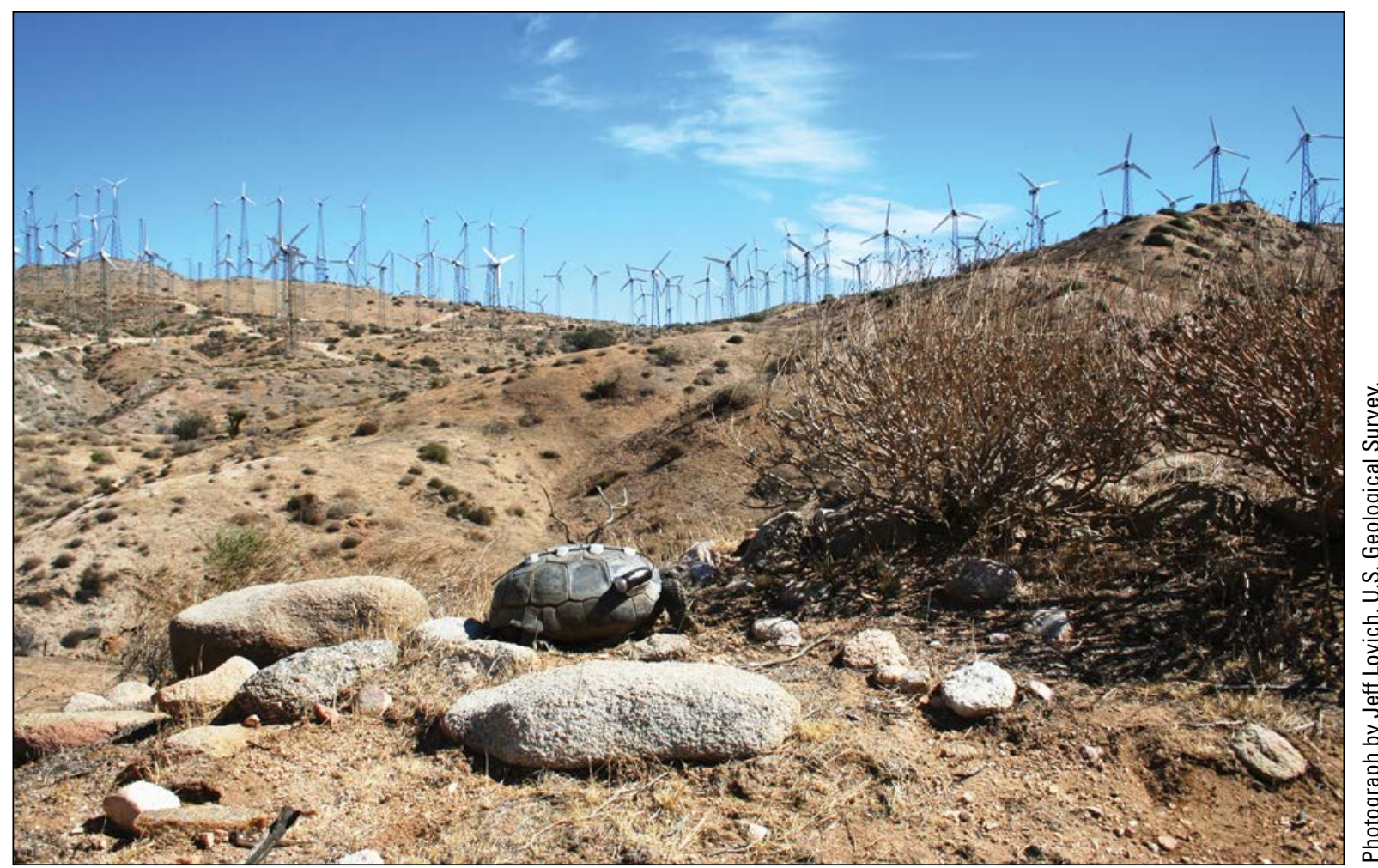

Desert tortoise with radio transmitter on a wind farm.

\section{Desert Tortoise}

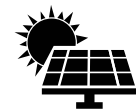

\section{Effects of Solar Development and Habitat Alterations on Desert Tortoises}

The Ivanpah Valley in southeastern California and southern Nevada is a hotspot of genetic diversity and connectivity for Agassiz's desert tortoise that overlaps with utility-scale solar development. The USGS, University of Nevada at Reno, and partners are developing and applying novel tracking, genetic tagging, and biomarkers for assessing movement, health, and population connectivity in the valley relative to landscape features and renewable energy development that promote or impede population connectivity.

\section{Contacts}

Todd Esque, USGS Western Ecological Research Center, tesque@usgs.gov, (702) 564-4506

Amy Vandergast, USGS Western Ecological Research Center, avandergast@usgs.gov, (619) 225-6445

\section{Publications}

Drake, K.K., Bowen, Lizabeth, Lewison, R.L., Esque, T.C., Nussear, K.E., Braun, Josephine, Waters, S.C., and Miles. A.K., 2017, Coupling gene-based and classic veterinary diagnostics improves interpretation of health and immune function in the Agassiz's desert tortoise (Gopherus agassizii): Conservation Physiology, v. 5, no. 1, 17 p., https://doi.org/10.1093/conphys/ cox037.

Drake, K.K., Bowen, Lizabeth, Nussear, K.E., Esque, T.C., Berger, A.J., Custer, N.A., Waters, S.C., Johnson, J.D., Miles, A.K., and Lewison, R.L., 2016, Negative effects of invasive plants on conservation of sensitive desert wildlife: Ecosphere, v. 7 , no. 10, e01531, https://doi.org/10.1002/ecs2.1531.

Bowen, Lizabeth, Miles, A.K., Drake, K.K., Waters, S.C., Esque, T.C., and Nussear, K.E., 2015, Integrating gene transcription-based biomarkers to understand desert tortoise and ecosystem health: Ecohealth, v. 12, no. 3, p. 501-512, https://doi.org/10.1007/s10393-014-0998-8. 


\section{Interactions of Desert Tortoises With Wind Energy}

From 1995 to 2013, the USGS has studied the ecology of a population of federally protected Agassiz's desert tortoises at a wind facility on land managed by the BLM near Palm Springs, California. To support recovery efforts for the species, almost 130 tortoises were marked between 1997 and 2000, providing a unique opportunity to examine the growth, demography, habitat selection, and survivorship of this long-lived species. Ongoing analyses of those data continue and are focused on the effects of turbine-induced fire on the ecology and behavior of tortoises, genetic characteristics of the population, and the apparent lack of significant recruitment into the population.

\section{Contact}

Jeffrey Lovich, USGS Southwest Biological Science Center, jeffrey_lovich@usgs.gov, (928) 556-7358

\section{Publications}

Agha, Mickey, Smith, A.L., Lovich, J.E., Delaney, David, Ennen, J.R., Briggs, Jessica, Tennant, L.A., Puffer, S.R., Walde, Andrew, Arundel, T.R., Price, S.J., and Todd, B.D., 2017, Mammalian mesocarnivore visitation at tortoise burrows in a wind farm: Journal of Wildlife Management, v. 81, no. 6, p. 1117-1124, https://doi.org/10.1002/jwmg.21262.

Ennen, J.R., Lovich, J.E., Averill-Murray, R.C., Yackulic, C.B., Agha, Mickey, Loughran, Caleb, Tennant, Laura, and Sinervo, Barry, 2017, The evolution of different maternal investment strategies in two closely related desert vertebrates: Ecology and Evolution, v. 7, no. 9, p. 3177-3189, https://doi.org/10.1002/ ece3.2838.

Lovich, J.E., and Ennen., J.R., 2017, Reptiles and amphibians, in Perrow, M.R., Wildlife and windfarms, conflicts and solutions, v. 1, Onshore-Potential effects: Exeter, U.K., Pelagic Press, p. 97-118.

Lovich, J.E., and Ennen, J.R., 2016, Energy development, in Jones, L.L.C., Halama, K.J., and Lovich, R.E., eds., Habitat management guidelines for amphibians and reptiles in the Southwestern United States: Birmingham, Ala., Partners in Amphibian and Reptile Conservation, Technical Publication HMG-5, 193 p.

Lovich, J.E., 2015, Case study-Road proliferation due to rapid renewable energy development, in Andrews, K.A., Nanjappa, Priya, and Riley, S.P.D., eds., Roads and ecological infrastructure-Concepts and applications for small animals: Baltimore, Md., Johns Hopkins University Press and The Wildlife Society, p. 79-84.

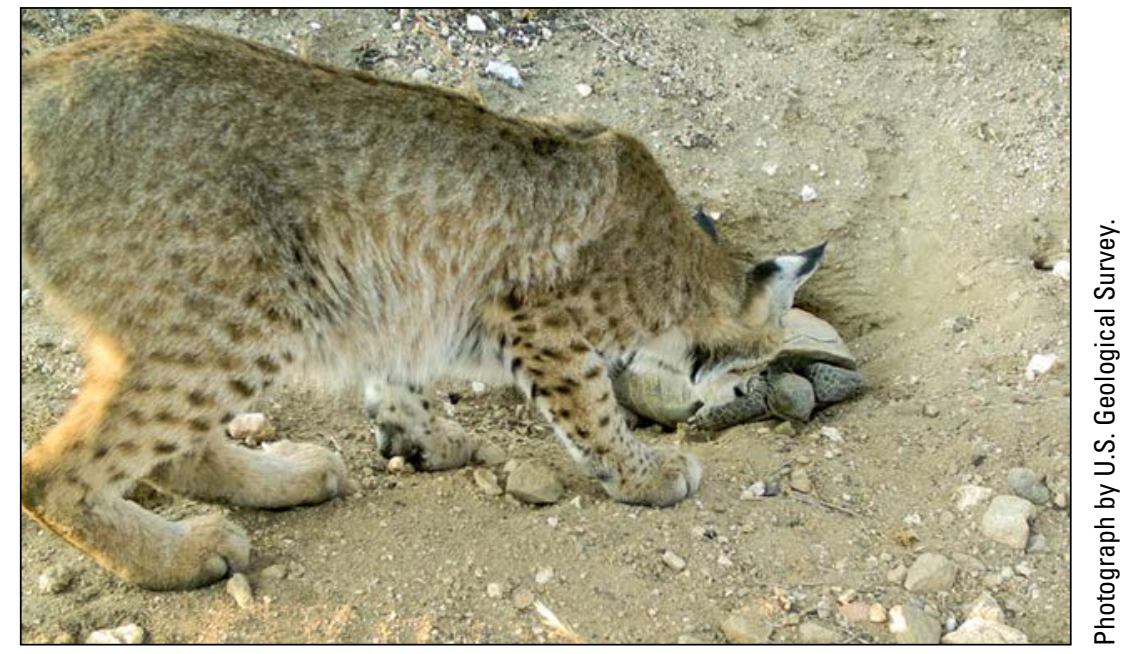

A bobcat approaches a desert tortoise sleeping on the apron of her burrow. This image was taken with a motion-sensor camera placed facing the entrance of the burrow at a wind energy facility near Palm Springs, California.

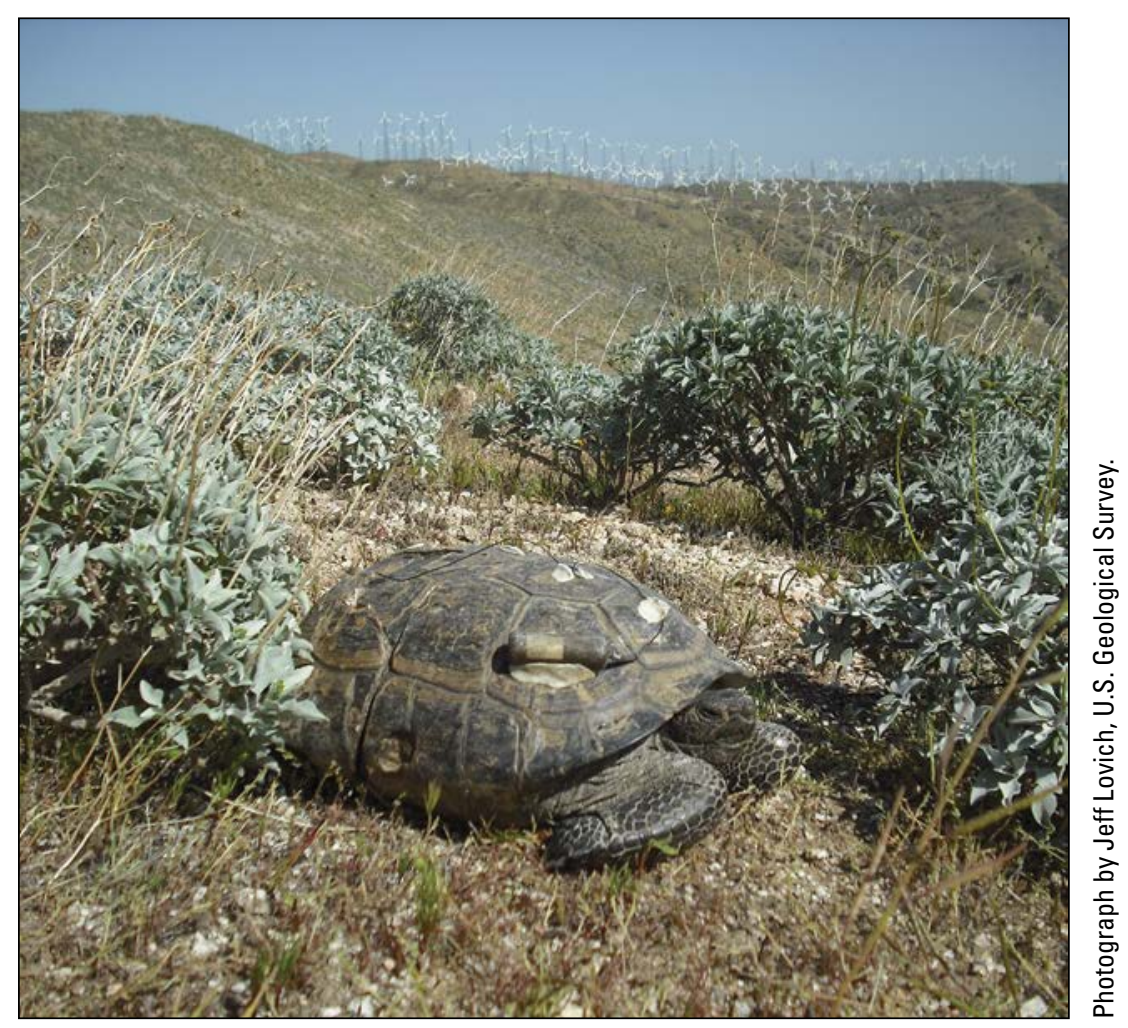

Desert tortoise with a radio transmitter near Palm Springs, California. 


\section{Desert Tortoise Disease Risks Associated with Translocations}

Renewable energy projects in southern California are frequently sited in desert tortoise habitat, creating the need to translocate tortoises to new areas. In a pre-translocation study of more than 1,000 desert tortoises in the central Mojave Desert, prevalence of upper respiratory tract diseases (URTD) was higher in tortoises living close to human settlements or towns. Bacterial-related URTD probably entered wild tortoise populations through released or escaped captive turtles and tortoises, in which such diseases are common. These findings have significant implications for wildlife and land management decisions regarding site selection for tortoise translocations.

Contact

Kristin H. Berry, USGS Western Ecological Research Center, kristin_berry@usgs.gov, (951) 697-5361

Publication

Berry, K.H., Coble, A.A., Yee, J.L., Mack, J.S., Perry, W.M., Anderson, K.M., and Brown, M.B., 2015, Distance to human populations influences epidemiology of respiratory disease in desert tortoises: Journal of Wildlife Management, v. 79, no. 1, p. 122-136, https://doi.org/10.1002/jwmg.816.

\section{Shelter Choices for Tortoises During Temperature Extremes}

Desert tortoises spend more than 90 percent of their lives underground in shelters that buffer the extremes of climate. To learn more about the characteristics of these shelters, USGS scientists monitored temperatures at 30 active burrows and dens used by adult desert tortoises in the Soda Mountains, California. Temperatures inside the shelters were largely influenced by tunnel length, width of the shelter openings, and soil cover. As tunnel length increased, the effects of temperature extremes were dampened and became more stable. With projected increasing temperatures, habitats with terrain and underlying surficial geology that sustain shelters with long tunnels and expanded openings could benefit desert tortoises. Managers may use these findings to make decisions about habitat for translocation, acquisition, connectivity, and other recovery efforts.

Contact

Kristin H. Berry, USGS Western Ecological Research Center, kristin_berry@usgs.gov, (951) 697-5361

\section{Publication}

Mack, J.S., Berry, K.H., Miller, D.M., and Carlson, A.S., 2015, Factors affecting the thermal environment of Agassiz's desert tortoise (Gopherus agassizii) cover sites in the central Mojave Desert during periods of temperature extremes: Journal of Herpetology, v. 49, no. 3, p. 405-414, https://doi.org/10.1670/13-080.

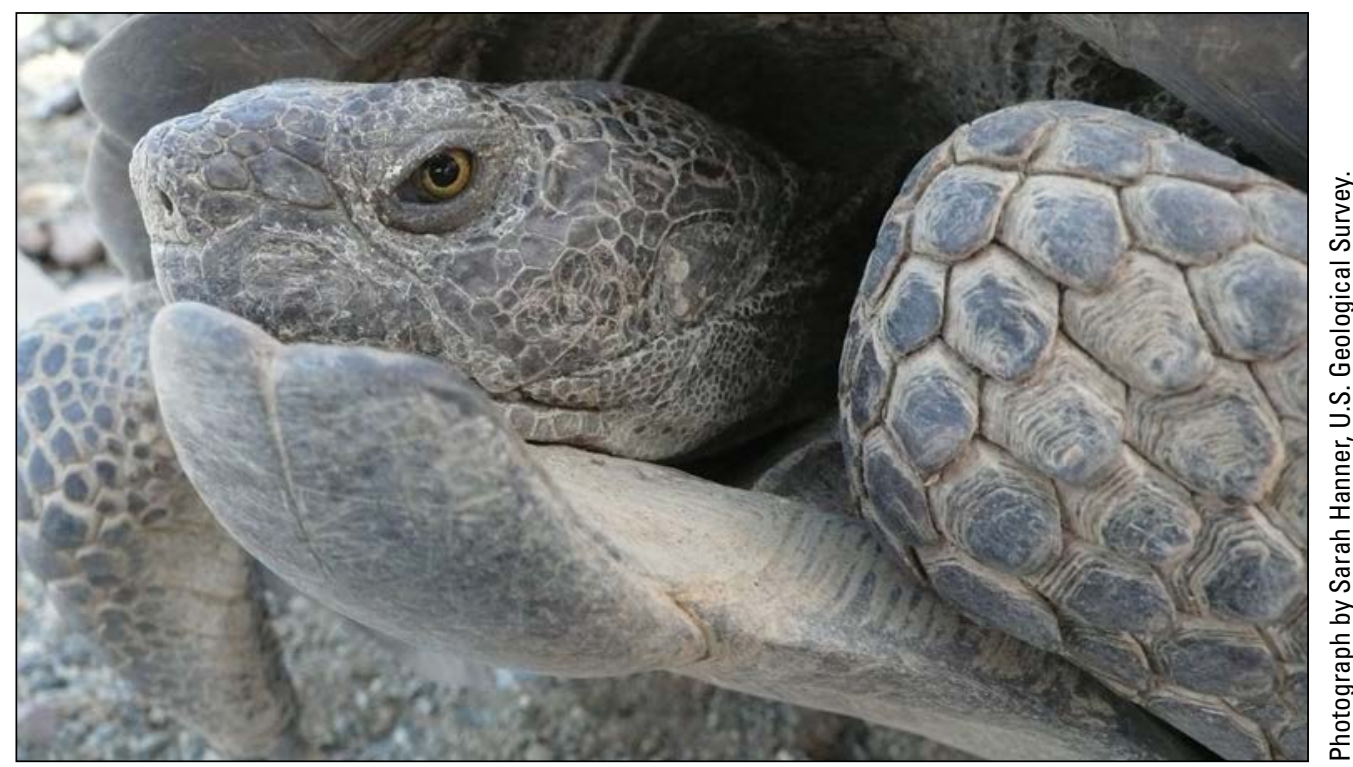

Adult male desert tortoise in central Mojave Desert, San Bernardino County, California. 


\section{Additional Publications About the Desert Tortoise}

Berry, K.H., Lyren, L.M., Mack, J.S., Brand, L.A., and Wood, D.A., 2016, Desert tortoise annotated bibliography, 1991-2015: U.S. Geological Survey Open-File Report 2016-1023, 312 p., https://doi.org/10.3133/ofr20161023.

Agha, Mickey, Lovich, J.E., Ennen, J.R., Augustine, Benjamin, Arundel, T.R., Murphy, M.O., Meyer-Wilkins, Kathie, Bjurlin, Curtis, Delaney, David, Briggs, Jessica, Austin, Meaghan, Madrak, S.V., and Price, S.J., 2015, Turbines and terrestrial vertebrates - Variation in tortoise survivorship between a wind energy facility and an adjacent undisturbed wildland area in the desert Southwest (U.S.A.): Environmental Management, v. 56, no. 2, p. 332-341, https://doi.org/10.1007/s00267-015-0498-9.

Lovich, J.E., Agha, Mickey, Yackulic, C.B., Meyer-Wilkins, Kathie, Bjurlin, Curtis, Ennen, J.R., Arundel, T.R., and Austin, Meaghan, 2014, Nest site characteristics, nesting movements, and lack of long-term nest site fidelity in Agassiz's desert tortoises at a wind energy facility in southern California: California Fish and Game, v. 100, no. 3, p. 404-416.

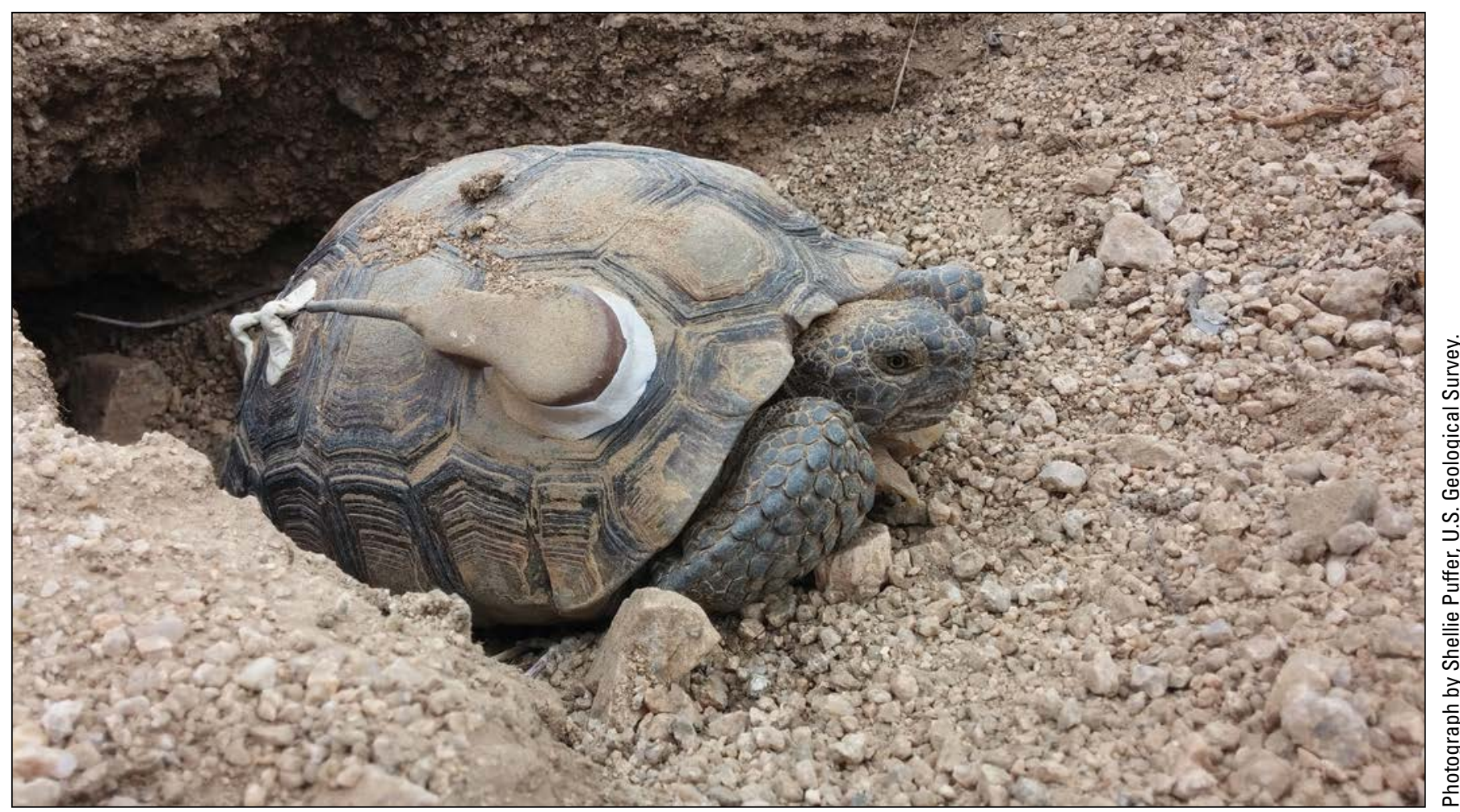

A female Agassiz's desert tortoise, wearing a USGS radio, lounges in the entrance of her burrow at Joshua Tree National Park. 


\section{Pollinators}

\section{Impact of Biofuel Crop Production on Pollinators in the Northern Great Plains}

The USGS, in cooperation with the U.S. Department of Agriculture (USDA), is quantifying how recent reductions in USDA conservation program enrollments affect pollinator habitat. Scientists are also developing a risk assessment model to identify what portions of the Northern Great Plains have undergone the most substantial land-use changes due to biofuel crop development while also supporting the highest density of commercial beekeepers. This study addresses several of the key information needs to better understand, minimize, and recover from pollinator losses.

\section{Contact}

Clint Otto, USGS Northern Prairie Wildlife Research Center, cotto@usgs.gov, (701) 253-5563

\section{Publications}

Spivak, Marla, Browning, Zac, Goblirsch, Mike, Lee, Katie, Otto, Clint, Smart, Matthew, and Wu-Smart, Judy, 2017, Why does bee health matter? The science surrounding honey bee health concerns and what we can do about it: The Council of Agricultural Science and Technology, cast commentary, https://www.cast-science.org/file.cfm/media/ products/digitalproducts/QTA20171_Bee_Health_ 565CB839D149E.pdf.

Otto, C.R., Roth, C.L., Carlson, B.L., and Smart, M.D., 2016, Land-use change reduces habitat suitability for supporting managed honey bee colonies in the Northern Great Plains: Proceedings of the National Academy of Sciences, v. 113, p. 10430-10435, https://doi.org/10.1073/pnas.1603481113.

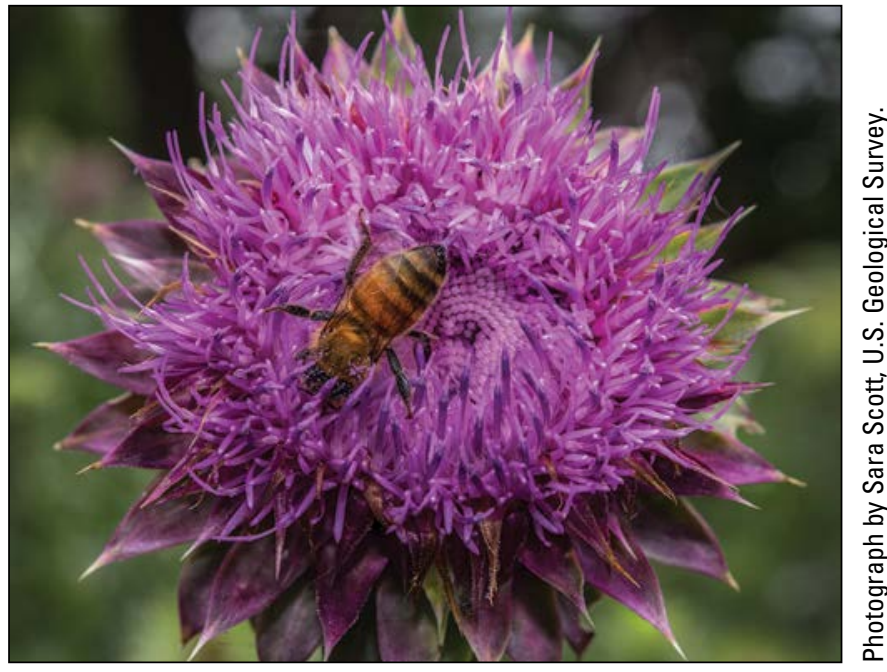

Bee and musk thistle.

U.S. Geological Survey, 2016, USGS pollinator research and monitoring [Kirk Mason, producer; Clint Otto, videographer]: U.S. Geological Survey, 5.02 min., https://www.youtube.com/watch?v=3_O6RDdrfDc.

\section{Taxonomic Characterization of Honey Bee Pollen Foraging}

USGS scientists recently developed a genetic sequencing technique to identify pollen collected by foraging bees. The USGS is currently applying this technique to understand how land-use change and biofuel crop development affect forage for pollinators in agroecosystems. Together, this information can be used to evaluate specific plants that can be used in restoration programs for pollinators.

\section{Contact}

Clint Otto, USGS Northern Prairie

Wildlife Research Center, cotto@usgs.gov, (701) 253-5563

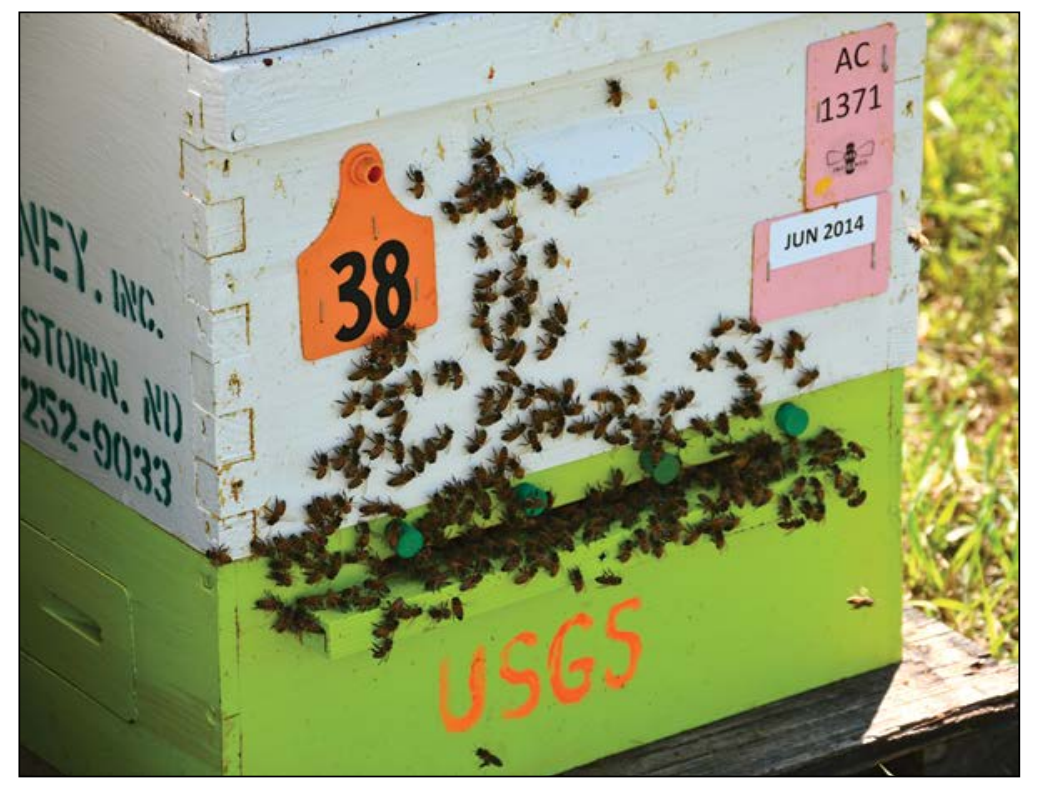

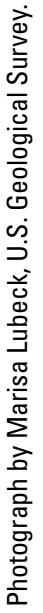

USGS Northern Prairie Wildlife Research Center partners with professional beekeepers in North Dakota to evaluate what plant species honey bees forage and when. 


\section{Publications}

Smart, M.D., Cornman, R.S., Iwanowicz, D.D., McDermott-Kubeczko, M., Pettis, J.S., Spivak, M.S., and Otto, C.R.V., 2017, A comparison of honey bee-collected pollen from working agricultural lands using light microscopy and ITS metabarcoding: Environmental Entomology, v. 46, no. 1, p. 38-49, https://doi.org/10.1093/ee/nvw159.

Cornman, R.S., Otto, C.R.V., Iwanowicz, Deborah, and Pettis, J.S., 2015, Taxonomic characterization of honey bee (Apis mellifera) pollen foraging based on non-overlapping paired-end sequencing of nuclear ribosomal loci: PLOS ONE, v. 10, no. 12, e0145365, https://doi.org/10.1371/journal.pone.0145365.

\section{Designing Conservation Seeding Mixes}

USGS scientists are working closely with the USDA to quantify the benefits of USDA conservation lands for supporting healthy pollinator populations in the Northern Great Plains. In response to this need, the USGS developed the Pollinator Library (https://www.npwrc.usgs.gov/pollinator/), a tool for land managers to assist with conservation seeding mix design for land enhancement programs. This tool may be useful for restoring habitat for pollinators in areas where marginally productive lands are retired from biofuel crop production.

\section{Contact}

Clint Otto, USGS Northern Prairie Wildlife Research Center, cotto@usgs.gov, (701) 253-5563

\section{Publications}

Iovanna, R., Ando, A., Swinton, S., Hellerstein, D., Kagan, J., Mushet, D., and Otto, C.R.V., 2017, Assessing pollinator habitat services to optimize conservation programs, chap. 1 of The Council on Food, Agricultural and Resource Economics (C-FARE) Report: Washington, D.C., C-FARE, report no. 0114-301b, 28 p., http://www.cfare.org/UserFiles/file/ Chapter1-AssessingPollinatorHabitatServicestoOptimizeConservationPrograms_v2.pdf.

Otto, C.R.V., O’Dell, S., Bryant, R.B., Euliss, N.H., Jr., Bush, R., and Smart, M.D., 2017, Using publicly available data to quantify plant-pollinator interactions and evaluate conservation seeding mixes in the Northern Great Plains: Environmental Entomology, v. 46, no. 3, p. 565-578, https://doi.org/10.1093/ee/nvx070. 


\section{Fish and Other Aquatic Species}

\section{Understand Risks}

\section{ILI6. Hydropower Effects on River Food Webs}

A majority of river systems in the Western United States have been altered by the construction of hydroelectric dams that have created impoundments upstream and greatly altered the natural flow patterns downstream. USGS scientists developed a life history-hydrodynamic model to look at the effects of downstream regulated flow regimes on aquatic insect populations. Aquatic insects are a cornerstone of river food webs and can be a key indicator to the effects of altered flow regimes on the larger ecological river system. Modeled results show that flow regimes favoring hydroelectric-power generation create a scenario where many aquatic insects could be eliminated from downstream habitats.

\section{Contact}

Theodore Kennedy, USGS Southwest Biological Science Center, tkennedy@usgs.gov, (928) 556-7374

\section{Publication}

Kennedy, T.A., Muehlbauer, J.D., Yackulic, C.B., Lytle, D.A., Miller, S.W., Dibble, K.L., Kortenhoven, E.W., Metcalfe, A.N., and Baxter, C.V., 2016, Flow management for hydropower extirpates aquatic insects, undermining river food webs: BioScience, v. 66, no. 7, p. 561-575, https://doi.org/10.1093/biosci/biw059.

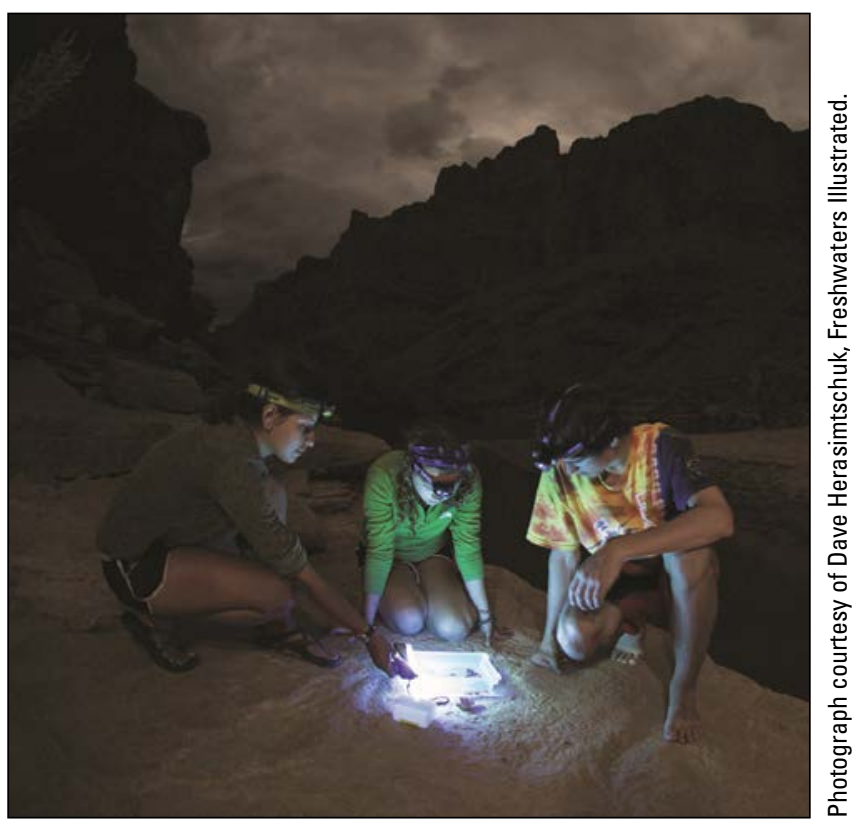

Participants in a Grand Canyon Youth river trip deploy light traps along the banks of the Colorado River in the Grand Canyon (from Kennedy and others, 2016).

\section{Vulnerability of Brook Trout Streams to Shale Gas Development in the Upper Susquehanna River Basin}

The Upper Susquehanna River Basin drains portions of Pennsylvania and New York, and includes many high-quality and native brook trout streams. USGS and West Virginia University scientists are using spatial modeling approaches to assess the potential cumulative effects of unconventional oil and gas (UOG) development on high-quality brook trout streams in the Pennsylvania portion of the basin, which has experienced relatively recent, rapid increase in UOG development. Vulnerability models were developed that incorporate all stages of the UOG development process - infrastructure, drilling, spills, and water withdrawals - that may affect fish and other aquatic resources. These models incorporate measures of aquatic health and status to identify streams that are vulnerable to UOG development. This vulnerability framework can be applied to a variety of ecosystems or energy development scenarios.

\section{Contact}

Kelly O. Maloney, USGS Leetown Science Center, kmaloney@usgs.gov, (304) 724-4579 


\section{Publications}

Maloney, K.O., Young, J.A., Faulkner, S.P., Hailegiorgis, Atesmachew, Slonecker, E.T., and Milheim, L.E., 2018, A detailed risk assessment of shale gas development on headwater streams in the Pennsylvania portion of the Upper Susquehanna River Basin, U.S.A.: Science of the Total Environment, v. 610-611, p. 154-166, https://doi.org/10.1016/j.scitotenv.2017.07.247.

Maloney, K.O., Baruch-Mordo, Sharon, Patterson, L.A., Nicot, J.-P., Entrekin, S.A., Fargione, J.E., Kiesecker, J.E., Konschnik, K.E., Ryan, J.N., Trainor, A.M., Saiers, J.E., and Wiseman, H.J., 2017, Unconventional oil and gas spills-Materials, volumes and risks to surface waters in four States of the U.S.: Science of the Total Environment, v. 581-582, p. 369-377, https://doi.org/10.1016/j.scitotenv.2016.12.142.

Patterson, L.A., Konschnik, K.E., Wiseman, Hannah, Fargione, Joseph, Maloney, K.O., Kiesecker, Joseph, Nicot, J.-P., BaruchMordo, Sharon, Entrekin, Sally, Trainor, Anne, Ryan, J.N., and Saiers, J.E., 2017, Unconventional oil and gas spills-Risks, mitigation priorities and State reporting requirements: Environmental Science and Technology, v. 51, no. 5, p. 2563-2573, https://doi.org/10.1021/acs.est.6b05749.

Entrekin, S.A., Maloney, K.O., Kapo, K.E., Walters, A.W., Evans-White, M.A., and Klemow. K.M., 2015, Stream vulnerability to widespread and emergent stressors-A focus on unconventional oil and gas: PLOS ONE, v. 10, no. 9, e0137416, https://doi.org/10.1371/journal.pone.0137416.

Brittingham, M.C., Maloney, K.O., Farag, A.M., Harper, D.D., and Bowen, Z.H., 2014, Ecological risks of shale oil and gas development to wildlife, aquatic resources and their habitats: Environmental Science and Technology, v. 48, no. 19, p. 11034-11047, https://doi.org/10.1021/es5020482.

Maloney, K.O., and Yoxtheimer, D.A., 2012, Production and disposal of waste materials from gas and oil extraction from the Marcellus Shale Play in Pennsylvania: Environmental Practice, v. 14, no. 4, p. 278-287, https://doi.org/10.1017/ s146604661200035x.

Smith, D.R., Snyder, C.D., Hitt, N.P., Young, J.A., and Faulkner, S.P., 2012, Shale gas development and brook troutScaling best management practices to anticipate cumulative effects: Environmental Practice, v. 14, no. 4, p. 366-381, https://doi.org/10.1017/s1466046612000397.

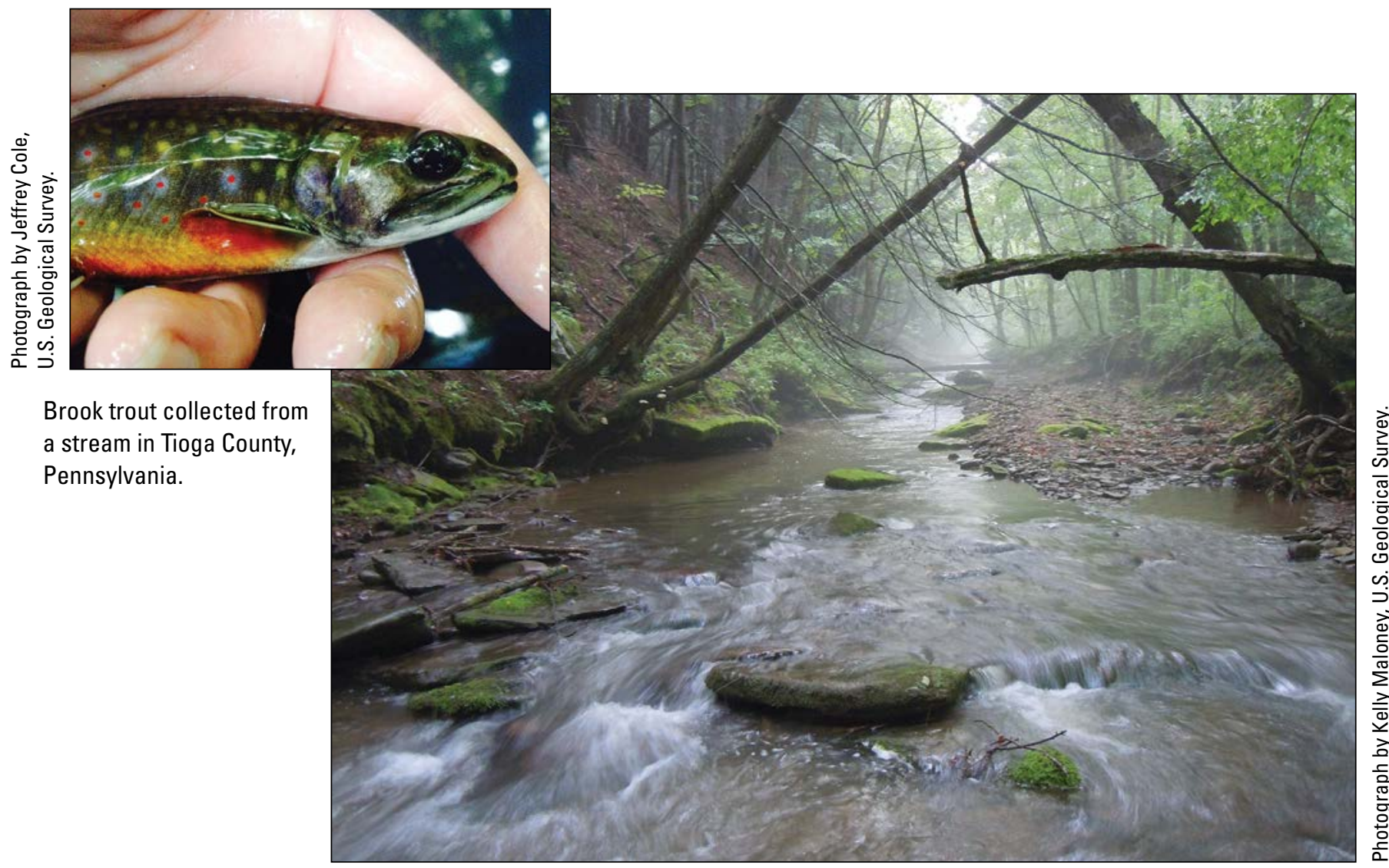

A brook trout stream during stormflow in Tioga County, Pennsylvania. 


\section{Legacy Brine Contamination From Oil Production Effects on Amphibian Survival}

Historical oil production practices often released saline co-produced waters (brines) affecting wetland water quality directly or persisting in sediments in the Prairie Pothole wetlands in Montana and North Dakota. USGS scientists are using a combination of laboratory experiments and field surveys to (1) assess variation in survival of larval amphibians; (2) determine effects of brine contamination on amphibian distribution and abundance; (3) characterize microbial community structures in wetland sediments, water, and on amphibian skin (microbiome); and (4) measure persistence of contaminants (metals) in wetland sediments and amphibian tissues. Combined with other information on ecological community structure and function, the study results could help inform future practices for brine disposal and provide meaningful targets for habitat restoration.

\section{Contacts}

Chauncey Anderson, USGS Oregon Water Science Center, chauncey@usgs.gov, (503)251-3206

Blake Hossack, USGS Northern Rocky Mountain Science Center, blake_hossack@usgs.gov, (406) 542-3245

\section{Publication}

Hossack, B.R., Puglis, H.J., Battaglin, W.A., Anderson, C.W., Honeycutt, R.K., and Smalling, K.L., 2017, Widespread legacy

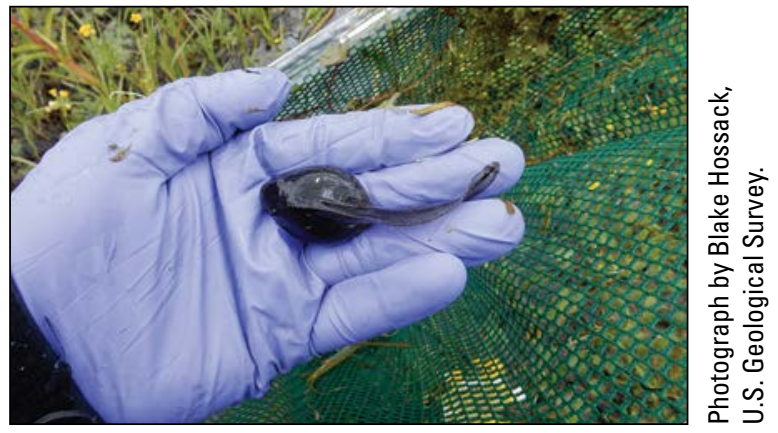

Northern leopard frog tadpole collected from a pond in North Dakota. brine contamination from oil production reduces survival of chorus frog larvae: Environmental Pollution, v. 231, Part 1, p. 742-751, https://doi.org/10.1016/j.envpol.2017.08.070.

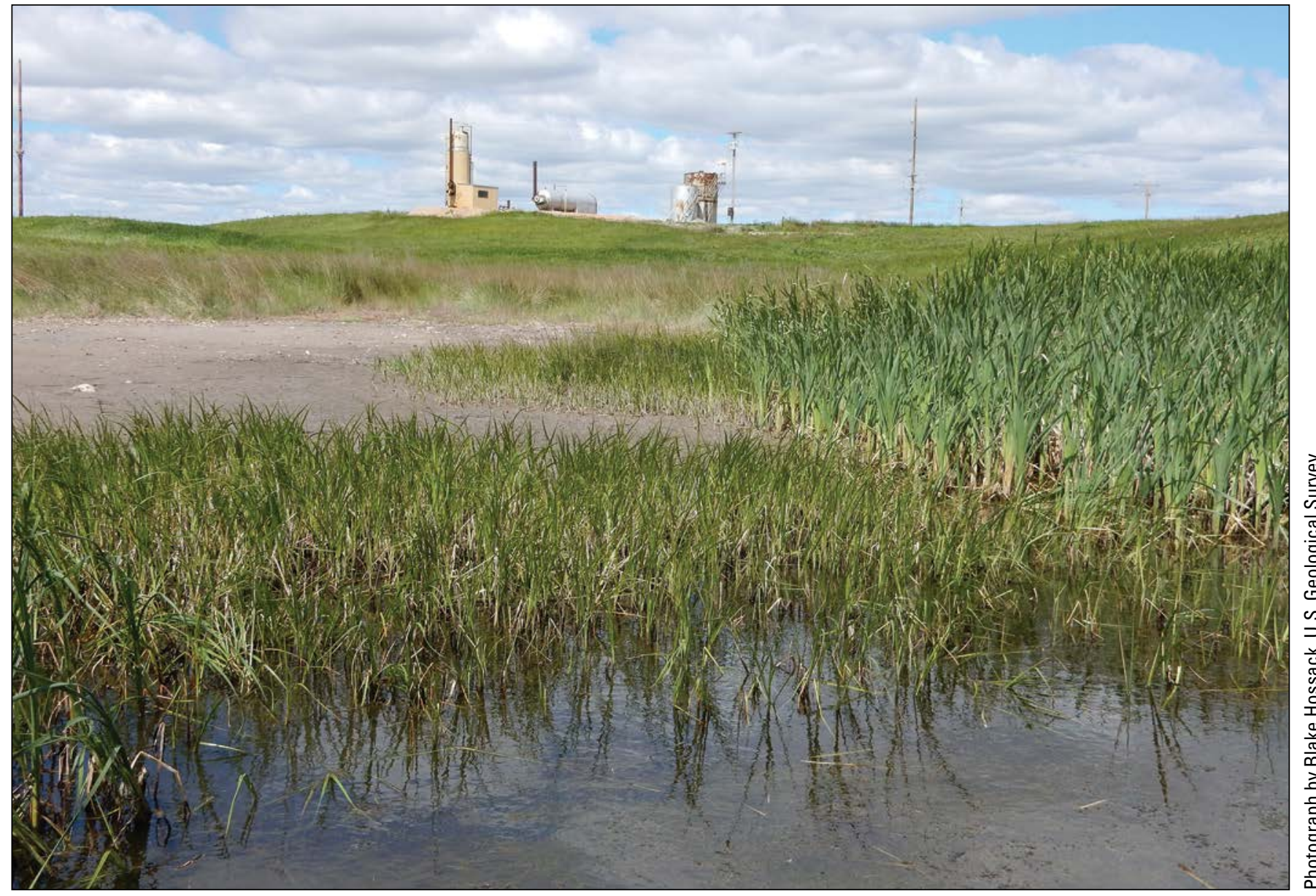




\section{Measure Impacts}

\section{LIA. Effects of Dam Operations on Tailwater Fisheries}

Nonnative rainbow trout were introduced to the Colorado River downstream from Glen Canyon Dam in 1964 shortly after the dam was completed. The objective of this and other nonnative fish introductions was to create recreational sport fisheries. Dam operations can affect the growth, survival, and distribution of this important sportfish. USGS scientists conducted a large-scale mark-recapture study to determine the cause for long-term trends in rainbow trout growth and abundance as well as the effects of normal operations and experimental floods on downstream movement. High and steady flows resulted in large levels of recruitment while movement rates were low and unaffected by flows including experimental floods.

\section{Contact}

Mike Yard, USGS Southwest Biological Science Center, myard@usgs.gov, (928) 556-7377

\section{Publications}

Korman, Josh, Yard, M.D., and Kennedy, T.A., 2017, Trends in rainbow trout recruitment, abundance, survival, and growth during a boom-and-bust cycle in a tailwater fishery: Transactions of the American Fisheries Society, 53 p., https://doi.org/10.1080/00028487.2017.1317663.

Yard, M.D., Korman, Josh, Walters, C.J., and Kennedy, T.A., 2015, Seasonal and spatial patterns of growth of rainbow trout in the Colorado River in Grand Canyon, Arizona: Canadian Journal of Fisheries and Aquatic Sciences, v. 73, no. 1, p. 125-139, https://doi.org/10.1139/cjfas-2015-0102.

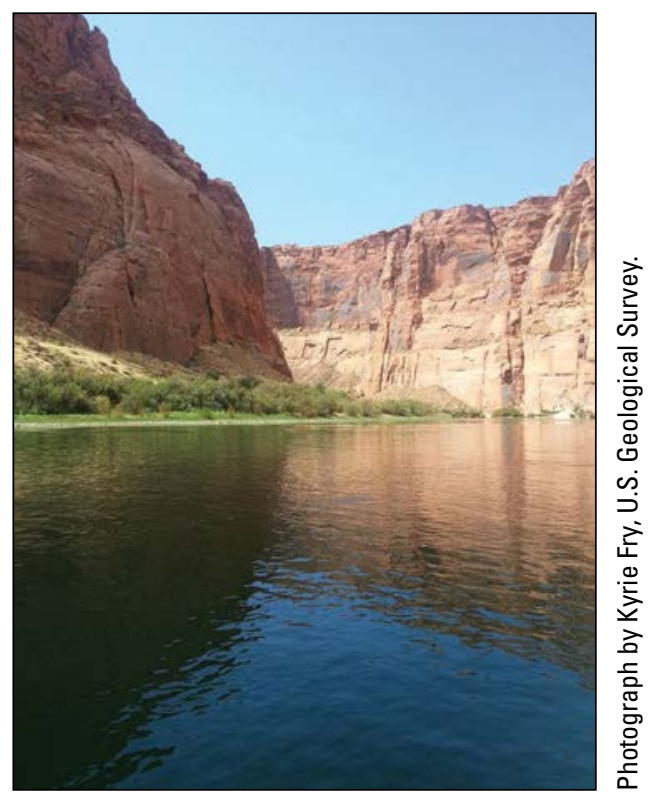

Colorado River downstream from the Glen Canyon Dam.

\section{Effects of Dam Operations on Endangered Fishes}

Glen Canyon Dam operations affect downstream environmental conditions of the Colorado River in Glen and Grand Canyons which, in turn, can affect resident aquatic species like fish. USGS scientists assessed the effects of temperature, turbidity (murkiness), food availability, flow variability, and nonnative fish abundance on endangered humpback chub. Growth models showed that environmental conditions like temperature and duration of turbidity best described growth in subadult humpback chub. Understanding the relative importance of various environmental factors on humpback chub allows managers to make informed decisions regarding the operation of Glen Canyon Dam and management actions intended to facilitate the recovery of this endangered species.

\section{Contact}

Charles Yackulic, USGS Southwest Biological Science Center, cyackulic@usgs.gov, (928) 556-7379

\section{Publication}

Dzul, M.C., Yackulic, C.B., Korman, Josh, Yard, M.D., and Muehlbauer, J.D., 2016, Incorporating temporal heterogeneity in environmental conditions into a somatic growth model: Canadian Journal of Fisheries and Aquatic Sciences, v. 74, no. 3, p. 316-326, https://doi.org/10.1139/cjfas-2016-0056.

\footnotetext{
ILII. Fish Passage and Survival Through Diversion Dams

Diversion dams can negatively affect emigrating juvenile salmon populations because fish must pass through the impounded river created by the dam, negotiate a passage route at the dam, and emigrate through a riverine reach that has been affected by reduced river discharge. To quantify the effects of a main-stem diversion dam on juvenile Chinook salmon, USGS scientists used radio telemetry to understand how dam operations and river discharge downstream from the dam affected routespecific passage and survival.
} 


\section{Contact}

Russell Perry, USGS Western Fisheries Research Center, rperry@usgs.gov, (509) 538-2299

\section{Publications}

Courter, I.I., Garrison, T.M., Kock, T.J., Perry, R.W., Child, D.B., and Hubble, J.D., 2016, Benefits of prescribed flows for salmon smolt survival enhancement vary longitudinally in a highly managed river system: River Research and Applications, v. 32, no. 10, p. 1999-2008, https://doi.org/10.1002/rra.3066.

Perry, R.W., Kock, T.J., Courter, T.M., Garrison, T.M., Hubble, J.D., and Child, D.B., 2016, Dam operations affect route-specific passage and survival of juvenile Chinook salmon at a main-stem diversion dam: River Research and Applications, v. 32, no. 10, p. 2009-2019, https://doi.org/10.1002/rra.3059.

Romine, J.G., Perry, R.W., Pope, A.C., Stumpner Paul, Liedtke, T.L., Kumagai, K.K., and Reeves, R.L., 2016, Evaluation of a floating fish guidance structure at a hydrodynamically complex river junction in the Sacramento-San Joaquin River Delta, California, U.S.A.: Marine and Freshwater Research, v. 68, no. 5, p. 878-888, https://doi.org/10.1071/MF15285.

\section{Toxicity Associated With Produced Waters From Oil and Gas Activity in the Bakken Region}

A significant spill related to oil and gas activity was reported on Blacktail Creek, Williams County, North Dakota, in late 2014. The USGS investigated potential effects on aquatic resources related to this spill by conducting in situ bioassays with newly hatched fathead minnows on Blacktail Creek in 2015 and 2016. Significant mortality was observed in 2015, but not during 2016. A laboratory toxicity test with reconstituted water mimicking the water quality in the contaminated site water indicated that elevated major ions in the contaminated surface water were toxic to fish and invertebrates. The USGS is also examining the effects of historic brine contamination related to oil and gas activity with waters collected from the Goose Lake National Wildlife Refuge in Montana. The effects of site waters on the growth of duckweed are being investigated as part of this study. Results can provide insight into the effects of oil brines on aquatic plants, an important rearing area for migratory waterfowl.

\section{Contacts}

Isabelle Cozzarelli, USGS National Research Program, icozzare@usgs.gov, (703)648-5899

Aïda Farag, USGS Columbia Environmental Research Center, aida_farag@usgs.gov, (307) 733-2314

\section{Publication}

Cozzarelli, I.M., Skalak, K.J., Kent, D.B., Engle, M.A., Benthem, A., Mumford, A.C., Haase, K., Farag, A., Harper, D., Nagel, S.C., Iwanowicz, L.R., Orem, W.H., Akob, D.M., Jaeschke, J.B., Galloway, J., Kohler, M., Stoliker, D.L., and Jolly, G.D., 2017, Environmental signatures and effects of an oil and gas wastewater spill in the Williston Basin, North Dakota: Science of the Total Environment, v. 579, p. 1781-1793, https://doi.org/10.1016/ j.scitotenv.2016.11.157.

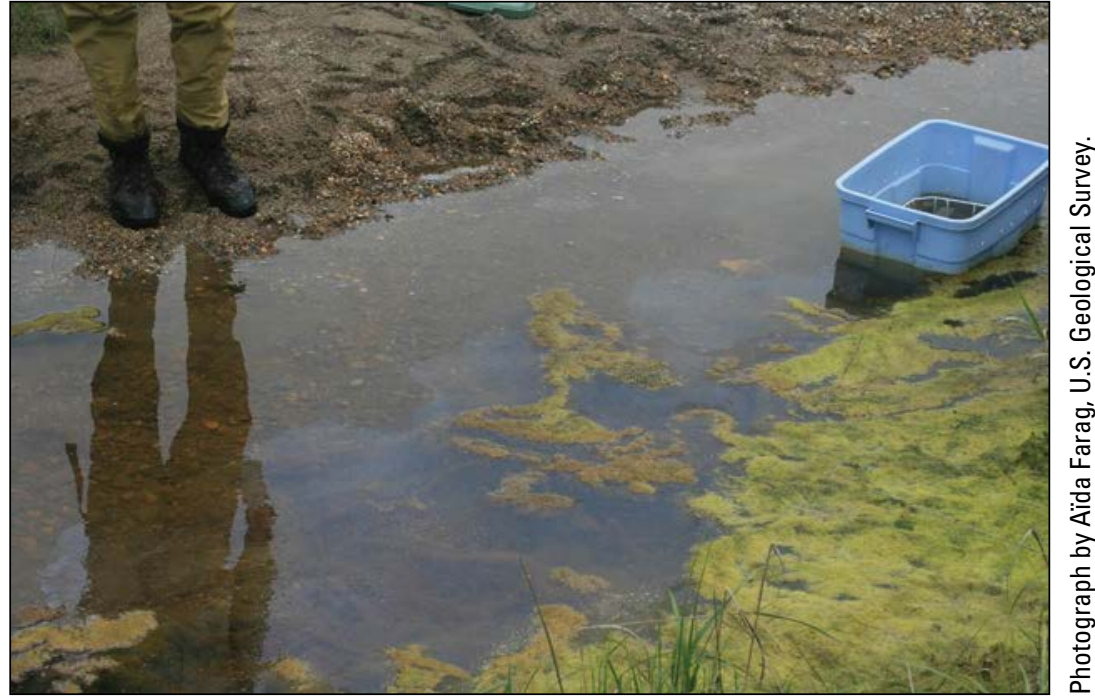

Site of toxicity documented on Blacktail Creek, North Dakota, in 2016. 


\section{Inform Solutions}

\section{(21) 83. Behavioral Studies of Fish Routed Around a Hydroelectric Dam in the North Fork Reservoir}

USGS scientists used acoustic cameras to assess the behavior and abundance of bull trout-size fish at the entrance to the North Fork Reservoir juvenile fish floating surface collector (FSC). The purpose of the FSC is to collect downriver migrating juvenile salmonids at the North Fork Dam and safely route them around the hydroelectric projects. The objective of the acoustic camera component of this study was to assess the behaviors of bull trout-size fish observed near the FSC and to determine if the presence of bull trout-size fish influenced the collection or abundance of juvenile salmonids.

\section{Contact}

Noah Adams, USGS Western Fisheries Research Center, nadams@usgs.gov, (509) 538-2964

\section{Publication}

Adams, N.S., and Smith, C.D., 2017, Spatial and temporal distribution of bull trout (Salvelinus confluentus)-size fish near the floating surface collector in the North Fork Reservoir, Oregon, 2016: U.S. Geological Survey Open-File Report 2017-1080, 27 p., https://doi.org/10.3133/ofr20171080.

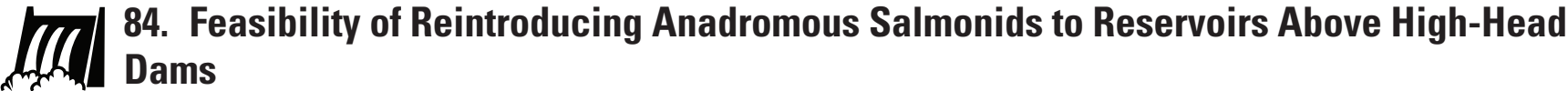

Reintroductions of anadromous salmonids above formerly impassable hydroelectric dams are being proposed to mitigate the loss of access to habitat and fish production due to blocked upstream passage. The USGS evaluated the carrying capacity in three hydropower reservoirs on the Lewis River in Washington to determine if they can support reintroduced populations of juvenile spring Chinook salmon and other salmonids by analyzing consumption demand and seasonal food availability. In addition, scientists evaluated the potential predation mortality to juvenile anadromous salmonids. These studies highlight the importance of quantitatively evaluating trophic interactions within reservoirs slated for reintroduction, because they serve both as functional migration corridors and offer profitable juvenile-rearing habitats despite hosting abundant predator populations. This information benefits fisheries managers and power operators by determining the net production potential of habitats proposed for reintroduction of fish species before major investments are committed. Moreover, this approach can identify options for design and operations of hydropower facilities that could satisfy power demand while minimizing impacts to aquatic resources.

\section{Contact}

David Beauchamp, USGS, Western Fisheries Research Center, fadave@usgs.gov, (206) 526-6596

\section{Publications}

Sorel, M.H., Hansen, A.G., Connelly, K.A., and Beauchamp D.A., 2016, Trophic feasibility of reintroducing anadromous salmonids in three reservoirs on the North Fork Lewis River, Washington-Prey supply and consumption demand of resident fishes: Transactions of the American Fisheries Society, v. 145, no. 6, p. 1331-1347, https://doi.org/10.1080/00028487.2016.1219678.

Sorel, M.H., Hansen, A.G., Connelly, K.A., Wilson, A.C., Lowery, E.D., and Beauchamp, D.A., 2016, Predation by northern pikeminnow and tiger muskellunge on juvenile salmonids in a high-head reservoir-Implications for anadromous fish reintroductions: Transactions of the American Fisheries Society, v. 145, no. 3, p. 521-536, https://doi.org/10.1080/00028487.2015.1131746. 


\section{Informing Fish Passage Decisions at the Yale and Merwin Projects on the Lewis River}

Fragmentation has been identified as one of the major factors limiting salmon populations; however, stream networks above hydropower facilities often represent suitable habitat for reintroductions, particularly in the context of habitat integrity and reaches with suitable thermal regimes. As such, numerous hydropower facilities continue to plan strategies to move salmon around hydropower facilities in the absence of volitional passage. Salmon reintroductions, however, represent a substantial resource commitment, and identifying the means to maximize the effectiveness and sustainability of salmon reintroductions is critical. Here, we conducted a suite of behavioral, habitat, demographic, and community-interaction studies to evaluate the potential risks and benefits of anadromous reintroductions in the Lewis River, Washington. In addition, we considered the risks to extant native populations of salmonids such as bull trout, which are currently listed under the ESA.

\section{Contact}

Robert Al-Chokhachy, Northern Rocky Mountain Science Center, ral-chokhachy@usgs.gov, (406) 994-7842

\section{Publication}

Al-Chokhachy, Robert, Clark, Christopher, Sorel, Mark, and Beauchamp, David, 2015, Development of new information to inform fish passage decisions at the Yale and Merwin Projects on the Lewis River: Bozeman, Mont., U.S. Geological Survey Northern Rocky Mountain Science Center, 333 p., http://www.pacificorp.com/content/dam/pacificorp/doc/Energy_Sources/ Hydro/Hydro_Licensing/Lewis_River/li/acc/LR_New_Inform_Progress_Report_August_2015.pdf.

\section{Structured Decision Making for the Management of Glen Canyon Dam}

The USGS, in cooperation with the U.S. Bureau of Reclamation (BOR), NPS, and Argonne National Laboratory, provided an analysis of the long-term management of water releases from Glen Canyon Dam in northern Arizona and associated management activities. Two primary decision analysis methods - multicriteria decision analysis and the expected value of information - were used to evaluate resource goals and the influence of uncertainty by the various alternative plans. This information was used by the BOR and NPS in their evaluation of management alternatives for the Glen Canyon Dam Environmental Impact Statement, and the decision analysis was included as an Appendix to the Environmental Impact Statement. In December 2016, the Secretary of the Interior signed a Record of Decision, choosing a 20-year management plan for Glen Canyon Dam.

\section{Contact}

Michael Runge, USGS Patuxent Wildlife Research Center, mrunge@usgs.gov, (301) 497-5748

\section{Publication}

Runge, M.C., LaGory, K.E., Russell, Kendra, Balsom, J.R., Butler, R.A., Coggins, L.G., Jr., Grantz, K.A., Hayse, John, Hlohowskyj, Ihor, Korman, Josh, May, J.E., O’Rourke, D.J., Poch, L.A., Prairie, J.R., VanKuiken, J.C., Van Lonkhuyzen, R.A., Varyu, D.R., Verhaaren, B.T., Vesekla, T.D., Williams, N.T., Wuthrich, K.K., Yackulic, C.B., Billerbeck, R.P., and Knowles, G.W., 2015, Decision analysis to support development of the Glen Canyon Dam Long-Term Experimental and Management Plan: U.S. Geological Survey Scientific Investigations Report 2015-5176, 64 p., https://doi.org/10.3133/ $\operatorname{sir} 20155176$.

\footnotetext{
tal 87. Full-Scale Development and Evaluations of Fish Passage Structures and Fish Behavior

Many migratory fish species have been in decline worldwide due in large part to dams and poorly designed fishways that prevent fish from reaching spawning and feeding grounds. The USGS S.O. Conte Anadromous Fish Research Center laboratory's unique large-scale flume facility enables scientists and engineers to design and test full-scale upstream- and downstream passage structures under semicontrolled conditions with actively migrating test species. Working in collaboration with the USFWS, the NMFS, the U.S. Department of Energy (DOE), and State agencies, the USGS is improving and developing new fish passage designs and technologies, and also identifying behaviors and hydraulics that inform design criteria for successful passage. The goal of this work is to restore self-sustaining populations of migratory fish while maintaining a balance between energy production, water management, and ecosystem restoration.
}

\section{Contacts}

Theodore Castro-Santos, USGS Leetown Science Center, tcastrosantos@usgs.gov, (413) 863-3838

Alex Haro, USGS Leetown Science Center, aharo@usgs.gov, (413) 863-3806 


\section{Publications}

Miehls, S.M., Johnson, N.S., and Haro, Alex, 2017, Electrical guidance efficiency of downstream migrating juvenile sea lamprey decreases with increasing water velocity: Transactions of the American Fisheries Society, v. 146, no. 2, p. 299-307, https://doi.org/10.1080/00028487.2016.1256834.

Mulligan, K.B., Towler, Brett, Haro, Alex, and Ahlfeld, D.P., 2017, A computational fluid dynamics modeling study of guide walls for downstream fish passage: Ecological Engineering, v. 99, p. 324-332, https://doi.org/10.1016/j.ecoleng.2016.11.025.

Haro, Alex, Watten, Barnaby, and Noreika, John, 2016, Passage of downstream migrant American eels through an airlift deep bypass system: Ecological Engineering, v. 91, v. 545-552, https://doi.org/10.1016/j.ecoleng.2016.02.028.

Castro-Santos, Theodore, and Haro, Alex, 2013, Survival and behavioral effects of exposure to a hydrokinetic turbine on juvenile Atlantic salmon and adult American shad: Estuaries and Coasts, v. 38, no. S1, https://doi.org/10.1007/s12237-013-9680-6.

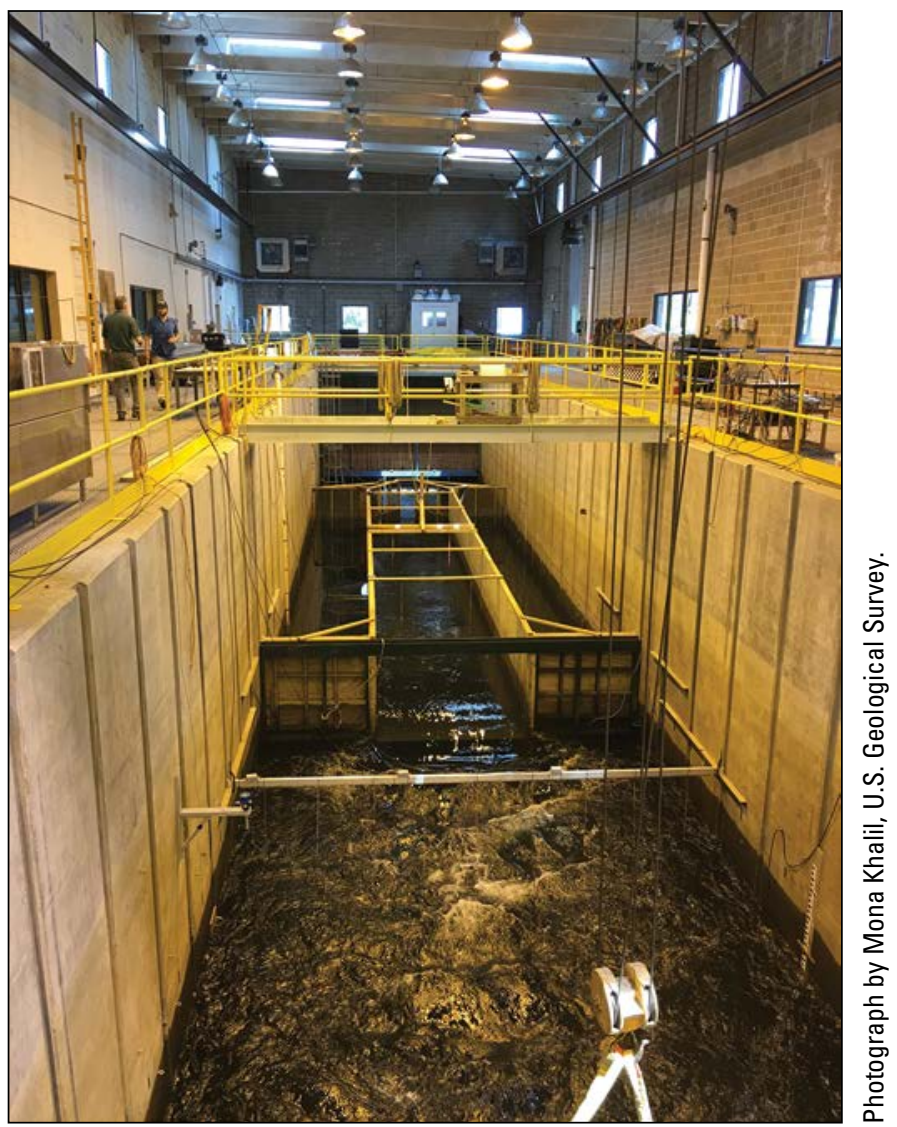

Large-scale flume facility at the USGS S.0. Conte Anadromous Fish Research Center in Turner Falls, Massachusetts.

\section{88. Biotelemetry Studies of Fish Behavior and Passage Through Dams}

Understanding and quantifying fish behavior is essential for understanding fish passage problems and developing effective passage solutions across hydropower dams and other manmade barriers. Biotelemetry (radio and acoustic telemetry) has emerged as the method of choice for acquiring detailed, individual-based data for quantifying passage and underlying criti-

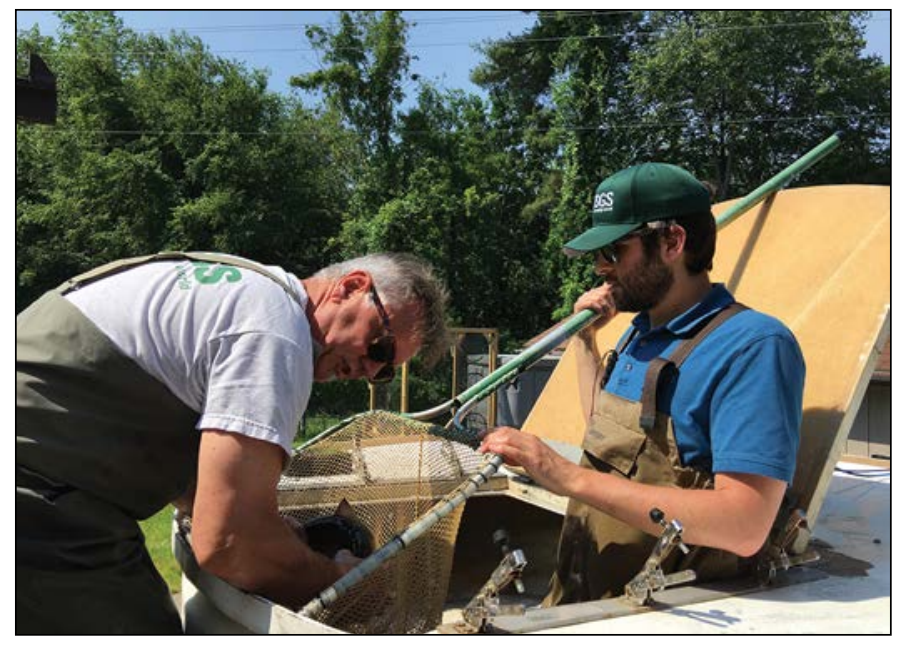

Scientists remove American shad from a transport tank and tag each fish with a transmitter device to test their movement behavior in the flume facility. cal fish behaviors. Working in collaboration with the USFWS, the NMFS, the DOE, and State agencies, the USGS S.O. Conte Anadromous Fish Research Center laboratory has adapted and developed advanced telemetry technologies for studies of fish passage and developed advanced statistical methods for data analysis to expand the toolbox of available telemetry techniques used for fish passage evaluations. These advances maximize the return on these labor- and cost-intensive studies to improve efficiencies in integrating fish behavior with the hydraulic and physical characteristics of passage structures, thus improving passage design.

\section{Contacts}

Theodore Castro-Santos, USGS Leetown Science Center, tcastrosantos@usgs.gov, (413) 863-3838

Alex Haro, USGS Leetown Science Center, aharo@usgs. gov, (413) 863-3806 


\section{Publications}

Harbicht, A.B., Castro-Santos, Theodore, Ardren, W.R., and Fraser, D.J., 2017, Novel, continuous monitoring of fine-scale movement using fixed-position radiotelemetry arrays and random forest location fingerprinting: Methods in Ecology and Evolution, v. 8, no. 7, p. 850-859, https://doi.org/10.1111/2041-210X.12745.

Theim, J.D., Dawson, J.W., Gleiss, A.C., Martins, E.G., Haro, A., Castro-Santos, T., Danylchuk, A.J., Wilson, R.P., and Cooke, S.J., 2015, Accelerometer-derived activity correlates with volitional swimming speed in lake sturgeon (Acipenser fluvescens): Canadian Journal of Zoology, v. 93, no. 8, p. 645-654, https://doi.org/10.1139/cjz-2014-0271.

\section{Risks and Benefits of Actively Managing a Small Bull Trout Population}

Habitat fragmentation is one of the major factors contributing to the declines in distribution and abundance of many native salmonid species, including bull trout. Increasingly, managers are considering options to maintain and enhance the persistence of isolated local populations of bull trout through active management strategies. Understanding the ecological costs and benefits of such actions is a necessary step to achieve conservation goals. Here we used an individual-based model to evaluate populationlevel risks and benefits of an ongoing management program aimed at mitigating the anthropogenic fragmentation of the lower Clark Fork River in Montana due to hydropower facilities.

\section{Contact}

Robert Al-Chokhachy, Northern Rocky Mountain Science Center, ral-chokhachy@usgs.gov, (406) 994-7842

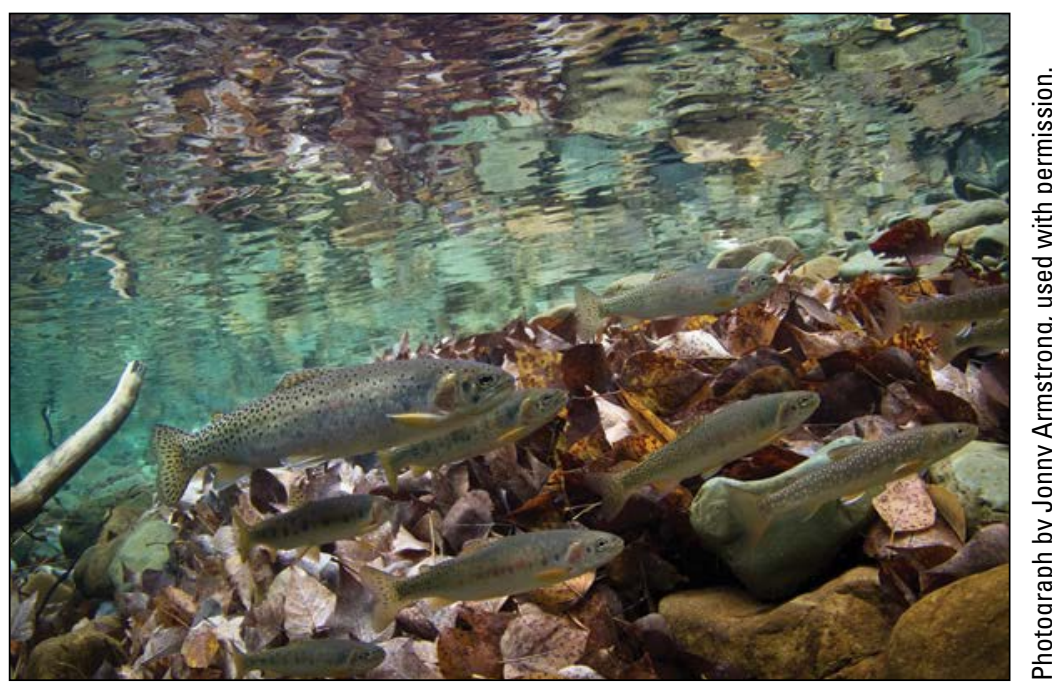

Native Westslope cutthroat trout and bull trout swim in the cool waters of the Flathead River near Glacier National Park, Montana.

\section{Publication}

Al-Chokhachy, Robert, Moran, Sean, Bernall, Shana, Fredenberg, Wade, and DosSantos, J.M., 2015, Risks and benefits of actively managing a small bull trout population in a fragmented landscape: Transactions of the American Fisheries Society, v. 144, no. 3, p. 515-531, https://doi.org/10.1080/00028487.2015.1007162. 


\section{Optimizing Hydropower Operations to Reduce Eel Mortality and Turbine Shutdown}

Hydroelectric dams are one of the contributing causes of freshwater eel declines by causing migratory delays and turbine mortality. An inherent tradeoff underlies turbine management where the competing demand for more hydropower comes at the expense of eel survival. A win-win solution exists when an option performs better on all competing demands compared to other options. Scientists with the USGS, USFWS, and North Carolina State University created a predictive model for silver American eels migration based on a recent telemetry study to develop decision rules for turbine management in the Shenandoah River system. The performance of alternative decision rules was compared to the status quo policy to search for win-win solutions. A range of cutoff probabilities resulted in a win-win situation with both reduced eel mortality and increased turbine operation relative to the current shutdown strategy. Monitoring of the implementation is needed to evaluate and update the predictive model and to refine the decision rule. Although the decision is framed for the Shenandoah River system, the analytical approach could be used to develop decision rules for turbine shutdown policy in other areas.

\section{Contact}

David Smith, USGS Leetown Science Center, drsmith@usgs.gov,

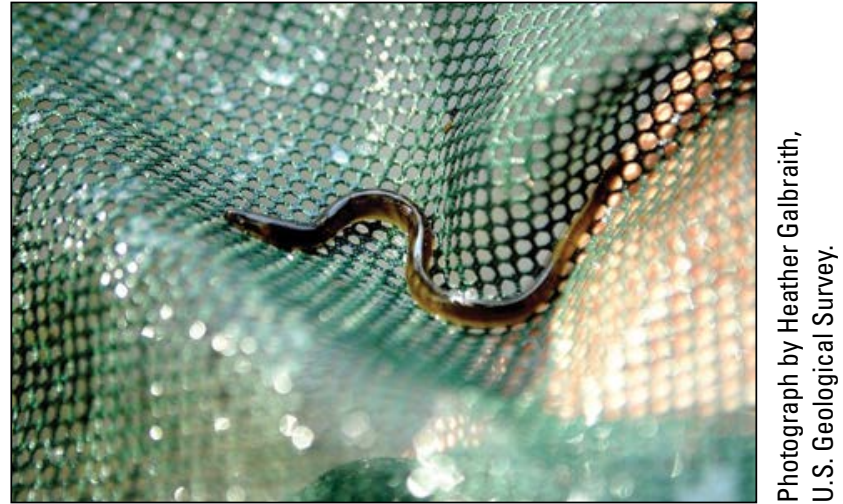

Young American eels, such as the one pictured here, are beginning to recolonize streams in Shenandoah National Park after the removal of a dam more than 145 kilometers (90 miles) downstream.

(304) $724-4467$

\section{Publications}

Smith, D.R., Fackler, P.L., Ortiz, L.V., and Welsh, S.A., 2017, Optimization of decision rules for hydroelectric operation to reduce both eel mortality and unnecessary turbine shutdown - A search for a win-win solution: Rivers Research and Applications, prepublication early view, https://doi.org/10.1002/rra.3182.

Eyler, S.M., Welsh, S.A., Smith, D.R., and Rockey, M.M., 2016, Downstream passage and impact of turbine shutdowns on survival of silver American Eel (Anguilla rostrata) at five hydroelectric dams on the Shenandoah River: Transactions of the American Fisheries Society, v. 145, no. 5, p. 964-976, https://doi.org/10.1080/00028487.2016.1176954.

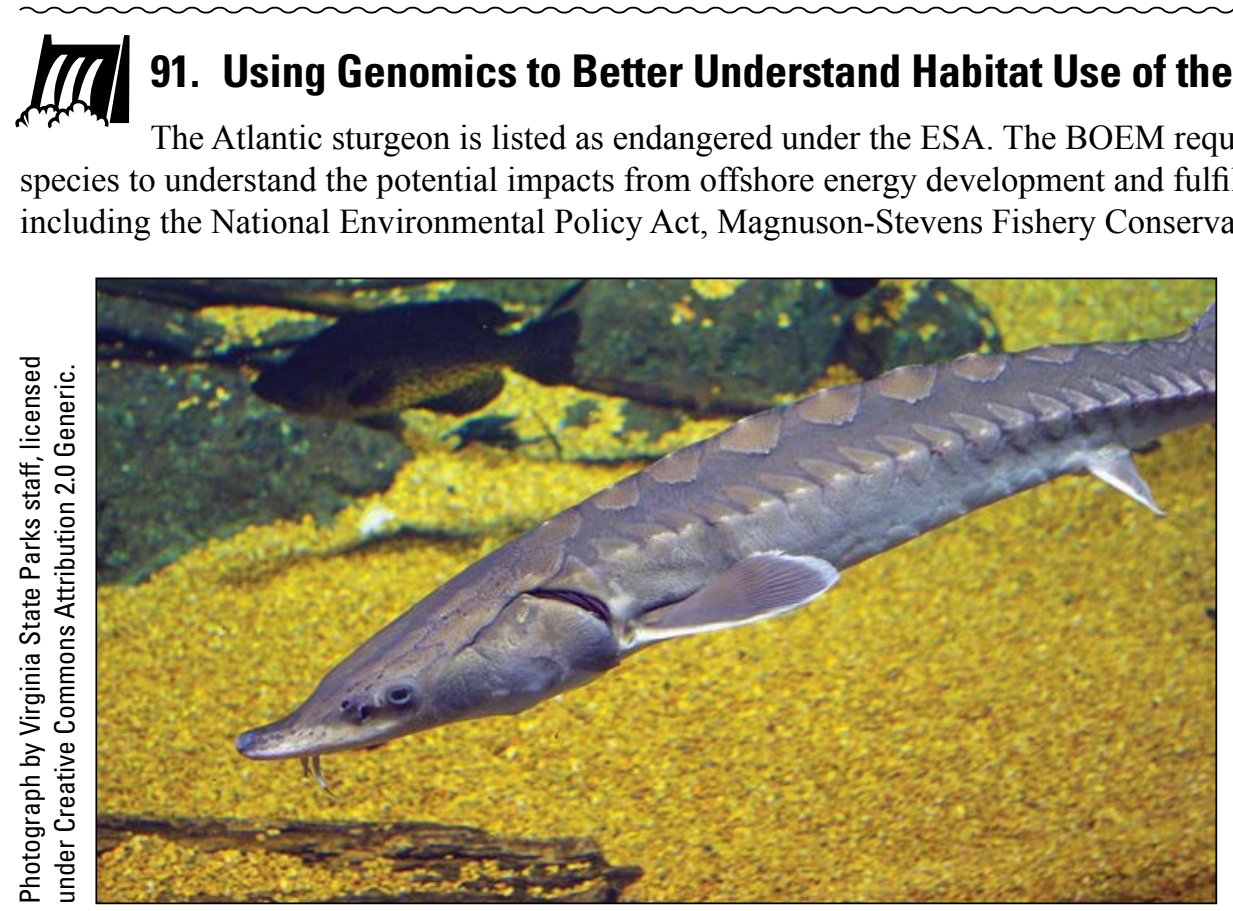

Altantic sturgeon.
Atlantic sturgeon use of coastal waters is poorly understood. The USGS is developing genomics tools aimed at providing a cost-effective, high-resolution approach for characterizing population structure and demographics. The USGS has assembled and annotated the complete mitochondrial genome of both the Atlantic and Gulf sturgeon which can now be used to detect Atlantic and Gulf sturgeon DNA sampled from water (referred to as environmental DNA or eDNA). These techniques can allow large numbers of sturgeon to be assigned to their river and distinct population segment of origin, and facilitate accurate assessments of impact 
on Atlantic sturgeon populations. These approaches are widely applicable to stock and impact assessments for a wide variety of imperiled or other species of management concern.

\section{Contacts}

Stephen Faulkner, USGS Leetown Science Center, faulkners@usgs.gov, (304) 724-4471

David Kazyak, USGS Leetown Science Center, dkazyak@usgs.gov, (304) 724-4577

\section{Publications}

Fritts, M.W., Grunwald, Cheryl, Wirgin, Isaac, King, T.L., and Peterson, D.L., 2016, Status and genetic character of Atlantic sturgeon in the Satilla River, Georgia: Transactions of the American Fisheries Society, v. 145, no. 1, p. 69-82, https://doi.org/10.1080/00028487.2015.1094131.

Wirgin, Isaac, Breece, M.W., Fox, D.A., Maceda, Lorraine, Wark, K.W., and King, Tim, 2015, Origin of Atlantic sturgeon collected off the Delaware Coast during spring months: North American Journal of Fisheries Management, v. 35, no. 1, p. 20-30, https://doi.org/10.1080/02755947.2014.963751.

Wirgin, I., Maceda, L., Grunwald, C., and King, T.L., 2015, Population origin of Atlantic sturgeon Acipenser oxyrinchus oxyrinchus by-catch in U.S. Atlantic coast fisheries: Journal of Fish Biology, v. 86, no. 4, p. 1251-1270, https://doi.org/10.1111/jfb.12631.

O'Leary, S.J., Dunton, K.J., King, T.L., Frisk, M.G., and Chapman, D.D., 2014, Genetic diversity and effective size of Atlantic sturgeon, Acipenser oxyrinchus oxyrinchus river spawning populations estimated from the microsatellite genotypes of marine-captured juveniles: Conservation Genetics, v. 15, no. 5, p. 1173-1181, https://doi.org/10.1007/s10592-014-0609-9.

\section{92. Developing Selective Fish Passage to Block Invasive Sea Lamprey}

The sea lamprey is an invasive, parasitic fish species in the Great Lakes, causing damage to recreational and commercial fisheries estimated at $\$ 7$ billion annually. USGS scientists, in collaboration with the Great Lakes Fisheries Commission, University of Massachusetts, Michigan State University, and the University of Guelph, are evaluating velocitybased barriers, nonstick surfaces, and other strategies that take advantage of the relatively poor swimming abilities of lamprey. The goal is to develop selective fish passage that would block the passage of sea lamprey while allowing desirable fish species to pass through unharmed.

\section{Contact}

Theodore Castro-Santos, USGS Leetown Science Center, tcastrosantos@usgs.gov, (413) 863-3838

\section{Publications}

Rous, A.M., McLean, A.R., Barber, Jessica, Bravener,

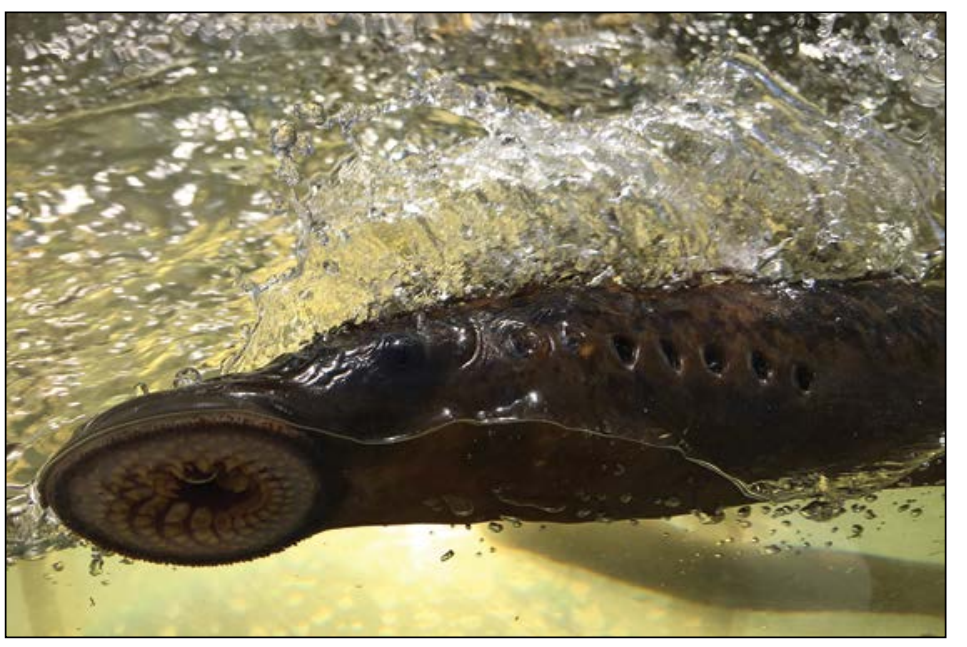

Selective fish passage surfaces are tested in a flow device at the S.O. Conte Anadromous Fish Research Center to block sea lamprey movement across fish passageways.

G.A., Castro-Santos, Theodore, Holbrook, C.M., Imre, István, Pratt, T.C., and McLaughlin, R.L., 2017, Spatial mismatch between sea lamprey behaviour and trap location explains low success at trapping for control: Canadian Journal of Fisheries and Aquatic Sciences, 49 p., https://doi.org/10.1139/cjfas-2016-0445.

Castro-Santos, Theodore, Sanz-Ronda, F.J., Ruiz-Legazpi, Jorge, and Jonsson, Bror, 2013, Breaking the speed limitComparative sprinting performance of brook trout (Salvelinus fontinalis) and brown trout (Salmo trutta): Canadian Journal of Fisheries and Aquatic Sciences, v. 70, no. 2, p. 280-293, https://doi.org/10.1139/cjfas-2012-0186.

McLaughlin, R.L., Smyth, E.R.B., Castro-Santos, Theodore, Jones, M.L., Koops, M.A., Pratt, T.C., and Vélez-Espino, L.A., 2013, Unintended consequences and trade-offs of fish passage: Fish and Fisheries, v. 14, no. 4, p. 580-604, https://doi.org/10.1111/faf.12003. 


\section{Aquatic Invasive Species Control Efforts and Dam Operations}

Nonnative fishes, some potentially invasive, have been introduced in impoundments throughout the United States to create recreational fishing opportunities. The passage of individual fish and other aquatic organisms through dams as part of hydropower operations can lead to invasions of unwanted species. USGS scientists are developing and testing the feasibility of using methods such as liquid ammonia, carbon dioxide, and sound to eradicate undesirable species upstream and downstream from dams. In one example, green sunfish were successfully eradicated from the Colorado River downstream from the Glen Canyon Dam, thus allowing managers to move forward with an experimental flood without the risk of further spreading an aquatic invasive species in the Colorado River. Current efforts focus on several fish and mollusks, including four species of nonnative Asian carp, Round Goby, and Dreissenid mussels (quagga mussels and zebra mussels).

\section{Contact}

Mark Gaikowski, USGS Upper Midwest Environmental Sciences Center, mgaikowski@usgs.gov, (608) 781-6221

David Ward, USGS Southwest Biological Science Center, dlward@usgs.gov, (928) 556-7280

\section{Publications}

Cupp, A.R., Erickson, R.A., Fredricks, K.T., Swyers, N.M., Hatton, T.W., and Amberg, J.J., 2017, Responses of invasive silver and bighead carp to a carbon dioxide barrier in outdoor ponds: Canadian Journal of Fisheries and Aquatic Sciences, v. 74, no. 3, p. 297-305, https://doi.org/10.1139/cjfas-2015-0472.

Cupp, A.R., Woiak, Zebadiah, Erickson, R.A., Amberg, J.J., and Gaikowski, M.P., 2017, Carbon dioxide as an under-ice lethal control for invasive fishes: Biological Invasions, p. 1-10, https://doi.org/10.1007/s10530-017-1462-9.

Waller, D.L., Bartsch, M.R., Fredricks, K.T., Bartsch, L.A., Schleis, S.M., and Lee, S.H., 2017, Effects of carbon dioxide on juveniles of the freshwater mussel (Lampsilis siliquoidea [Unionidae]): Environmental Toxicology and Chemistry, v. 36, no. 3, p. 671-681, https://doi.org/10.1002/etc.3567.

Donaldson, M.R., Amberg, Jon, Adhikari, Shivani, Cupp, Aaron, Jensen, Nathan, Romine, Jason, Wright, Adam, Gaikowski, Mark, and Suski, C.D., 2016, Carbon dioxide as a tool to deter the movement of invasive bigheaded carps: Transactions of the American Fisheries Society, v. 145, no. 3, p. 657-670, https://doi.org/10.1080/00028487.2016.1143397.

Ward, D.L., Morton-Starner, R., and Hedwall, S.J., 2013, An evaluation of liquid ammonia (ammonium hydroxide) as a candidate piscicide: North American Journal of Fisheries Management, v. 33, no. 2, p. 400-405, https://doi.org/10.1080/02755947.2013.765528.

\section{(UL) 94. Natural Salmon Recolonization Following Condit Dam Removal}

Condit Dam on the White Salmon River, Washington, was breached in 2011 and removed completely in 2012, allowing anadromous salmonids access to habitat that had been blocked for nearly 100 years. A multiagency workgroup concluded that the preferred salmonid restoration alternative was natural recolonization with monitoring to assess efficacy, followed by a management evaluation 5 years after dam removal. In 2016, USGS scientists, in cooperation with the Mid-Columbia Fisheries Enhancement Group, assessed juvenile salmonid diversity, distribution, and abundance. The 2016 efforts provided the first post-dam smolt and juvenile abundance estimates for coho salmon

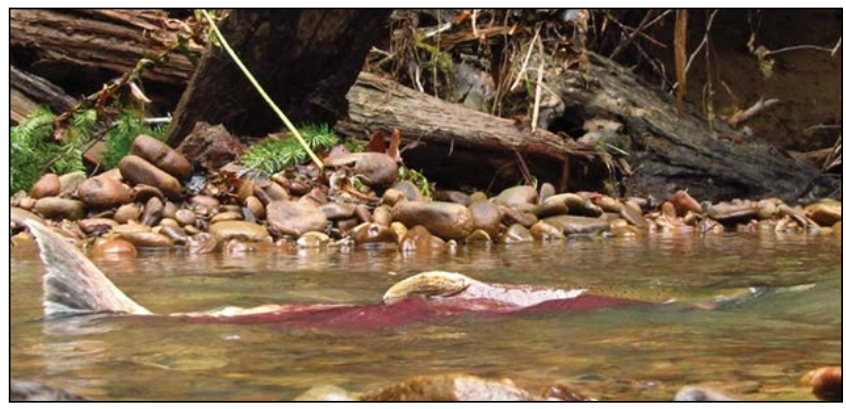

A spawning coho salmon with fins just above the water surface. Female coho select breeding sites on the basis of specific characteristics that offer protection and desired habitat for juveniles. and steelhead as well as the first documentation of coho salmon juvenile production in tributaries upstream from the former Condit Dam site. This monitoring effort can help to better understand abundance trends, distribution, and life history patterns of recolonizing salmonids in the White Salmon River and assess efficacy of natural recolonization to inform management decisions.

\section{Contacts}

Jill Hardiman, USGS Western Fisheries Research Center, jhardiman@usgs.gov, (509) 538-2906

Ian Jezorek, USGS Western Fisheries Research Center, ijezorek@usgs.gov, (509) 538-2908 
Publication

Jezorek, I.G., and Hardiman, J.M., 2017, Juvenile salmonid monitoring in the White Salmon River, Washington, post-Condit Dam removal, 2016: U.S. Geological Survey Open-File Report 2017-1070, 34 p., https://doi.org/10.3133/ofr20171070.

\section{Monitoring Total Dissolved Gas in Hydropower Dams Spills}

Spill water from dams contains supersaturated dissolved gases. High dissolved gases increase mortality to fish below dams. The USGS, in cooperation with the U.S. Army Corps of Engineers (USACE), monitors total dissolved gas at USACEowned dams in the Columbia and Willamette River systems. The data from the study are used in real time by USACE dam operators to ensure spills are within the acceptable range of total dissolved gas.

\section{Contact}

Nora Herrera, USGS Oregon Water Science Center, nherrera@usgs.gov, (503) 251-3209

\section{Resources}

USGS National Water Information System database

(https://waterdata.usgs.gov/or/nwis/current/?type=usacetdg\&group_key=basin_cd);

USGS Oregon Water Science Center Lower Columbia River Dissolved Gas Monitoring Network

(https://or.water.usgs.gov/projs_dir/pn307.tdg/)

\section{Maintenance of Instream Flows and Water Temperatures for Salmon Egg Incubation}

The USGS, in cooperation with the Alaska Energy Authority (AEA), collects and analyzes streamflow, water temperature, and intragravel water temperature downstream from the Bradley Lake dam. To protect salmon egg incubation habitat during the winter, a minimum discharge of 1.3 cubic meters per second ( 40 cubic feet per second) in the lower river is maintained. This minimum flow determination was based on an open-water instream flow study that did not take into account the effects of ice formation, which is fatal to eggs. Data are collected to determine if below-freezing temperatures occur at depths 25 to 30 centimeters ( 10 to 12 inches) below the streambed. These data can be used to determine if the minimum instream flow is sufficient to maintain above-freezing temperature in the streambed and allow for salmon egg incubation.

\section{Contact}

Jeff Conaway, USGS Alaska Science Center, jconaway@usgs.gov, (907) 786-7041

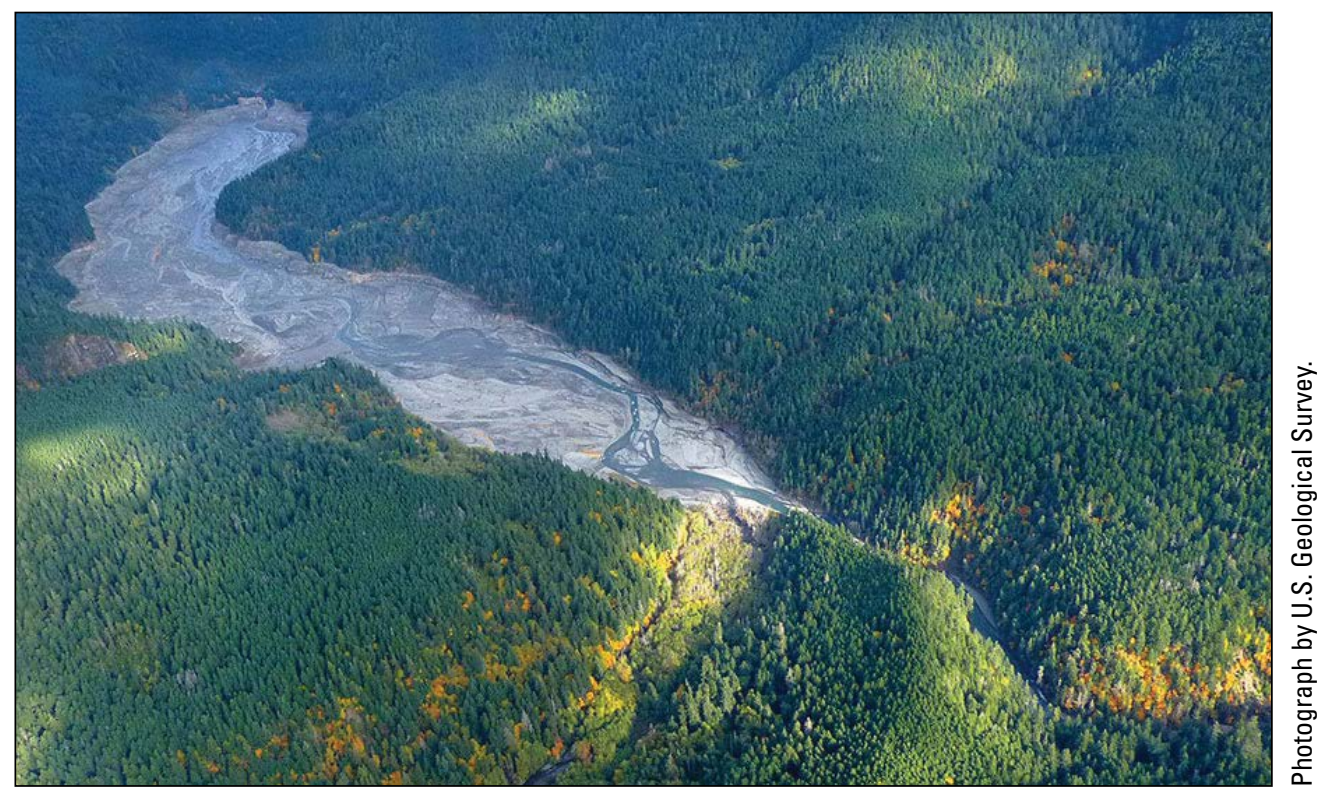

Aerial view of the Elwha River upstream from the dam removal site. 


\section{Improving Stream Temperature With Modification to Hydropower Dam Operation}

The USACE has more than 10 dams in the Willamette watershed. The Willamette Basin biological opinion requires the USACE to assess the feasibility of developing project-specific alternatives for achieving fish passage as well as improved long-term temperature control downstream from these dams. The USGS is using existing models to simulate the effects of structural and operational scenarios and follow the effects downstream. The USACE can use this information to determine the ways in which structural and (or) operational changes to dams can improve downstream water temperature and flow conditions for endangered fish species.

\section{Contact}

Stewart Rounds, USGS Oregon Water Science Center, sarounds@usgs.gov, (503) 251-3280

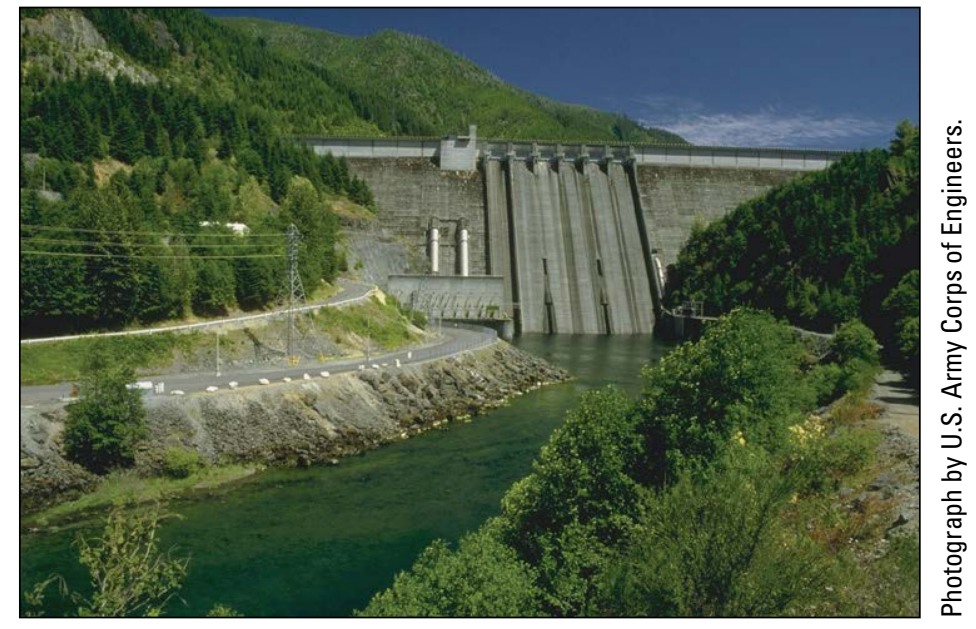

Dam operators for the Detroit Dam on the North Santiam River in Oregon use temperature sensors for direct operational feedback, altering dam operations to create a more-natural seasonal temperature pattern downstream for fish.

\section{Land Use and Microhabitat Effects on Salamanders in the Central Appalachian Coalfields}

The USGS, in cooperation with Virginia Polytechnic Institute and State University, is investigating the utility of using aquatic salamander surveys as a surrogate for costly and complex macroinvertebrate surveys to assess post-mining stream recovery and health in the Central Appalachian coalfields. Some salamander species are identified as tolerant to stream habitat and water-quality degradation while others are only found in streams with high biological integrity. These characteristics allow for a quicker, more cost effective way for scientists and managers to score aquatic health and determine watershed status. Scientists are also examining connections between spatial and land-use data with both salamanders and macroinvertebrates that may result in the development of a stronger watershed assessment tool using spatial imagery matched with water-quality parameters, such as conductivity and total dissolved solids, for large portions of the Central Appalachian coalfields.

\section{Contact}

Mark Ford, USGS Virginia Cooperative Fish and Wildlife Research Unit, wmford@vt.edu, (540) 231-5927

\section{Publications}

Sweeten, S.E., and Ford, W.M., 2016, Effects of microhabitat and large-scale land use on stream salamander occupancy in the coalfields of Central Appalachia: Journal of Ecology and the Natural Environment, v. 8, no. 9, p. 129-141, https://doi.org/10.5897/JENE2016.0564.

Sweeten, S.E., and Ford, W.M., 2016, Validation of a stream and riparian habitat assessment protocol using stream salamanders in the southwest Virginia coalfields: Journal of American Society of Mining and Reclamation, v. 5, no. 1, p. 45-66, https://doi.org/10.21000/jasmr16010045. 


\section{Wildlife Habitats and Ecosystem Functions}

\section{Opportunities for Restoring Monarch Butterfly Habitat in the Midwestern United States}

Monarch butterflies have declined by as much as 80 percent over the last 20 years, in large part because of declines in milkweed, the plant monarchs rely upon for breeding. The USGS, University of Arizona, and partners developed scenarios for incorporating approximately 1.6 billion new milkweed stems into the Midwestern U.S. landscape, the number needed to help restore the eastern migratory monarch population. Scientists evaluated five land-cover sectors to determine the current and potential future ability of the land to support milkweed, including utility and transportation rights-of-way land. They found that converting marginal cropland to monarch-friendly habitat provides the best opportunity for adding milkweed, but emphasize that planting milkweed in other types of lands, including protected areas and urban and suburban locations, is likely necessary to reach project goals.

\section{Contact}

Wayne Thogmartin, USGS Upper Midwest Environmental Sciences Center, wthogmartin@usgs.gov, (608) 781-6309

\section{Publication}

Thogmartin, W.E., López-Hoffman, Laura, Rohweder, Jason, Diffendorfer, Jay, Drum, Ryan, Semmens, Darius, Black, Scott, Caldwell, Iris, Cotter, Donita, Drobney, Pauline, Jackson, L.L., Gale, Michael, Helmers, Doug, Hilburger, Steve, Howard, Elizabeth, Oberhauser, Karen, Pleasants, John, Semmens, Brice, Taylor, Orley, Ward, Patrick, Weltzin, J.F., and Wiederholt, Ruscena, 2017, Restoring monarch butterfly habitat in the Midwestern U.S.- 'all hands on deck': Environmental Research Letters, v. 12, no. 7, http://iopscience.iop.org/article/10.1088/1748-9326/aa7637.

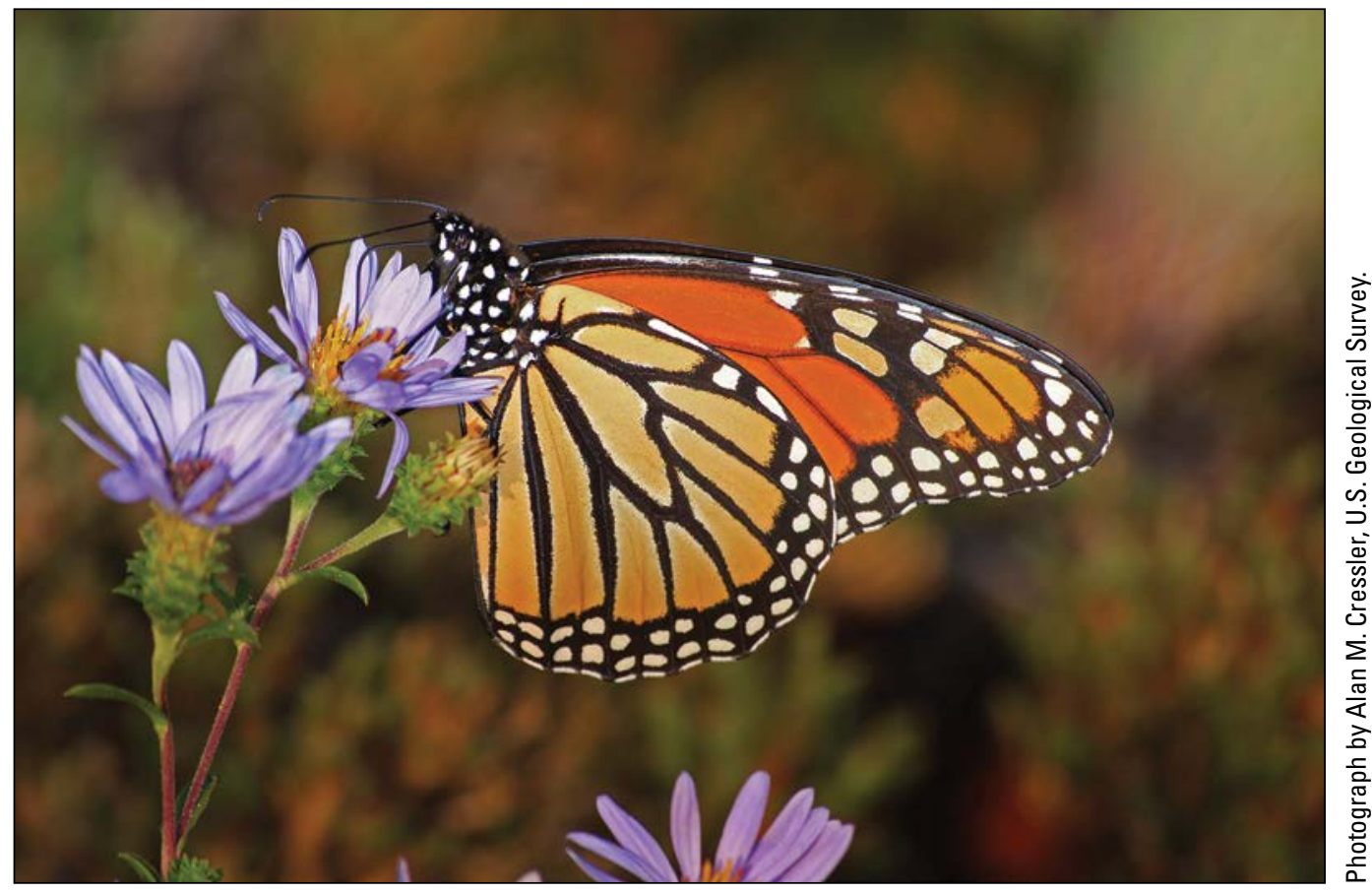

A monarch butterfly feeding on an aster in Pickens County, South Carolina.

\section{Long-Term Recovery of Vegetation Along Utility Lines}

Renewable energy development in the Mojave Desert involves the construction of transmission lines and other linear disturbances in Mojave and Sonoran vegetation. Recovery of habitat along linear disturbances requires decades, if not centuries. Although cover of shrubs, grasses, and annual plants in the Mojave Desert may occur relatively quickly several decades after disturbance, the composition of the plants does not, especially annual plants. Restoring the original composition and diversity remains a challenge to specialists and is likely to require more time when livestock graze a site, a road is adjacent, and with 
increasing local temperatures. Knowledge about the pioneering roles of plant species, their association with other species (for example, nurse species), and successional stages can be applied to truncate the restoration and recovery process. The findings from these studies can be applied to restoration projects in disturbed creosote bush, tree yucca, and other vegetation alliances in the Mojave and other deserts.

\section{Contact}

Kristin H. Berry, USGS Western Ecological Research Center, kristin_berry@usgs.gov, (951) 697-5361

\section{Publications}

Berry, K.H., Weigand, J.F., Gowan, T.A., and Mack, J.S., 2016, Bidirectional recovery patterns of Mojave Desert vegetation in an aqueduct pipeline corridor after 36 years-I. Perennial shrubs and grasses: Journal of Arid Environments, v. 124, p. 413-425, https://doi.org/10.1016/j.jaridenv.2015.03.004.

Berry, K.H., Mack, J.S., Weigand, J.F., Gowan, T.A., and LaBerteaux, Denise, 2015, Bidirectional recovery patterns of Mojave Desert vegetation in an aqueduct pipeline corridor after 36 years-II. Annual plants: Journal of Arid Environments, v. 122, p. 141-153, https://doi.org/10.1016/j.jaridenv.2015.06.016.

\section{Effects of Energy Development on Environmental Resources of the Williston Basin}

Energy development within the Williston Basin, especially development focused on the Bakken Formation, has led to unprecedented natural, social, and cultural change across the Northern Great Plains. This development is expected to continue for at least the next 50 years as energy companies and scientists continue to discover new mineral-producing horizons and innovative technologies for extraction. The USGS developed a report in concert with the Bakken Federal Executive Group to review and synthesize the existing information about air, water, and wildlife resources that may be relevant in understanding the potential effects of oil and gas development in the Williston Basin.

\section{Contact}

Scott Morlock, USGS Midwest Region, smorlock@usgs.gov, (317) 600-2753

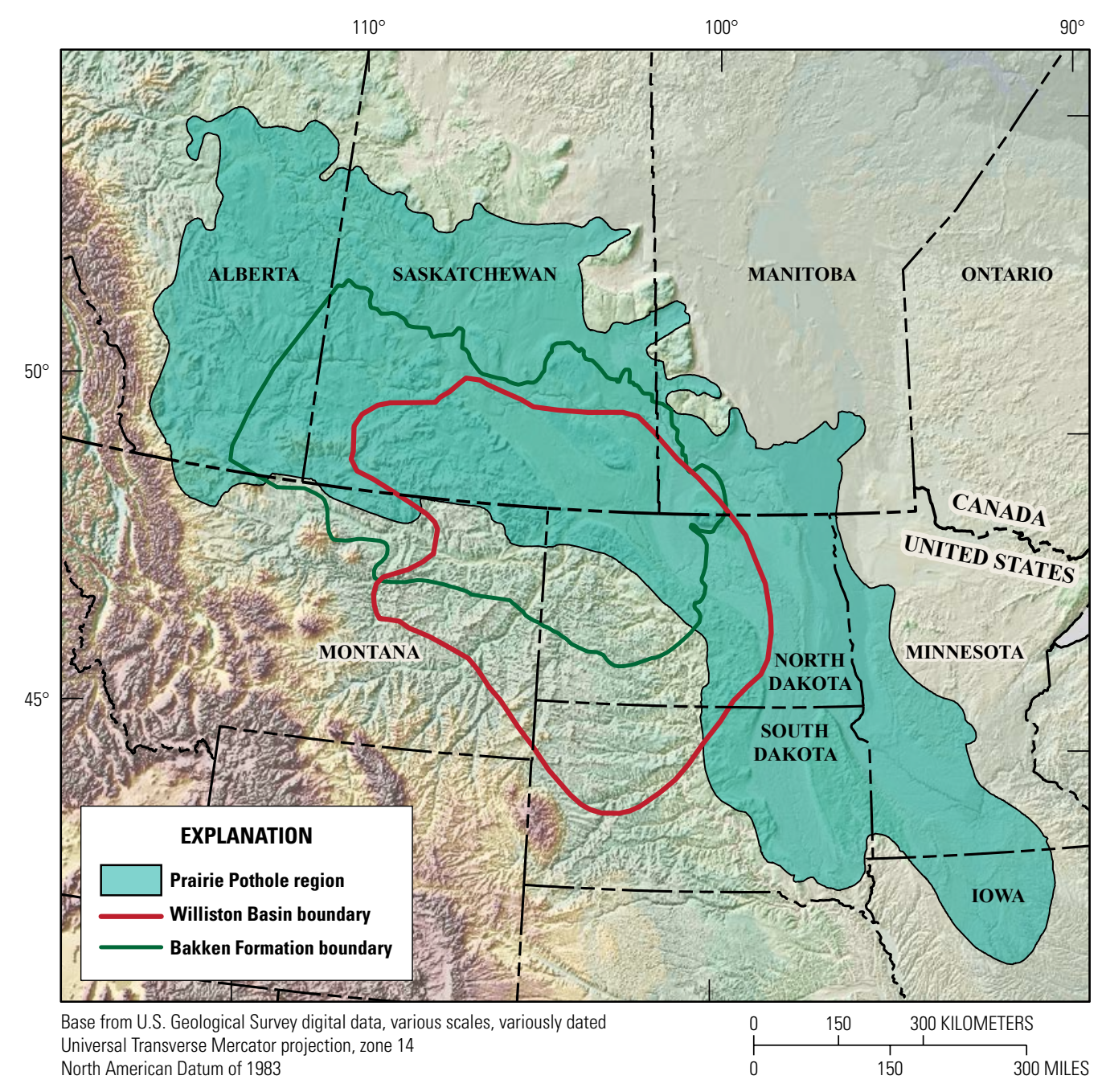

The Williston Basin of Montana and North Dakota is a leading source of domestic oil and gas (from Dennerline and Childs, 2017). 


\section{Evaluating Bioenergy Opportunities in the Southwest}

The USGS is collaborating with the USDA Arid Land Agricultural Research Center and Ohio University regarding the potential for agave biofuel production to add to our national bioenergy portfolio in marginally productive lands. Agave may represent a highly efficient biofuel, even under nonirrigation conditions, but the ecosystem consequences of this development on drylands, including habitat and wildlife, remains unknown. The project aims to explore the potential benefits and drawbacks of biofuel production in the Southwest as an alternative energy source and strategy.

\section{Contact}

Sasha Reed, USGS Southwest Biological Science Center, screed@usgs.gov, (435) 719-2334

\section{Publications}

Tucker, C.L., and Reed, S.C., 2016, Low soil moisture during hot periods drives apparent negative temperature sensitivity of soil respiration in a dryland ecosystem-A multi-model comparison: Biogeochemistry, v. 128, nos. 1-2, p. 155-169, https://doi.org/10.1007/s10533-016-0200-1.

Smith, W.K., Reed, S.C., Cleveland, C.C., Ballantyne, A.P., Anderegg, W.R.L., Wieder, W.R., Liu, Y.Y., and Running, S.W., 2015, Large divergence of satellite and Earth system model estimates of global terrestrial $\mathrm{CO}_{2}$ fertilization: Nature Climate Change, v. 6, no. 3, p. 306-310, https://doi.org/10.1038/nclimate2879.

Smith, W.K., Cleveland, C.C., Reed, S.C., and Running, S.W., 2014,

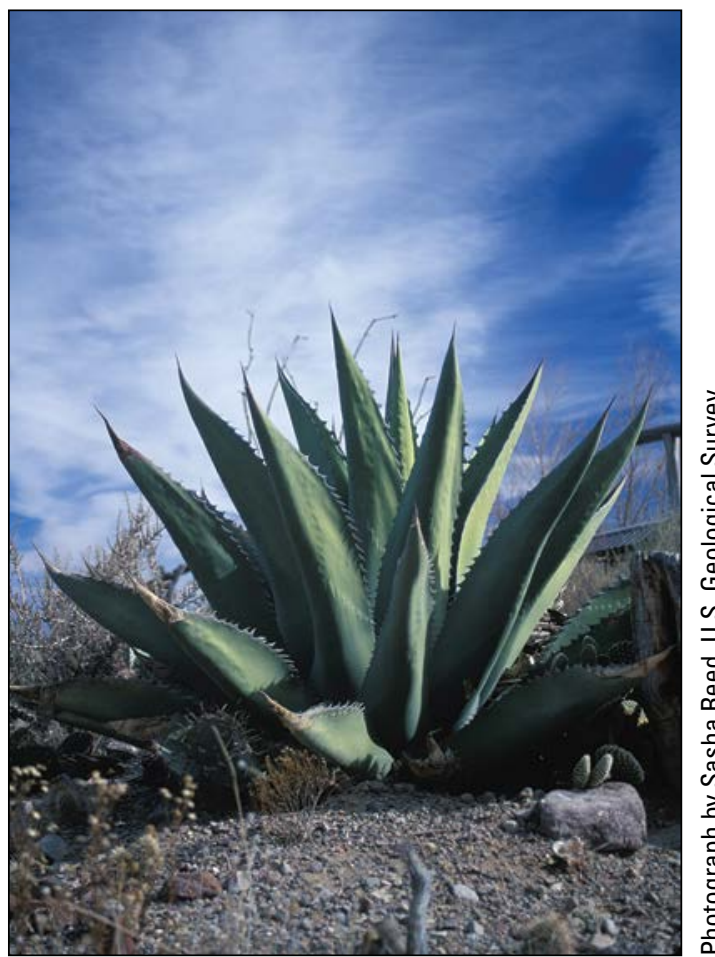

Agave plants at a U.S. Department of Agriculture experimental plot site near Phoenix, Arizona.

Agricultural conversion without external water and nutrient inputs reduces terrestrial vegetation productivity: Geophysical Research Letters, v. 41, no. 2, p. 449-455, https://doi.org/10.1002/2013GL058857.

Smith, W.K., Cleveland, C.C., Reed, S.C., Miller, N.L., and Running, S.W., 2012, Bioenergy potential of the United States constrained by satellite observations and existing productivity: Environmental Science and Technology, v. 46, no. 6, p. 3536-3544, https://doi.org/10.1021/es203935d.

\section{Land-Cover Changes Associated With Recent Energy Development in the Williston Basin}

The Williston Basin in the Northern Great Plains has experienced rapid energy development since 2000. USGS scientists evaluated land-cover changes from recent (2000-15) development and found that the development had converted 12,990 hectares (50 square miles) of predominantly agricultural or prairie land and had disturbed an additional 12,121 hectares (47 square miles). Future land-cover changes are forecasted to be 2.7 times greater than the evaluated period based on the number of wells expected by 2050 as reported by the North Dakota Department of Mineral Resources in 2014 (https://www.dmr.nd.gov/oilgas/presentations/NDOGCPC091814.pdf). Although future development may result in substantial land-cover change, evolving industry practices and proactive siting decisions, such as development along energy corridors and placing pads in areas previously altered by human activity, have the potential to reduce the ecological effects of future energy development in the Williston Basin.

\section{Contact}

Todd Preston, USGS Northern Rocky Mountain Science Center, tmpreston@usgs.gov, (406) 994-5034

\section{Publication}

Preston T.M., and Kim, Kevin, 2016, Land cover changes associated with recent energy development in the Williston Basin, Northern Great Plains, U.S.A.: Science of the Total Environment, v. 566-567, p. 1511-1518, https://doi.org/10.1016/j.scitotenv.2016.06.038. 


\section{Ecological Effects of Brine Contamination in the Prairie Pothole Region}

Energy production in the Williston Basin results in the co-production of highly saline water, or brine. USGS researchers examined the effects of contamination from production waters derived from oil and gas development on macroinvertebrate communities and above-ground biomass and plant tissue chemistry of hardstem bulrush. Scientists sampled 10 wetlands across a contamination gradient in the Prairie Pothole Region (PPR) and collected samples to determine macroinvertebrate taxonomic richness, biomass, and plant tissue chloride concentrations. Across this gradient, a significant decrease in taxonomic richness and biomass of hardstem bulrush as well as an increase in plant tissue chloride concentration was documented with increased co-produced water contamination. These results can provide information on potential effects of production brine on primary productivity and benthic biota in PPR wetlands.

\section{Contact}

Todd Preston, USGS Northern Rocky Mountain Science Center, tmpreston@usgs.gov, (406) 994-5034

\section{Publication}

Preston, T.M., and Ray, A.M., 2017, Effects of energy development on wetland plants and macroinvertebrate communities in Prairie Pothole Region wetlands: Journal of Freshwater Ecology, v. 32, no. 1, p. 29-34, https://doi.org/10.1080/02705060.2016.1231137.
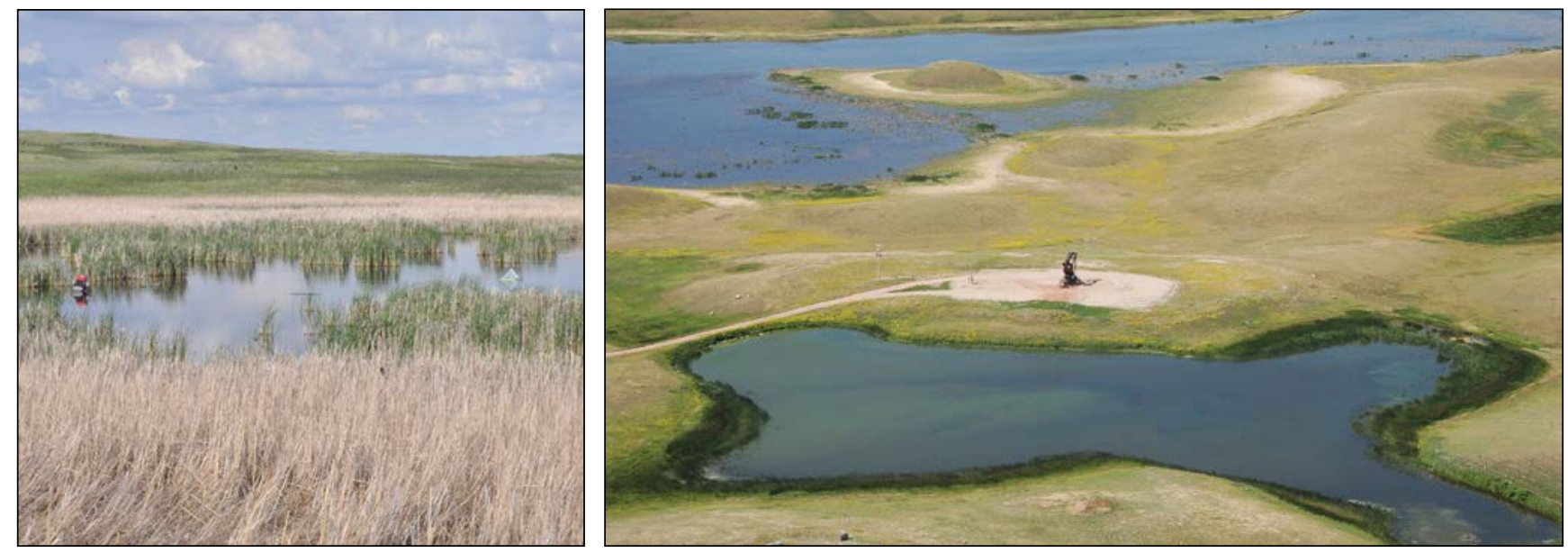

Insect traps in a wetland in North Dakota's Prairie Pothole Region.

\section{Shifts in Microbial Resistance Mechanisms in Surface Waters Impacted by Unconventional Oil and Gas (UOG) Wastewaters}

The USGS and Rutgers University identified the environmental health impacts of UOG wastewater disposal activities using microbiomes as a proxy for ecological shifts. Microbiomes were assessed in stream samples at a West Virginia injection well disposal site, including sites upstream, on, and downstream from the disposal facility, and a background site in a separate drainage, by using metagenomics and quantitative polymerase chain reaction (PCR) for antibiotic resistance genes. Microbial communities and antibiotic resistance profiles shifted at impacted sites, and antibiotic resistance genes were found to be less abundant than in municipal wastewater. This study helps identify changes in the microbial community in an environment impacted by UOG wastewater. Shifts in microbial function can alter ecosystem processes, such as nutrient cycling, and can alter the resiliency of a community to perturbation.

\section{Contact}

Isabelle Cozzarelli, USGS National Research Program, icozzare@usgs.gov, (703) 648-5899

\section{Publication}

Fahrenfeld, N.L., Delos Reyes, Hannah, Eramo, Alessio, Akob, D.M., Mumford, A.C., and Cozzarelli, I.M., 2016, Shifts in microbial community structure and function in surface waters impacted by unconventional oil and gas wastewaters revealed by metagenomics: Science of the Total Environment, v. 580, p. 1205-1213, https://doi.org/10.1016/j.scitotenv.2016.12.079. 


\section{Biogeochemistry and Toxicology of a Stream Impacted by Unconventional Oil and Gas (UOG) Wastewater Disposal Operations}

The USGS assessed the inorganic and organic chemistry and cell line toxicity in stream samples at a West Virginia injection well disposal site, including sites upstream, on, and downstream from the disposal facility, and at a background site in a separate drainage. Sites downstream from the UOG wastewater disposal facility contained inorganic and organic compounds in both water and sediments that were consistent with a source from UOG wastewater. Toxicological assays of human cell line exposures to water and sediment showed minimal effects. Results indicated that UOG wastewater had entered the stream; however, the contamination level was low and appeared to be restricted to sites immediately downstream from the disposal facility.

\section{Contacts}

Denise Akob, USGS National Research Program, dakob@usgs.gov, (703) 648-5819

Isabelle Cozzarelli, USGS National Research Program, icozzare@usgs.gov, (703) 648-5899

\section{Publications}

Orem, William, Varonka, Matthew, Crosby, Lynn, Haase, Karl, Loftin, Keith, Hladik, Michelle, Akob, D.M., Tatu, Calin, Mumford, Adam, Jaeschke, Jeanne, Bates, Anne, Schell, Tiffany, and Cozzarelli, Isabelle, 2017, Organic geochemistry and toxicology of a stream impacted by unconventional oil and gas wastewater disposal operations: Applied Geochemistry, v. 80, p. 155-167, https://doi.org/10.1016/j.apgeochem.2017.02.016.

Akob, D.M., Mumford, A.C., Orem, W.H., Engle, M.A., Klinges, J.G., Kent, D.B., and Cozzarelli, I.M., 2016, Wastewater disposal from unconventional oil and gas development degrades stream quality at a West Virginia injection facility: Environmental Science and Technology, v. 50, no. 11, p. 5517-5525, https://doi.org/10.1021/acs.est.6b00428.

\section{Terrestrial Impacts of Mountaintop Mining}

Ecological research on mountaintop mining has been focused on aquatic impacts because the overburden, or mountaintop, is disposed of in nearby valleys, which leads to a wide range of water-quality impacts on streams. Numerous impacts on the terrestrial environment from mountaintop mining also have been largely overlooked, even though they are no less wide ranging, severe, and multifaceted. USGS scientists are reviewing the impacts of mountaintop mining on the terrestrial environment by exploring six broad themes: the loss of topographic complexity, forest loss and fragmentation, forest succession and soil loss, forest loss and carbon sequestration, biodiversity, and human health and well-being. These studies can assist managers and regulators in evaluating the full impacts of mountaintop mining by complementing existing research focused on impacts to aquatic environments.

\section{Contact}

Petra Wood, USGS West Virginia Cooperative Fish and Wildlife Research Unit, pbwood@wvu.edu, (304) 293-5090

\section{Publications}

Williams, J.M., Brown, D.J., and Wood, P.B., 2017, Responses of terrestrial herpetofauna to persistent, novel ecosystems resulting from mountaintop removal mining: Journal of Fish and Wildlife Management, prepublication early view, http://fwspubs.org/doi/abs/10.3996/102016-JFWM-079?code=ufws-site.

Wickham, James, Wood, P.B., Nicholson, M.C., Jenkins, William, Druckenbrod, Daniel, Suter, G.W., Strager, M.P., Mazzarella, Christine, Galloway, Walter, and Amos, John, 2013, The overlooked terrestrial impacts of mountaintop mining: BioScience, v. 63, no. 5, p. 335-348, https://doi.org/10.1525/bio.2013.63.5.7. 


\section{Bioenergy Production and Landscape Change in the Southeastern United States}

The production of woody biomass for bioenergy has the potential to cause substantial landscape change and related effects on forest ecosystems, yet the landscape effects of alternative production scenarios have not been fully assessed. In a recent study, USGS researchers simulated landscape change from 2010 to 2050 under five scenarios of woody biomass production for wood pellets and liquid biofuels in North Carolina, a region that is a substantial producer of wood biomass for bioenergy and contains high biodiversity. Another USGS study used a forest economics model, spatially explicit state-and-transition simulation models, and species-habitat models to project change in habitat amount for 16 wildlife species from reaching a renewable fuel target and expected demand for wood pellets in North Carolina. These studies show that bioenergy feedstock portfolio decisions may affect landscape-scale impacts on wildlife habitat among species.

\section{Contacts}

Jaime Collazo, USGS North Carolina Cooperative Fish and Wildlife Research Unit, Jaime_collazo@ncsu.edu, (919) 515-8837

Nathan Tarr, USGS North Carolina Cooperative Fish and Wildlife Research Unit, nmtarr@ncsu.edu, (919) 513-7280

\section{Publications}

Costanza, G.K., Abt, R.C., McKerrow, A.J., and Collazo, J.A., 2016, Bioenergy production and forest landscape change in the Southeastern United States: GCB Bioenergy, unpaginated, https://doi.org/10.1111/ gcbb. 12386.

Tarr, N.M., Rubino, M.J., Costanza, J.K., McKerrow, A.J., Collazo, J.A., and Abt, R.C., 2016, Projected gains and losses of wildlife habitat from bioenergy-induced landscape change: GCB Bioenergy, unpaginated, https://doi.org/10.1111/ gcbb. 12383 .

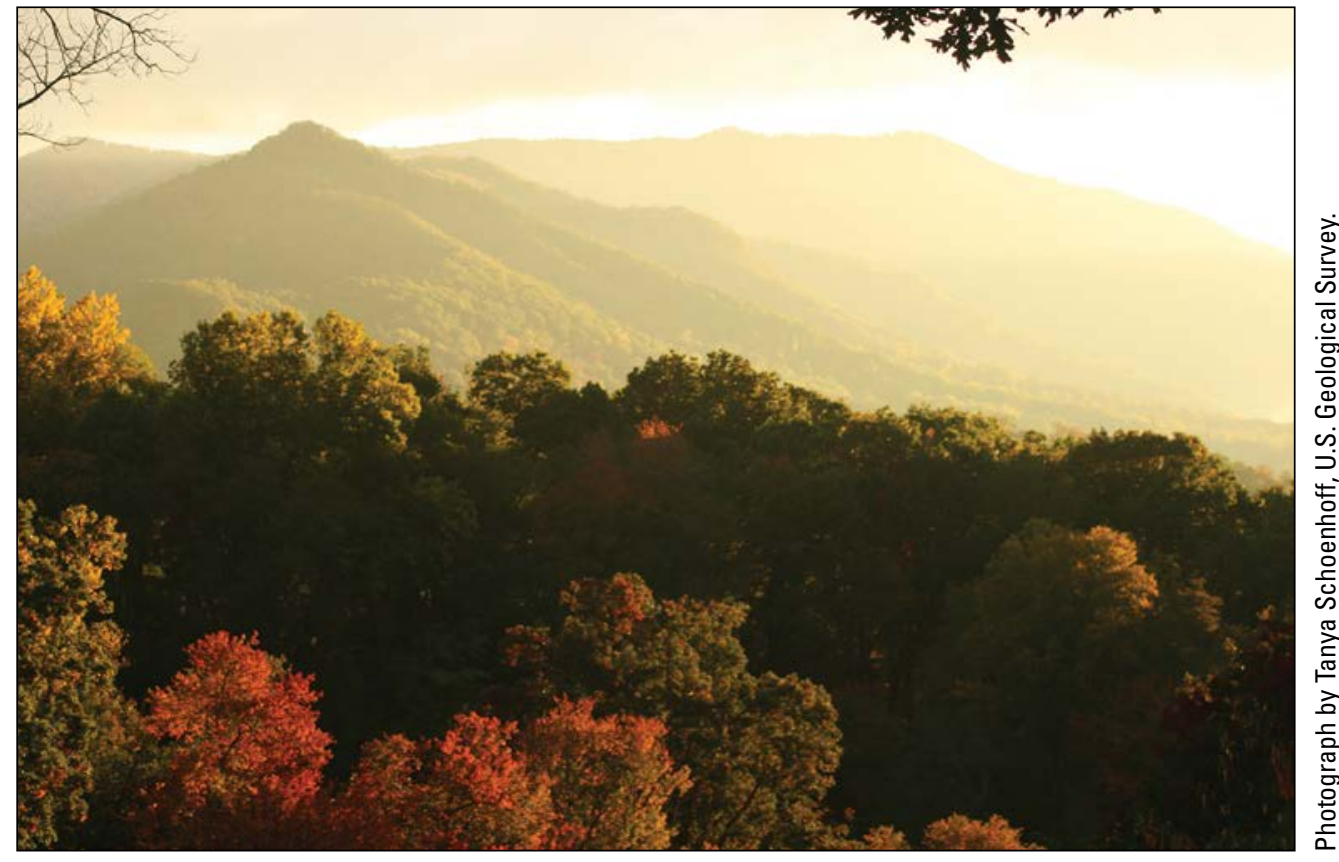

Evening sunset over the mountains in Waynesville, North Carolina.

\section{Predicting the Effects of Wave Energy Facilities on Nearshore Ecosystems}

The USGS is investigating the possible effects of wave energy conversion (WEC) devices on nearshore ecosystems, such as kelp forests. WEC devices pull potential energy from the rise and fall or surge of open ocean swells and convert it into energy for human use. WEC devices can affect the local environment through noise, hazard, construction, anchoring, animal entanglement, turbulence, sedimentation, fouling, and reduction in wave height. Results from these studies can help BOEM determine the degree to which WECs affect currents and other physical features of the marine environment. BOEM anticipates receiving applications for WEC devices on the Pacific Outer Continental Shelf in the coming years.

\section{Contact}

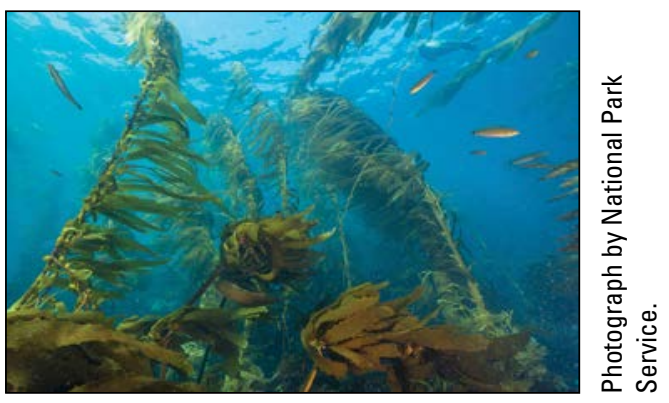

Kevin Lafferty, USGS Western Ecological Research Center, klafferty@usgs.gov, (805) 893-8778 


\section{Conservation and Energy Development Planning Tools}

\section{Sensitive and Rare Plant Distributions and Energy Development in the Colorado Plateau}

USGS scientists have developed optimization models to identify lands where management and conservation conflicts between energy development and sensitive and rare plant species could be minimized. As part of this effort, scientists organized existing data on 21 federally listed, rare and sensitive plant species in the Colorado Plateau. Scientists also are collecting new data on plant locations and developing distribution models, indicating the likelihood of plants being present in specified locations. The plant species distribution models are being analyzed in relation to existing and proposed renewable and oil and gas energy development in the Colorado Plateau. Results from this study can help decision makers select variable risk strategies depending on desired management and energy development goals.

Contact

Thomas Edwards, USGS Utah Cooperative Fish and Wildlife Research Unit, t.edwards@nr.usu.edu, (435) 797-2529

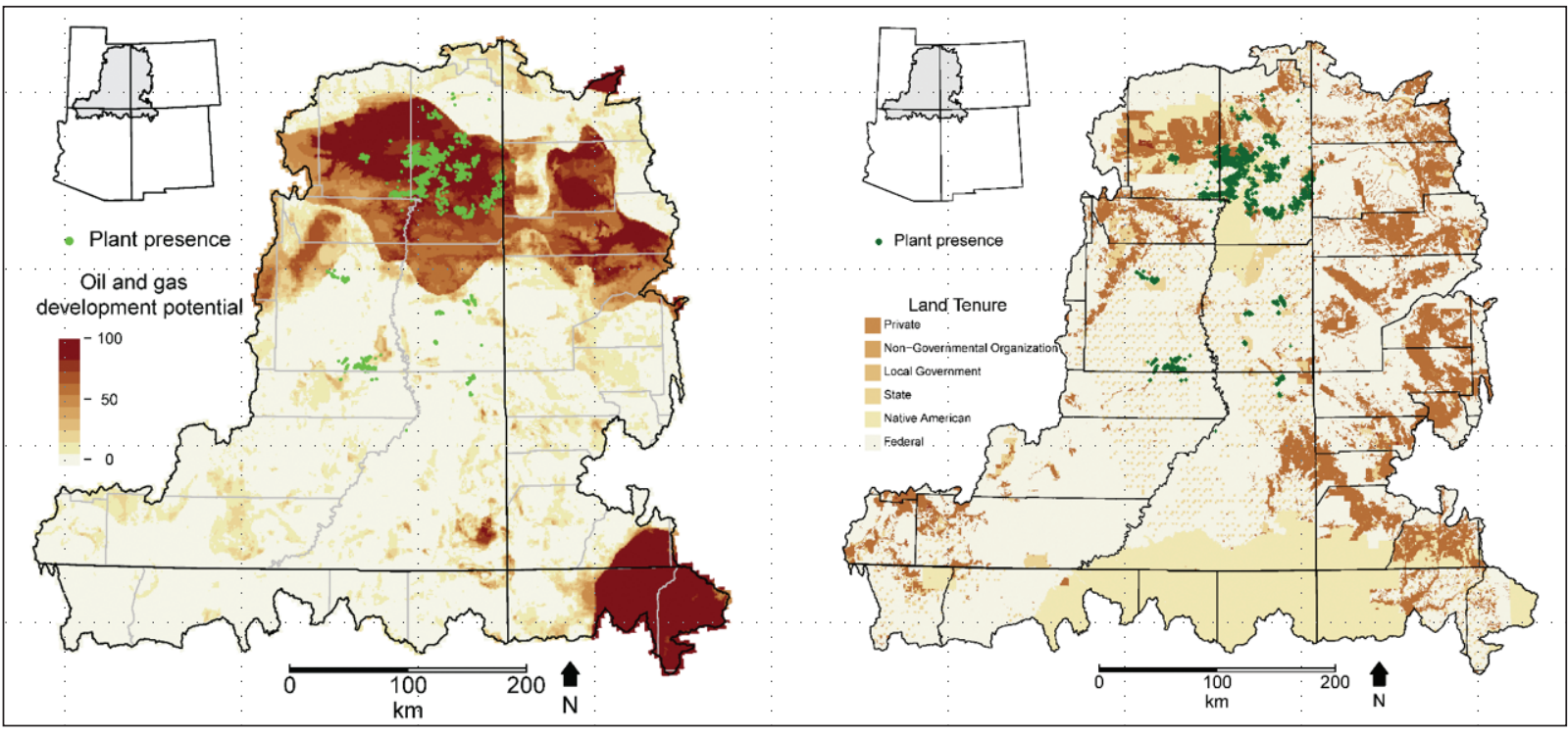

Locations of sensitive and rare plants and their overlap (shown in green) with areas of energy potential and land ownership.

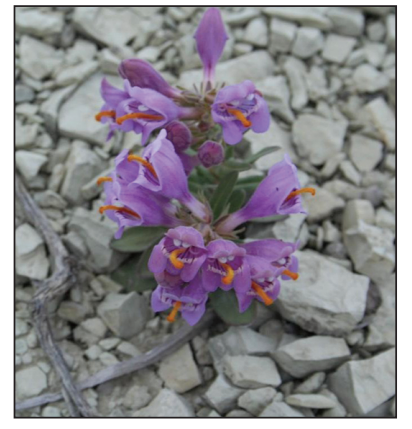

Graham's beardtongue.

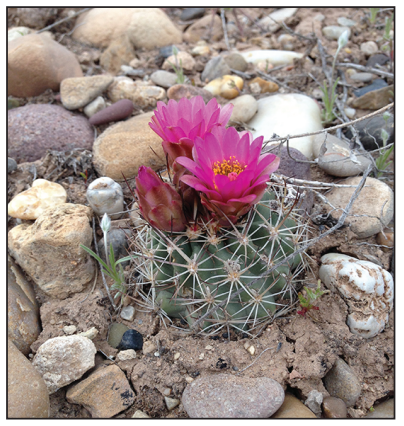

The Uinta Basin hookless cactus is listed as threatened by the ESA.

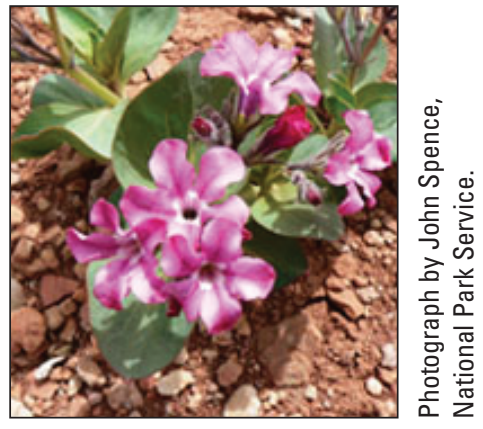

The Jones cycladenia is only found on certain geologic formations in Utah and Arizona. 

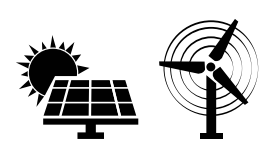

\section{Ecological Restoration and Native Plant Development in Hot Desert Systems}

Energy development across the Mojave and Sonoran deserts has increased the demand for more effective restoration techniques and appropriate plant materials for seeding and planting disturbed areas. In collaboration with Rancho Santa Ana Botanical Garden, Texas State University, BLM, and USFWS, the USGS developed seed-transfer zones at a resolution appropriate to guide seed-collection activities across the Mojave Desert. A network of experimental gardens incorporates research on germination, establishment, and survivorship with landscape genetics and physiology on a variety of key native plant species.

\section{Contacts}

Lesley DeFalco, USGS Western Ecological Research Center, ldefalco@usgs.gov, (702) 564-4507

Todd Esque, USGS Western Ecological Research Center, tesque@usgs.gov, (702) 564-4506

\section{Publications}

Shryock, D.F., Havrilla, C.A., DeFalco, L.A., Esque, T.C., Custer, N.A., and Wood, T.E., 2016, Landscape genetic approaches to guide native plant restoration in the Mojave Desert: Ecological Applications v. 27, no. 2, p. 429-445, https://doi.org/10.1002/eap.1447.

Shryock, D.F., Havrilla, C.A., Esque, T.C., Custer, N.A. Nakazato, T., DeFalco, L.A., and Wood, T.E., 2015, Landscape genomics of Sphaeralcea ambigua in the Mojave Desert-A multivariate, spatially-explicit approach to guide its use in ecological restoration: Conservation Genetics, v. 16, no. 6, https://doi.org/10.1007/s10592-015-0741-1.

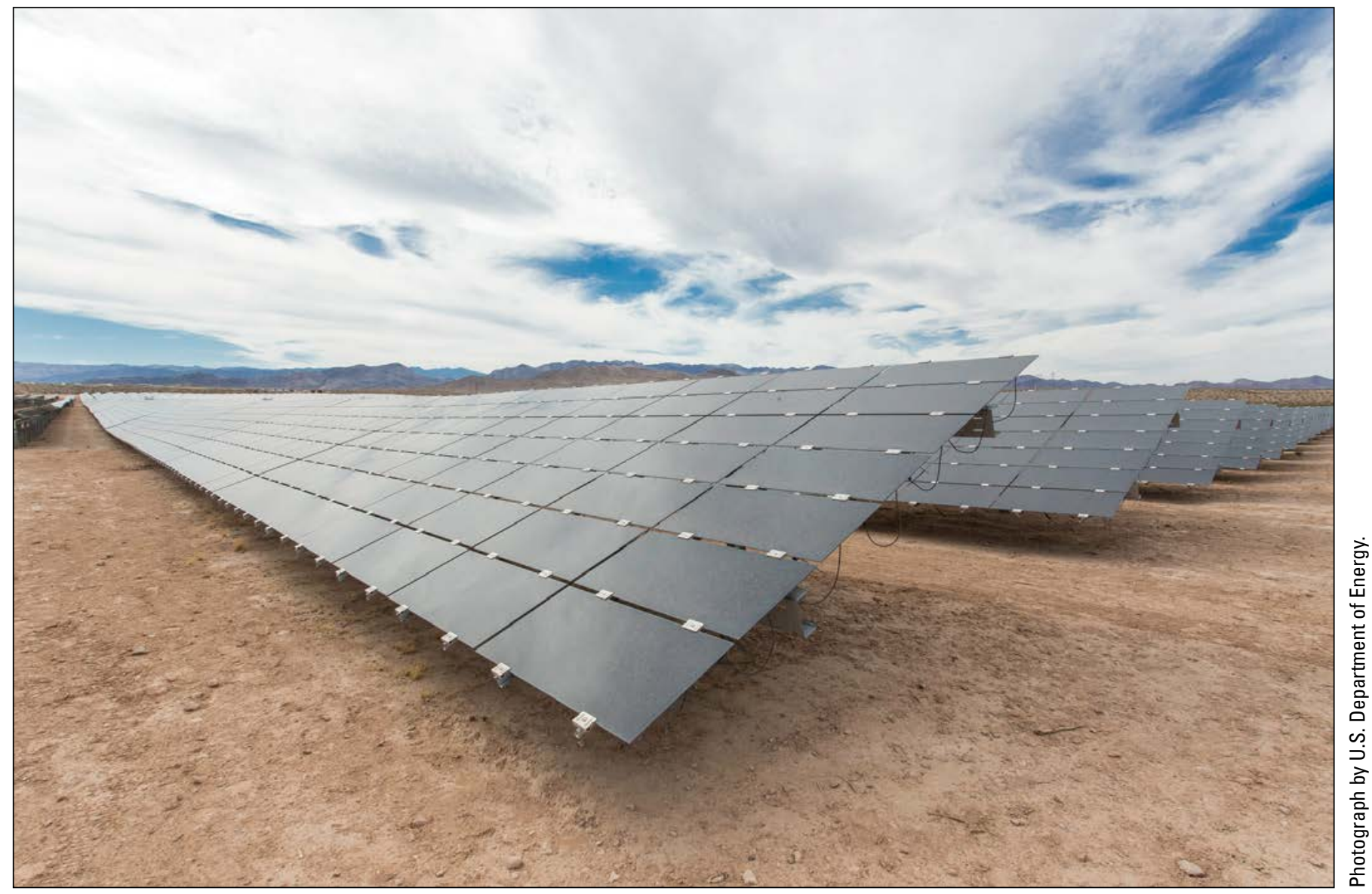

Utility-scale solar array on Moapa Band of Paiutes Indian land, Nevada. 


\section{Evaluating Reclamation Success Following Oil and Gas Development}

USGS scientists developed a new tool to provide regional assessments of land recovery following oil and gas drilling activities. This new tool was developed to help resource managers make informed decisions for future well pad development. The tool incorporates satellite imagery, digital soil mapping, predictive ecological modeling, and field assessments to evaluate vegetation recovery following well pad abandonment. Scientists used the tool to study 1,800 well pads in Utah, Colorado, and New Mexico. Satellite imagery was used to compare vegetation cover of the abandoned sites to surrounding undisturbed areas with roughly equivalent climate, soil, topography, and management histories. Findings showed that most abandoned oil and gas pads in the study were characterized by more bare ground and less vegetation than surrounding undisturbed areas, even more than 9 years after well abandonment. Differing recovery rates across environmental gradients and land stewardship suggest that these findings can be useful for identifying conditions that may promote or hamper pad recovery.

\section{Contact}

Michael Duniway, USGS Southwest Biological Science Center, mduniway@usgs.gov, (435) 719-2330

\section{Publications}

Nauman, T.W., Duniway, M.C., Villarreal, M.C., and Poitras, T.B., 2017, Disturbance automated reference toolset (DART) Assessing patterns in ecological recovery from energy development on the Colorado Plateau: Science of The Total Environment, v. 584-585, p. 476-488, https://doi.org/10.1016/j.scitotenv.2017.01.034.

Nauman, T.W., and Duniway, M.C., 2016, The automated reference toolset-A soil-geomorphic ecological potential matching algorithm: Soil Science Society of America Journal, v. 80, no. 5, p. 1317-1328, https://doi.org/10.2136/sssaj2016.05.0151.
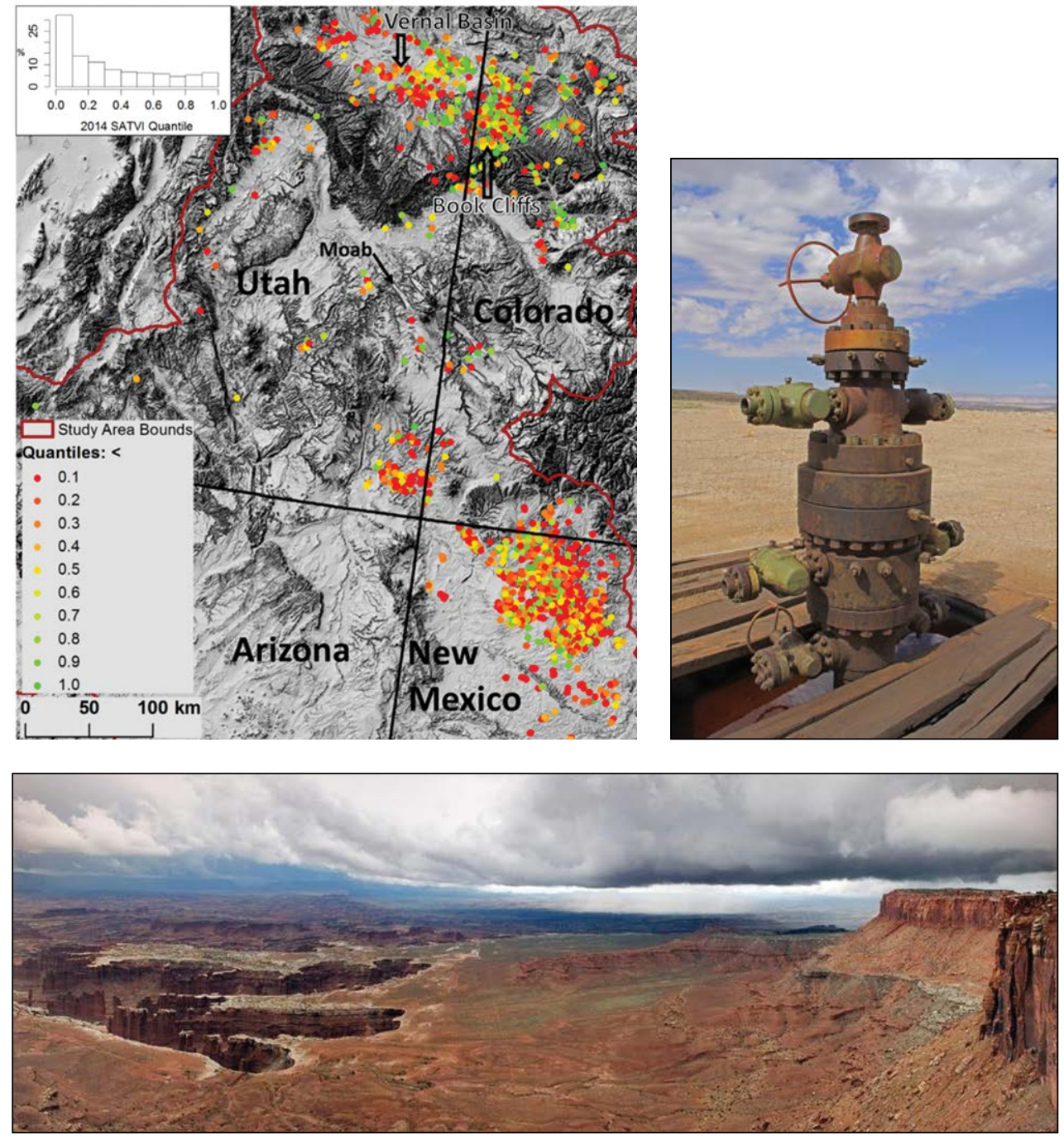

Map at upper left: Spatial distribution and histogram of well-pad recovery quantiles obtained using the disturbance automated reference toolset (DART). Points in red have lower vegetation cover signal and those in green have higher cover relative to reference areas (from Nauman and others, 2017). Upper right photograph: Shut in gas well on Bureau of Land Management lands in Grand County, Utah. Bottom photograph: View from Grand View Point in Canyonlands National Park. 


\section{Informing Energy Development Siting Decisions With Vertebrate Biodiversity Measures}

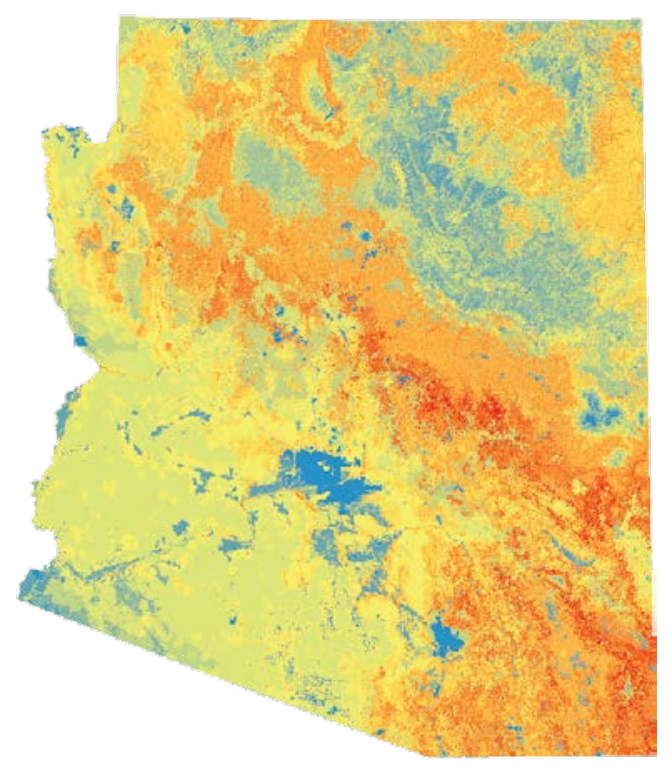

USGS researchers are gathering information about vertebrate biodiversity needed by management agencies in Arizona to inform siting guidance for energy development on public lands. Siting guidance may help managers in identifying potential energy development conflicts with species of conservation concern. Scientists can use watershed-scale range models for vertebrate species developed through the USGS National Gap Analysis Program to illustrate how indices of biodiversity may be incorporated into renewable energy siting decisions.

\section{Contact}

Kathryn Thomas, USGS Southwest Biological Science Center, kathryn_a_thomas@usgs.gov, (520) 670-6671, ext.238

Map at left: Bat species richness in Arizona. The areas with the highest number of species ( 23 species) are shown in red, and the colors range down to the lowest number of species in blue. Image by Kathryn Thomas, U.S. Geological Survey.

\section{Modeling of Cumulative Impacts for Conservation Planning and Renewable Energy Development in the Mojave Desert}

USGS scientists developed analytical approaches, tools, and geospatial data to support conservation planning for renewable energy development in the California deserts. Research focused on geographical analysis to avoid, minimize, and mitigate the cumulative biological effects of utility-scale solar energy development. Researchers collected new data to model cumulative impacts for conservation planning applications. A model was created to map the relative degree of compatibility of new solar energy projects with current biological conservation values. Species distribution models were produced for 65 animal and plant species of potential conservation importance to the DRECP process. These models were used to map both historical and projected future habitat. A spatial decision support tool was created to aid in locating potential sites for offsetting project impacts on the basis of user-supplied conservation criteria. Finally, an analytical framework was designed to assess the potential cumulative impacts of multiple solar energy projects given background climate and land-use change.

\section{Contact}

Jason Kreitler, USGS Western Geographic Science Center, jkreitler@usgs.gov, (208) 426-5217

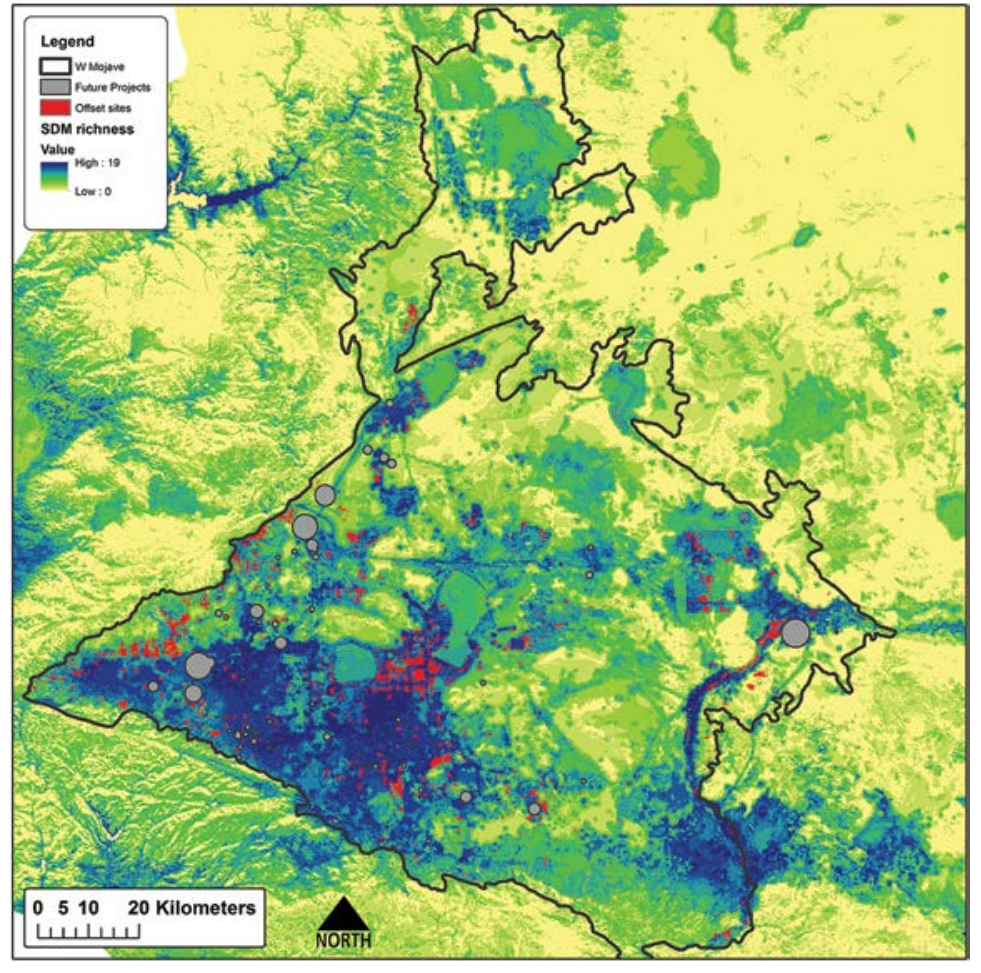

Solar offset map for the Desert Renewable Energy Conservation Plan (from Kreitler and others, 2015). 


\section{Publications}

Moore-O’Leary, K.A., Hernandez, R.R., Johnston, D.S., Abella, S.R., Tanner, K.E., Swanson, A.C., Kreitler, Jason, and Lovich, J.E., 2017, Sustainability of utility-scale solar energy-Ecological concepts: Frontiers in Ecology and the Environment, prepublication early view, https://doi.org/10.1002/fee.1517.

Kreitler, Jason, Schloss, C.A., Soong, Oliver, Hannah, Lee, and Davis, F.W., 2015, Conservation planning for offsetting the impacts of development-A case study of biodiversity and renewable energy in the Mojave Desert: PLOS ONE, v. 10, no. 11, e0140226, https://doi.org/10.1371/journal.pone.0140226.

\section{Energy Futures for Wyoming}

As part of the Wyoming Landscape Conservation Initiative (WLCI), the USGS is mapping the locations and extents of potential electricity-generating resources in Wyoming. This work includes mapping resources, such as natural gas, coal, wind, and hydropower, as well as transmission and transportation corridors. Results of this work can be used to inform the WLCI and other energy-related studies. More broadly, USGS researchers are developing an energy-assessment framework and methods that can be used in other regions.

\section{Contact}

Zachary Bowen, USGS Fort Collins Science Center, bowenz@usgs.gov, (970) 226-9218

\section{Publication}

Bowen, Z.H., Aldridge, C.L., Anderson, P.J., Assal, T.J., Bartos, T.T., Chalfoun, A.D., Chong, G.W., Dematatis, M.K., Eddy-Miller, C.A., Garman, S.L., Germaine, S.S., Homer, C.G., Huber, C.C., Kauffman, M.J., Manier, D.J., Melcher, C.P., Miller, K.A., Norkin, Tamar, Sanders, L.E., Walters, A.W., Wilson, A.B., and Wyckoff, T.B., 2016, U.S. Geological Survey science for the Wyoming Landscape Conservation Initiative-2015 annual report: U.S. Geological Survey Open-File Report 2016-1141, 59 p., https://doi.org/10.3133/ofr20161141.

Biewick, L.R.H., and Wilson, A.B., 2014, Energy map of southwestern Wyoming, Part B-Oil and gas, oil shale, uranium, and solar: U.S. Geological Survey Data Series 843, 20 p., 4 pls., https://doi.org/10.3133/ds843.

Biewick, L.R.H., and Jones, N.R., 2012, Energy map of southwestern Wyoming, Part A-Coal and wind: U.S. Geological Survey Data Series 683, 18 p., 5 pls., https://pubs.usgs.gov/ds/683/.

\section{Geographic Context in Wind Energy Land Transformation}

Land transformation, measured as hectares of surface disturbance per megawatt, associated with wind facilities shows wide variation in its reported values. USGS scientists digitized land transformation at 39 wind facilities by using high-resolution aerial imagery and investigated how turbine size, configuration, land cover, and topography affected the levels of total land transformation. The results indicate that the geographic context in which facilities are installed affects the levels of land transformation associated with wind energy. For example, flat topographies had the lowest land transformation, while facilities on mesas had the largest. This information can assist managers with decisions on how to create opportunities for wind energy production that minimize land-cover change through effective siting. Scientists are now investigating the role of geographic context on road networks and how this affects habitat fragmentation around new facilities.

\section{Contact}

Jay Diffendorfer, USGS Geosciences and Environmental Change Science Center, jediffendorfer@usgs.gov, (303) 236-5369

\section{Publication}

Diffendorfer, J.E., Beston, J.A., Merrill, M.D., Stanton, J.C., Corum, M.D., Loss, S.R., Thogmartin, W.E., Johnson, D.H., Erickson, R.A., and Heist, K.W., 2017, A method to assess the population-level consequences of wind energy on bird and bat species, in Köppel, Johann, ed., Wind Energy and Wildlife Interactions-Presentations from the CWW2015 Conference: New York, Springer, p. 65-78, https://doi.org/10.1007/978-3-319-51272-3_4. 


\section{Additional Publications About Energy Planning Tools}

Dilts, T.E., Weisberg, P.J., Leitner, Philip, Matocq, M.D., Inman, R.D., Nussear, K.E., and Esque, T.C., 2016, Multiscale connectivity and graph theory highlight critical areas for conservation under climate change: Ecological Applications, v. 26, no. 4, p. 1223-1237, https://doi.org/10.1890/15-0925.

Inman, R.D., Esque, T.C., Nussear, K.E., Leitner, Philip, Matocq, M.D., Weisberg, P.J., and Dilts, T.E., 2016, Impacts of climate change and renewable energy development on habitat of an endemic squirrel, Xerospermophilus mohavensis, in the Mojave Desert, U.S.A.: Biological Conservation, v. 200, p. 112-121, https://doi.org/10.1016/j.biocon.2016.05.033.

Zipkin, E.F., Kinlan, B.P., Sussman, Allison, Rypkema, Diana, Wimer, Mark, and O'Connell, A.F., 2015, Statistical guidelines for assessing marine avian hotspots and coldspots - A case study on wind energy development in the U.S. Atlantic Ocean: Biological Conservation, v. 191, November, p. 216-223, https://doi.org/10.1016/j.biocon.2015.06.035.

Esque, T.C., Nussear, K.E., Inman, R.D., Matocq, M.D., Weisberg, P.J., Dilts, T.E., and Leitner, Philip, 2014, Potential habitat modeling, genetics and habitat connectivity for the Mohave ground squirrel to guide Renewable Development, Final project report: Sacramento, Division of Energy Research and Development, California Energy Commission, CEC-500-2014-003, 149 p., http://www.energy.ca.gov/2014publications/CEC-500-2014-003/CEC-500-2014-003.pdf.

Inman, R.D., Nussear, K.E., Esque, T.C., Vandergast, A.G., Hathaway, S.A., Wood, D.A., Barr, K.R., and Fisher, R.N., 2014, Mapping habitat for multiple species in the Desert Southwest: U.S. Geological Survey Open-File Report 2014-1134, 92 p., https://doi.org/10.3133/ofr20141134.

Keinath, Douglas, and Kauffman, Matthew, 2014, Quantifying exposure of Wyoming's wildlife to energy development in the face of expanding production: Prepared by the Wyoming Natural Diversity Database, Laramie Wyoming and Wyoming Cooperative Fish and Wildlife Research Unit for the Wyoming Game and Fish Department, Cheyenne, Wyo., and the U.S. Geological Survey, Fort Collins, Colo., 65 p., http://www.uwyo.edu/wyndd/_files/docs/reports/wynddreports/ u14kei01wyus.pdf.

Inman, R.D., Esque, T.C., Nussear, K.E., Leitner, P., Matocq, M.D., Weisberg, P.J., Dilts, T.E., and Vandergast, A.D., 2013, Is there room for all of us? Renewable energy and Xerospermophilus mohavensis: Endangered Species Research, v. 20, no. 1, p. 1-18, https://doi.org/10.3354/esr00487.

Vangergast, Amy, Inman, Richard, Barr, Kelly, Nussear, Kenneth, Esque, Todd, Hathaway, Stacie, Wood, Dustin, Medica, Philip, Breinholt, Jesse, Stephen, Catherine, Gottscho, Andrew, Marks, Sharyn, Jennings, W., and Fisher, Robert, 2013, Evolutionary hotspots in the Mojave Desert: Diversity v. 5, no. 2, p. 293-319, https://doi.org/10.3390/d5020293.

Wood, D.A., Vandergast, A.G., Barr, K.R., Inman, R.D., Esque, T.C., Nussear, K.E., Fisher, R.N., and Bode, Michael, eds., 2012, Comparative phylogeography reveals deep lineages and regional evolutionary hotspots in the Mojave and Sonoran Deserts: Diversity and Distributions, v. 19, no. 7, p. 722-737, https://doi.org/10.1111/ddi.12022.

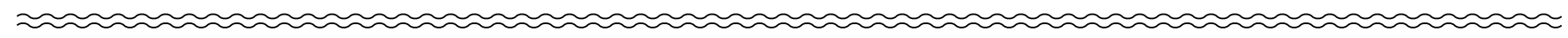




\section{Fatality Estimation Tools}

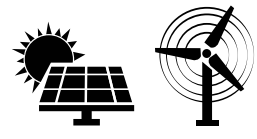

\section{Advances in Estimating Fatalities From Collisions With Energy Infrastructure}

Accurate estimates of bird and bat fatalities from collisions with energy infrastructure can be difficult because carcasses may not be detected or may be scavenged. These estimates, however, are critical to understanding the effects on species populations and devising effective methods to mitigate or minimize deaths. Accurate estimation is complicated because animals killed at facilities may go undetected when carcasses fall outside the search area, are removed by scavengers, or missed by searchers during surveys. The USGS and USFWS are working to develop new tools and improve existing tools to estimate actual bird and bat fatalities based on carcass searches near energy infrastructure. Factors such as fraction of turbines searched, time between searches, searchable area, imperfect carcass detection, and carcass persistence are being evaluated for inclusion. The software may enable resource managers and wind-facility developers to design monitoring protocols that can be optimized for different objectives.

\section{Contact}

Manuela Huso, USGS Forest and Rangeland Ecosystem Science Center, mhuso@usgs.gov, (541) 750-0948

\section{Publications}

Huso, M.M., Dalthorp, D.H., and Korner-Nievergelt, F., 2017, Statistical principles of post-construction fatality monitoring design, chap. 4 in Perrow, Martin, ed., Wildlife and wind farms, conflicts and solutions; offshore-Monitoring and mitigation: Exeter, UK, Pelagic Publishing, 227 p.

Huso, Manuela, Dalthorp, Dan, Miller, T.J., and Bruns, Dawn, 2016, Wind energy development—Methods to assess bird and bat fatality rates post-construction: Human-Wildlife Interactions, v. 10, no. 1, p. 62-70, http://digitalcommons.usu.edu/hwi/vol10/ iss $1 / 8 /$.

Korner-Nievergelt, Fränzi, Behr, Oliver, Brinkmann, Robert, Etterson, M.A., Huso, M.M.P., Dalthorp, Dan, Korner-Nievergelt, Pius, Roth, Tobias, and Niermann, Ivo, 2015, Mortality estimation from carcass searches using the R-package carcass-A tutorial: Wildlife Biology, v. 21, no. 1, p. 30-43, https://doi.org/10.2981/wlb.00094.

Huso, M.M.P., and Dalthorp, Dan, 2014, Accounting for unsearched areas in estimating wind turbine-caused fatality: Journal of Wildlife Management, v. 78, no. 2, p. 347-358, https://doi.org/10.1002/jwmg.663.

\section{Evidence of Absence (version 2.0)}

The USGS developed the "Evidence of Absence" statistical tool for estimating mortality of rare or endangered species where the loss of even one or two individuals may have a negative impact on the population. This tool helps resource managers design monitoring protocols that optimize detection probability at the lowest cost, evaluate whether permitted "take" rate is likely to have been exceeded, and project future take to inform adaptive management. Version 2.0 of "Evidence of Absence" further supports the conservation needs of USFWS by adding modules for (1) estimating searcher efficiency and carcass persistence from user-provided trial data, (2) streamlining the process for analyzing search data, and (3) providing guidance on interpreting data to signal when to initiate adaptive management. A multisession online training program is being developed to provide instruction on the use of the new features. The upgraded tool will help resources managers and wind energy industry representatives, as well as private consultants, respond to habitat conservation plans.

\section{Contact}

Manuela Huso, USGS Forest and Rangeland Ecosystem Science Center, mhuso@usgs.gov, (541) 750-0948

\section{Publications}

Dalthorp, Daniel, Huso, Manuela, and Dail, David, 2017, Evidence of absence (ver. 2.0) software user guide: U.S. Geological Survey Data Series 1055, 109 p., https://doi.org/10.3133/ds1055.

Dalthorp, Daniel, and Huso, Manuela, 2015, A framework for decision points to trigger adaptive management actions in longterm incidental take permits: U.S. Geological Survey Open-File Report 2015-1227, https://doi.org/10.3133/ofr20151227.

Huso, M.M.P., Dalthorp, Dan, Dail, David, and Madsen, Lisa, 2015, Estimating wind-turbine caused bird and bat fatality when zero carcasses are observed: Ecological Applications, v. 25, no. 5, p. 1213-1225, https://doi.org/10.1890/14-0764.1. 


\section{Fatality Monitoring Design and Estimation Software for Solar Power Facilities}

The USGS, in collaboration with USFWS, is providing new methods for monitoring mortality at solar facilities on the basis of current wind-power facilities procedures adapted for unique conditions encountered at solar facilities. Case studies illustrate how distance-sampling techniques may improve overall detectability without substantially increasing monitoring costs. In addition, the USGS is modifying existing mortality estimation to produce unbiased estimates of fatalities and develop "Evidence of Absence" software for rare species at solar facilities. The approach accounts for searcher efficiency and carcass persistence as well as different sources of fatality at solar facilities. The software can assist the USFWS and the BLM, on whose lands much solar development is taking place, to analyze data on the effects of solar facilities on migratory bird mortality and on potential impacts to protected species.

\section{Contact}

Manuela Huso, USGS Forest and Rangeland Ecosystem Science Center, mhuso@usgs.gov, (541) 750-0948

\section{Publication}

Huso, Manuela, Dietsch, Thomas, and Nicolai, Chris, 2016, Mortality monitoring design for utility-scale solar power facilities: U.S. Geological Survey Open-File Report 2016-1087, 44 p., https://doi.org/10.3133/ofr20161087.
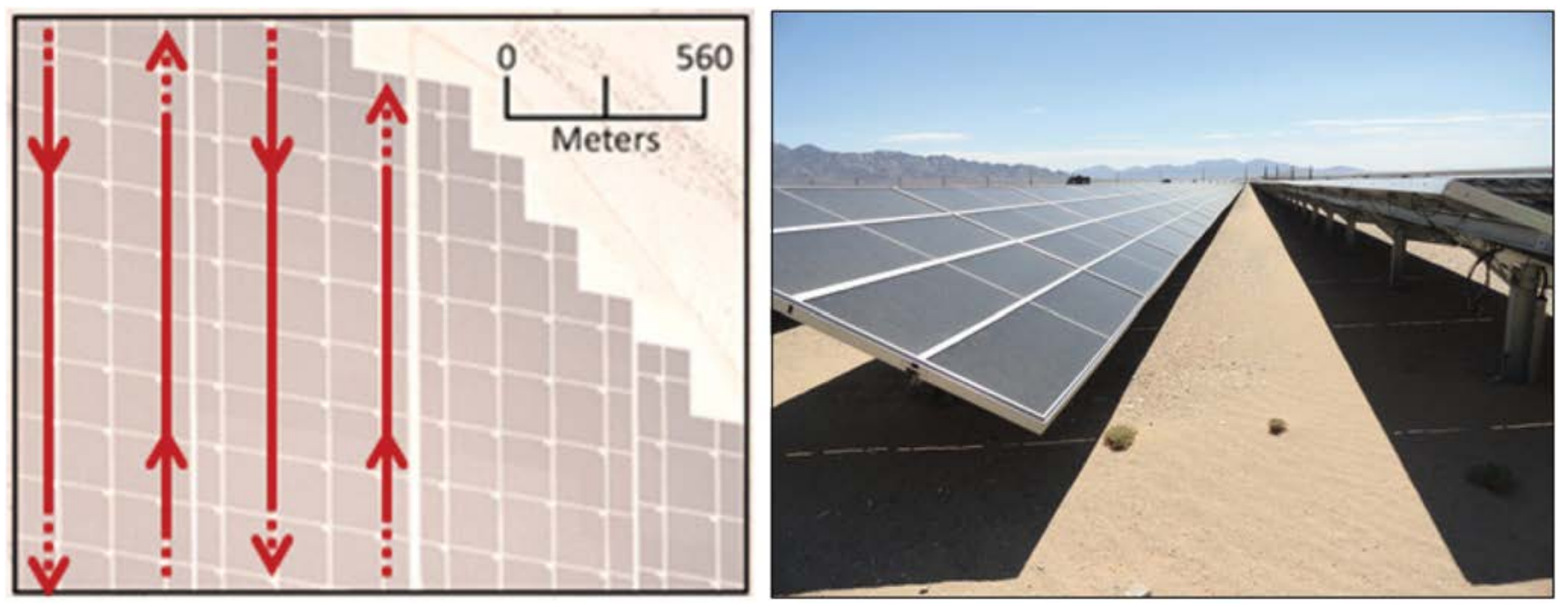

Transect pattern within photovoltaic panel array (from Huso and others, 2016).

\section{Additional Publications About Fatality Estimation}

Johnson, D.H., Loss, S.R., Smallwood, K.S., and Erickson, W.P., 2016, Avian fatalities at wind energy facilities in North America-A comparison of recent approaches: Human-Wildlife Interactions, v. 10, no. 1, p. 7-18, http://digitalcommons.usu.edu/hwi/vol10/iss1/3/.

Péron, Guillaume, Hines, J.E., Nichols, J.D., Kendall, W.L., Peters, K.A., Mizrahi, D.S., and Matthiopoulos, Jason, eds., 2013, Estimation of bird and bat mortality at wind-power farms with superpopulation models: Journal of Applied Ecology, v. 50, no. 4, p. 902-911, https://doi.org/10.1111/1365-2664.12100. 


\section{Risk Assessment and Management Support Tools}

\section{Understand Risks}

\section{Onshore Industrial Wind Turbine Locations}

The USGS updated a national dataset of onshore, industry-scale wind turbines in the United States through March 2014. Turbine locations were obtained from the Federal Aviation Administration (FAA) Digital Obstacle File; data are digitized and spatially verified. Turbines without FAA Obstacle Repository System numbers were obtained from publicly available facility datasets and were visually identified; point locations were added to the collection. Turbine position was verified using highresolution aerial imagery with a final locational error of less than 10 meters (33 feet). Technical specifications, such as height, blade length, rotor swept area,

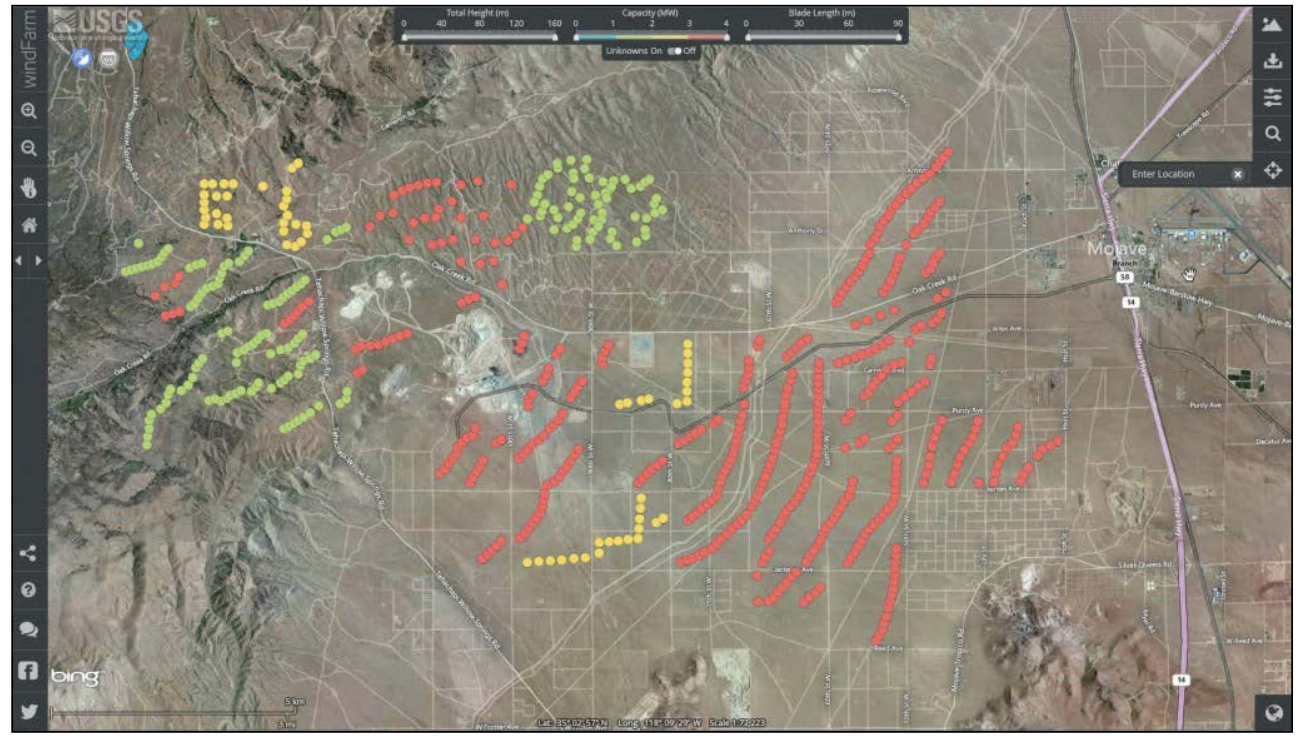

A screenshot from the USGS WindFarm mapping application showing locations and types of turbines in southern California. model, and size, were attributed for the majority of turbines on the basis of a variety of sources. This map of onshore commercial scale wind turbines can assist scientists, regulatory agencies, nongovernmental organizations, and other decision makers in more easily assessing and planning for the effects of wind energy development on federally protected species.

\section{Contact}

Jay Diffendorfer, USGS Geosciences and Environmental Change Science Center, jediffendorfer@usgs.gov, (303) 236-5369

\section{Publication}

Diffendorfer, J.E., Compton, Roger, Kramer, Louisa, Ancona, Zach, and Norton, Donna, 2014, Onshore industrial wind turbine locations for the United States through July 2013 (ver. 1.2, January 2017): U.S. Geological Survey Data Series 817, https://doi.org/10.3133/ds817.

\section{Bird and Bat Risk From Wind Development}

The USGS partnered with numerous nongovernmental and academic organizations in summarizing studies of raptor interactions with wind energy facilities from around the world, including case studies from Spain, Norway, Canada, United States, and southern Africa. Scientists also examined current pre-construction assessment risks to wildlife from wind turbines. Several shortcomings in methods used to assess the risk of fatality at turbines were noted, including the dearth of studies to offer evidence for an association between pre-construction surveys and post-construction fatality.

\section{Contact}

Todd Katzner, USGS Forest and Rangeland Ecosystem Science Center, tkatzner@usgs.gov, (208) 426-5232 


\section{Publications}

Watson, R.T., Kolar, P.S., Ferrer, Miguel, Nygård, Torgeir, Johnston, Naira, Hunt, W.G., Smit-Robinson, H.A., Farmer, Christopher, Huso, Manuela, and Katzner, Todd, in press, Raptor interactions with wind energy - Case studies from around the world: Journal of Raptor Research.

Katzner, Todd, Bennett, Victoria, Miller, Tricia, Duerr, Adam, Braham, Melissa, and Hale, Amanda, 2016, Wind energy development-Methods for assessing risks to birds and bats pre-construction: Human-Wildlife Interactions, v. 10, no. 1, p. 42-52, http://digitalcommons.usu.edu/hwi/vol10/iss1/6/.

\section{Measure Impacts}

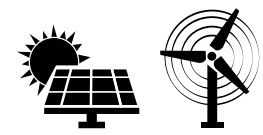

\section{Advancing Wildlife Monitoring Technologies at Wind and Solar Facilities}

USGS research in aeroecology relies on advancing radar and other kinds of remote sensing technology to understand the behavior and ecology of flying animals, especially in relation to new energy generation infrastructure. The USGS is using both historical and traditional technologies to observe wildlife behaviors in response to these changing habitats. In regions developing wind power, radar and thermal imagery are used to study bird and bat behavior in ways that contribute to the conservation and management of these species. USGS research has also expanded to examine how birds and bats respond to large-scale solar energy facilities, such as the Ivanpah Solar Electric Generating System facility in southern California. By working with the solar industry and other partners, the USGS is developing ways to mitigate the impacts on wildlife and preserve the ecological services and economic benefits provided by these animals. (For more information: https://www.usgs.gov/ centers/norock/science-topics/aeroecology)

\section{Contact}

Robb Diehl, USGS Northern Rocky Mountain Science Center, rhdiehl@usgs.gov, (406) 994-7481

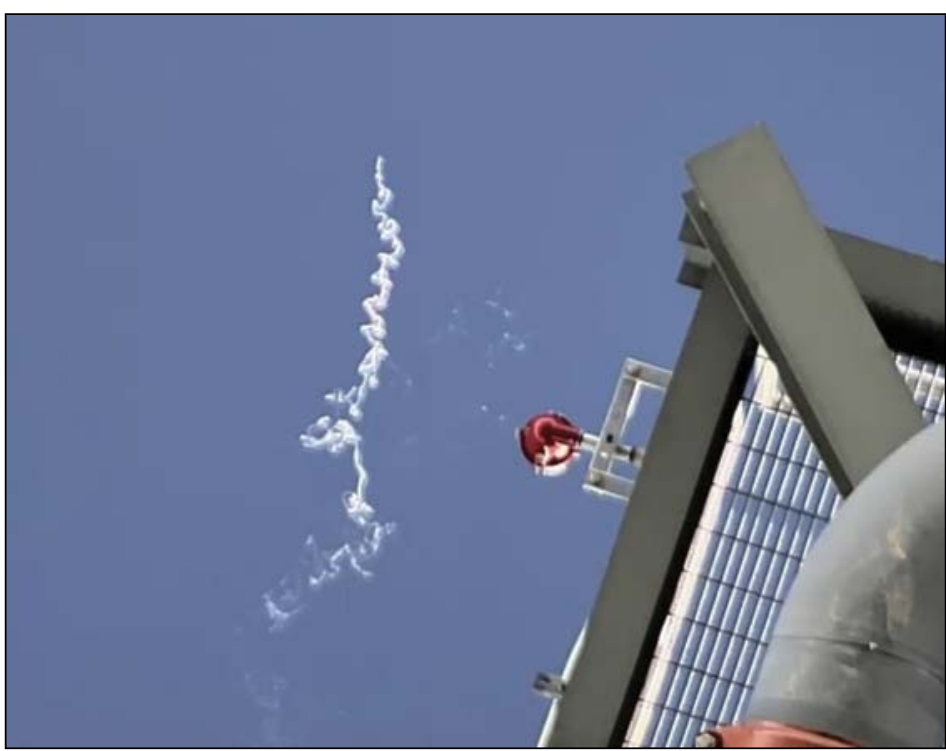

Erratic flight of insect burning in a solar flux field produced by a solar tower facility in the Mojave Desert, California (from Diehl and others, 2016).

\section{Publication}

Diehl, R.H., Valdez, E.W., Preston, T.M., Wellik, M.J., Cryan, P.M., and Mousseau, T.A., ed., 2016, Evaluating the effectiveness of wildlife detection and observation technologies at a solar power tower facility: PLOS ONE, v. 11, no. 7, e0158115, https://doi.org/10.1371/journal.pone.0158115.

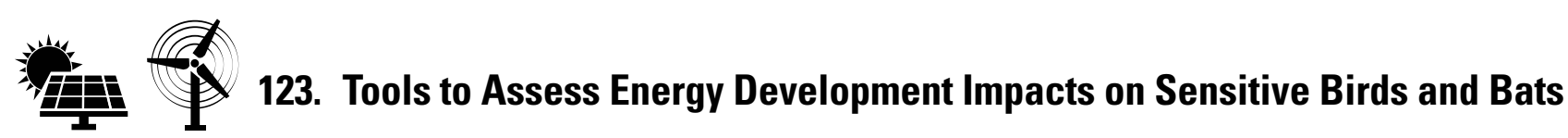

A combination of tools is being used to understand how mortality at renewable energy facilities affects populations of sensitive bird and bat species in California. As part of this project, stable isotopes are being used to estimate the geographic scope of the population of birds or bats affected, and demographic modeling can forecast how individual fatalities affect the growth or decline of the species' populations. Development of analytical methods can aid in determining the best practices for conducting risk assessments and predicting mitigation outcomes. Field surveys design and protocols are also being developed and integrated with the developed tools. These tools can allow energy developers to more accurately estimate fatality rates and effects of mitigation techniques at wind and solar energy facilities, which may streamline permitting and ultimately reduce costs of energy development. 


\section{Contacts}

Manuela Huso, USGS Forest and Rangeland Ecosystem Science Center, mhuso@usgs.gov, (541) 750-0948

Todd Katzner, USGS Forest and Rangeland Ecosystem Science Center, tkatzner@usgs.gov, (208) 426-5232

\section{Publication}

Katzner, T.E., Nelson, D.M., Braham, M.A., Doyle, J.M., Fernandez, N.B., Duerr, A.E., Bloom, P.H., Fitzpatrick, M.C., Miller, T.A., Culver, R.C.E., Braswell, Loan, and DeWoody, J.A., 2017, Golden eagle fatalities and the continental-scale consequences of local wind-energy generation: Conservation Biology, v. 31, no. 2, p. 406-415, https://doi.org/10.1111/ cobi.12836.

\section{Detecting Population-Level Impacts of Wind Energy Development}

The impact of wind energy generation on wildlife is commonly approached by monitoring the incidence of mortality resulting from turbine collisions. These mortality events may or may not scale up to observable impacts at a population level. USGS scientists are developing a framework for assessing population-level impacts of wind energy by using abundance timeseries data and turbine location maps. The two-part approach first examines whether the timing and placement of turbines on the landscape are coincident with observed population trends at regional scales by using dynamic factor analysis. Next, localized impacts are examined by comparing population trends from sampling locations in close proximity to wind turbine development with relatively distant locations by using Bayesian structural time-series models. This research can assist conservation managers with wind energy project permitting and the use and interpretation of monitoring protocols for wind facilities.

\section{Contact}

Wayne Thogmartin, USGS Upper Midwest Environmental Sciences Center, wthogmartin@usgs.gov, (608) 781-6309

\section{Publications}

Diffendorfer, J.E., Beston, J.A., Merrill, M.D., Stanton, J.C., Corum, M.D., Loss, S.R., Thogmartin, W.E., Johnson, D.H., Erickson, R.A., and Heist, K.W., 2017, A method to assess the population-level consequences of wind energy on bird and bat species, in Köppel, Johann, ed., Wind Energy and Wildlife Interactions-Presentations from the CWW2015 Conference: New York, Springer, p. 65-76, https://doi.org/10.1007/978-3-319-51272-3_4.

Erickson, R.A., Thogmartin, W.E., Diffendorfer, J.E., Russell, R.E., and Szymanski, J.A., 2016, The synergistic effects of wind energy generation and white-nose syndrome threaten the extinction of the endangered Indiana bat: PeerJ, v. 4, e2830, https://doi.org/10.7717/peerj.2830.

\section{Wind Energy Impacts Assessment Method}

USGS scientists developed a method for evaluating national to regional impacts of wind energy on bats and birds. The method focuses primarily on the effects of collisions between wildlife and turbines. Primary uses of this method, which is complementary to and incorporates detailed studies and demographic models on key species, include (1) quantitative measuring of the potential impacts to species' populations through demographic modeling and the use of potential biologic removal methods; (2) ranking species in terms of their direct and indirect relative risk to wind energy development; (3) suggesting species for more intensive demographic modeling or study; and (4) highlighting species for which the effects of wind energy development on their populations are projected to be small. This method can be used to evaluate species for more or less intensive demographic modeling based on the projected impacts from wind energy development on the populations of the species.

\section{Contact}

Jay Diffendorfer, USGS Geosciences and Environmental Change Science Center, jediffendorfer@usgs.gov, (303) 236-5369

\section{Publications}

Diffendorfer, J.E., Beston, J.A., Merrill, M.D., Stanton, J.C., Corum, M.D., Loss, S.R., Thogmartin, W.E., Johnson, D.H., Erickson, R.A., and Heist., K.W., 2017, A method to assess the population-level consequences of wind energy on bird and bat species, in Köppel, Johann, ed., Wind Energy and Wildlife Interactions-Presentations from the CWW2015 Conference: New York, Springer, p. 65-76, https://doi.org/10.1007/978-3-319-51272-3_4. 
Haider, H.S., Oldfield, S.C., Tu, Tiffany, Moreno, R.K, Diffendorfer, J.E., Eager, E.A., and Erickson, R.A., 2017, Incorporating Allee effects into the potential biological removal level: Natural Resource Modeling, prepublication early view, e12133, https://doi.org/10.1111/nrm.12133.

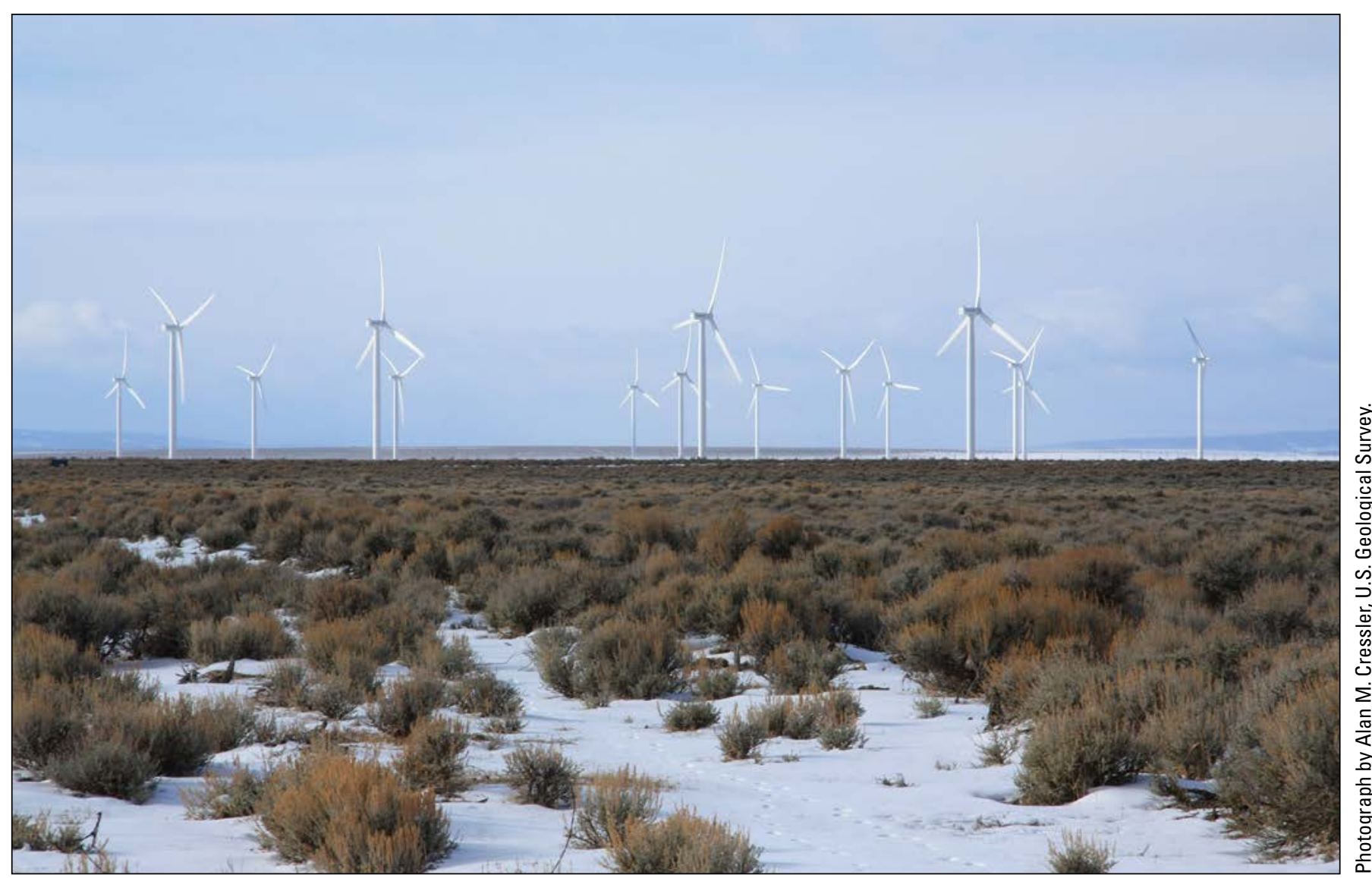

Wind farm in Uinta County, Wyoming. 


\section{References Cited}

American Wind Energy Association, 2017, U.S. Wind Industry first quarter 2017 market report, AWEA public version: [Washington, D.C.], American Wind Energy Association Data Services, accessed July 5, 2017, at http://awea.files.cms-plus.com/FileDownloads/pdfs/1Q2017\%20AWEA\%20Market\%20Report\%20Public\%20Version.pdf.

Cullinane Thomas, Catherine, and Koontz, Lynne, 2017, 2016 National park visitor spending effects-Economic contributions to local communities, States, and the Nation: National Park Service, Natural Resource Report NPS/NRSS/EQD/NRR2017/1421, 38 p., accessed July 6, 2017, at https://www.nps.gov/nature/customcf/NPS_Data_Visualization/docs/ 2016_VSE.pdf.

Dennerline, D.E., and Childs, D.E., eds., 2017, U.S. Geological Survey Cooperative Fish and Wildlife Research Units Program-2016-2017 research abstracts (ver. 1.1, May 2017): U.S. Geological Survey Circular 1427, 164 p., accessed July 10, 2017, at https://doi.org/10.3133/cir1427.

U.S. Energy Information Administration [EIA], 2016, International Energy Outlook 2016: Washington, D.C., U.S. Energy Information Administration, DOE/EIA-0484(2016), 276 p., accessed July 14, 2016, at https:/www.eia.gov/outlooks/ieo/pdf/ 0484(2016).pdf.

U.S. Energy Information Administration [EIA], 2017a, United States remains the world's top producer of petroleum and natural gas hydrocarbons: U.S. Energy Information Administration web page, accessed July 14, 2017, at https://www.eia.gov/ todayinenergy/detail.php?id=31532.

U.S. Energy Information Administration [EIA], 2017b, U.S. electric generating capacity increase in 2016 was largest net change since 2011: U.S. Energy Information Administration web page, accessed July 14, 2017, at https://www.eia.gov/todayinenergy/ detail.php?id=30112. 


\section{List of Species}

\begin{tabular}{|c|c|}
\hline Common name & Scientific name \\
\hline Agassiz's desert tortoise/desert tortoise & Gopherus agassizii \\
\hline Agave & Agave Americana \\
\hline American eel & Anguilla rostrata \\
\hline American shad & Alosa sapidissima \\
\hline Ashy storm-petrel & Oceanodroma homochroa \\
\hline Atlantic roseate tern & Sterna dougallii \\
\hline Atlantic sturgeon & Acipenser oxyrinchus oxyrinchus \\
\hline Bald eagle & Haliaeetus leucocephalus \\
\hline Black brant goose & Branta bernicla nigricans \\
\hline Black scoter & Melanitta nigra \\
\hline Black storm-petrel & Oceanodroma melania \\
\hline Bobcat & Lynx rufus \\
\hline Brewer's sparrow & Spizella breweri \\
\hline Brook trout & Salvelinus fontinalis \\
\hline Brown pelican & Pelecanus occidentalis \\
\hline Bull trout & Salvelinus confluentus \\
\hline California condor & Gymnogyps californianus \\
\hline Chinook salmon & Oncorhynchus tshawytscha \\
\hline Coho salmon & Oncorhynchus kisutch \\
\hline Common loon & Gavia immer \\
\hline Common merganser & Mergus merganser \\
\hline Duckweed & Lemna minor \\
\hline Eastern red bat & Lasiurus borealis \\
\hline Elegant tern & Thalasseus elegans \\
\hline Fathead minnow & Pimephales promelas \\
\hline Ferruginous hawk & Buteo regalis \\
\hline Florida manatee & Trichechus manatus latirostris \\
\hline Giant kelp & Macrocystis pyrifera \\
\hline Golden eagle & Aquila chrysaetos \\
\hline Graham's beardtongue & Penstemon grahamii \\
\hline Greater sage-grouse & Centrocercus urophasianus \\
\hline Greater scaup & Aythya marila \\
\hline Greater white-fronted goose & Anser albifrons \\
\hline Green sea turtle & Chelonia mydas \\
\hline Green sunfish & Lepomis cyanellus \\
\hline Gulf sturgeon & Acipenser oxyrinchus \\
\hline Hardstem bulrush & Schoenoplectus acutus \\
\hline Hawaiian hoary bat & Lasiurus cinereus semotus \\
\hline Hawaiian petrel & Pterodroma sandwichensis \\
\hline Hoary bat & Lasiurus cinereus \\
\hline
\end{tabular}




\section{List of Species - Continued}

\begin{tabular}{|c|c|}
\hline Common name & Scientific name \\
\hline Honey bee & Apis mellifera \\
\hline Horned grebe & Podiceps auritus \\
\hline Horned lark & Eremophila alpestris \\
\hline Humpback chub & Gila cypha \\
\hline Indiana bat & Myotis sodalis \\
\hline Jones cycladenia & Cycladenia humilis var. jonesii \\
\hline Kemp's ridley & Lepidochelys kempii \\
\hline Lesser prairie-chicken & Tympanuchus pallidicinctus \\
\hline Lesser scaup & Aythya affinis \\
\hline Loggerhead & Caretta caretta \\
\hline Long-tailed duck & Clangula hyemalis \\
\hline Monarch butterfly & Danaus plexippus \\
\hline Mule deer & Odocoileus hemionus \\
\hline Musk thistle & Carduus nutans \\
\hline Newell's shearwater & Puffinus newelli \\
\hline Northern gannet & Morus bassanus \\
\hline Northern harrier & Circus cyaneus \\
\hline Northern leopard frog & Lithobates pipiens \\
\hline Northern long-eared bat & Myotis septentrionalis \\
\hline Pacific walrus & Odobenus rosmarus divergens \\
\hline Polar bear & Ursus maritimus \\
\hline Prairie falcon & Falco mexicanus \\
\hline Rainbow trout & Oncorhynchus mykiss \\
\hline Razorback sucker & Xyrauchen texanus \\
\hline Red-breasted merganser & Mergus serrator \\
\hline Red-necked grebe & Podiceps grisegena \\
\hline Red-throated loon & Gavia stellata \\
\hline Sagebrush sparrow & Artemisiospiza nevadensis \\
\hline Sage thrasher & Oreoscoptes montanus \\
\hline Scripps's murrelet & Synthliboramphus scrippsi \\
\hline Sea lamprey & Petromyzon marinus \\
\hline Sea otter & Enhydra lutris \\
\hline Sooty shearwater & Ardenna grisea \\
\hline Steelhead & Oncorhynchus mykiss \\
\hline Surf scoter & Melanitta perspicillata \\
\hline Swainson's hawk & Buteo swainsoni \\
\hline Swift fox & Vulpes velox \\
\hline Uinta Basin hookless cactus & Sclerocactus wetlandicus \\
\hline West Indian manatee & Trichechus manatus \\
\hline Westslope cutthroat trout & Oncorhynchus clarki lewisi \\
\hline White-winged scoter & Melanitta deglandi \\
\hline
\end{tabular}



Manuscript was approved on August 15, 2017

For additional information regarding this publication, please contact: Mona Khalil mkhali@@usgs.gov

Or visit the USGS Energy and Wildlife Program https://www2.usgs.gov/ecosystems/energy_wildlife

Prepared by the USGS Science Publishing Network Reston and Rolla Publishing Service Centers

Edited by Kay P. Naugle and Stokely J. Klasovsky Layout by Suzanne C. Roberts 


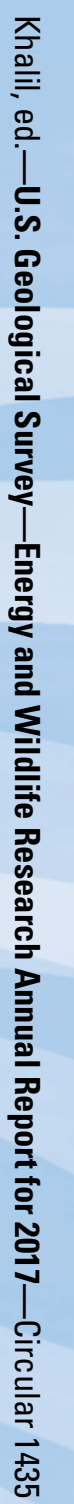

